\title{
Culture Unbound Vol. 12 Editorial
}

\author{
By Johanna Dahlin, Jesper Olsson, Egle Rindzeviciute, \\ Victoria Van Orden Martínez \& Kristin Wagrell
}

At the time of writing, it is April 2020 and large parts of the world are in various stages of Corona-lockdown. Both the severity of the penetration of the virus itself as well as the severity of the measures to combat it varies across the globe, but increasingly everywhere lives are turned upside down. Normality is suspended and it is frequently pronounced that the world will not look the same on the other side of this crisis.

While we are launching a new volume, the current situation also gives renewed actuality to some of our previous publications. Not least, one of our 2016 issues is worth revisiting: Rupture and Exile: Permanent Liminality in Spaces for Movement and Abandonment, edited by Harmony Siganporia and Frank G. Karioris (Volume 8 , issue 1).

This thematic section is centred on liminality, a concept with which every sociocultural anthropologist and many other social and cultural theorists are well acquainted. Liminality is a concept that is most usually attributed to Arnold van Gennep (1873-1957) and his Les Rites de Passage (1909), but it is also tightly associated with Victor Turner and his The Forest of Symbols (1967) or (perhaps especially) The Ritual Process (1969). While Turner departed from a discussion of liminality as primarily an attribute of rites of passage, he also expanded the concept to include "a greater variety of ambiguous situations, epochs, and spaces that might be read as liminal" (Siganporia \& Karioris 2016).

Van Gennep had a three-stage model of rites of passage: separation, margin/ liminality and reintegration. It is in this middle stage we find liminality. Liminality is from Latin limen meaning threshold. It is the boundary between the outside and the inside, between two entities that are separated from one another. A rite of passage is a transition from something old to something new, and liminality is the state of neither nor in between the old and the new. In the case of initiation rites-neither child nor adult. Liminality is marked by ambiguity, uncertainty

Dahlin, Johanna, Jesper Olsson, Egle Rindzeviciute, Victoria Van Orden Martínez \& Kristin Wagrell: "Culture Unbound Vol. 12 Editorial”, Culture Unbound, Volume 12, issue 1, 2020: i-v. Published by Linköping University Electronic Press:

http://www.cultureunbound.ep.liu.se 
and, quite often, physical isolation. Turner described it as a state of being "betwixt and between". The liminal state is ambiguous and indeterminate. It is, he suggests, a "moment in and out of time", and outside "secular social structure" (Turner 1969: 95-96).

Liminality is also characterised by what Turner termed communitas-a deep sense of community outside of normal society and everyday life. It is a recognition "of a generalized social bond" (1969: 96) and springs from the directness of the suspension of normality. In the current pandemic, there are frequent appeals to community and solidarity. Despite physical isolation, there are countless adaptations on "together apart" across the globe. In so many contexts, there is a frequent repetition that "we're in this together". New and old media are filled with examples of how people come together-albeit at a distance.

However, while liminality, according to Turner, is characterized by an erasure of status differences or even their reversal, this ritual equality of liminal states frequently serves to highlight the status differences of ordinary life (his theory is dialectical and structuralist). In contrast, the current pandemic is rife with inequality. It is easier to go into "self-isolation" in a big house with a garden than in a small, and perhaps cramped flat. How isolated isolation is also varies, and to be able to go into isolation at all is a privilege, or a curse. Do you have a job where you can work from a distance-or did you just lose your job because of the crisis? Or do you even have access to clean water to wash your hands? We might be in this together, but we're not in it on equal terms.

While ritual liminality is predetermined in length, many wonder for how long the present situation will drag on. And this is where we return to the thematic issue we're revisiting. In Rupture and Exile, contributions looked at examples where liminality extended toward permanence. Building on, for instance, the work of Arpad Szakolczai and Björn Thomassen, they suggest people and places may become trapped in a form of 'permanent liminality'. Szalkolczai uses a three-stage framework, mirroring that of rites of passage, and suggests that any of these stages can be 'frozen' in which case liminality extends towards permanence. Frozen this way, as Bjørn Thomassen (2012) has suggested, liminality becomes "pure danger".

In Rupture and Exile, the contributors expand on Szakolczais first stage of 'separation' by introducing the notion of rupture: "a breach, or even a clean break from the orientations and grand narratives which undergird societies" (Siganporia \& Karioris 2016: 21). The contributions to the section analyse, with rich empirical detail, reasons for, and the nature of, ruptures which force individuals or groups into liminality in various contexts.

Rupture seems like a particularly apt term to describe what is happening when a tiny virus makes the machine of global capitalism if not grind to halt then at least appear significantly less well greased. Something that has meant the indefinite suspension for so many things that were previously taken for granted. 
At the time of writing, we do not know for how long normality will be suspended. Are we nearing the end or just beginning? And to what extent will the new normal resemble the old? For how long will we live with the consequences? Will we remember this as a period of isolation or community? We are hoping that Culture Unbound will be one of the fora where this conversation can be kept going, and that we will see sharp analysis of the social and cultural consequences of the pandemic appearing in the journal.

Culture Unbound began the year 2019 with a workshop on Interdisciplinarity, publishing and new models of collectivity. This workshop departed from the the idea that the pressure that environmental change puts on previously separate disciplinary knowledges to come together, as it requires a radical rethinking of the way we conduct scholarship. That existing modes of research creation need to be rethought is particularly true in disciplines where the scholar traditionally has been engaged for many years in a project with single authorship. The urgency of environmental change calls for new models of collectivity, and new platforms for collaborative research that are global in scope and agile in relation to changing events and technologies. Now, a year later we may add that the current pandemic is putting this in even sharper relief. If isolation temporarily pushes the scholar back to the Ivory tower, this is paralleled by signs of communitas and calls for collectivity.

Last year was concluded by a celebration of our $10^{\text {th }}$ anniversary with the workshop Publishing, Property and Academic Labour. With talks by Björn Hammarfelt, Janneke Adema and Alessandro Ludovico, the workshop explored the infrastructural challenges in the intersection of scholarly publishing, intellectual property and academic labour. Its purpose was to reflect on the current conditions of scholarly publishing and to initiate a discussion on what the future might hold for journals such as Culture Unbound. We are hoping to continue this discussion and are welcoming any interventions to take these themes further.

For the journal, the year 2020 is also a year of transition. The anniversary constituted a changing of the guards as the old editorial team of Eva Hemmungs Wirtén, James Meese and Johanna Dahlin left the journal to be replaced by Jesper Olsson as editor in chief, Egle Rindzeviciute as associate editor and Kristin Wagrell as executive editor. We also have a new editorial assistant in Victoria Van Orden Martínez. In addition, the 10-year celebration hosted the inaugural meeting of the journal's new editorial board: Marit Ruge Bjærke, Giacomo Botta, Johanna Dahlin, Solveig Daugaard, Per Israelsson, Matts Lindström, Sanna Nyqvist, Carsten Stage, Ingrid Tolstad.

While times may be uncertain, Culture Unbound enters its second decade and remains a truly accessible home for cutting-edge cultural research. 
Johanna Dahlin is leaving the role as executive editor for Culture Unbound after five years, but will remain in the journal's editorial board. She has a background in social anthropology and is assistant professor at Linköping University and currently working on issues relating to the intellectual property of forced labour. E-mail: johanna.dahlin@liu.se

Jesper Olsson is editor in chief of Culture Unbound and Professor at the Department of Culture and Society (IKOS), Linköping University, where he leads the research group Literature, Media History, and Information Cultures (LMI). His research focuses on literature, art, and media ecology, and he is currently writing on weird ecologies in literature and on fish(ing). E-mail: jesper.olsson@ liu.se

Egle Rindzeviciute is associate editor of Culture Unbound. She is Associate Professor of criminology and sociology at Kingston University. Her latest book The Power of Systems: How Policy Sciences Opened Up the Cold War World (2016) explores the role of systems thinking and computer technologies in the construction of global governance. E-mail: e.rindzeviciute@kingston.ac.uk

Victoria Van Orden Martínez is editorial assistant of Culture Unbound. Van Orden Martinez is a $\mathrm{PhD}$ candidate in history at Linköping University in Sweden. She has researched and published articles on the experiences, lives and, in some cases, untimely deaths of Holocaust and concentration camp survivors who came to Sweden as refugees. Her doctoral thesis is tentatively titled "Afterlives: Histories of Women Concentration Camp Survivors in Sweden”. E-mail: cu@isak.liu.se

Kristin Wagrell is executive editor of Culture Unbound. Wagrell recently received her PhD in cultural studies from Tema Q, Linköping University and is currently involved in research on migration and digital heritage. Her research interests span subjects such as Holocaust memory, archives and knowledge construction, and genealogy as method. The title of her doctoral thesis is "Chorus of the Saved": Constructing the Holocaust Survivor in Swedish Public Discourse, 1943-1966". E-mail: cu@isak.liu.se 


\section{References}

Siganporia, H., \& Karioris, F. G. (2016): 'Rupture and exile: Permanent liminality in spaces for movement and abandonment', Culture Unbound, 8(1), 20-25.

Szakolczai, Arpad (2009): 'Liminality and Experience: Structuring transitory situations and trans- formative events', International Political Anthropology Vol. 2, No. 1, 2009.

Thomassen, Bjørn (2012): 'Revisiting liminality: The danger of empty spaces', Hazel Andrews \& Les Roberts (eds): Liminal Landscapes: Travel, Experience, and Spaces in-between, London: Routledge

Turner, Victor (1969): The Ritual Process: Structure and Anti-Structure. Hawthorne: Aldine de Gruyter.

Turner, Victor (1967): The Forest of Symbols: Aspects of Ndembu Ritual. Ithaca, NY. Cornell University Press. 


\title{
Introduction: Archive and Method(s)
}

\author{
By \\ Mattias Frihammar
}

I am writing this introduction in October 2019. From time to time, I rest my eyes on a picture that is pinned to the wall by my desk. It is a photo depicting the twentieth-century photographer Gunnar Lundh. He is standing in a garden, touching a blue flower, a lupine. The wide cuffs of his grey jacket, the hat model and something about the colour palette tell me that it is a photograph shot in the 1940s. The sun is shining, he directs his gaze straight into the camera. When I look at him, he looks back and, despite the time span, our eyes meet. The photograph makes it possible for me to encounter the past.

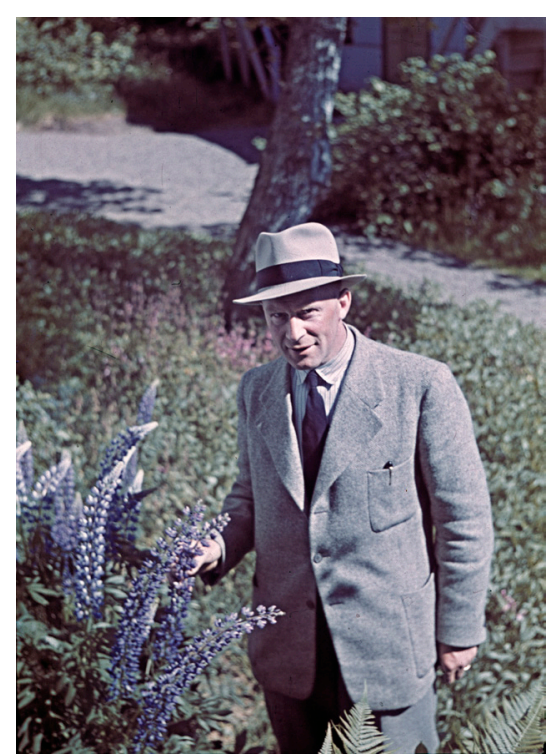

Fig. 1. A photograph of the photographer found in his own archive. Even though the label says "Photo: Lundh, Gunnar", we don't know who was actually holding the camera (NMA.0061944).

Frihammar, Mattias: "Introduction: Archive and Method(s)", Culture Unbound, Volume 12, issue 1, 2020: 1-15. Published by Linköping University Electronic Press: http://www.cultureunbound.ep.liu.se 
When you, valued reader, read this text, you will be able to look at the same photo and meet the gaze of Gunnar Lundh in the same way. From my perspective, this will happen in the future. Perhaps you, as I, get a feeling of meeting the past, looking the photographer of bygone times in the eyes. Possibly you will even get a double image of the past, thinking both of me sitting in my office writing this, and of Gunnar Lundh posing by the lupines in the 1940s. The photograph becomes a time-dissolving point of contact, connecting you, me, and Lundh for a moment.

\section{Pictures of the Past}

This themed issue of Culture Unbound is about ways to get to know past times through pictures and documents. More precisely, the purpose is to explore and develop ethnological and cultural historical methods for research in folklore archives, with special attention paid to photographs as source material. To fulfil this purpose systematically, the concept of "method" has been stretched along three branches. First, method has been understood as a series of steps to approach, handle and understand the archive as an infrastructure of knowledge. How should a researcher navigate, both practically and intellectually, to get into the archive? Secondly, method has been applied as a series of steps to analyse and interpret the fragments, pieces and sections in the archive as sources to information of the past and present. When in the archive, how can the researcher bring the different sources to speak? Finally, method has been conceptualised as a series of steps to connect the knowledge in the archive with other forms of knowledge in academia and society. How can a researcher evaluate and use the knowledge produced in, and by, the archive? All three branches are touched upon in each article, some in greater depth than others.

The national context is Sweden. A great deal is known about the history of the Swedish folklore archives, their scientific background and the research that has used folklore archive sources (Bringéus 1988, Nilsson 1996, Snellman 2010, Nagel 2012, Gustavsson 2014, Nystrand von Unge 2019). While giving this body of scholarly works its due credit, much of the research has focused on the historical background of the archives and the history of the collections (with some exceptions, see Klein 2003, Silvén 2004, Thor Tureby \& Johansson 2017). We will focus instead on methodological issues. The contributors will discuss topics such as political bias built into archives, how new groups can be made visible and researchable in the collections and how it is possible to ask new questions of old source materials.

Historical processes are multileveled in their temporality (Koselleck 2004). This becomes evident when using photographs as sources in historical research, as in the opening chronological exercise with the photo depicting Lundh by the 
lupines. In that example, the past, the present and the future were more than separated dots on a time line. Rather, the time layers occurred as different surfaces of the same prism, breaking the view in several angles: every time layer was mixed with reflections of the others. Gunnar Lund was posing in front of the camera on one occasion, I am writing about it on another, and you will be reading on a third: past, present and future at the same time.

To meet the epistemological challenge of simultaneously analysing several layers of time at once, the researchers in this issue depart from ethnological or folkloristic standpoints; positions that include an outspoken self-reflective approach (Sandberg \& Jespersen 2017: 7ff). Recognising that images of the past are constantly produced and reproduced in the archive (Ketelaar 2012), we understand that through working in the archive, we have taken active part in the process. Performing the research, the authors have thus had a double scholarly focus, by both scrutinising the historicity of the archive in itself and critically reflecting on the practical procedure of conducting research in that archive. In other words, the contributors not only critically review the historical period they are studying, but also discuss their own research practice and methodological procedures, and how they affect the result. In this way, we hope to display the multileveled temporality of any historical process, and perhaps most importantly, of any historical narrative and historicity.

\section{Gunnar Lundh in Focus}

The man in the photo in the opening example, Gunnar Lundh, is a central figure in the context of this issue, since it is the offspring of the research project Images and Stories of Everyday Life (Vardagens bilder och berättelser), which revolves around his photographic collection, that is found in the archive of the Nordic Museum in Stockholm. ${ }^{1}$ Gunnar Lundh was a professional photographer, active during the first half of the twentieth century. When he died in 1960, he left a collection of approximately 300000 photographs that was eventually donated to the Nordic Museum.

Gunnar Lundh worked mainly as a reportage and press photographer. Three factors made him especially interesting. Firstly, he was very early in using a small-screen camera; he got a Leica in 1927 while other professional photographers still worked with large or medium format bellows cameras. The small camera made it possible for him to take many shots and to move around quite freely (even though he often carried both the little Leica and bigger cameras on missions, and you find the same motive both in medium and small format in the archive). Secondly, Lundh was early in starting a photo agency of his own, in which he gathered almost all the photos he took. At the photo agency, which he kept in 
his house, there was a huge selection of paper copies organised under different headings that customers could choose from. Lundh also kept a systematised archive of the contact sheets, as well as of the negative rolls. He kept the agency until his death in 1960. Thirdly, Lundh was interested in the everyday aspect of life and society and always carried his camera with him. You find motifs from all kinds of social milieus and situations in his production, and as he saved most of his photographs-no matter the technical or artistic quality-the collection is a broad and deep documentation of everyday life in Sweden, as well as other countries, during the period.

The research project also looks at the answers from the Nordic Museum's questionnaires during the period Lund was active. The museum has been engaged in sending questionnaires to a number of designated informants since the 1920s, as a way of collecting everyday life experiences. The questionnaires have been referred to as a kind of "interview by mail" (Österman 1991:9) and the archive today contains more than 460 different questionnaires (Nordiska Museet 2018).

Gunnar Lundh was working as a photographer from the 1920s to the late 1950s. This was a socially and politically vibrant period in Sweden, which is generally regarded as the dynamic and formative years during which the Swedish welfare state emerged. The Social Democratic Party was in office from 1932 to 1976, except for a few years during Second World War, giving the Government an opportunity to form a strong and progressive welfare policy aimed at health care issues and social security. Sweden was spared military battles and bombings during Second World War, and had a good economic starting point after the war. The public sector grew strong and the Swedish Cooperative Union (KF) was a solid player in society.

Functionalism and social engineering became cornerstones in a growing welfare state. In what has come to be known as "The People's Home Speech" (Folkhemstalet) in 1928, Prime Minister Per Albin Hansson launched the concept "the people's home" as a metaphor for a society where everyone was equal and worked together as a family. In this rhetoric, striving for a welfare state was a leap from an old society characterised by poverty, filth, darkness, inequality and tradition, into the new society characterised by welfare, hygiene, light, equality and modernity. In parallel, industrialisation reached Sweden quite late and the contrast between the modern cities and undeveloped rural areas was striking. This contrast is reflected in the work of Gunnar Lundh, and the photographic archive includes motifs from old-fashioned farming, where horses draw the ploughs, to newly built high-rise buildings in suburbs, and modern facilities such as public swimming pools. 
Not everyone was included in the egalitarianism of the "people's home", and depending on context, race, class, gender and physical or psychological ability people could be excluded by the welfare state (Broberg \& Tydén 1991, Svensson 1993, Catomeris 2004). Another critique of the period concerns what is perceived as the socio-cultural effect of the central government's efforts to rationalise every trace of misery out of people's lives with rational scientific methods. It has, for example, been argued that the robust and supervisory politics of the "people's home" resulted in a society characterised by both widespread social trust and deep-rooted individualism. The relationship between the individual and the state was privileged at the expense of kinship and other group relationships; a system, which, on the one hand, contributed to material security at an individual level, but on the other hand, could serve as a breeding ground for social alienation (Hirdman 2000, Berggren \& Trädgårdh 2006).

The Swedish welfare state and the "people's home" are concepts that bear a strong symbolic meaning in the historiography of twentieth-century Sweden. Today, groups of different political orientation, from left to right, are claiming the legacy of the social and political structure of that era (Norocel 2013). This ongoing struggle for priority of interpretation highlights the palpable political aspects of the understandings and uses of the archival material from the period. In several of the contributions in this issue, for example Hörnfeldt, Larsson, Hylten Cavallius \& Fernstål, Bäckman, the relationship between the archives and the political and cultural developments in society is highlighted.

\title{
Ways to Remember Collectively: Heritage, Museums, Photographs
}

\begin{abstract}
Photography, archive and memory are intimately connected. Memory and photography both involve the process of recording images that may be used to recall the past. Memory itself is often characterized as an archive: a store house of things, meanings and images (Cross and Peck 2010:127).
\end{abstract}

Photographs have, for a long time, constituted an important source for cultural historic research and are consequently considered a vital category in a museum's collections and archives. Large parts of Gunnar Lundh's photographic archive have been donated to the archive of the Nordic Museum (see Steinrud in this issue for further details about the donation). Today, many of the photos are available on the Internet. Gunnar Lundh's photographs can be considered as part of a Swedish visual heritage. 
With the last decade's introduction of a vivid and critical heritage discourse in mind (see for example Hewison 1987, Anselm 1993, Harrison 1994, Brett 1996, Kirshenblatt-Gimblett 1998, Lowenthal 1998, Hall 1999, Aronsson 2000, Blake 2000, Graham, Ashworth \& Tunbridge 2000, Harvey 2001, Eriksen, Garnert \& Selberg 2002, Holtorf 2005, Smith 2006, Harrison 2008, Winter 2013) it may be worthwhile to place a marker on what definition is employed here. The analyses are inspired by a perspective where heritage is seen as a process (Harvey 2001, Harrison 2012) in which objects and ideas of the past become resources for, and in, the present (Smith 2006, Graham \& Howard 2008). Heritage will consequently be interpreted as an arena for societal and political negotiations. A key concept is heritagisation, which refers to the processes whereby certain objects, landscapes, traditions, et cetera, are framed as particularly dense symbols of shared characteristics or values.

An important concept in comprehending heritage is the notion of collective memory. The theory of collective memory was developed by the French philosopher and sociologist Maurice Halbwachs, in academic dialogue with historians like Lebvre and Bloch (Olick, Vivitzky-Seroussi \& Levy 2011) during the first decades of the twentieth century. However, it was in the middle of the century, when his essays were posthumously published on various occasions, that the concept started to become a prominent feature in the academic discussion (Halbwach 1992). Since then, the collective aspects of remembrance and forgetting have been both contested and developed (Connerton 1989, Assman 1995, Ricœur 2004). Borrowing Goffman's notion of (social) frames, Irwin-Zarecka has showed how public "frames of remembrance" influence individual understandings of past events (1994). Astrid Erll also departs from the Halbwachian premise that memories arise from social frames that are both functional for, and reproductions of, the distribution of power. However, Erll also shows how, in a globalised world, those social frames are in constant flux, causing collective memory to change over time and space.

Without doubt, the idea of a "collective memory" has spread widely and the concept is often referred to, both within and outside of academic contexts. However, the concept has also been criticised for being too vague and too sweeping. Among other things, Wulf Kansteiner (2002) argues that the metaphor is often taken too literally, and that "collective memory" is analysed as a kind of "individual memory", albeit on a larger scale. This threatens to lead the investigation in the wrong direction, and away from the communicative ways in which collective remembrance work.

Memory, whether it is individual or collective, is a complex concept. On an overall level, memory has to do with how the past is perceived. It can be understood as an ability (a person or a computer can have a good memory if able to store a lot 
of information over time) or as a noun (I have this great memory from my latest vacation). However, from a constructivist perspective, memory is conceptualised as a verb, something that takes place. One way to put it is that memory is the past as it is carried, preserved and transferred over time by man. Keeping in mind the collective character of memory, the carrying, preservation and transference take place in social processes.

The camera is often seen as an objective witness, simply capturing what happened in front of the lens at the moment the photographer pressed the shutter button. However, a photograph is a cultural product as much as any other artefact. The photographer constructs the photo, even if unconsciously. Still, as memory mediums, photographs are persuasive, as they not only show a recognisable situation, but also give the viewer an experience: a photograph makes you feel and relate to what you see in a special way. Consequently, the photographic medium has played a crucial role in the construction of collective memory (Edwards \& Hart 2004:6ff). Photos, with their putative ability to freeze moments and carry them over time, in conjunction with their affective qualities, are often treated as a kind of high-density memory entity within memory institutions. Erll illustrates how the photographic medium's role in collective memory processes increases in a globalised world, when iconic and widely shared images from historic events "links each individual representation of the past with the history of mediated cultural memory" (2011: 142f). The contributions in this issue show that photographs are a complex source material. Photographs can both affect images of the past in certain ways, as in the examples given by Bäckman, but they can also contribute to a deeper understanding and a broader knowledge of the past, like the examples contributed by Steinrud and Gustavsson demonstrate.

Cultural heritage is a word that relates to collective memory at an overall level, and museums and archives are prominent institutions at its service. Based on this perspective, photographs and photographic archives are prominent elements in the construction of a collective memory:

Charged with documenting and preserving that which is considered valuable, the museum has also become the institutionalized arbiter of value, determining what is worth collecting and saving for the future. Because photographing and archiving are primary ways of assigning value, they often occupy a central position in the museum's task of constructing and perpetuating a shared conception of a collective past (Becker 1992:3). 
In an article from 1992, media scholar Karin Becker explored the role of the Nordic Museum's photographic archive in the construction of a common Swedish cultural heritage. She demonstrated how criteria for assessing the credibility of photographs in the archive had fluctuated over time, and concluded that the archive had "entered the ideological domain with the power to show us the way things were" (Becker 1992:17).

In most respects, Becker's analysis is still accurate. The photographic archive at the Nordic Museum is still to be regarded as an authority and main actor in the formation of a public idea of what history we share and with a structure that "maintain[s] a hidden connection between knowledge and power" (Sekula 2003:447). However, technical developments since 1992 have added a new dimension to the photographic archive's process of constructing a collective past, namely digitalisation. Today, the Nordic Museum's archive, along with practically every other museum and archive, does not merely "determin[e] what is worth collecting and saving for the future", but also selects what is worth publishing on the Internet. The archive is thus no longer only part of the museum's back stage, but is constantly on potential display and accessible to anyone who is online.

Archives and museums are "memory institutions", or in Jan Assmann's words "mnemonic institutions" (1995), that is to say bodies where collective memories take place. It is commonly recognised that heritage, as a form of collective memory, should include as many citizens as possible. In democratic nations, authorities and other controlling stakeholders have therefore striven for a democratic heritage. In the last decades, the main aspiration in this democratic endeavour has been digitisation and digitalisation (Dahlgren 2009:81). Confidence in digitalisation's ability to create a more inclusive heritage has been overwhelming, and without doubt, there have been many successful digitisation and digitalisation projects (Henning 2006, Waterton 2010, Wasserman 2011, Strandroth 2012).

However, there is reason to maintain a critical stance towards the trust in digitalisation as a one-way street to an egalitarian and inclusive heritage. As Tayler and Gibbon, researchers in areas of digital heritage, put it, digitalisation projects "are not inherently democratic", but may on the contrary "reinforce non-democratic structures" (2017:406). Digitalisation is certainly an effective tool when it comes to reaching a larger number of users and is used as a kind of heritage amplifier. However, as much as this amplifier may enforce positive aspects of heritage, it may also strengthen imbalances in representation and re-produce historically embedded disproportions in the museums' record and collection (Macdonald 2006:3).

In the broad notion described by Foucault, archives constitute a system with bearing on what is comprehensible in a general sense; the archive stands out as the very "system of discursivity" (Foucault 2002, see also Manoff 2004). In addition, 
an archive is an apparatus for organising power and structuring power relations. In the archive, the past, present, and future are related to each other, as the potentials of the past and the present are linked to the future (Derrida 1996). It is thus by managing the traces of what has been that the archive becomes an authority: the power stems from a capability to shape the conditions of individual and collective memories. However, as the contributions by, for example, Ekström and Nylund Skog in this issue show, archives never develop in a cultural vacuum, but are both shaped by, and reproduce specific ideologies and scientific paradigms.

A pedagogic way to place the contributions in this issue in relation to the archive as an apparatus of power is to use the French historian Pierre Nora's theoretical distinction between the concepts of history and memory as a point of departure. In Nora's terminology history demarks a society's established narrative about its past and describes past times from a bird's-eye perspective. History is about relations between entities such as kings, armies, authorities or nations, in other words abstract units. Memory, in contrast, is images of the past as applied by people as they live their everyday lives. Unlike history's solid version of earlier periods, people's notion of the past as memory is moulded in a dialectic movement between what is remembered and what is forgotten, and as memory lives in the minds of and communication between people, the picture of the past changes over time. While memory is concrete and lived, history is symbolically encapsulated in so called lieux de memoire, sites of memory, a concept that signifies any corpus that expresses the nation's shared past.

Nora's critical stance is that the dynamic and creative potentials of people's understanding of their past as memory threatens to be circumscribed by an authoritarian effort to create a unifying narrative of the nation's history (1989). Nora can of course be criticised for making a rather coarse division between official history and individual memories, and for building his theory on a romanticised comprehension of a pre-modern way of life, as well as utilising a western perspective. A range of scholars have offered both harsh critiques and developed his thinking in different ways (Assmann 1995, Ho Tai 2001, Kansteiner 2002, Assmann 2006, Erll 2011).

Even if Nora might seem a bit outdated, his discussion on the mutual relationship between people's memory making and society's history writing is still valid and illuminating. The articles in this issue direct their search light toward typical memory sites in Nora's sense, such as museums and archives. The original task of these institutions was to gather artefacts and stories of the past, and to unify them in a greater narrative, to form collective memory. However, our aim has not been to capture the grand narrative in the archive, but the opposite: to search for fragments and pieces of individual stories, what could be called petite 
narratives. In other words, we have been looking for the memories in the archive of which history is assembled. In the contributions by, for example Gustavsson and Steinrud, it becomes evident that even seemingly static and well-organized memory institutions, such as archives, are formed by people's work, which entails the mistakes, chance and occasional lack of attention of everyday life.

If archives can be considered sites of power that organise individual and collective memories, photographs have been described as cornerstones in this process (Cross and Peck 2010). To a large extent, we are looking for the petite narratives by investigating the photographs in Gunnar Lundh's photo collection. Photographs have been regarded as a popularised memory process that can offer an alternative to the official history, even if motives often become absorbed by the dominant narrative (Samuel 2012). Bearing this in mind, we have approached the photographs with the intention of keeping their potential intact in order to add ambiguities to official history.

\section{The Contributions}

The lion's share of the contributions to this special issue emanates from the project Images and Stories of Everyday Life. When the same material base has been examined from different perspectives, the nuances between different approaches become clear. As researchers with diverse interests and prerequisites are processing one collection, there is a resonance between the articles. However, three articles provide relief by dealing with similar issues, but based on material other than the Nordic museum's archive material. The contributions discuss the problems of how to interpret archived sources from different points of view, scrutinising a variety of materials. However, even if questions, materials and perspectives change, the need for well-founded contexts, developed contextualisation and elaborate reflections return in all articles.

In her article, Marie Steinrud grapples with the biography of Gunnar Lundh. Steinrud shows how data from different sources and archives can be combined to deepen the knowledge of a collection or a single record. Applying this biographical method, Steinrud demonstrates how a broadening of the personal and professional context of a photographer can help a researcher to extract more dimensions from photographic images as a source of knowledge about the past.

Also using the photographs of Gunnar Lundh as a point of departure, Maria Bäckman directs the searchlight towards how a specific motif, the "contract labourers" (statare), which has travelled in and out of different media contexts during the last century. The pictures of the "contract labourers" were used for designated political purposes during the modernisation of society, a circumstance that affected how the category was later interpreted. Another theme of the article is 
the intertextual relation between the driving actors in the process, Lundh and the author Ivar Lo Johansson, and the collective memory process of the conception of "contract labourers" in Sweden. Through a close reading of Lundh's photos of statare, Bäckman argues that contemporary museum settings illustrating the life of the group (for example the Farm Labourer's Cottage at the Skansen open-air museum in Stockholm), to a large extent, are inspired by Lundh's compositions.

Helena Hörnfeldt offers another entrance to the Lundh collection. She examines what happens if the research is guided by a search for an unmarked category, in this case children and childhood, in such an immense and diverse photographic material. Being a researcher with documented knowledge about children and childhood in Sweden during the twentieth century, Hörnfeldt reveals how Lundh as a professional photographer both contributed to, and was influenced by, the new idea of the child, as it was formed during the period in question. The methodological stance is used to illustrate how an initial understanding of a field can lead the researcher to become analytical, productive and generate new insights.

By combining several different categories of source materials, Marianne Larsson illuminates how significant changes in society are not only important for the answers to the museum's questions, but also have a bearing on the questions that have been asked. Larsson's example is the thorough reform of the statutory annual leave that took place in 1938. Her method is to use three different sources - public reports, photographs and questionnaires-showing how the sum produces a more dense description than the separate fragments.

Simon Ekström discusses how a part of an archive, in this case the Nordic Museum's collections of excerpts, can be read as a materialisation of a certain scientific approach. Ekström follows how the information collected by early folk life collectors about beliefs in folklore creatures has found new ways out of the archive to inspire new popular expressions. The transforming pendulum movement continues as these new expressions become the subject for contemporary collecting actions by the museum. The argument is that the knowledge of yesterday may be considered obsolete from a present-day academic perspective, but that the excerpts in the folk life archive have kept attracting interest, thus producing (old) knowledge that has transformed into modern vernacular folklore expressions.

The archive's, and not least the archivist's, role in establishing social categories are the central points of analysis for Charlotte Hyltén-Cavallius and Lotta Fernstål. The authors scrutinise the archive as a power instrument, illustrating how the twentieth-century archivists perceived the folk life archive as a community-building institution, and collaborated with other authorities, such as the police, in the mapping of specific groups in society. The article does not address the Lundh collection, but focuses on archival collections relating 
to "tattare" and "zigenare", and shows how these categories became part of the archives as documentation of the majority society's prejudices.

Karin Gustavsson tries, based on her own work with a collection from the 1940s, to verbalise the silent knowledge that experienced archive researchers use to orient themselves through archival material. Departing from Barthes' concept of punctum Gustavsson describes a both physical and mental ability to perceive minor disturbances or deviations in the scheme, which leads to new constructive traces.

The folk life collector Karl Gösta Gilstring's collection, today found in the archive of the Department of Dialectology and Folklore Research in Uppsala, is the subject of the article by Susanne Nylund Skog. Nylund Skog develops a discussion about the connection between a place and a person in an archive. By applying a narrative analysis to the correspondence between Gilstring and one of his informants, Carl Nelson, who lived in Manistique, Michigan, USA, but provided Glistring with stories of his birthplace in Småland, Sweden, Nylund Skog shows how places are socially and culturally constructed in the archive.

Instead of solely studying what the photos in Gunnar Lundh's archive describe, Mattias Frihammar's approach is to search for both articulations and silences in the photographic archive. As a method, Frihammar is trying out the concept of visual silence in the analysis of photographs from three different occasions. The analytical premise is that silences are socially constructed and culturally productive, and that attention to what is not said can give new entry points to an archived material.

As I finish writing this introduction, it is still October 2019. I do not know what date, year or season it will be when you finish reading it, just that it will be in the future for me, right now to you, and for later readers, in the past. However, no matter when, you will still be able to look Gunnar Lundh deep in the eyes in the photo on first page where he is standing among the lupines.

The past is always in dialogue with the present and the future, and this dialogue often takes place through material mediums. The archive is such a medium, and it is our hope that the articles in this issue will assist you by contributing analytical tools and methodological measures in the process of extracting knowledge from it. 


\section{Culture Unbound}

Journal of Current Cultural Research

Mattias Frihammar is an ethnologist at the Department of Ethnology, History of Religion and Gender Studies (ERG) at Stockholm University. He is initiator of the Critical Heritage Studies Network at Stockholm University and coordinator of the Bachelors Program in Museum and Heritage Studies at Stockholm University. He is currently involved in the research project Making a Military Heritage: Gender and Nation in Sweden's Cold War History. This article is part of the project Images and Stories of Everyday Life (Vardagens bilder och berättelser), financed by The Royal Swedish Academy of Letters, History and Antiquities, and The Swedish Foundation for Humanities and Social Sciences. Email: mattias.frihammar@ etnologi.su.se

\section{Notes}

1 The project was funded by the Royal Swedish Academy of Letters, History and Antiquities and Riksbankens Jubileumsfond, and involved a collaboration between Nordic Museum in Stockholm and the Department of Ethnology at Stockholm University.

\section{References}

Anshelm, Jonas (ed.) (1993): Modernisering och kulturarv: essäer och uppsatser. Stockholm: Symposion.

Aronsson, Peter (ed.) (2000): Makten över minnet: historiekultur i förändring. Lund: Studentlitteratur.

Aleida Assmann, (2006): "History, Memory and the Genre of Testimony", Poetics Today, 27:2, 261-273.

Assmann, Jan (1995): Collective Memory and Cultural Identity. Trans. John Czaplicka. New German Critique 65, 125-133.

Becker, Karin (1992): "Picturing our past. An Archive Constructs a National Culture", The Journal of American Folklore, 105:415, 3-18.

Berggren, Henrik \& Trägårdh, Lars (2006): Är svensken människa?: gemenskap och oberoende i det moderna Sverige. Stockholm: Norstedt.

Blake, Janet (2000): "On Defining the Cultural Heritage". The International and Comparative Law Quarterly, 49, 61-85.

Brett, David (1996): The Construction of Heritage, Cork: Cork University Press.

Bringéus, Nils-Arvid (ed.) (1988): Folklivsarkivet i Lund 1913-1988: en festskrift till 75-årsjubileet. Lund: Folklivsarkivet.

Broberg, Gunnar \& Tydén, Mattias (2005): Ö̈nskade i folkhemmet: rashygien och sterilisering $i$ Sverige. Stockholm: Dialogos.

Catomeris, Christian (2004): Det ohyggliga arvet: Sverige och främlingen genom tiderna. Stockholm: Ordfront.

Connerton, Paul (1989): How societies remember. Cambridge: Cambridge Univ. Press.

Cross, Karen and Peck, Julia (2010): "Editorial: Special Issue on Photography, Archive and Memory". Photographies, 3:2, 127-138.

Dahlgren, Anna (2009): "Tankar och tillgänglighet och fotografier i arkiv", Anna Dahlgren \& Pelle Snickars (eds): I bildarkivet. Om fotografier och digitaliseringens effekter, Stockholm: Kungliga bibliotekets skriftserie, 59-89. 


\section{Culture Unbound}

Journal of Current Cultural Research

Derrida, Jacques (1996): Archive fever: a Freudian impression. Chicago: University of Chicago Press.

Edwards, Elizabeth \& Hart, Janice (eds) (2004): Photographs Objects Histories. London: Routledge.

Eriksen, Anne, Garnert, Jan \& Selberg, Torunn (eds) (2002): Historien in på livet: diskussioner om kulturarv och minnespolitik. Lund: Nordic Academic Press.

Erll, Astrid. (2011): Memory in culture. Houndmills, Basingstoke, Hampshire: Palgrave Macmillan.

Foucault, Michel (2002): Archaeology of knowledge. 2nd ed. Hoboken: Taylor and Francis.

Graham, Brian, Ashworth, Gred \& Tunbridge, John (2000): A Geography of Heritage: Power, Culture and Economy, London: Arnold Press.

Graham, Brian \& Howard, Peter (2008): "Introduction: Heritage and Identity," Brian Graham \& Peter Howard (eds): The Ashgate Research Companion to Heritage and Identity, Aldershot: Ashgate.

Gustavsson, Karin (2014): Expeditioner $i$ det förflutna: etnologiska fältarbeten och försvinnande allmogekultur under 1900-talets början. Diss. Lund: Lunds universitet, 2014.

Halbwachs, Maurice (1992): On collective memory. Chicago: University of Chicago Press.

Hall, Stuart (1999): "Whose Heritage? Unsettling "The Heritage", Re-Imagining the Post-Nation", Third Text, 46, 3-13.

Harrison, Richard (ed.) (1994): Manual of Heritage Management, London: Butterworth Heinemann.

Harrison, Rodney (2008): "The Politics of the Past: Conflict in the Use of Heritage in the Modern World". Graham Fairclough, Rodney Harrison, John H. Jameson \& John Schofield (eds) The Heritage Reader London: Routledge, 177-90.

Harrison, Rodney (2012): Heritage: critical approaches. Hoboken: Taylor and Francis.

Harvey, David. (2001): "Heritage Pasts and Heritage Presents: Temporality, Meaning and the Scope of Heritage Studies". International Journal of Heritage Studies, 7:4, 219-338.

Henning, Michelle (2006): “New Media”, Sharon Macdonald (ed.): A Companion to Museum Studies, Malden, MA: Blackwell, 302-318

Hewison, Robert (1987): The Heritage Industry, London: Methuen.

Hirdman, Yvonne (1989): Att lägga livet tillrätta: studier $i$ svensk folkhemspolitik. Stockholm: Carlsson.

Holtorf, Cornelius (2005): From Stonehenge to Las Vegas: Archaeology as Popular Culture, Walnut Creek: AltaMira.

Ho Tai, Hue-Tam (2001): "Remembered Realms: Pierre Nora and French National Memory", The American Historical Review, 106:3, 906-922.

Johansson, Jesper \& Thor Tureby, Malin (2017): "The making of cultural heritage and ethnicity in the archive", Christina Johansson \& Pieter Bevelander (eds): Museums in a time of migration: rethinking museums 'roles, representations, collections, and collaborations. Lund: Nordic Academic Press,169-196.

Irwin-Zarecka, Iwona (1994): Frames of remembrance: the dynamics of collective memory. New Brunswick [N.J.]: Transaction Publishers.

Lowenthal, David (1998): The Heritage Crusade and the Spoils of History (Cambridge: Cambridge University Press.

Kansteiner, Wulf (2002): "Finding Meaning in Memory: a Methodological Critique of Contemporary Memory Studies", History and Theory, 41, 179-197.

Ketelaar, Eric (2012): "Cultivating archives: Meanings and Identities". Archival Science, 12:1, 19-33. 


\section{Culture Unbound}

Journal of Current Cultural Research

Klein, Barbro (2003), "Nm 223 Personlig hygien: Reflektioner kring frågelistor, meddelaransvar och vetenskap", Bo Nilsson, Dan Waldetoft \& Christina Westergren (eds), Frågelist och berättarglädje: Om frågelistor som forskningsmetod och folklig genre, Stockholm, Nordiska museet, 69-85.

Kirshenblatt-Gimblett, Barbara (1998): Destination culture: tourism, museums, and heritage. Berkeley: Univ. of California Press.

Koselleck, Reinhart (2004). Erfarenhet, tid och historia: om historiska tiders semantik. Göteborg: Daidalos

Wulf Kansteiner (2002): "Finding Meaning in Memory: a Methodological Critique of Contemporary Memory Studies", History and Theory, 41, 179-197.

Macdonald, Sharon (2006): "Expanding Museum Studies: An Introduction". In $A$ Companion to Museum Studies Macdonald (ed.): Malden, MA: Blackwell, 1-12.

Manoff, Marlene. (2004): Theories of the Archive from Across the Disciplines. Portal: Libraries and the Academy. 4. 10.1353/pla.2004.0015.

Nagel, Erik (2012): I dialog med muntliga och skriftliga berättartraditioner: en undersökning av svenska sjömäns levnadsberättelser. Diss. Stockholm: Stockholms universitet, 2012.

Nilsson, Bo G. (1996): Folkhemmets arbetarminnen: en undersökning av de historiska och diskursiva villkoren för svenska arbetares levnadsskildringar. Diss. Stockholm : Univ.

Nordiska Museet (2018): avaible at https://www.nordiskamuseet.se/samlingar/ insamling/fragelistor (accessed December 12, 2018)

Nora, Pierre 1989: "Between Memory and History: Les Lieux de Mémoire. Representations", No. 26, Special Issue: Memory and Counter-Memory, spring: 7-24.

Norocel, Ov Cristian (2013): “'Give us back Sweden!': a feminist reading of the (re)interpretations of the 'folkhem' conceptual metaphor in Swedish radical right populist discourse", Nora 2013 21:1, 4-20.

Nystrand von Unge, Elin (2019): Samla samtid. Insamlingspraktiker och temporalitet på kulturhistoriska museer $i$ Sverige, Stockholm: Vulkan.

Olick, Jeffrey K., Vinitzky-Seroussi, Vered \& Levy, Daniel (eds) (2011): The collective memory reader. New York: Oxford University Press.

Österman, Annika (1991). Människors egen historia: Om Nordiska museets frågelistverksamhet. Stockholm: Nordiska museet.

Ricœur, Paul (2004): Memory, History, Forgetting. University of Chicago Press.

Sandberg, Marie \& Jepersen, P. Astrid (2017): "Inledning”, Christensen, Søren (ed.) Kultur som praksis: etnologiske perspektiver på individualitet og fallesskab, kultur og historie. København: Hans Reitzel, 7-11.

Samuel, Raphael (2012): Theatre of Memory, Vol. 1, Past and Present in Contemporary Culture. London: Verso.

Sekula, Allan (2003): "Reading an archive. Photography between labour and capital", in Wells, Liz (esd.) The photography reader. London: Routledge.

Silvén, Eva (2004): "Samtiden eller för framtiden: Om ett kunskapsbygge i senmoderniteten, Lena Hammarlund \& Eva Silvén (eds), Samhällsideal och framtidsbilder: Perspektiv på Nordiska museets dokumentation och forskning, Stockholm: Carlssons, 140-228.

Smith, Laurajane (2006): Uses of Heritage. London: Routledge.

Snellman, Hanna (2010): "Performing ethnography and ethnicity: An early documentation of Finnish immigrants in Nordiska Museet", Ethnologia Europea: Journal of European Ethnology, 40:2, 47-59.

Winter, Tim (2013): "Clarifying the Critical in Critical Heritage", International Journal of Heritage Studies, vol. 19:6, 532-545. 


\title{
Follow Lundh! Between Text and Context in a Photographer's Archive
}

\author{
By \\ Marie Steinrud
}

\begin{abstract}
No matter how well documented a life is, only shards, bits and pieces remain of what was once a vibrant person, with purpose, memories, feelings, actions and ideas. For any historian, these slivers are what remains and what can be used to access a past. This article presents a case study where the photographs taken by the photographer Gunnar Lundh (1898-1960) are in focus. The archive contains next to no written sources, and the information about the motifs is scarce. This is in fact the fate of many personal archives, especially those containing few written sources. The contact sheets Gunnar Lundh used in his business as a photographer provide some mostly routine and brief information, usually the year and sometimes where the photo is taken, in "Denmark" or "Skåne". A majority of them are picturing anonymous individuals. The lack of information makes the archive of Lundh, in a sense, silent or mute. The purpose with my research is to investigate what happens to a photograph or a set of photographs when more contexts are added. By adding biographical knowledge it is possible to read the photographs. In this, I am using the art historian Joan M. Schwartz's ideas about functional context. The process of adding context to an archive is a negotiation of the past that will contribute new dimensions in our collective memory, and also generate new, additional archives. There are options other than silence, and the inevitable reversion and degradation into oblivion for those silent, or mute, personal archives in focus here. A biographical method can however operate in the area between text and context, joining them together and thus letting the material speak.
\end{abstract}

Keywords: Functional context, Archival silence, Biography, Method, Photography.

Steinrud, Marie: "Follow Lundh! Between Text and Context in a Photographer's Archive", Culture Unbound, Volume 12, issue 1, 2020: 16-35. Published by Linköping University Electronic Press: $\underline{\text { http://www.cultureunbound.ep.liu.se }}$ 


\section{Introduction}

The starting point of this article is the never neutral photograph. Every photograph is a result of a multitude of historical, aesthetic and cultural frames of references, as well as relationships, meanings and interests connected to the photographer (Batchen 1999: 9, Sandweiss 2007: 193). My goal is to contribute to the discussion about what happens to a photograph (or a set of photographs) when individual context is added (Kozloff 1992: 57-60). By using a biographical method and following the individual throughout her or his life, building knowledge of the individual fate, the different types of materials in the archive can be put into context, thus being able to break the silence (Mason and Zanish-Belcher 2007, Farge 2013).

The article investigates the archive in search of the motifs of the photographer Gunnar Lundh (1898-1960). After his death his wife Ester Lundh donated documents from their business to Nordiska museet in Stockholm. The archive consists mainly of photographs in various forms and a smaller amount of documents describing the everyday business of a photographer. The extensive category in the archive is copies of the photographs of Gunnar Lundh, arranged after his own categories. ${ }^{1}$ Besides this, the contact prints constitute a large part of his personal archive. The collection amounts to about 10000 , where contact prints are glued to the sheets and provided with a number connecting them to a negative. The smallest category constitutes documents from his business, such as some correspondence with business contact in Europe and Sweden. This means that even if the archival integrity of the archive has been respected, it is difficult to gain an overview of the complete personal archive. In total, the amount of photos is about 300 000. In addition, some letters from Ester Lundh to the museum in the 1960s are preserved in the archive. Not much else is today known about why the archive was added to the collections in the museum and how, or even how it has been used.

This is in fact the fate of many personal archives, especially those containing few written sources. The lack of information makes the archive of Lundh, in a sense, silent or mute (Hobbs 2001). My undertaking as a cultural historian is to examine different ways to use the photographs taken by Lundh as research material. In doing so, the context is important in order to-in a sense-understand the material, its background and its origins.

The present study consists of two parts, where the first aim to give some general information of the life and work of Gunnar Lundh and describe biography as a research method. The second part will show how this method can be applied to his personal archive at Nordiska museet and how archival slivers joined together can offer a previously silent material a voice. 


\section{Life and work ${ }^{2}$}

Gunnar Lundh was the fourth child of Sofia Elin Marie Andersson (1873-1939) and her husband, the well-known photographer Peter Lundh (1865-1943) in the parish of Väsby, just outside the small town of Höganäs in the south west of Sweden. The couple had five children; Arthur Benvard died seven days old in 1893 and was followed by Astor Benvard (1894-1970) and Anny Berta Linnea Evelina (1896-1944). Gunnar Herbert was born in 1898 and the siblings had a younger brother, Carl Erik, born 1909, who in 1921 died of a skull fracture acquired while playing in the harbour.

Peter Lundh, or Peter P Lundh as he called himself, had opened one studio in 1886 in Skättekärr and another in 1892 in Höganäs. Later, in 1894, he opened a branch in Mölle and another in Arild in 1907. During this time, these were well-known and popular tourist destinations, attracting many visitors every year. Peter P Lundh is perhaps best known for his photographs of bathing and swimming people, and, most of all, the mixed sex bath in Ransvik (Olsheden and Olson 1967, Ranby 2013). Gunnar Lundh took part in the family business from an early age and learned the trade and art of photography both in his father's studio and abroad in Denmark and Germany, countries he during his life repeatedly returned to. During the 1920s he worked as a portrait photographer in Berlin, at a department store chain in pre-World War II Germany called Wertheims. The chain's largest and most famous store-and during the 1920s Europe's largestwas situated in Leipziger Platz in Berlin, and here Gunnar Lundh worked, taking portrait pictures (Rehnig 1999: 23-27). However, his camera lens was more directed towards picturing the everyday life in the streets of Berlin, photographs that are well represented in the material at Nordiska museet. It was during this time that he first became acquainted with the new photography technique: a small and handy camera that would become his hallmark, the Leica (Kross 1955: 118). He later returned to Sweden and settled in Stockholm, opening up his photography business and founding his photo agency, working as a free-lance reportage photographer. He sold his pictures to many different kinds of magazines, such as Folket i Bild, Signalen, Metallarbetaren and Lantarbetaren (see Bäckman in this volume). He also produced four illustrated books, the most famous of them being Statarna i bild published in 1948, which was a result of a more than ten-year long partnership with the author Ivar Lo-Johansson, who also wrote the text in the book. Two years later Malmö was published, followed by Julotta and Midsommar.

The years around the late 1930s and early 1940s were turbulent in the Lundh family. In May 1939 his mother died and left his sister Berta and his father to attend to the family business. However, this was not uncomplicated. Berta had since early adulthood shown signs of depression and mental illness, something her mother had coped with, nursing her daughter in their home. The death of their 
mother triggered a psychosis, and Berta had to spend some time at the hospital in Helsingborg. Another setback for the family was the death of Peter P Lundh in 1943. Only a couple of months later, Berta Lundh commited suicide, leaving the family devastated. Now Astor and Gunnar Lundh shouldered the burden of attending to the family business in the south of Sweden, as well as Gunnar Lundh's own business in Stockholm.

During the early 1940s, Gunnar Lundh had met Ester Götilda Boman (née Carlsson, 1894-1969), a childless widow. The couple married in 1943 and Ester moved into Gunnar Lundh's apartment on Döbelnsgatan 35. From the apartment, his photographic business operated, leaving very little space for everyday life. Ester Lundh became, over time, involved in her husband's business, and even though she held a position as a clerical worker at an office in Stockholm, she spent time managing different tasks in the family business.

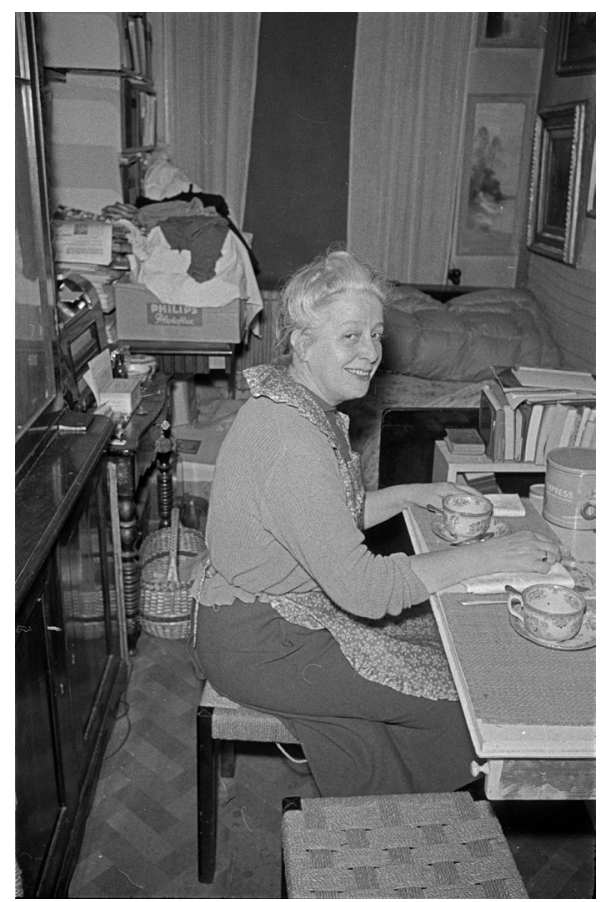

Fig 1. Picture of their home.

How and exactly when Gunnar Lundh met his future wife is not known. She had moved to Stockholm after her first husband's death, and just like Gunnar Lundh she grew up in the south of Sweden. There are many different stories about Ester Lundh; everyone is more or less to her disadvantage. She was accused of 
being controlling and acquisitive, and her ordeals with Nordiska museet after the donation of her husband's photographs were many and confused. ${ }^{3}$

During the late 1950s, Gunnar Lundh's interest in photography decreased noticeably. Instead, he spent more time selling postcards and antiquities. At this time, his photographic collections, an image bank, had become famous and the amount of pictures it held was remarkable: some 290000 black and white, and about 11000 colour, photos. It was the first modern photographic image bank, where the customers themselves could choose from thousands of photographs (Nilsson 1984: 308, Mölleryd 1958).

\section{Biography as Method}

Archives have always been about power and power relations: the power of those establishing or imposing the archive, the power of those handling the archive records, the power of setting up an archive inventory and making decisions about what and what not to save and, of course, the power of the researchers and public who study the archival material, interpreting and analysing it (Berger 2013). This is hardly anything new; a common notion in archival discourse is that what ends up in the archive mirrors the powerful of society. The power-less constitutes a large group whose voices are silent or unheard in the remains of the past. This silence of course also implies a voice, silenced or denied the opportunity to speak (Carter 2006, Derrida 1995: 7). But the records themselves also possess power. They hold information about events, people, transactions, and agreements. Their format can force information to be presented in a special way and exclude other types of data (Schwartz and Cook 2002). There are limits to what an archive can provide regarding information about the material stored therein. Some information will be unconditionally lost, misinterpreted or misunderstood (Thomas, Fowler \& Johnson 2017). To approach such a rich photographic material as the one Gunnar Lundh left behind proved to be somewhat of a challenge. The 300,000 pictures cover a period containing great social changes, but they carry next to no information to the future. A great majority of them are anonymous and my initial research questions evolved around how a cultural historian could use this as research material (Aspers, Fuehrer \& Sverrisson 2004).

Gunnar Lundh founded and built his business during a long time and he organized his images according to needs he discovered with his customers in different categories. The categories were labelled with metadata which composed a search way into the photographic collection. The label "Women" has several sub-categories, for examples "Women in the wind" and "Working types". The categories changed with time, some, like the category "Agrarian" was most active during the about ten-year long partnership with Ivar Lo-Johansson, while "Italy: shadows" contains only a few. 
The contact sheets, made of beige light cardboard, can hold as many as 40 pictures, which are glued to the sheets in the same order they appear on the negative roll. ${ }^{4}$ All in all, the collection of contact sheets amounts to about 10 000. The information on the contact sheets differs over his active years as a photographer. Generally, during the early years, the information was more substantial, providing knowledge about when and where-sometimes even with a name of the individuals portrayed, thus also covering the who-part. Further down the lane, the annotations on the contact sheets became routine and brief, sometimes not providing any more information than the year-and sometimes not even that.
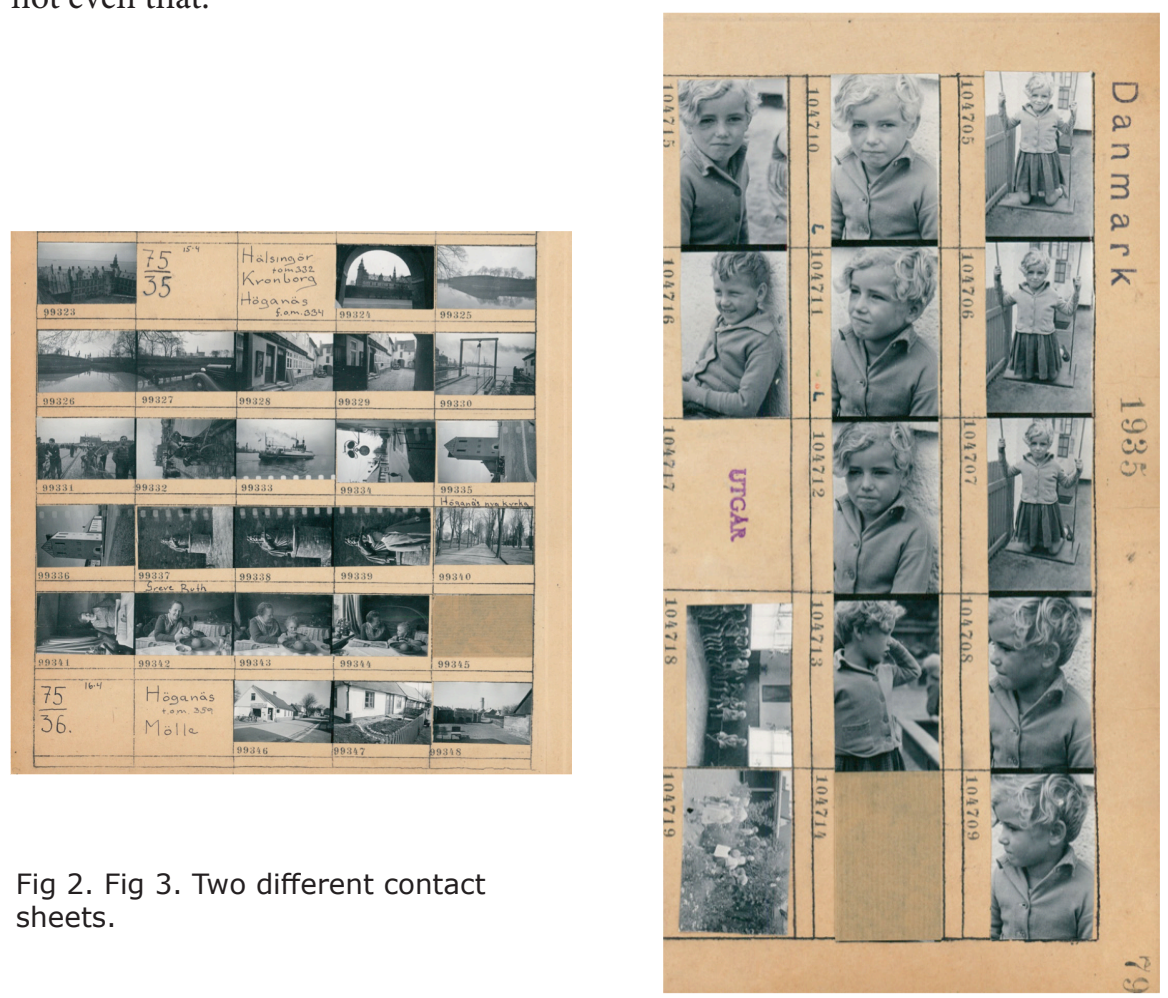

Fig 2. Fig 3. Two different contact sheets.

The contact sheets can be used as a path through the life of Gunnar Lundh, but they also work the other way around. By following the photographic trail, it is also-to some extent-possible to borrow the eyes of the individual and see what he saw. The individual lives her or his life in society, in a specific culture, and is surrounded by a world together with other individuals. Nevertheless, society can also be traced in the lives of the individuals (Ambjörnsson, Ringby \& Åkerman 1997: 8-9). This dualist relationship is a way into material that is otherwise silent, or mute. 
No matter how well documented a life is, only shards, bits and pieces remain of what was once a vibrant person, with purpose, memories, feelings, actions and ideas. For any historian, these slivers are what remains and what can be used to access a past (Douglas \& Mills 2018, Petersen 2007: 24). Even if the Gunnar Lundh archive is well stocked with photographs, they are next to anonymous. By adding biographical knowledge, it is possible to read the photographs. In this, I am using the art historian Joan M. Schwartz's ideas about functional context $(1996,1995)$ :

[---] photographs are documents, created by a will, for a purpose, to convey a message to an audience. To understand them as the product of actions and transactions, either bureaucratic or socio-cultural, we must return them to the action in which they participated. It is their functional context that transforms photographic images into archival documents.

In her texts, Schwartz describes how she has used diplomacy to approach photographic collections. In short, she illustrates how she, initially, needed to choose paths that led her away from the motifs and focus instead on issues discussed within the field of diplomatics, such as conventions, protocols and formulae. These have traditionally been used to study and determine the authenticity of diplomas and official charters, as well as increase understanding of the processes of document creation, information transmission and relationships between content and "reality" (Duranti 1989, Edling 2004, Bringéus 1990). With this, Schwartz could begin to place photographs (or perhaps rather photographic collections) in different contexts, contexts they otherwise lacked. I found this way of approaching Gunnar Lundh's photographs a rewarding way to process the "silence" that surrounded most of his photographs; it led me first away from the photos and then back again. The study of how to read different archival materials is not only a study of how to read a "text" but also a study of how context can be added to different personal archives.

My first task was to find a way to reach the individual behind the photos, and by combining Schwarz's functional context and a biographical method, the photographs revealed themselves in-not a new-but different light. By using the life span thematic, my goal is to show how time, ideas, ideals, things and individuals are in constant motion, that is, the conditions and the practical space an individual has at her or his disposal is not constant during a life span. This can, of course, also be seen as a typical microhistorical approach; both the individual and the structural perspective will shed light on the living conditions for the photographer during this period. The microhistorical approach will make it possible to challenge the general history of this time. Simply put, this means 
"asking large questions in small places", to quote Charles Joyner (Joyner 1999: 1, Svensson 2006: 25-26). The biography of Gunnar Lundh is more than just the basic facts like education, work, relationships, and death; it portrays his experience of these life events-through his photographs.

\section{Archival Slivers}

Researchers working with historical source material often use metaphors about their work with collecting and analysing the material, metaphors like trying to lay a puzzle with many pieces, or working with fragments, shards or traces (Harris 2011, Steinrud 2008: 33-34, Nilsson 2000: 21, Lennartsson 2001: 26). Although these metaphors are, in many cases, outworn and filled with platitudes, they are still operative. Working with historical source material, doing fieldwork in the past and analysing documents or other analogue material is often initially experienced as moving around in a fragmentary world, where the pieces will hopefully be joined together, thus engendering a bigger picture. It is important for the researcher to acquire as much knowledge as possible about the context from which the source material he/she is using has emerged. To gain knowledge about the time period in focus is equally crucial. Keeping both the individual and structural perspective in the research process is what constitutes the research process (Svensson 1993: 60, Telste 1993: 57, Lundgren 1990: 45-47, Frykman 1977: 16-24). In this process, it is not possible to know what kind of information every archival sliver will bring to the research, which makes it difficult to discard traces before they are found (Planck \& Steinrud 2017).

This wide and eclectic research process required me to choose paths in and around the source material that sometimes lead me away from my initial research question. This meant that I needed to move away from the photographs and motifs and rather focus on adding other types of documents, often from archival institutions other than the one in which the photographer's archive is kept. The biographical method, in other words, took me firstly into the world of the photographs of Gunnar Lundh, secondly away from them and his photographic business and, thirdly, back again.

Besides the photographs, a wide range of source material has been used to map and recreate the life of Gunnar Lundh. The most evident source material consists of information from various public records, such as church records, national registration, school records and taxation information as well as newspaper articles and literature he himself had written. Through different kinds of censuses, details emerge of his early travels and sojourns abroad-where he, mostly in Denmark and Germany, studied and worked as a photographer between the wars. People around Gunnar Lundh were also followed in the same way: his parents, siblings, 
some relatives and friends. His father's business was especially in focus, since it could shed light on his early years as a photographer and his childhood as part of a family business (Olsheden \& Olsson 1967, Ranby 2013).

In his personal business archive, some written documents describe the business he had built as a photographer. The correspondence between Ester Lundh and Nordic Museum after his death chronicle a situation where the museum was to take what they wanted from the mutual home of Ester and Gunnar Lundh at Döbelnsgatan 35 in Stockholm and arrange for the disposal of the objects they did not want to take to the museum. ${ }^{5}$ Many of the photographic instruments were incorporated into the collections, and the photos (negative rolls, contact sheets and photographs) and a smaller amount of written documents ended up in the archive, according to the idea of separating objects from documents (Hedström \& King 2004). The written documents reveal some information about his business and his ideas about how to run it, but they are predominantly financial documents. The majority of the documents in the archive are photos: negative rolls, contact sheets and pictures arranged in different categories. ${ }^{6}$ His life was also put into context by using the fate of other photographers active during the same period, and in some cases, individuals who met Gunnar Lundh in person were traced and interviewed. ${ }^{7}$

By following an individual throughout her or his life and building knowledge of their individual fate, the different types of materials in the archive can be put into context and are thus able to, so to speak, break the silence. The study of how to read different archival materials is not only a study of how to read a "text" but also a study of how context can be added to a personal archive. In this constant reciprocation between the individual and the structure, the photographer and his (in this case) life can be found. I will show an example of how the biographical knowledge of Gunnar Lundh in turn increases the ability to interpret his, mostly anonymous, images.

\section{Finding Voices: The Case of the Disappeared Girl}

Gunnar Lundh was active at a time when photographs became more common in people's lives. Having been a once in a lifetime event, mostly reserved for the affluent, it had now become available for the great majority of people. Pictures and images have always been an important part of human communication, even more so when the medium became more accessible (Sparrman, Torell \& Åhrén 2009: 12-13, Rittsel \& Söderberg 1983). Working with visual culture, close to the images, will add context to the archive as a whole as well as to the pictures themselves. One of the key notions is one of visuality, which focuses on questions concerning what 
is made visible, who sees what, as well as the connection between seeing, knowing and power (Hooper-Greenhill 2000: 14). Approaching the large photographic collection of Gunnar Lundh with these perspectives, the images are put into focus. Seeing and understanding or analysing the photos are two different ways to approach the images. Every photograph is a reference to a "reality", to something that is or has been, a reflection of time and space. In order for the interpretation of a photograph from a past to be as credible as possible, it is necessary that it is placed into a relevant historical and cultural context (Arvidsson 2009: 183-184, Rydén 2006, Burke 2001: 30-32).

Gunnar Lundh depicted numerous people. In the vast majority of cases, they are anonymous. The information on the contact sheets differs during his active years as a photographer. Some faces return on a regular basis. They age, and some get married and have children. Life is documented in various ways in the photographs. One of the faces that recur among the pictures is a blond girl in a curly pageboy haircut. There are never any annotations about where the pictures are taken or who it is. This is another silence in the archival material. Every so often she pops up, sometimes alone, sometimes with what could be her family, surrounded by perhaps her mother and siblings, sometimes alone. In the contact sheets, it is possible to follow her from a small toddler to a teenager during the 1940s. Then she disappears and from the 1950s onwards and is not to be found in the contact sheets or among the photographs in the Gunnar Lundh archive.

Following the photographic trail of her early life, it is clear that she is someone close to the photographer. She means something to him. Is it possible to figure out who she is? Is there a way to approach the photographs to unveil its secrets? Is it possible to see more in the pictures of the blonde girl than is, at first, visible to the naked eye? Will more information about the photographs of the girl change the visual experience of the photographs?

I approached the photographs of the girl with a four-way method, or possibly a four-way perspective is closer to the actual way I worked with the photographs and the motifs. Finding the girl among all the contact sheets was the first, basic and primary task. Working my way through the nearly 10000 contact sheets, running through the small photographs looking for the now so well-known face and characteristic airy blonde hair. Even though I thought I was thorough, I missed her several times, and working my way through the contact sheets numerous times proved necessary. Like all research based on archival sources, this was time consuming and patience-testing, but it left me with a solid base consisting of the photos of the girl and useful knowledge of the photographer's life as it was told through his contact sheets. His travels, recurring individuals, preferred motifs and different assignments and missions were made visible when walking through the trails of his life. 
Mapping all the information from the contact sheets about the photographs of the girl made it possible to see when he met her and the number of photos he took of her. This was difficult since the information is scarce. Overall, the only information that could be found was the year the photographs were taken. In general, this is not surprising. Our photographer was not particularly generous with information about the different photographs. What can be expected when going through the contact sheets is the year and, in most cases, where the photographs are taken, but the last is not valid for those he took of the blonde girl. Instead, the surrounding photographs can be used as a clue to where he was located, at least approximately. Looking at those taken before the ones with the blonde girl and those he shot after will in some cases give some useful information. Mostly, he seems to meet the girl in Denmark, or in the south of Sweden. In some cases she seems to be in Stockholm, judging by the surroundings. Nevertheless, it is interesting that there is so much silence around the photos of the girl. The amount of photos of her contradicts this silence and in many cases enhances the silence and makes it louder than in other cases in the contact sheets.

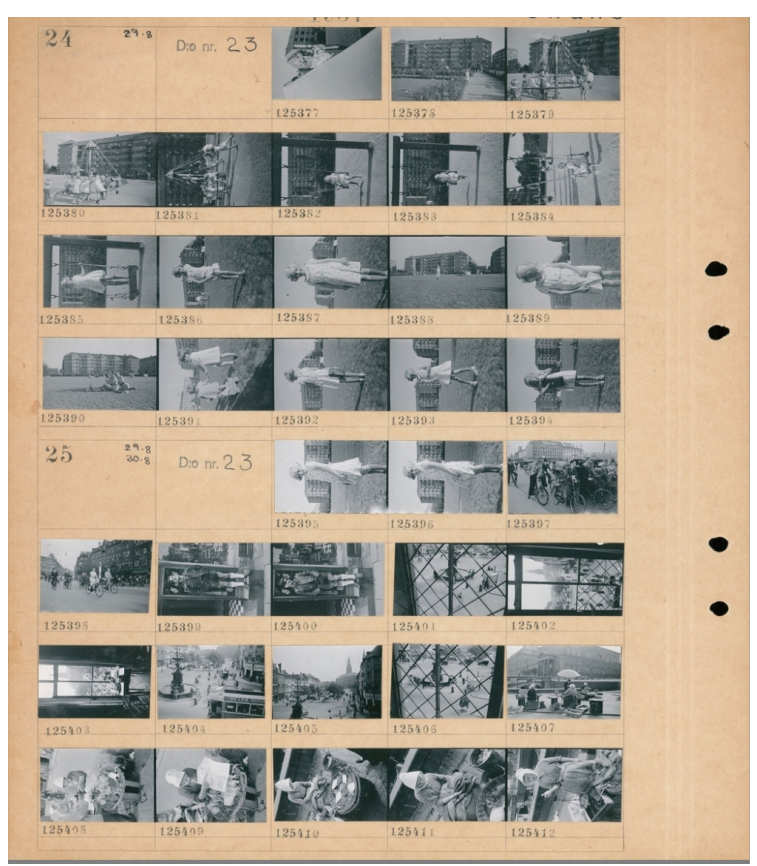

Fig 4. Contact sheet with "Skåne" and then nothing but obviously he is in Copenhagen. 
The second perspective is to establish the centre-periphery in the motifs, to look beyond what the photographer wanted the observer to see, further away from where the sharp part of the image takes the observer (Bringéus 1990). What did he want us to see and what did he consider to be less important, forming a background to the motif? Where, geographically, are the photographs taken? Is it possible to unveil the location? Some of the photos are easy to locate, for example, the city of Copenhagen, outside Tivoli. The girl is smiling, primary school aged, looking away from the photographer; her gaze disappears in the distance. She is holding an ice cream. The sun is shining. It looks like they are on an outing. Perhaps it is the amusement park that is the goal of their trip?

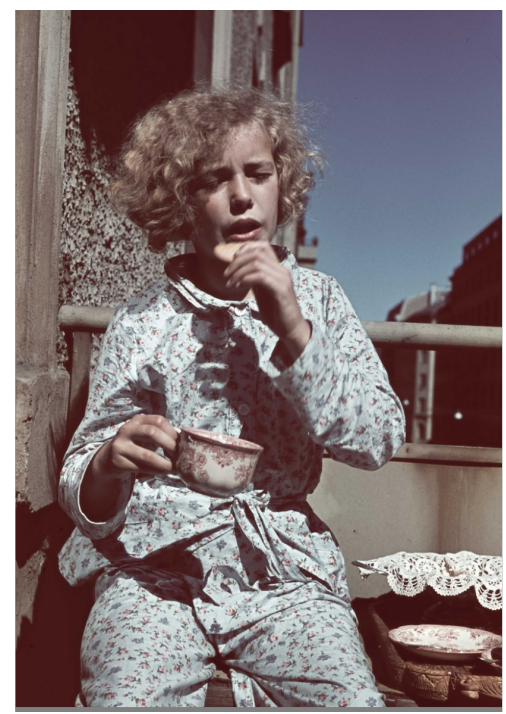

Fig 5. Picture of the balcony at Döbelnsgatan 35.

A couple of years further down the lane, the girl is older, possibly in her early teens. She has the same haircut, and it is easy to recognise her, since she and the photographer regularly met, at least according to the contact sheets. She wears a light blue floral pyjamas and her hair is a bit in disorder. She is just about to take a bite of a biscuit and is holding a cup in her right hand. Like most children, she seems to be more focused on chewing and wrinkles her face toward the sun rather than keep track of her cup-it leans a bit. In the background there are houses and the rail of the balcony, but also the façade of the house, where both the colour and the ornaments are visible. This small sliver of information provides us with information enough to point out that the place must be the balcony belonging to the apartment of Gunnar Lundh at Döbelnsgatan 35. The view reveals parts of Rådmansgatan, a crossroad to Döbelnsgatan. The light is coming from the east; perhaps it is morning and she is having breakfast on the balcony? 
The background of the photographs provides meaningful information in the puzzle that hopefully will bring us closer to the story of the girl in the pictures. In one of the pictures, she is sitting outside, at a white garden table; she is writing a postcard holding a pencil in her right hand. She is leaning over the table, pinching her eyes against the sun. In the background is the sign of Gunnar Lundh's parents' business, "Turistmagasin" the sign should say (Ranby 2013). In the following pictures, she is putting the postcard in the mailbox. The girl also appears in pictures with the family of Gunnar Lundh: his parents, his sister. In

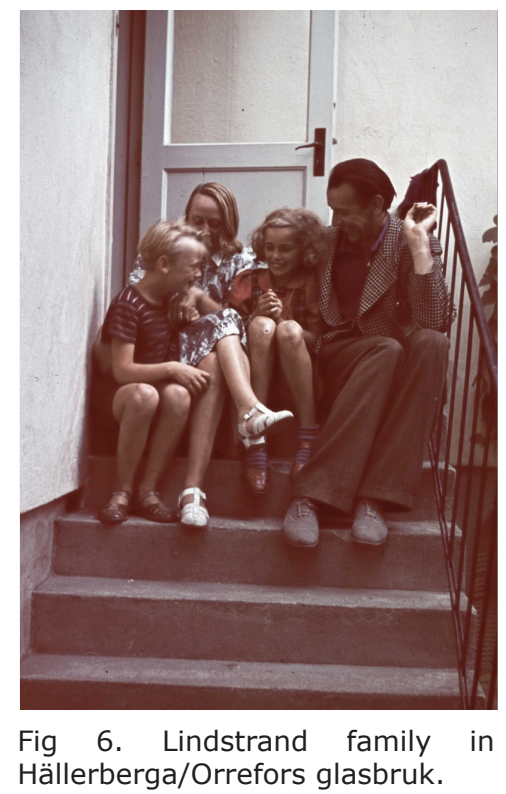

some photographs, she is modelling with a scarf or with a fish-pot over her head and face. In some pictures she is smiling and playing with the props; in others she is looking away from the camera lens, with a serious almost sad face. In one of the photographs, a middle-aged woman can be seen holding the fair-haired girl's hand. The girl has the fish-pot over her face and is smiling and perhaps laughing. She is looking in the same direction as the woman. The woman is not a stranger; she is one of the recurring faces among all the people in the contact sheets. She shows up early among the photographs; with neat and handsome writing her and her husband's names have been written on the contact sheet, and later so is their son Ola's. The woman in the picture is actress Kristina Lindstrand, between 1929 and 1946 married to the artist Viktor Emanuel "Vicke" Lindstrand. She seems to be quite familiar with the girl, as well as the rest of her family. The family is pictured on the staircase to their home in Hälleberga where Vicke Lindstrand was working at the Orrefors glassworks in 1928. The persons around the girl can also bring important pieces of information that will be of help in solving the puzzle; this is the third perspective with which to view the material. 


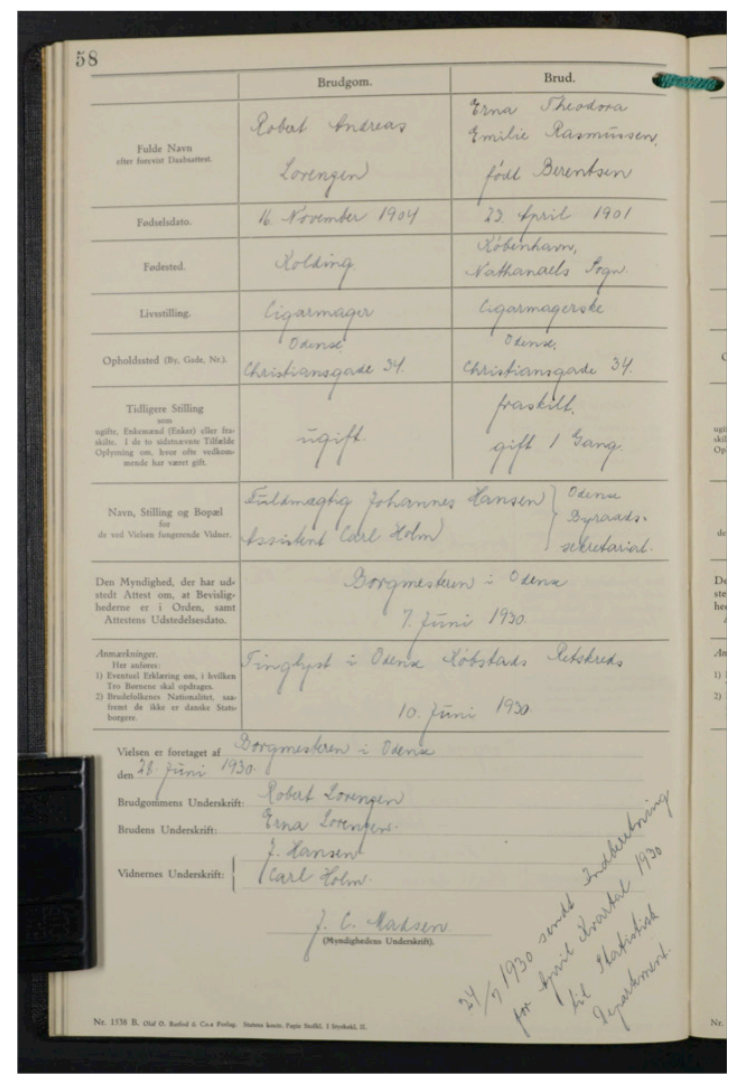

Fig 7. Marriage records.

In the last will and testament of Gunnar Lundh, the first piece of information about him having a daughter shows up. Since children born out of wedlock did not inherit from their fathers at this time, her presence in the will is one of the few remaining public traces of their relationship. The information in the will makes it possible to trace his daughter, Jytte, who at that time was married and living just outside Copenhagen.

In 1929, Gunnar Lundh became the father of a girl, Jytte. The mother was Erna Theodora Emilie Rasmussen (née Berentsen), from Denmark. ${ }^{8}$ She chose to give birth anonymously, which was possible in Denmark at this time. She later retracted her anonymity, and this makes it possible to follow Jytte's childhood. Erna Theodora Emilie Rasmussen married Robert Andreas Lorenzen when Jytte was about one year old. ${ }^{9}$ Gunnar Lundh never lived together with his daughter and her mother. Jytte grew up with her mother, stepfather and siblings, both older and younger. From the written documents, it is not possible to say anything about Gunnar Lundh's and Jytte's relationship. She is barely mentioned in the remaining 
documents in the archive, and this only when the organisation of their household is mentioned. ${ }^{10}$ Pictures of the home at Döbelnsgatan 35 over the years show no traces of anyone else living there apart from Ester and Gunnar Lundh. There are no guest rooms, not even a spare bed that could function as a place dedicated to Jytte. ${ }^{11}$ What the photographs can tell us is that he regularly visited her and her family in Denmark, and that she sometimes spent time with his parents in Höganäs or with him in Stockholm. She met his friends, and she must have been very far from the secret she seems to be in the written information of the archive.

Among the photos of Gunnar Lundh, a large number of pictures depict Jytte. The pictures constitute a photographic trail, where a daughter's presence in her father's life can be traced. Judging by the frequency, their contact seems to have declined during the latter part of the 1940s. Perhaps the war and the fact that she was growing up worked against their relationship, or perhaps he entered a new stage in life when he married in 1943.

Knowing who the girl in the picture is, and adding up the puzzle pieces, can another pattern appear? I started to see new things in the pictures, and accordingly interpreted the motifs differently. Moving from text to context and back again added further dimensions to the interpretation of the photographs. Finding Jytte was also finding more voices in the archival material, uncovering more plausible stories (Burke 2001: 32-33).

\section{Memory Lost and Found}

It is not clear what exactly was brought back to the museum from Ester and Gunnar Lundh's apartment, and following the correspondence between Ester Lundh and the museum officials, it is obvious that she had little or no knowledge of what finally was incorporated into the museum collections. Any documentation describing the process was never produced and it is not possible to know what the considerations of the museum were when-and if - they chose documents and object. Have any documents been disposed of, and if so, which and why? Why the photographs were added to the collections in the first place is also unknown. ${ }^{12}$ What we do know is that the museum contacted Gunnar Lundh when his father passed away, exploring the possibility of a donation of his photographs to the museum. ${ }^{13}$ It seemed like he turned them down, and in the end the photographs of Peter P Lundh ended up at Höganäs museum. Perhaps the enquiry laid the foundation for an idea Gunnar Lundh had early on to involve Nordiska museet in saving his photographs.

The accounts of the story behind the archive, the persons in it and behind it, are lost. Slivers of information are to be found in different archival collections, and together these pieces will help build a context and help in analysing the content. 
To create a perspective of ones own is a part of the research process, establishing a perspective of one's own. However, since this is information researchers need to know to help them work with the content of the archive, the information needs to be available, when it does not, the researcher needs to unveil it, over and over again. For every new sliver found, the archive is changed, expanded and magnified. Voices in the previously silent material can be heard and more stories can be added to the already known (Ernst 2008: 30-33, 65-69). This is a dialectic relationship and a cumulative process; the more one knows about the life of Gunnar Lundh, the more the content in his archive can be accessed. Furthermore, the more we know of the archive and the photographs in it, the more we learn about the photographer, his life and the period during which he was active.

When collecting archival slivers, bits and pieces and trying to join them together to form answers to both old and new questions, other stories from the source material emerge. These stories were not the centre of attention but still make and form the red thread of long-lost life stories. One of these stories is close to Gunnar Lundh and his daughter Jytte. Astor, the older brother of Gunnar, left Höganäs to attend Lund University the fall semester of 1913. He broke some kind of record, and in just three semesters managed to win a baccalaureate in literature and economics and stayed one extra semester studying political science with excellent grades. ${ }^{14}$ The life of Astor Lundh takes place just outside the more public life of his brother, although he, just as his brother, took photographs and even entered and won some minor photographical contests. ${ }^{15}$ He later moved to Stockholm, worked in libraries, and was active in different political and artistic organisations. Sometime around the early 1920s he met Alva Jakobsson, who was working as a salesclerk. In late August 1922 their daughter, Ulla-Britta, was born. ${ }^{16}$ The father recognised Alva as his daughter, but the couple never married or lived together. Traces of their relationship are visible in the photographs of Gunnar Lundh. There are some photographs of the three of them, together with a handful of photographs taken of Ulla-Britta. When Astor Lundh passed away in August 1970, children born out of wedlock still did not inherit from their fathers, even if the father had recognised the paternity. He was in other words in the same position as his younger brother a decade earlier. A year before Astor Lundh passed away, he arranged for an amount of money to be bequeathed to the mother of his daughter, his daughter and granddaughter in his last will and testament. ${ }^{17}$ One conspicuous difference is visible between the two cases of children born out of wedlock: whereas there is virtually no information about the daughter of Gunnar Lundh, Jytte, in the contact sheets, the names of both Alva and Ulla-Britta are carefully written down in connection to every contact copy. This together with 
information in wills and testaments, probate inventories and memories the traces of both Alva Jakobsson and her daughter Ulla-Britta are possible to follow. This story cannot be found using only one of the source materials available. In this case, the sum of the parts will be higher than what the parts can individually bring.

These pieces of information are lost memories in a personal archive that is silent or mute. I have argued that the personal archive of Gunnar Lundh is silent or mute. However, a biographical approach to the photographic material can operate in the area in between text and context, joining them together and enabling the documents to speak; it allows them to be heard-to be found. The process of adding context to an archive is a negotiation of the past, a negotiation that will contribute new dimensions in our collective memory, and also generate new, additional archives. There are, in other words, options other than silence, and the inevitable reversion and degradation into oblivion for those silent, or mute, personal archives in focus here. A biographical method can however operate in the area between text and context, joining them together and thus letting the material speak.

Marie Steinrud is a cultural historian at Stockholm University and Nordiska museet. Her research interests cover elites, identities, gender, manifestations of power and biography as method. Since 2016 she has been active as a researcher in the project Images and Stories of Everyday Life (Vardagens bilder och berättelser) and her on-going research project focuses on actors and actresses and experiences of shopping in eighteenth-century Stockholm. Her publications include a wide range of journal articles and book chapters on micro-history and cultural history, manifestations of power, elite status, elite women's lives and experiences in eighteenth-century and early nineteenth-century Sweden, as well as masculine ideals within nineteenth-century upper-class culture and elites and identities. Email: marie.steinrud@etnologi.su.se

\section{Notes}

1 The photonegatives are physically stored in different places, keeping them separate from other document is due to the dangers of cellulose nitrate.

2 The information about the life of Gunnar Lundh derives from church records, tax records, census records, probate inventories and records from Svenskt biografiskt lexikon (bind 24) at Riksarkivet, hospital records and newspaper articles.

3 Diariet, Ämbetsarkivet, NMA.

4 In some cases, the order has been reversed compared to the negative roll.

5 Diariet, Ämbetsarkivet, NMA.

6 Some of the pictures were exposed to water entering the archive facility due to heavy rains in the summer of 1988. The damaged photographs were dried and are still a part 
of the archive, stored separately from the others but still arranged in the same way the photographer once labelled them. (Archive after Gunnar Lundh, NMA.)

7 Four different individuals were interviewed: three men and one woman. Worth mentioning is that all of them were children or young adults when meeting Gunnar Lundh.

8 København, Sokkelund, Rigshopitalet sogn, Kirkebøger, Kirkebog 1929-1930, fødte kvinder.

\section{References}

\section{Archival records}

\section{Sweden}

Nordiska museets arkiv (NMA):

Archive after Gunnar Lundh

Stockholms stadsarkiv (SSA):

Stockholms rådhusrätt

Kungsholms församling

Stockholms läns landstings arkiv:

S:t Eriks sjukhus

Lunds universitet ( $L U)$ :

Filosofiska fakultetens arkiv

Helsingborgs stadsarkiv (HAS):

Höganäs församling

Väsby församling

Helsingborgs stads församling

Helsingborgs rådhusrätt

Region Skåne, regionarkivet:

S:t Maria sjukhus

\section{Denmark}

Rigsarkivet

Rigshospitalet sogn, fødte kvinder 1929-1930

\section{Literature}

Ambjörnsson, Ronny, Per Ringby \& Sune Åkerman (1997): “Inledning”, in Att skriva människan. Essäer om biografin som livshistoria och vetenskaplig genre, Ronny Ambjörnsson, Per Ringby and Sune Åkerman (eds). Stockholm: Carlssons bokförlag, 7-16.

Arvidsson, Maria (2003): "Fotografi som empiri. Att använda fotografier som historisk källa", in Visuella spår. Bilder i kultur- och samhällsanalys, Anna Sparrman, Ulrika Torell and Eva Åhrén (eds.). Lund: Studentlitteratur.

Aspers, Patrik, Paul Fuehrer \& Árni Sverrisson (2004): "Introduktion", in Bild och samhälle. Visuell analys som vetenskaplig metod. Patrik Aspers, Paul Fuehrer \& Árni Sverrisson (eds.). Lund: Studentlitteratur. 


\section{Culture Unbound}

Journal of Current Cultural Research

Batchen, Geoffrey (1999): Burning with Desire. The Conception of Photography. Cambridge, Mass.: MIT.

Berger, Stefan (2013): "The role of national archives in constructing national master narratives in Europe," Archival Science, 13, no. 1, 1-22.

Bringéus, Nils-Arvid (1990): "Bilden som etnologisk kunskapskälla", in Bilden som källa till vetenskaplig information, Allan Ellenius (ed.), pp. 125-150 . Stockholm: Kungl. Vitterhets-, historie- och antikvitetsakademien.

Burke, Peter (2001): Eyewitnessing. The Use of Images as Historical Evidence. Ithaca, N.Y.: Cornell University Press.

Carter, Rodney G.S. (2006): "Of Things Said and Unsaid. Power, Archival Silences, and Power in Silence", Archivaria, no. 61 (Spring), 215-23.

Derrida, Jacques (1996): Archive Fever: A Freudian Impression. Chicago: University of Chicago Press.

Douglas, Jennifer \& Allison Mills (2018): "From the sidelines to the center. Reconsidering the potential of the personal in archives", Archival science, no. 18 , $157-177$.

Duranti, Luciana (1989): "Diplomatics. New uses for an Old Science”, Archivaria, no. 28, 7-27.

Edling, Christofer (2004): "Visualisering i samhällsvetenskapen", in Bild och samhälle. Visuell analys som vetenskaplig metod. Patrik Aspers, Paul Fuehrer \& Árni Sverrisson (eds.). Lund: Studentlitteratur.

Eriksson, Gunnar (1997): "Att inte skilja på sak och person. Ett utkast till en biografisk metod", in Att skriva människan. Essäer om biografin som livshistoria och vetenskaplig genre, Ronny Ambjörnsson, Per Ringby \& Sune Åkerman (eds). Stockholm: Carlssons bokförlag, 103-120.

Ernst, Wolfgang (2008): Sorlet från arkiven. Ordning ur oordning. Göteborg: Glänta.

Farge, Arlette (1989/2013): The allure of the archives. New Haven, CT: Yale University Press.

Frykman, Jonas (1977): Horan i bondesamhället. Lund: Liber Läromedel.

Hedstrom, Margret \& John Leslie King (2004): On the LAM. Library, Archive, and Museum Collections in the Creation and Maintenance of Knowledge Communities. OECD-rapport.

Harris, Verne (2011): "Archons, aliens and angels. Power and politics in the archive" in The future of archives and recordkeeping. A reader, Jennie Hill (ed.), 103-122. London: Facet.

Hobbs, Catherine (2001): "Personal Archives. The Character of Personal Archives. Reflections on the Value of Records if Individuals", Archivaria, no. 52 (Fall), $126-135$.

Hooper-Greenhill, Eilean (2000): Museums and the Interpretation of Visual Culture. London: Routledge.

Joyner, C. W (1999): Shared Traditions. Southern History and Folk Culture. Urbana: University of Illinois.

Kozloff, Max (1993): “Det Privilegierade ögat”, in Jan-Erik Lundström (ed.) Tankar om fotografi. Stockholm: Alfabeta.

Kross, Walter (1955): Ebendige Leica. Das Bild-Lehrbuch der Leica-Fotografie. 120 beispielhafte Aufnahmen von Leica-Fotografen in aller Welt mit belehrendem Text. Frankfurt am Main: Umschau Verlag.

Lennartsson, Rebecka (2001): Malaria urbana. Om byråflickan Anna Johannesdotter och prostitutionen i Stockholm kring 1900. Eslöv: Brutus Östlings bokförlag Symposion.

Lundgren, Britta (1990): Allmänhetens tjänare. Kvinnlighet och yrkeskultur i det svenska postverket. Stockholm: Carlssons.

Mason, Kären \& Tanya Zanish-Belcher (2007): "Raising the Archival Consciousness. How Women's Archives Challenge Traditional Approaches to Collecting and Use, Or, What's in a Name?", Library trends, no. 2 (Fall), 344-359. 


\section{Culture Unbound}

Journal of Current Cultural Research

Mölleryd, A. W. (1958): "Gunnar Lundh. Höganäspojken som blev internationell elitfotograf”, Nordvästra Skånes Tidningar, Höganäs Tidning (19581007).

Nilsson, Bo (1984): “Gunnar Herbert Lundh", in Svenskt biografiskt lexikon, b. 24, p. 308. Stockholm.

Nilsson, Fredrik (2000): I rörelse. Politisk handling under 1800-talets första hälft. Lund: Nordic Academic Press..

Olsheden, Jan and Stellan Olson (1967): Vad gjorde farfar i Mölle? Stockholm: Norstedt.

Petersen, Anja (2007): På visit $i$ verkligheten. Fotografi och kön i slutet av 1800-talet. Eslöv: Brutus Östlings förlag Symposion.

Planck, Brita \& Marie Steinrud (2017): "Eliters privata brev som mikrohistorisk källa", Historisk tidskrift, no. 3, 463-474.

Ranby, Caroline (2013): Kongl. hoffotograf Peter P. Lundh. Det bästa ljus och nutidens bästa instrumenter. Höganäs: Höganäs museum.

Rehnig, Jeanne E. (1999): Das "Photographische Atelier" im Warenhaus. Fotografie bei A. Wertheim (1898-1933) und Wolf Wertheim (1909-1914). Würzburg: Bayerische Blätter für Volkskunde.

Söderberg, Rolf \& Pär Rittsel (1983): Den svenska fotografins historia: 1840-1940. Stockholm: Bonnier fakta.

Rydén, Reine (2006): "Hur skall vi använda bilder? Ett bidrag till diskussionen om bilder som historiskt källmaterial", Historisk tidskrift, no. 3, 491-500.

Sandweiss, Martha A. (2007): "Image and Artifact. The Photograph as Evidence in the Digital Age", Journal of American History, vol. 94, no. 1, 193-202.

Schwartz, Joan M. (1995): “We make out tools and our tools make us'. Lessons from Photographs for the Practice, Politics, and Poetics of Diplomatics", Archivaria, no. $40,40-74$.

Schwartz, Joan M. (1996): "Visual Literacy. Returning Image Content to its Functional Context," in the session "Are Archivists Literate?" Annual Meeting of the Society of American Archivists, San Diego, California, 31 August 1996.

Schwartz, Joan M. and Terry Cook (2002): “Archives, Records, and Power. The Making of Modern Memory" Archival Science, no. 1-2, 1-19.

Sparrman, Anna, Ulrika Torell \& Eva Åhrén (2009): "Vild och kunskapssökande", in Anna Sparrman, Ulrika Torell \& Eva Åhrén (eds.) Visuella spår. Bilder $i$ kulturoch samhällsanalys. Lund: Studentlitteratur.

Steinrud, Marie (2008): Den dolda offentligheten. Kvinnlighetens sfärer i 1800-talets högreståndskultur. Stockholm: Carlssons bokförlag.

Svensson, Birgitta (1993): Bortom all ära och redlighet. Tattarnas spel med rättvisan. Stockholm: Nordiska museets förlag.

Birgitta Svensson (2006): "Utan stora berättelser finns inga små', in Axess, no. 5, 25-26.

Telste, Kari (1993): Mellom liv og lov. Kontroll av seksualitet i Ringerike og Hallingdal 1652-1710. Oslo: Avdelning for historie IKS, Oslo universitet.

Thomas, David, Simon Fowler \& Valerie Johnson (2017): The Silence of the Archive. London: Facet Publishing.

Digital resources and databases

Folkräkningen 1900, 1910, 1920, 1930, 1940, 1950, 1960

Sveriges befolkning 1860-1940

Sveriges dödbok 1860-2017

Rotemannen, Stockholm 


\title{
The Contract-labour Photographs of Gunnar Lundh. A Media History Study of a Photo Archive in Motion
}

\author{
By \\ Maria Bäckman
}

\begin{abstract}
The focus of this article is the work of photographer Gunnar Lundh, specifically the works collectively known as the statare photographs, images of rural contract labourers (or statare) that form part of a collection donated to the Nordic Museum in 1961. An overview of how these photographs have circulated in the Swedish public sphere indicates that three areas are particularly suitable for a targeted study of their use and reuse: i) social reportage, aimed at the miserable conditions facing these agricultural labourers in the emerging welfare state; ii) a biographical theme, in which the contract-labour photographs are part of a historical layer that repeatedly connects the author and opinion former Ivar Lo-Johansson with the 'contract-labour photographer' Lundh; and iii) how the older images remain a relevant element of a contemporary material cultural-heritage creation. In all of these examples, Lundh's contract-labour photographs function as visual models through which it becomes possible to represent the contract labourers' historical reality in books, buildings and interiors. However, they also constitute important components in the creation and perpetuation of what this article highlights as a distinctive set of intra-referential memory.
\end{abstract}

Keywords: Photography, Archive, Media history, Intra-referential memory, Contract-labour, Gunnar Lundh, Ivar Lo-Johansson.

Bäckman, Maria: "The Contract-labour Photographs of Gunnar Lundh. A Media History Study of a Photo Archive in Motion", Culture Unbound, Volume 12, issue 1, 2020: 36-64. Published by Linköping University Electronic Press: http://www.cultureunbound.ep.liu.se 


\section{Introduction}

Thanks to the major donation to the Nordic Museum in 1961, the work of photographer Gunnar Lundh is almost uniquely well-documented. In all, the museum has some 300,000 photographs by Lundh in its archive. As a young photographer in 1920s Berlin, Lundh came into contact with the new photographic techniques made possible by $35 \mathrm{~mm}$ compact cameras. The small, handy camera manufactured by Leica allowed him to shoot in the moment, both in the city and the countryside. Although people were often the focus of these images, everyday chores are also a constant presence. The photographs preserved in the archive are often in the form of series, with identical or similar motifs varying in quality. Gunnar Lundh was a working photographer from the 1920s until his death in $1960 .^{1}$

This article discusses Lundh's contract-labour photographs with an emphasis on how this body of images has circulated and been re-mediated in diverse contexts, by different stakeholders and for a variety of purposes. This reasoning links to recent history-of-media research that argues for the need for a broader, cultural-history influenced concept of media (Ekström 2004: 16 et seq.; Jülich, Lundell \& Snickars 2008: 12 et seq.; Cronqvist, Lundell \& Snickars 2014: 13 et seq.). In several concrete studies conducted in the field, media's materiality and pathways have also been granted considerable space (see, for example, Andén-Papadopoulos 2008; Gustavsson 2013; Nyblom 2014; Jülich 2015, as well as Ekström in this issues). It is this expansive media concept that constitutes the theoretical background for the following study of the origin, use, attraction and circulation of the contract-labour photographs.

As far as Lundh is concerned, there can be no doubt that the manageable compact camera verified media historian Anders Ekström's observation that the introduction of new means of representation, "opens the world up in a new way, introducing new possibilities for and limitations to how we arrange and display the world" (Ekström 2008: 43). However, the increased accessibility afforded by these new cameras in comparison to their more cumbersome predecessors not only widened the photographer's radius of action, it also improved their ability to identify possible motifs (cf. Rittsel \& Söderberg 1983: 261, 270 et seq.). The Leica made other images possible to capture, opening the way for another kind of photographic vision. With its significantly cheaper film, this new technique also allowed the photographer to take a great many more pictures.

One overarching question posed by the Nordic Museum's project Images and Stories of Everyday Life-which provides the framework for several of the texts in the current issue of Culture Unbound-deals with finding methods that pave the way for exploring larger pictorial collections of the type represented by the Nordic Museum's Lundh collection. The intention is therefore to conduct both empirical 
observations of the material in question and to use it as a basis for formulating more far-reaching analyses of the photographs, the collection and the archive as an institutional environment. In this sense, the project joins the broader discussion on photography as a source of knowledge regarding historical conditions, as well as a visual tool that individuals and groups have been able to utilise to achieve various goals in their own era.

For reasons that will be explained in greater detail later in the article, I have chosen to focus on Gunnar Lundh's images of contract labourers and farm workers, consisting of approximately 2,000 photographs. ${ }^{2}$ Even now, however, it can be noted that it is these photographs of contract labourers, mostly taken during the period 1937-1945, for which he has subsequently come to be best known. Neither is it insignificant that he took the majority of these photographs in collaboration with author and opinion former Ivar Lo-Johansson.

\section{Who were these Contract Labourers?}

Contract labourers were agricultural workers employed year-round, primarily in southern Sweden and the Mälaren Valley from the mid-eighteenth century until the system was abolished in $1944-45 .^{3}$ Until as late as 1926 , Swedish contract labourers were subject to a series of Servant Acts. They had one week off (known as slankveckan) at the end of October between annual periods of employment, during which the contract labourer could change their job or employer. Their wages were largely paid in kind, in the form of accommodation, food (such as milk, potatoes, rye, wheat, peas), as well as a small sum of money. Unlike farm workers and milkmaids, contract labourers were generally married with families. Their contract often included the services of their wife, for example in milking cows. The population of Sweden increased dramatically during the nineteenth century. This was especially true of those without property, and the economic chasm between the landless and landowners widened at the same time as the desire grew at central government level to rationalise the agricultural sector. As a result of this confluence of events, the number of contract labourers also increased during the nineteenth century, reaching its highest level at around the turn of the century, when the group consisted of 41,900 individuals. By 1943, a couple of years prior to the abolition of the system, the number of contract labourers was calculated at $16,700 .{ }^{4}$ Although similar organisational forms have existed in other countries, this combination of year-round employment and extensive payment in kind (including accommodation and assumed marriage) gave the Swedish contract labourer a special character from an international perspective. Finally, the Swedish contract-labour system is distinguished by its institutionalised form and the fact that it survived in large-scale agricultural production until the end of World War II (Lundh \& Olsson 2008: 14 et seq.). 
By the end of the nineteenth century, contract labourers and the contract-labour system were increasingly seen as an anachronistic remnant of the past. Living in a strictly patriarchal environment, they were also late in unionising, only doing so as the system was dissolved to be replaced by a cash economy. Compared to almost all other groups of workers in society, they had limited freedoms and lived in substandard conditions. Thanks to the authors that came to be associated with them-primarily Ivar Lo-Johansson, Moa Martinsson and Jan Fridegård-during the first half of the twentieth century, the contract labourers became a heavily symbolic literary motif.

The most widely disseminated of the contract-labour photographs look something like this; in brief, they are generally represented as an agricultural proletariat bordering on serfdom or servitude. Commonly employed on large estates or farms, they worked under harsh, sometimes inhuman, conditions for nothing more than board and lodging. Not only that, but the accommodation provided was cold, cramped and for the most part crawling with vermin.

\section{Gunnar Lundh: The Contract-labour Photographer}

During the early decades of the twentieth century, considerable debate raged concerning the vulnerable situation of the contract labourers. Not least, Ivar Lo-Johansson played his part in the work that, during the 1930s and 40s, finally led to the abolition of the contract-labour system in 1945. His books - both novels and short-story collections-were mass-printed in cheap editions that reached a wide readership and he also wrote pamphlets and debate articles in various newspapers. Among other things, he was a frequent contributor to the Swedish Agricultural Workers' Union's newspaper Lantarbetaren. However, photographer Gunnar Lundh was also a central figure in this work, capturing images and creating a visual, documentary form for the social reportage written by Lo-Johansson. A prominent example is their influential photo reportage book Statarna $i$ bild (Images of the Contract Labours) (1948), to which I will return later in the text.

By trialling various approaches, the project Images and Stories of Everyday Life is intended to inspire new means of exploring existing collections. My own choice has been to focus on the contract-labour photographs that to such a large extent have contributed to retrospectively defining Gunnar Lundh as a photographer. Many of these images can reasonably be described as photographic icons; that is to say, they are part of a severely restricted set of images that are recurrently used to illustrate themes such as contract labourers, agricultural workers, Swedish labour reforms or simply rural life in general (cf. Hariman \& Lucaites 2007; Strandroth 2007: 77 et seq.). 
The donation to the Nordic Museum also includes material from the photo agency Gunnar Lundh ran from his Stockholm home from the mid-1930s onwards. This agency material offers an insight into how Lundh himself categorised his work. However, the almost total lack of explanation of the contexts for Lundh's pictures is a significant obstacle. The only available information often consists solely of the year in which the photo was taken, sometimes the place and, extremely rarely, a note of who or what activity is being depicted. This means that we seldom know the purpose behind Lundh's photographs; did he take the pictures because he had a desire to portray a particular contract labourer, or did he happen to be cycling past when he saw a good subject-his handy compact camera always at the ready?

Even if Lundh's many contract-labour photographs are well-known and widely disseminated, they remain strangely anonymous in the archive. How does one study such contextless and, in that sense, mute photographic material? Can we even say with any certainty what the photographs depict? Is it the contract labourers' existence, that is to say, the day-to-day life of a contract labourer? Or are the photographs actually an expression of artistic vision and, if so, whose? Gunnar Lundh's or Ivar-Lo-Johansson's? Are they an expression of political ambition - or, perhaps, even agitation? Are they images of a stain on Sweden's history? Or simply a photographic representation of what today appears to be disturbingly antiquated and musty living conditions endured during a period of frantic modernisation?

In other words, there are many questions associated with the contract-labour photographs as an archived collection. In fact, it is even difficult to categorise or define what is actually meant by a Gunnar Lundh contract-labour photograph. The first of these pictures was taken in the early 1930s and the last one after the abolition of the contract-labour system in 1945. Certain early images were captured on his own initiative, perhaps while cycling through the districts around the Skåne villages of Arild and Mölle, where he ran photographic studios together with his father and siblings, and worked during the summer, while some are clearly the result of joint reportage expeditions undertaken with Lo-Johansson. Others have been published in other contexts, such as themed issues of the magazines $V i$ (1937) and Folket $i$ Bild (1975: 3) that focused on contract labourers. ${ }^{5}$ So, at least some of the material seems to have arisen directly from paid assignments. Below, I shall initially dwell on one of the images often associated with Gunnar Lundh's work as a photographer of contract labourers.

\section{The First Holiday}

As pointed out in the introduction, one significant feature of the Nordic Museum's Lundh collection is that it seems to contain an almost complete lifetime's worth of photographs. Unlike many other photo collections, here it appears that all of the photographer's images have been preserved, including negatives and contact 
sheets, providing us with access to not only published photos but also to a wealth of material that was not deemed suitable for commercial use. It is also often possible to discern that published photographs are part of a longer series all with the same subject, raising the important issue of selection. With regard to the contract-labour photographs, however, we know very little about the context in which this occurred; was it Gunnar Lundh himself who made the selection or perhaps Ivar Lo-Johansson, or was it an editorial decision prior to the completion of the work in question? One simple example may illustrate the difficulty in linking a photo opportunity to a given author.

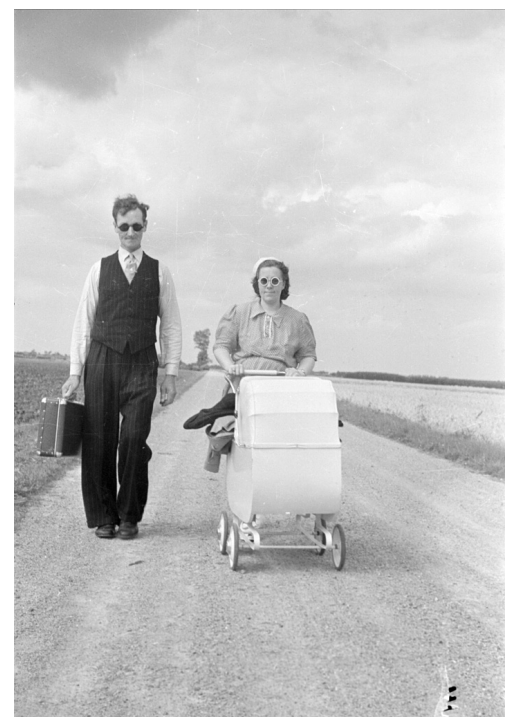

"Den första semestern" (The First Holiday) is one of Gunnar Lundh's most famous photographs. When this is used in historical overviews or other printed/digital media, it is normally said to depict a young couple, contract labourers, on their way home from their first holiday, enjoyed in conjunction with the introduction of statutory paid holidays in 1938 (Rittsel \& Söderberg 1983: 274; cf. enter "semester" [vacation] at Swedish Wikipedia; see also Larsson in this issue). This image of the carefree young couple with a pram wandering along a sunlit gravel road in sunglasses, the man clutching a small suitcase, has thereby come to symbolise the newfound freedom represented by this new statutory leave, not least for agricultural workers, who suddenly found themselves with two weeks of paid annual leave. It appears that, on this sunny summer's day at the end of the 1930s, Ivar Lo-Johansson and Gunnar Lundh happened to catch sight of this homebound couple, happy and rested after what was perhaps their first ever holiday. Gunnar Lundh then captured this iconic image, according to Lo-Johansson upon his own urging. 


\section{Culture Unbound}

Journal of Current Cultural Research

But there is more to be said about the matter, as pointed out by antiquarian and photo historian Eva Dahlman, the photograph was in fact not taken in 1938, but eight years later in 1946. Not only that, by studying the contact sheet that includes the picture, Dahlman was also able to ascertain that it was not a unique image captured in the moment, but rather part of a long series of photographs. The couple had been asked to pose, walk, stand still and walk again before Gunnar Lundh obtained the picture he was looking for (Dahlman 1993).

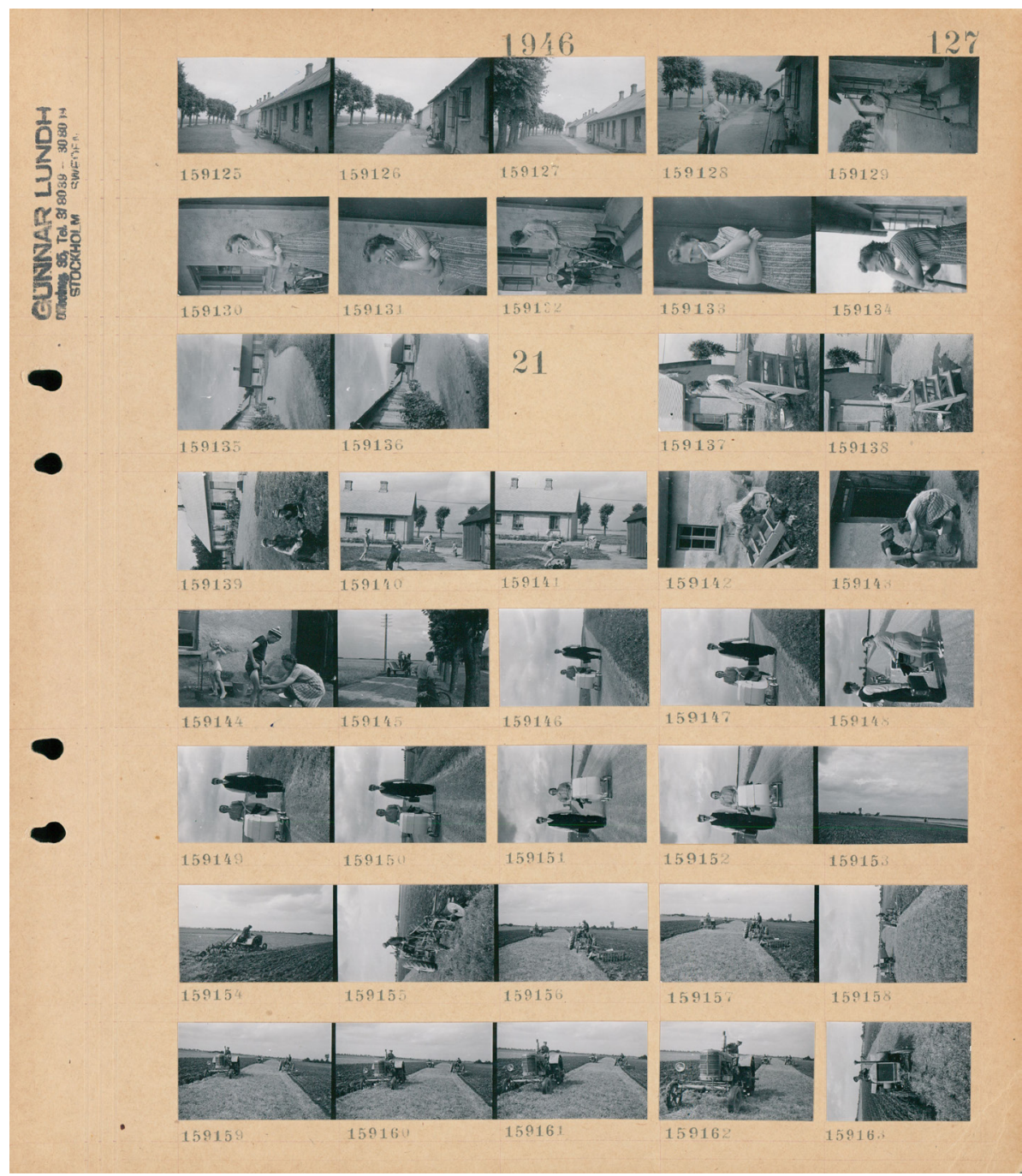


Ivar Lo-Johansson's own written account of the photographing of this relaxed and strolling contract labourer couple is, however, entirely different. In his version, the picture was taken immediately after the 1938 legislation on paid holidays. In his memoir Frihet (Freedom), he describes the bicycle tours of Sweden he undertook with Gunnar Lundh to report on contract labourers. Ivar Lo-Johansson is the first to glimpse the group, apparently making their way home from their holiday. "I just had time to call out to Gunnar Lundh, 'There they are. We threw ourselves from our bicycles and he just managed to take the photograph before they had time to stop" (Lo-Johansson 1985: 269 et seq., quoted by Dahlman 1993).

This dramatic account of the author's immediate insight into the photograph's importance is in stark contrast to the diligence with which the scene was directed in order to obtain the desired motif, as witnessed by the preserved contact sheet. It is however worth mentioning that Gunnar Lundh's famous photograph of the first holiday has been highlighted as either a lucky accident or the result of Ivar Lo-Johansson's sharp gaze. As Dahlman points out, this probably say something about how we value the work of photographers and other image creators in relation to text producers. Here, one could add that the episode also function as a strategic means to strengthen the image of Lo-Johansson as a man of many virtues, among them the capability to successfully extract an iconic picture out of a lazy afternoon.

If nothing else, this example demonstrates the importance of also studying the image's photographic origin. Although the photographs seldom give away any specific information about themselves, they can still provide us with useful knowledge. In fact, this is among the greatest benefits of the donated collection; because the original contact sheets, often with fully preserved series of photos, are available digitally in the Nordic Museum archives, it is unusually fertile ground for examining the more work-oriented aspects of Lundh's photography. As in the given example, by studying the contact sheets, Lundh the photographer may be suddenly revealed as possessing a clear directorial vision, while at other occasions he can be seen to exercise a profound sensitivity for capturing spontaneous moments in time (cf. Thorbech 1994: 132; Nilsson 1975: 95, 104).

\section{Circulation and Re-mediation}

In the end, the problem with the material's lack of wider context proved to be far from limited to a shortage of concrete information regarding its subjects, dates and purposes; it long appeared that the 'contract-labour photographer' Gunnar Lundh himself did not consider this group to be particularly relevant to his own craft. In Lundh's photo-agency material, carefully categorised and filed, often into subcategories (cf. Nilsson 1975: 94, 104), contract labourer is not even a category in its own right. However, after closer examination, a colleague and I identified 
individual images from the photobook Statarna i bild under the heading Agrarian. These could show up under categories and subcategories such as Ploughing, Oxen, Women, etc. Finally, we came across an archive box in which Lundh had collected his contract-labour photographs under the subcategory Agrarian: Agricultural labourer: Contract labourer. This is where he himself had chosen to place the pictures, interspersed with the subcategories Agrarian: Cowshed, Agrarian: Reapers and Agrarian: Milking Centre.

Given the lack of clarity with regard to the contract-labour photographs' complicated and drawn-out origins, I concluded that the only available opportunity to approach the collection lay in taking a step back. Instead of viewing the photographs as in-the-moment documents, it seemed considerably more rewarding to study the contexts assigned to them retroactively. This is similar in approach to Solveig Jülich's (2015) interest in another, more internationally renowned, Swedish photographer, Lennart Nilsson. Based on a thorough documentation of photographic material, photo sessions, assignments, publications and existing economic and publishing networks, Jülich has, among other things, followed the national and international circulation and re-mediation of Nilsson's photobook A Child Is Born.$^{6}$ For obvious reasons this method is linked to both what Appadurai and others have put forward as writing the social biography of objects (Appadurai 1988; cf. Mintz 1986) and the extensive research conducted over recent years based on various types of shadowing (see, for example, Latour 1988; Czarniawska 2007).

A further analytical point of entry to the place assumed by the contract-labour photographs in the public sphere is to research the selection processes prior to publication or other forms or re-mediation. Here, I would especially like to emphasise Leila Koivunen's (2009) discussion of the central role of the illustration in nineteenth-century British (written) travel accounts. Far from being involved in the same kind of colonial project, Gunnar Lundh's contract-labour photographs can nevertheless be likened to a somewhat similar documentary breakthrough into then relatively unknown and unexplored territory. Moreover, as we will see, the nexus of text and picture/photograph is very much a relevant factor when it comes to how the photographs have been circulated over time.

Based on a cohesive focus on the selection, use and dissemination of the contract-labour photographs, I have identified three areas that are, in my opinion, suited to targeted study of their use and reuse. First, there is the social reportage; second, we have a biographical theme; and third, there is the question of how the older images maintain their relevance through inclusion in a contemporary material cultural-heritage creation. In the latter context, Lundh's contract-labour photographs function as visual representations in an attempt to use buildings and 
interiors to capture the historical reality of the contract labourers' way of life. As we will see, the content and themes from these areas often move fluidly between categories.

\section{The Contract-labour Photographs and Social Reportage}

The initial and well-known impact was that the contract labourers, through social reportage, became part of the Swedish labour movement's struggle to create a socially sustainable folkhem, or home for the people. Against this background, the contract labourers constituted a problematic but useful example of a group that was yet to be included in the modern, forward-looking welfare efforts being made in the 1930s and 40s. In other words, images of the poverty endured by the contract labourers could be used to illustrate the need for political reform to improve the lot of a neglected social group (Hassner 1970, 1977; Nilsson 1996: 158). Like earlier documentations of the slums of Victorian London and the thirties Dust Bowl of the depression-era United States, Gunnar Lundh's images of Swedish contract labourers became a photographic tool for revealing the everyday misery in which many of the folkhem's inhabitants still lived (cf. Strandroth 2009). The photographs did more than simply describe or depict, they also demanded political action. Lundh's contract-labour photographs can therefore undoubtedly be incorporated into the documentary and critical photographic tradition
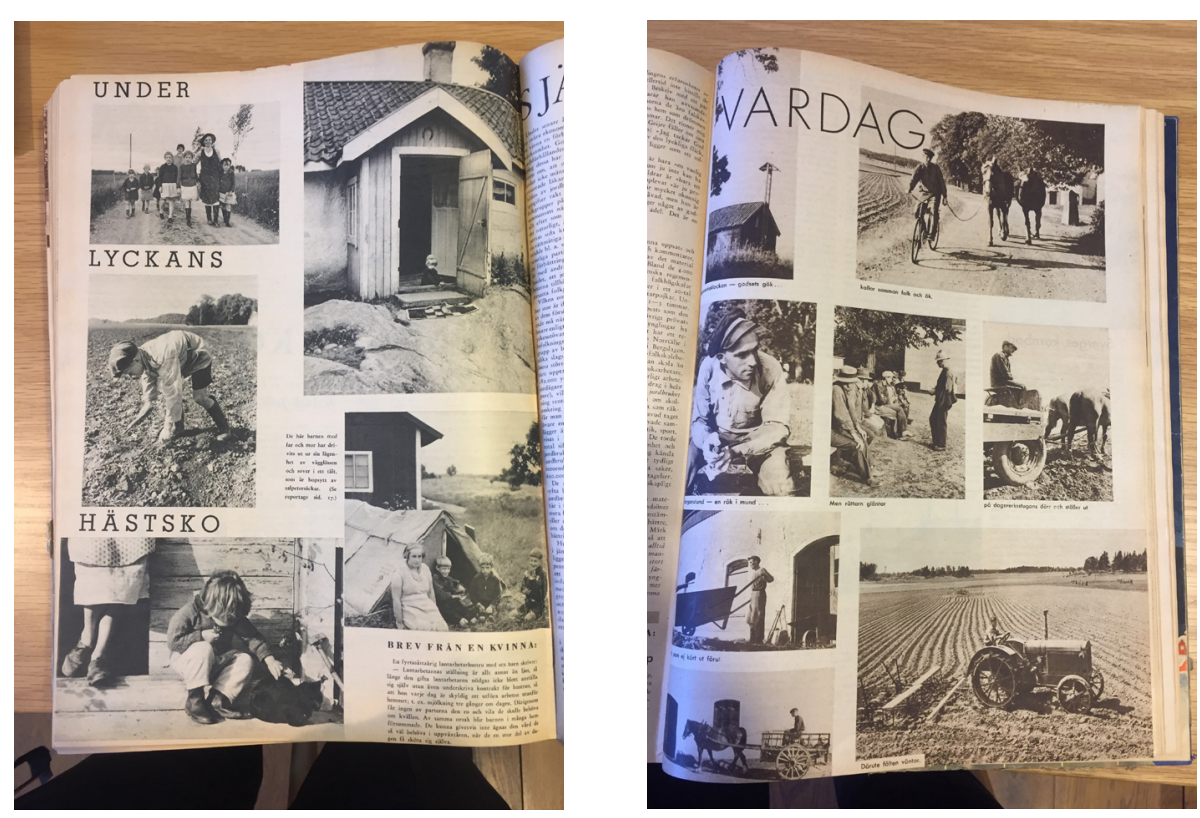
established in the US by the FSA Photographers. ${ }^{7}$ To no surprise, some examples of Gunnar Lundh's contract-labour photographs have been compared to Dorothea Lange's famous 1936 image "Migrant Mother" (Thorbech 1994; Gullers 2012).

In order for the contract-labour photographs to be truly effective, it was, however, necessary to furnish them with both text and context. As Roland Barthes (2007 [1970]) emphasises, the ambiguous nature of the images requires that they are provided with textual markers if they are to convey their intended meaning. The reportage published in $V i$ in 1937 can be seen as an example of how text and image collaborated to convey a clear message about the precarious position of the contract labourers to the magazine's readership. The photographs in these reports function either to illustrate articles dealing with the poor conditions under which the contract labourers lived (for example by showing and discussing inadequate housing), or to provide an insight into their everyday lives (in the form of photospreads with very brief explanatory texts).

It is this close connection between text and image that was further developed a decade later, when Lundh's documentary photographs and Lo-Johansson's social-realist descriptions of the contract labourers' existence came together in the photobook Statarna i bild (1948). The text in the photobook is allowed to expand beyond the limits imposed by the Vi photospreads without in any way dominating the photography. Lo-Johansson himself commented that his preferred method as a writer was to work through what he called social poetry: "Literature belongs to society. It is not imposed on society. This tendency is the morality of poetry" (Quoted from Reberg 2001:51). ${ }^{8}$ It is exactly this social tendency-i.e. its strategic choice of descriptions, narrative motifs and touching illustrations-that forms the basis for the visual design of Statarna i bild (cf. Dahlman 1993).

For those with access to the Nordic Museum's extensive collection of Lundh's photographs, it is obvious that the photographs published in the book represent a conscious choice intended to highlight certain aspects while excluding others. Therefore, in the photobook, there is little space for the joy, relaxation, larks and games to which the collected pictorial material in the archive also bears witness (cf. Hellspong 2004: 286f). It is not difficult to discern the presence of two people and two personalities; on one hand, the snapper Gunnar Lundh with his interest in day-to-day activities and proven ability to capture those spontaneous moments in flight and, on the other, author Ivar Lo-Johansson with his equally clear conviction of what was required to unequivocally convey the gravity of the contract labourers' hardships.

In years to come there would be a great explosion of photographs used in the growing mass market of picture magazines and the documentary photography book, both in Sweden and internationally. However, when Statarna $i$ bild was 


\section{Culture Unbound}

Journal of Current Cultural Research

published it was still very much a novelty. In fact, it was one of the very first examples of a purely social depiction to appear in photobook form in Sweden and its reception testifies to the fact that the public, to a certain extent, realised that they were witnessing a new phenomenon, although this did not prevent accusations of tardiness against the authors. ${ }^{9}$ In its review, national daily newspaper Svenska
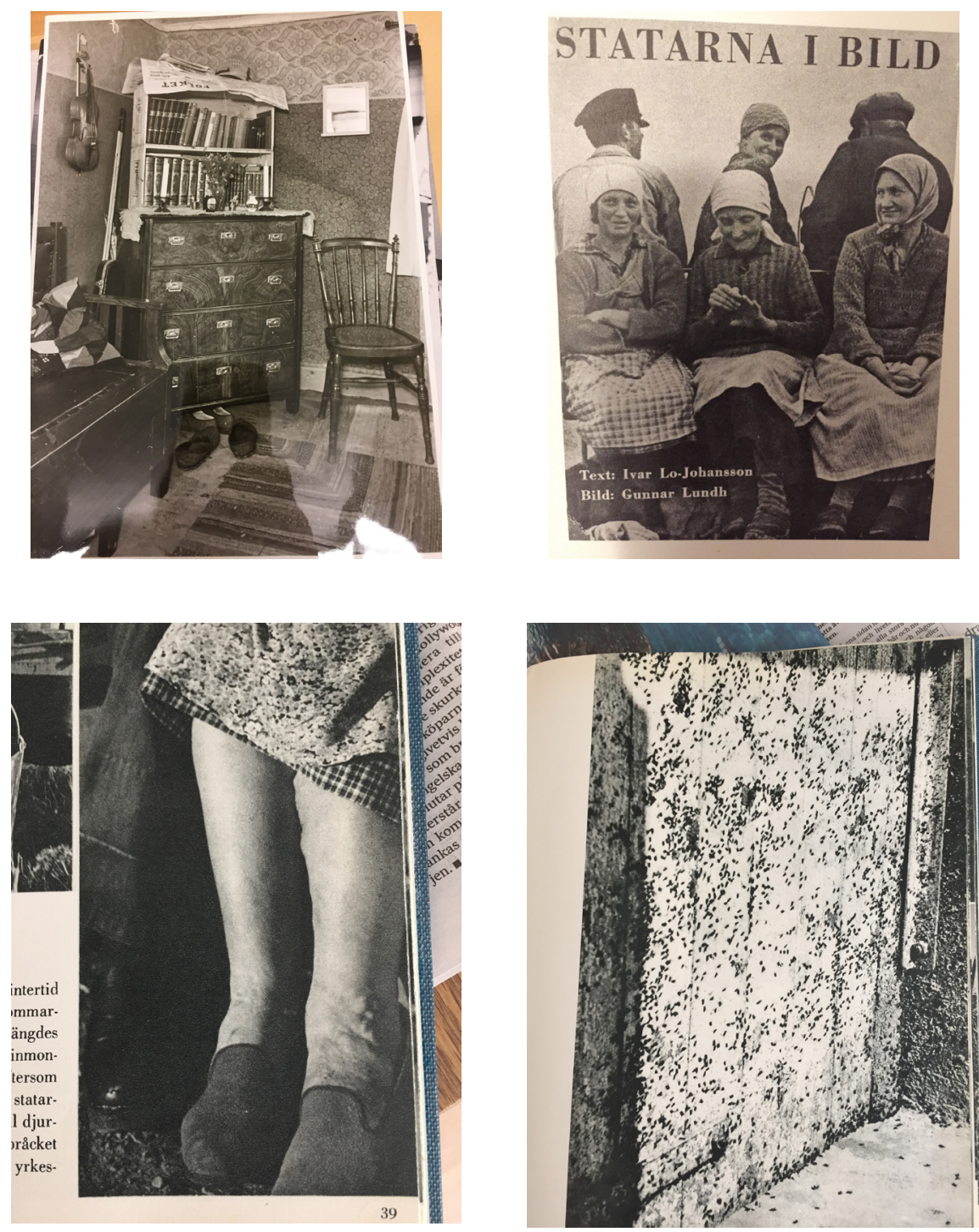

Dagbladet observed that it seemed strange that Lo-Johansson, as engaged as he was in the plight of the contract labourers, had not previously utilised the photographic medium, stating that, "the camera's unadulterated realism would 
have been invaluable in the struggle for contract labourers' rights". Nevertheless, given that it was now 1948 and the contract-labour system was a thing of the past, the reviewer felt that the book was more of a scrapbook of a bygone era. A couple of the photographs-the countless flies on the barn door and a moving wagon overflowing with possessions-were however highlighted as being particularly moving (source: Svenska Dagbladet 23.09.1948).

In retrospect, one can also state that Statarna $i$ bild has had an enormous impact in terms of which of Lundh's contract-labour photographs have continued to circulate and be re-mediated. Among these images, particular mention should be made of the photographs depicting threadbare homes; a bookshelf with a few books (known as the alter of culture); milkmaids; an old woman's varicose legs; the flies; and the creaking moving-cart, as highlighted by the contemporary reviewer.

These photographs recur in a variety of contexts and genres, including: biographies of Ivar Lo-Johansson; scientific articles; commemorative and anniversary texts; popular science journals; and as models for physical environments such as contract labourers' housing conditions or the staging of events such as moving home. The images constitute an illustration of the conditions described in the texts or of the author's contentions. It is nowhere near as common that the pictorial material in question is highlighted as photographic/artistic work in its own right; rather, this generally takes place in relation to Lo-Johansson. One example of a recurring theme is the descriptions of Lundh as Lo-Johansson's companion or photographer, clearly subordinate to the latter's political ambitions and desire for social change.

The contract-labour photographs' association with the social reportage is therefore linked to the rhetorical work that the photographs could perform contemporaneously, when they were relatively freshly taken. In this respect, they differ from how the images remain active in the creation of various retrospective projects. Firstly, one such important context is their use as historical testimony in the forming of the contract labourers as a part of Swedish cultural heritage. In other words, they are utilised as an important pedagogical tool in an ongoing use of the past (Aronsson 2004) with material signatures. Secondly, there is also a distinct biographical trail where the contract-labour photographs are a component of a historical layer that links the author and opinion-former Ivar Lo-Johansson with the photographer Gunnar Lundh and his familiar images of contract labourers. The remainder of this article will dwell on this multifaceted memory work; however, given the relationships between our three empirical fields, folkhemmet, modernity and social structures will inevitably be drawn into the discussion. ${ }^{10}$ 


\section{Mirroring Memories}

"Gunnar Lundh is a concept - the 'snapper' and 'contract-labour photographer' who collaborated with Ivar Lo-Johansson." These are the words that introduce a review of Gunnar Lundh's work in the Nordic Museum's yearbook Fataburen (Thorbech 1994: 124). It is with remarkably similar wording that Lundh is introduced in Den svenska fotografins historia (A History of Swedish Photography): "Gunnar Lundh (1898-1960) is primarily known as Ivar Lo-Johansson's photographer. Together, they conducted reportage that contributed to the abolition of the contract-labour system in 1944" (Rittsel \& Söderberg 1983: 270). Neither is there any doubt that Lundh the photographer is primarily associated with the contract-labour photographs that he published in collaboration with Lo-Johansson. However, as stated above, the reverse is also true.

Lo-Johnsson is usually claimed as one of the more powerful influences on the wave of public opinion that led to the final abolition of the contract-labour system in 1945 (cf. Furuland 1976: 190 et seq.; Oldberg 1964: 33 et seq.). To a large extent, it is also his literary, social-realist descriptions-the latter to a significant degree combinations of Ivar Lo-Johansson's texts with Gunnar Lundh's images-that have come to colour posthumous perceptions of the conditions that characterised the day-to-day lives of contract labourers. Lo-Johansson too can therefore be seen to be intimately associated with the contract labourers, the contract-labour system and, not least, with many of the photographs of various contract labourer environments taken by Gunnar Lundh in order to give visual form to Lo-Johansson's words. This close connection is noticeable in the manner in which the contract labourers, Lo-Johnsson and Lundh form a recurring triad in biographical or narrative contexts relating to the contract labourers and the contract-labour system, the photographer Gunnar Lundh or the author and debater Ivar Lo-Johansson.

In both informative, biographical and academic context, the contract labourers and/or the contract-labour system are generally described using visual aids in the form of Gunnar Lundh's photographs and with reference to Ivar Lo-Johansson's literary reform efforts. In the same way, it is convenient to refer to Lundh as the contract-labour photographer, while any biography of Lo-Johansson would be deemed incomplete without his role as the public voice of the contract labourers. Conversely, recollections of author and opinion-former Lo-Johansson are often linked to his efforts on behalf of the contract labourers, often illustrated by a photograph taken by Gunnar Lundh. Irrespective of the direction from which one approaches, all of the component parts of this triad are illuminated. In this sense, the contract labourers, Gunnar Lundh and Ivar Lo-Johansson can be viewed as a distinctive set of collective and intra-referential memory. That is to say, they are so tightly intertwined with each other that the pure mentioning of one of 
them inevitably evokes associations to the other ones. The concept of mirroring memories thus underlines that we are facing a multi-mediated memory work that encompasses and unites several different parties.

Lundh's entry in the Dictionary of Swedish National Biography (written by ethnologist Bo G. Nilsson) therefore quite rightly gives a prominent place to his association with the contract labourers and Lo-Johansson:

L was a socially observant photographer. His pictures of the Swedish countryside with men and women engaged in agricultural labour are well-known and in his depiction of the living conditions of contract labourers there are images that approach classic status. He has produced four photobooks. The book Statarna $i$ bild-undoubtedly his most important-was published in 1948. This documentary photo collection is the result of a fruitful collaboration with Ivar Lo-Johansson, author of the book's text. The book was issued at the time of the Swedish Agricultural Workers' Union's 30th anniversary. Since 1937, Ivar Lo-Johansson and L had undertaken reportage assignments in contract labourer provinces on behalf of a number of magazines.

The same applied when, in 1975, the Nordic Museum collaborated with Sveriges Radio on a joint 30th-anniversary publication to mark the abolition of the contract-labour system. Even in this commemorative publication, titled Statare. Statarklassens historia $i$ ord och bild till 30-årsminnnet av det sista statarlasset (Contract labourers-the history of the contract-labour class in words and pictures) (Furuland 1975), the preface returns to the combination of Gunnar Lundh, Ivar Lo-Johansson and the contract labourers:

The photographs are mostly the work of Gunnar Lundh, taken on his travels during the 1930s and 1940s with Ivar Lo-Johansson, who drew his attention to the importance of documenting the lives and conditions of the contract labourers.

So, Gunnar Lundh is not only a significant part of the common cultural memory and the representation of the contract labourers, he is also a participant in the representation of Ivar Lo-Johansson as the 'contract-labour author' (see also Reberg 2001: 22, 50). Those biographical presentations that emphasise the author's intimacy with the contract labourers as both a personal and political project are generally illustrated by a Lundh photograph, preferably depicting the pugnacious author standing in front of a moving cart, a farm labourers' cottage or astride a bicycle on his way to investigate the contract labourers' living conditions. It is hardly an understatement to say that these recurring images formed part of Lo-Johansson's early efforts to recreate himself as his own brand (cf. Liljestrand). 
Culture Unbound

Journal of Current Cultural Research
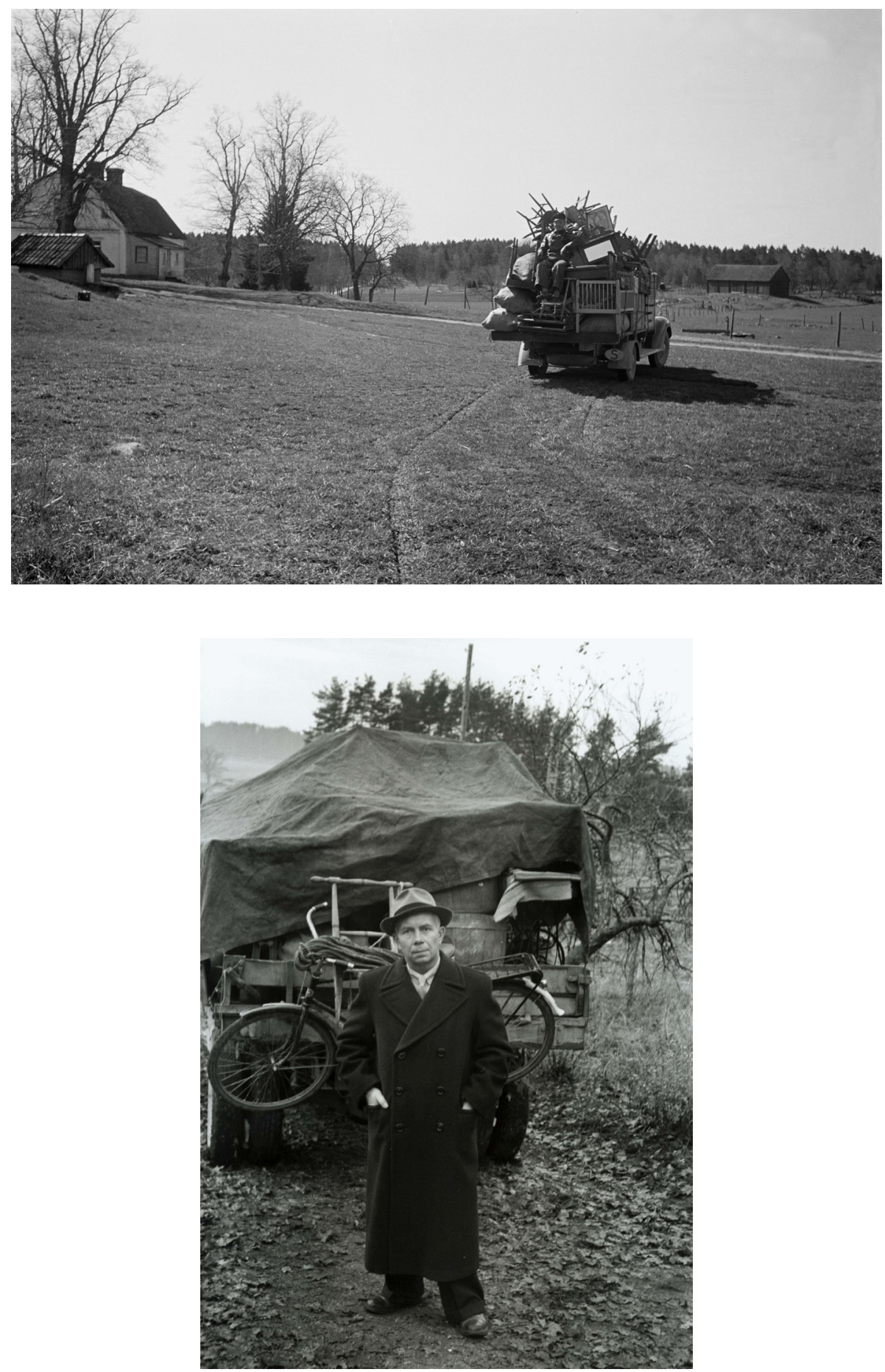
It is in this and similar ways that the intra referential memory continues to be constituted, reasserted and perpetuated with the aid of various printed media and genres. The active memory work is not, however, limited to words and images; it can also be traced through various built and staged environments in which it is part of an active creation of cultural heritage. Here, too, the close association between 'contract-labour photographer' Gunnar Lundh's iconic images, 'contract-labour author' and debater Ivar Lo-Johansson, and the contract-labour system and the contract labourers themselves is reaffirmed time and time again. In this materialisation, it is possible to follow how the contract-labour photographs now to a large extent live a life of their own away from the archival and literary models.

\section{The Berga Farm Labourers' Cottage}

There is a red farm labourers' cottage with white window frames in Skansen (Stockholm), the world's first open-air museum, consisting of two single-room homes with a common hallway and a larder for each family. The present location of the small house is due to a decision taken by the Nordic Museum and Skansen on the abolition of the contract-labour system, that it would be desirable to preserve an authentic farm labourers' cottage (Berg 1975: 5). ${ }^{11}$ Mats Rehnberg, then a curator at the Nordic Museum and later a professor of folklore/ethnology, was tasked together with Ivar Lo-Johansson with finding a suitable example. In 1949, a building was identified in the Parish of Åker in Södermanland that could be acquired on condition that the current tenants were allowed to remain for as long as they wished before the house was moved. This condition meant that the building was not finally transported to Skansen until 1966, on the death of the final tenant.

The left-hand home in the cottage was furnished as it was when the Carlsson family lived there between 1874 and 1924. In conjunction with the acquisition to Skansen, the Carlsson's grandchild was interviewed in order to document everything from the family's work and leisure activities to how their single room was decorated. The Carlsson's had only two children and the family never left the cottage, remaining there for fifty years, even after their retirement. According to their grandchild, they enjoyed life on the farm. This is something that is often highlighted by museum pedagogues who work in the cottage as some form of aberration that demands explanation. In the usual accounts of the contract-labour system, including those of Lo-Johansson, contract labourers were likely to have large families and to move on a yearly basis in search of better accommodation or more humane working conditions. The space inside this particular labourer's cottage provides a sense of calm and security, with a high made-up bed, a kitchen sofa that invites tourists to take the weight off of their feet, flowers in the windows, 
a ticking wall clock and a table with paraffin lamp. ${ }^{12}$ However, thanks to several own visits in the milieu, I also know that the fact that many visitors comment that the home seems pleasant and cosy is something the museum staff, when asked, find difficult to deal with; it shouldn't 'really' be pleasant in a farm labourers' cottage.

In clear contrast to this harmonious image of contract labourer life, the other home-which also lacks any link to a living family-is much more in keeping with the accounts of those such as Lo-Johansson, with a sleeping area for multiple children, threadbare furnishings, unwashed porcelain left out and beds with their legs in tins to hinder the progress of bedbugs. This is also the only environment within Skansen that is not kept neat and clean for visiting tourists. Interestingly enough, at least according to the museum staff at work in the cottage when I have been talking to them, it is also this more authentic environment that appears to be comparatively more appealing, as it does not chaff against expectations. Many visitors are taken aback when homeliness contradicts the obvious social misery which they are prepared to encounter when entering a farm labourers' cottage.

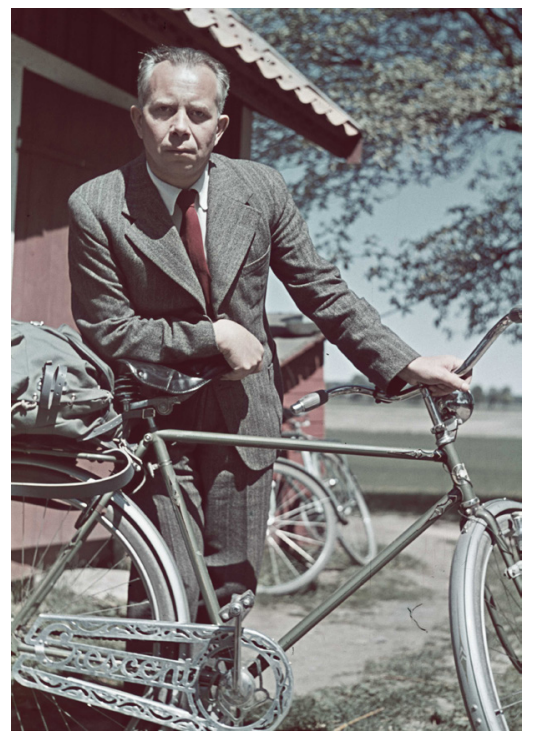

In a somewhat critical review of the image of contract labourers painted by Ivar Lo-Johansson's collected works on the theme, ethnologist Mats Hellspong confirms that it is Lo-Johansson's decidedly negative characterisation of contract labourer life that is usually given material form in museums (2004: 305). ${ }^{13}$ Using a number of examples from the photobook Statarna $i$ bild (1948), Hellspong demonstrates how the black and white photographs in the book are chosen to emphasise the negative aspects of daily contract labourer life. 
The strategic work to influence that forms the framework of much of Ivar Lo-Johansson's writings on contract labourers-and which is accentuated by Gunnar Lundh's social-realist images of women with varicose veins, families with hordes of children, steely-eyed labourers and overloaded moving cartstherefore has many similarities to the highly prevalent black poetry identified by Per-Markku Ristilammi (1994) in his understanding and descriptions of the Swedish million-home housing estates since the 1970s. Even against this background, Ristilammi confirms that this more positive view from the inside becomes somewhat problematical in that it chaffs against the expected representation. This is especially the case if the negative descriptions of the housing estate are at the same time the very catalyst that is expected to pave the way for social intervention and increased resources (ibid: 131f).

\section{Ivar Los Park}

There are, however, contexts in which the light and dark are seemingly permitted to exist side by side. Ivar Los' Park is situated on Bastugatan in Södermalm, Stockholm, directly across the road from the building that houses the two apartments in which Lo-Johansson lived and worked for most of his adult life. ${ }^{14}$ The park is hidden away behind a high red fence with a gate that opens up to reveal a panoramic view across the bay of Riddarfärden and central Stockholm. Aside from trees and shrubs, lawns and benches, the park contains a bust of Ivar Lo-Johansson and a themed playground.

For the purposes of this article, the themed playground is our primary interest. This consists of a number of houses, a barn, a grazing cow with calf, a horse and cart and a tractor; all solid timber constructions with realistic details, such as the leather harness hanging from a nail and the milk churn in the milking shed.

On the City of Stockholm website, you can read that the park has a rural theme, that is to say, the countryside, and that there are existing houses, interiors and a barn to explore. The idyllic, picture-book image of the 'countryside' created in the park is in stark contrast to the harsh rural life about which Lo-Johansson wrote. And yet, the themes given material form in the park's wooden sculptures and constructed interiors are easily recognisable. Here we find a number of markers for contract labourer life that Lo-Johansson and Statarna $i$ bild helped to bring to a wider audience; the animals, the milking and, not least, the tractor-the symbol of the future, of modernity and a beckoning freedom for the contract labourers.

Ivar Los' Park was officially opened in 1990 by former Social Democratic Minister of Finance Gunnar Sträng. In the description of the park, it is stated that Sträng shared the same rural-proletarian roots as Ivar Lo-Johansson, and that in his capacity as chairman of the Swedish Agricultural Workers' Union he contributed 
to driving through the abolition of the contract-labour system in 1945-following the trail blazed by writers engaged in the issue, such as Lo-Johansson ${ }^{15}$. The connection between Ivar Lo- Johansson and the contract labourers was, in other words, already explicit when the park was opened, and was further reinforced by the thematic construction of the playground, despite its idyllic appearance and the fact that the contract-labourer link was never stated.

The official opening of the park by the previous Minister of Finance also reveals one of the other common threads running through the contract labourer issue and the early labour movement. Sträng's own political career, taking him to a position as one of the twentieth century's most successful Social Democratic politician, is in fact part of this context. In 1932, he became an ombudsman for the Swedish Agricultural Workers' Union and was tasked with unionising both agricultural workers and contract-labourers. During the 1930s, he carried out this work by cycling around the countryside in the most contract-labour-intensive areas of Sweden. In 1939, Sträng was elected chairman of the Agricultural Workers' Union, primarily thanks to his ability to get to grips with the Union's financial disarray, although his successful enrolment of large numbers of new members was a contributory factor. This is generally described as a successful period for the Union; membership continued to grow and the working conditions of agricultural workers were significantly improved. In retrospect, Sträng's most acclaimed achievement in trade unionism appears to have been his participation in the abolition of the contract-labour system. During this period, Sträng came to the attention of the Social Democrats and the Swedish Trade Union Confederation and in 1945 he was given a ministerial post. Sträng's entry in the Dictionary of Swedish National Biography (authored by historian Anders L. Johansson) specifically states that it was the successes achieved by the Agricultural Workers' Union under Sträng's chairmanship that led to the perception of him as a rising star within the party.

\section{Images on Route}

Today, there is a noticeable ambition among a number of researchers to present a more nuanced picture of the contract labourers than the starkly negative image that is to a great extent supported by the combination of Ivar Lo-Johansson's words and Gunnar Lundh's photographs. Established notions such as the white whip' (for women's demanding daily milking work), 'horizontal tower blocks' (for the terraces of labourers' cottages) and the endless moving between jobs and homes; these all belong to the older estates and attempts are currently underway to break them down and reveal their complexity (cf. Hirdman 2012: 58). In the introduction to the book Herrgårdsromantik och statarelände (Manor House 
Romance and Sharecropper Misery) (2004: 17 et seq.), Karin Lindvall writes that the manor house environment has long been depicted in "dark colours" in newspaper articles and books dealing with issues related to farm labourers and contract labourers, highlighting the novels of Jan Fridegård and Ivar Lo-Johansson as the culmination of this period. According to Lindvall, a common and recurring emphasis on the manor house environment as a strict class society of subservience, oppression, great injustices and antiquated norms has taken its place in history as an undisputable fact. She, however, wishes to remind us that these numerous descriptions were part of a wider political debate that, aside from the issue of contract labourers and their conditions, also dealt with the representation of an overarching social democratic social ideal of welfare and modernity. Others point to the fact that newfangled technologies and industrial collaborations could have major local and regional consequences for the design of the contract-labourer system on the ground (Lundh \& Olsson 2008: 20 et seq.).

Lindvall's point is about how we understand the past. She contends that the images and narratives fashioned by Ivar Lo-Johansson and "his photographic companion" Gunnar Lundh regarding the contract labourers have entered history as "truer than reality and real memories" (ibid: 18). Reservations regarding unilaterally negative depictions of the heterogenous collective that the contract labourers may be said to have constituted mean that the common cultural memory is beginning to creak at the joints. For those who work with the use and reuse of the contract-labour photographs, the question therefore arises of what will happen to Gunnar Lundh's famous images in the future. Will it be possible to incorporate them into this new, critical orientation?

There is much to suggest that this will prove to be the case, which is hardly strange. The Nordic Museum's comprehensive collection of Lundh's photographs contains a wealth of material that has seldom, if ever, been published-for the simple reason that it did not fit snuggly into the overall framework constructed to highlight the privations and harsh realities of contract labourer life. However, as stated previously, the preserved photographs are entirely capable of telling stories about the contract labourers and the contract-labour system other than those to which we have become accustomed. One of the most recent works collecting contemporary research on contract labourers, the anthology Statarna - i myt och verklighet (Contract labourers-In Myth and Reality) (Lundh \& Olsson, ed. 2008), is intended to problematise some of the main features of the accepted view of the contract-labour period in Sweden. Here too, a number of Gunnar Lundh's photographs are used. So, it would be no surprise to find Lundh's pictorial material being recycled in other representations aimed at correcting, nuancing or broadening the "depiction of misery" that has to such a great extent been based on his own photographs. And possibly this will also be the case with many of his 


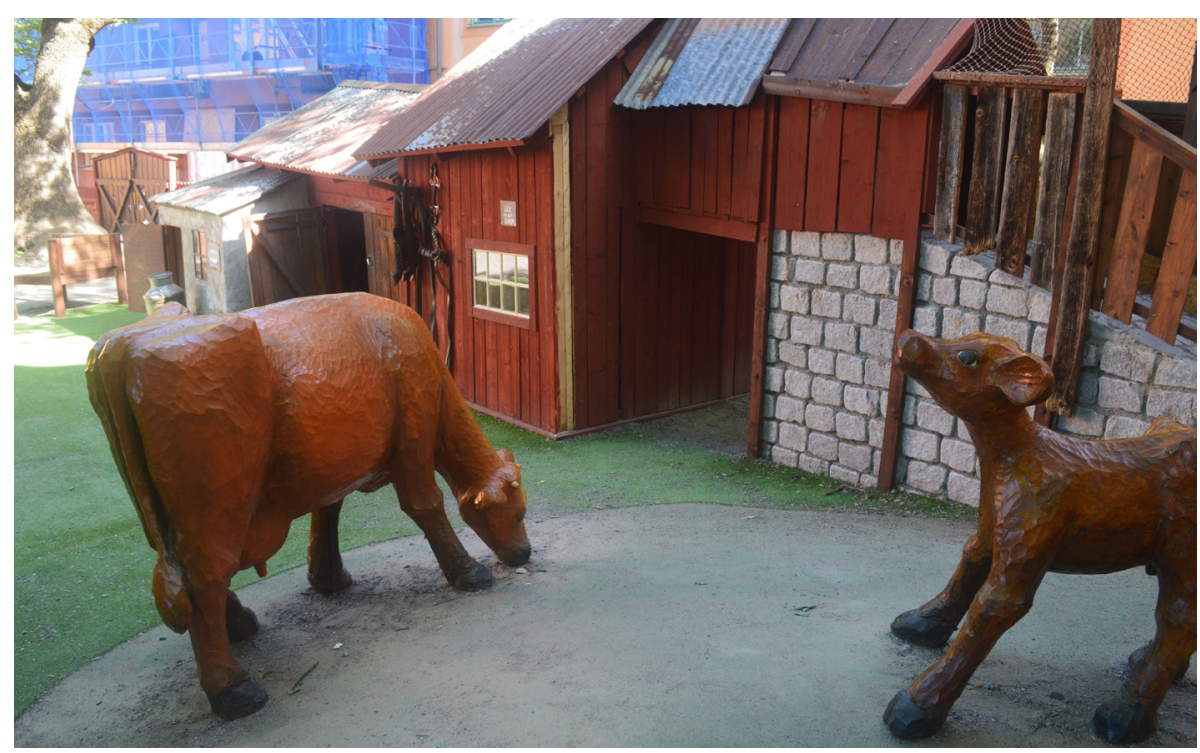

Photographer: Vidar Ekström.

already iconic images; perhaps these too will continue their successful circulation? Despite everything, their message is of course not set in stone in the photographs themselves-it arises in the communicative stream that runs between the pictures, their context and the viewer.

The article could be rounded off with this remark; however, at the same time, the just-mentioned anthology demonstrates that the contract-labour photographs' circulation is unsuited to overly schematic analyses. One of Lundh's photographs used in the book's chapter on contract labourers' housing (ibid: 169), depicting a group of children and youths in front of a white, half-timbered house, can be viewed as a conscious repost to the traditional view so often expressed in reportage published in Vi and Statarna $i$ bild, with its cramped accommodation and shabby interiors. On viewing this rarely published photograph, we find ourselves far from Lo-Johansson's characterisation of terraces of labourer's cottages as "horizontal tower blocks". Other images are less easy to sort according to such a contrasting logic.

The anthology's cover image depicts six people, four women and two men, sitting on what seems to be a horse-drawn cart. The photograph has been captioned: "Contract labourers on their way back from milking. Ven, August 1934. Photo: Gunnar Lundh (Nordic Museum)". One of the women in the picture has a smile playing on her lips, while the others are clearly more reserved. They return the camera's gaze more or less without expression. The thing is, this is the very same photograph that was used on the cover of Statarna $i$ bild. Or, is it really the same picture? A closer examination reveals that these are actually two different 
shots taken at the same time. However, contrary to what one might expect, the cover of the original reportage book bears a noticeably more upbeat and relaxed image of the homebound group than the later history textbook that intends to present a more nuanced view of contract-labourer life.

Once again we can benefit from the preserved contact sheet. The contact sheet containing the series of photographs in question makes it clear that there are not only two similar images but rather a long series. The preserved photographs show six people whose expressions shift greatly along a scale from serious or sombre to relaxed high spirits. This complicates in an interesting manner the choice of image and the social tendency I previously attempted to link to the common cultural memory of Gunnar Lundh, Ivar Lo-Johansson and the contract labourers. What considerations lie behind the two covers? Why, in both cases, has the choice fallen on a photograph that appears to risk the destabilisation of the authors' own message? Was there a desire to avoid the all too obvious or programmatic? Or has whomever was responsible noticed something in the images that has eluded my own examination? So, the article leads us on once again to a number of unanswered questions. And, once again, we can but confirm the presence of the photo medium's always unfinished nature; the permeability that opens it up to varying interpretations and purposes.

Recent efforts from scholars with an interest in documentary photography have been directed toward the possibility to identify and give biographical accounts for the anonymous persons depicted in the pictures. No doubt, such an ambition might restore some of the agency to the "object", at the same time as it challenges the widespread concept of the photographer as the sole creator of the work. Even though, in this specific case, it might sometimes be better to speak of the established aura of the artist behind the photographer himself, meaning writer and debater Ivar Lo-Johansson.

\section{The Contract-labour Photographs and the Modernisation of Sweden}

Gunnar Lundh's contract-labourer photographs are seemingly difficult to fix in time and space. Not only is there doubt as to which of the pictures from the large collection belong in this category but the photographs have also demonstrated the ability to circulate and appear both in various types of publication and for wildly differing purposes. In many cases, they have even contributed to the design of material staging and built environments. The attempt made in this article to supply the images with some of the context they lack in the museological collection has proceeded via the exploration of elements of their contemporary use and subsequent reuse. Three areas have then been deemed as especially relevant and in need of more in-depth examination: the use of the images in social reportage and 
their links to the emerging welfare state; a biographical trail; and the importance of the photographs to the construal of contract-labourers as a part of Sweden's cultural heritage.

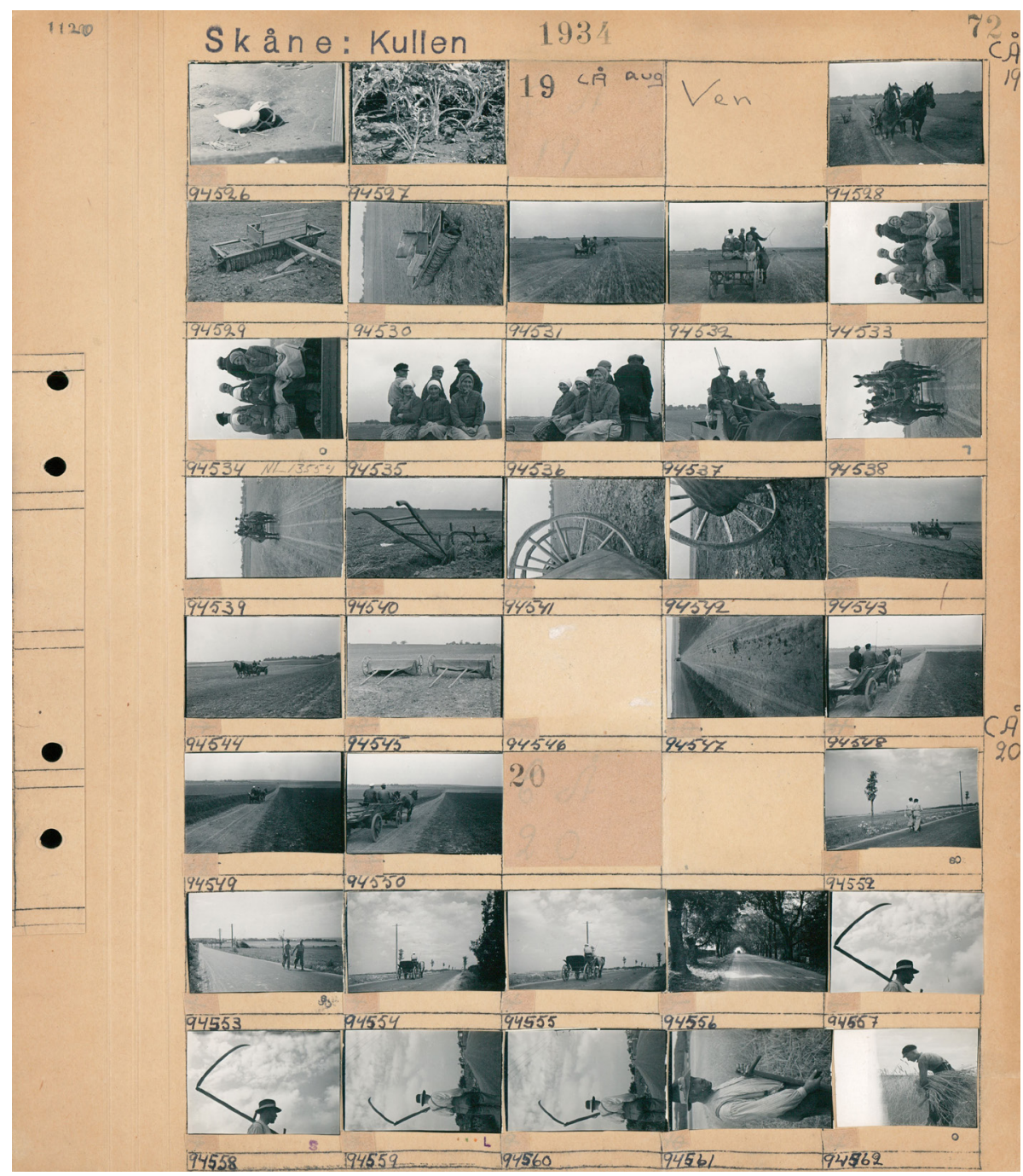

Even if these three points of entry can be viewed as distinct themes, this does not mean that they are entirely separate entities. Rather, a certain exchange is constantly taking place between the three categories. Even more, it is entirely possible to view them as tributaries of the same greater river, namely the ambition to show and document the modernisation of Sweden. Lundh's contract-labourer photographs depict the old Sweden; dirty, hierarchical, poverty-stricken and 
obsolete. This makes it an counterimage of the society we are heading towards, wish to create or believe we have already created. It is an image that offers a distinct point of departure for the narrative of an old, unworthy Sweden; a Sweden that either should be or has been consigned to history.

This forward-looking tendency is already noticeable in the 1937 photo reportage in Vi magazine, and even more so in 1948 with the publication of Statarna $i$ bild. Here, we find a common direction towards the modern, towards folkhemmet and the technological optimism that was a cornerstone of the era's reformative ideas. The contract labourer is replaced by a collective of organised and self-aware agricultural workers. The ox-which can also be read as a symbol of heavy manual labour-is replaced by the modern tractor. The earlier literary hub of the contract-labourer's home, manifested in Lundh's photograph of the shabby "alter of culture", is replaced by reading circles organised for the interested by the Workers' Educational Association and the trade union. Here, in the representation of the modern Swedish welfare state, the three tracks of the circulation of our photographs converge in the overarching presentation of past, present and future. The editors of the above-mentioned anthology, Statarna-i myt och verklighet, appear to draw similar conclusions, ending their introductory chapter by confirming that: "In the modern project, there was no room for the contract-labourers; consequently, the contract-labourer system was abolished in parallel with the Social Democrats' formulation of their post-war programme" (Lundh \& Olsson 2008:36).

Apart from Statarna i bild, Lo-Johansson did publish two other documentary photo books, Old Age (Ålderdom) (with photographers Sven Järlås and Jöran Forsslund) in 1949 and The Way of the Gypsies (Zigenarväg) (with photographer Anna Riwkin) in 1955. This group of books are often referred to as Lo-Johanssons' "social photo books" because they had a stated purpose to bring about debate, as well as to fuel social and political change. Despite the fact that all three publications received a lot of attention when they first met their audiences, it is undoubtedly the contract labour pictures that over time became mostly associated with Ivar Lo-Johansson. One likely reason for this is the circumstance that Lo-Johanssons' own authorship, as a writer of several highly valued novels, to a great extent has revolved around the contract labour theme. Still another explanation, or rather a complementary one, is that the widely-spread knowledge of the contract labour individual, or family, have become a central part of twentieth century Swedish history. Not least, has the sticky concept of the exploited contract labourer been utilised in different kinds of storytellings that wants to stress the importance of the labour movement for the modernisation of Sweden.

Nothing, however, guarantees that the temporal allegation that combine the past, present and future will remain intact forever, or everywhere. It cannot be easy for those who wander through Ivar Los' Park to grasp the political and agitational 
background of which this built environment is also an expression. Perhaps the contract-labourer photographs, too, will fade and lose their currency; perhaps all that remains will be the cows, houses and tractor-an inviting rural idyll shorn of its previous critical and historical context.

Maria Bäckman is associate professor in Ethnology at Stockholm University, department of Ethnology, Religion and Gender (ERG). This article is part of the project Images and Stories of Everyday Life (Vardagens bilder och berättelser), financed by The Royal Swedish Academy of Letters, History and Antiquities, and The Swedish Foundation for Humanities and Social Sciences. Email: Maria. backman@etnologi.su.se

\section{Notes}

1 The images in the article are, when nothing else is specified, taken from the collection of photographs by Gunnar Lundh at the Nordic Museum.

2 It is difficult to state an exact number, among other things due to the fact that Lundh himself rarely categorised his photographs with any clarity.

3 It was only ended by an agreement reached in October 1944 between the Federation of Swedish Forestry and Agricultural Employers and the Swedish Agricultural Workers' Union, which entered into force on November 11945.

4 Statistics on the number of contract labourers are taken from Statarliv-i myt och verklighet (Lundh \& Olsson, ed, 2008:14). The multivolume work Sveriges Historia (History of Sweden) states somewhat different figures. According to Yvonne Hirdman, at its peak at the end of the nineteenth century, the number of contract labourer households reached 34,000. By the time the system was abolished in 1945, the figure had decreased to 7,000 households (Hirdman 2012:57).

5 Ivar Lo-Johansson also collaborated with other photographers with regard to contract labourers; for example, a reportage in photo journal Se together with Karl Werner Gullers under the title: Statarna-Sveriges "Vredens druvor" (Contract Labourers Sweden's Grapes of Wrath) (Se 1940, no. 78, pp 20-24). Lo-Johansson has commented in another context that Gullers has a tendency to beautify his subjects, something that in depicting the living conditions of contract labourers might be perceived as unfortunate, see Lo-Johansson 1985:270.

6 In a discussion on the use of the term circulation within history-of-knowledge research, historians Johan Östling and David Larsson Heidenblad both propose in a similar manner what they call a social circulation of knowledge (2017:279f). In this context, they also emphasise the need for both a broad and inclusive concept of knowledge and concrete studies of how knowledge is used, set in motion and reconfigured (ibid: 279).

7 The Farm Security Administration (FSA) was a US Government agency created as part of President Franklin D. Roosevelt's New Deal, which led to a comprehensive expansion of the state apparatus. The FSA was specifically tasked with improving 
conditions for the country's landless, rural population, with documentary photography playing an important role in the agency's campaigns to shape public opinion. However, art historian Cecilia Strandroth (2007) emphasises that the photography programme was also part of an explicit ambition to market and legitimise the new policy. 8 Similar formulations can also be found in Lo-Johansson's own work, see, for example, the preface to Den sociala fotobildboken, 1977; Till en författare, 1988:44; as well as a longer chapter in Frihet, 1985:265.

9 Among the precursors of social reportage as a literary genre, Swedish examples include Ester Blenda Nordström's En piga bland pigor (A maid amongst maids) (1914) and Ludvig Nordström's Lortsverige (Filthy Sweden) (1938, which was also broadcast as a radio programme earlier that same year). However, none of these publications were illustrated. For a more international overview, see Nilsson (1996: 157f).

10 Folkhemmet is a political concept that entered the lexicon following a speech by Social Democrat leader Per Albin Hansson in a parliamentary debate in January 1928, in which it was used to describe the society that social democracy hoped to achieve. Source: NE.

11 Lo-Johansson also wrote a long chapter on the contract labourers in Skansen's information leaflet, Statarlängan från Berga (The Berga farm labourers' cottage), 1975. 12 There are two photographs hanging above the bed depicting an elderly man and woman. Visitors often assume that this is the Carlssons but it isn't. The man is in fact Ivar Lo-Johansson, who has thus managed to find his way into this constructed museum environment.

13 That this need not always be the case is demonstrated not only in the Carlsson's transported home in Skansen, but also by a constructed interior of a labourer household at the Utö Mining Museum, located in Stockholm's northern archipelago. This exhibit expressly takes its cue from the image of contract labourers created in proletarian literature.

14 Lo-Johansson rented two small one-room apartments at Bastugatan 21, living in one and working in the other.

15 Ivar Lo-Johansson's entry in the Dictionary of Swedish National Biography asserts that he was the first person Sträng called after the decision to abolish the contract-labour system was reached. The same story reappears in the 1995 SVT documentary Den vita piskan (The White Whip), which is available in the SVT open archive (see also Furuland 1976:192f.)

\section{References}

Magazines and newspapers

Vi, no. 471937.

Se, no. 781940.

Folket $i$ Bild, no. 31975.

Svenska Dagbladet 23.09.1948. 


\section{Culture Unbound}

Journal of Current Cultural Research

\section{Internet Sources}

Gunnar Lundh: Dictionary of Swedish National Biography https://sok.riksarkivet.se/ sbl/Presentation. aspx?id=9848 (visited 07.12.2018)

Gunnar Sträng: Dictionary of Swedish National Biography

https://sok.riksarkivet.se/Sbl/Presentation.aspx?id=34558 (visited 07.12.2018)

https://sv.wikipedia.org/wiki/Semester (visited 24.08.2019)

\section{Literature}

Andén-Papadopoulos, Kari (2008): "Medievetenskapens döda vinkel. Från pantextualism till visuell mediekultur". Solveig Jülich, Patrik Lundell \& Pelle Snickars (eds.): Mediernas kulturhistoria. Stockholm: Statens ljud och bildarkiv, 293-317.

Appadurai, Arjun (ed.) (1988): The Social Life of Things. Commodities in Cultural Perspective. Cambridge: Cambridge University Press.

Aronsson, Peter (2004): Historiebruk. Att använda detförflutna. Lund: Studentlitteratur.

Barthes, Roland (2007 [1970]): Mytologier. Lund: Arkiv.

Berg, Gösta (1975): "Förord till första upplagan”. Ivar Lo-Johansson, Mats Janson \& Ingemar Liman (eds.): Statarlängan från Berga. Skrifter från Skansen 5, Stockholm, 4-5.

Czarniawska, Barbara (2007): Shadowing and Other Techniques for Doing Fieldwork in Modern Societies. Malmö: Liber

Cronqvist, Marie, Patrik Lundell \& Pelle Snickars (2014). "Inledning". Marie Cronqvist, Patrik Lundell \& Pelle Snickars (eds.): Åter-kopplingar. Lund: Mediehistoria, Lunds universitet, 9-30.

Dahlman, Eva (1993): "Kort om kort-om museernas insamling och urval av fotografier". Adomus-nytt, no. 151993.

Ekström, Anders (2004): "Vetenskaperna, medierna och publikerna". Anders Ekström (ed.): Den mediala vetenskapen. Nora: Nya Doxa, 9-31.

Ekström, Anders (2008): "Kulturhistorisk medieforskning: Fyra spår". Solveig Jülich, Patrik Lundell \& Pelle Snickars (eds.): Mediernas kulturhistoria. Stockholm: Statens ljud och bildarkiv, 31-45.

Furuland, Lars (1975): Statare. Statarklassens historia i ord och bild till 30-årsminnet av sista statarlasset. Stockholm: Nordiska museet.

Furuland, Lars (1976): Statarnas ombudsman i dikten. En bok om Ivar Lo-Johanssons av Lars Furuland. Stockholm: LT/Svenska lantarbetarförbundet.

Gullers, Peter (2003): "Om det dokumentära. Fotografi som fakta och föreställning". Nätverket, 2003:12, 4-16.

Gustavsson, Lotten Reinius (2013): Kongobussen kommer! Den etnografiska vandringsutställningen som ett etnografiskt medium. Lotten Gustafsson Reinius, Ylva Habel \& Solveig Jülich (eds.): Bussen är budskapet. Perspektiv på mobilitet, materialitet och modernitet. Stockholm: Kungliga biblioteket, 29-53.

Hariman, Robert \& Lucaites, John Louis (2007): No Caption Needed. Iconic Photographs, Public Culture, and Liberal Democracy. Chicago: University of Chicago Press.

Hassner, Rune (1970): Jacob A. Riis. Reporter med kamera i New Yorks slum. Stockholm: Norstedt.

Hassner, Rune (1977): Bilder för miljoner. Bildtryck och massframställda bilder från de första blockböckerna, oljetrycken och fotografierna till den moderna pressens nyhetsbilder och fotoreportage. Stockholm: Sveriges radio.

Hellspong, Mats (2004): "Statareländet. Ivar Lo-Johansson och bilden av statarna". Mats Hellspong, Karin Lindvall, Nicole Pergament \& Angela Rundquist (eds.). Herrgårdsromantik och statarelände. En studie av ideologi, kulturarv och historieanvändning. Stockholm: Carlsson, 267-316. 


\section{Culture Unbound}

Journal of Current Cultural Research

Hirdman, Yvonne 2012. "Porträtt av ett land". Yvonne Hirdman, Jenny Björkman \& Urban Lundberg (eds.): Sveriges Historia 1920-1965. Stockholm: Nordstedt, 54-82.

Jülich, Solvieg, Patrik Lundell \& Pelle Snickars (2008): “Mediernas kulturhistoria: en inledning". Solvieg Jülich, Patrik Lundell \& Pelle Snickars (eds.): Mediernas Kulturhistoria. Stockholm: Statens ljud och bildarkiv, 9-29.

Jülich, Solveig (2015): "Lennart Nilsson's A Child is born. The Many Lives of a Pregnancy Advice Book". Culture Unbound, 2015:4, 627-648.

Koivunen, Leila (2009): Visualizing Africa in Nineteenth-Century British Travel Accounts. New York: Routledge.

Latour, Bruno (1998): Artefaktens återkomst. Ett möte mellan organisationsteori och tingens sociologi. Stockholm: Nerenius \& Santérus.

Liljestrand, Jens (2018): Mannen i skogen. En biografi över Vilhelm Moberg. Stockholm: Albert Bonniers Förlag.

Lindvall, Karin (2004): "Introduktion. En tidlös symbol? Det svenska samhället och herrgårdens skiftande skepnader". Mats Hellspong, Karin Lindvall, Nicole Pergament \& Angela Rundquist (eds.): Herrgårdsromantik och statarelände. En studie av ideologi, kulturarv och historieanvändning. Stockholm: Carlsson, 11-22.

Lo-Johansson, Ivar (1975): “Om statarna”. Ivar Lo-Johansson, Mats Janson \& Ingemar Liman (eds.): Statarlängan från Berga. Skrifter från Skansen 5, Stockholm, 7-94.

Lo-Johansson, Ivar (1977): Den sociala fotobildboken. Stockholm: Rabén \& Sjögren.

Lo-Johansson, Ivar (1985): Frihet. Stockholm: Bonniers.

Lo-Johansson, Ivar (1988): Till en författare. Stockholm: Bonniers.

Lundh, Christer \& Mats Olsson (eds.) (2008): Statarna-i myt och verklighet. Hedemora/Möklinta: Gidlunds

Mintz, Sidney Wilfred (2013): Sweetness and Power. The Place of Sugar in Modern History. Johanneshov: MTM

Nilsson, Bo (1975): "Fotografen Gunnar Lundhs bildsamling". Göran Bergengren, Heidi Henriksson \& Mátyás Szabó (eds.): Sista lasset in. Studier tillägnade Albert Äskeröd 9 maj 1974. Stockholm: Nordiska museet, 93-106.

Nilsson, Bo G. (1996): Folkhemmets arbetarminnen. En undersökning av de historiska och diskursiva villkoren för svenska arbetares levnadsskildringar. Stockholm: Nordiska museet. Diss.

Nordström, Ester Blenda (1914): En piga bland pigor. Stockholm: Wahlström \& Widstrand. Nordström, Ludvig (1938): Lortsverige. Stockholm: KF Bokförlag.

Nyblom, Andreas (2014): "Ritualer vid skriftkulturens altare. Skrivbordets och arbetsrummets mediehistoria". Marie Cronqvist, Patrik Lundell \& Pelle Snickars (eds.): Ater-kopplingar. Lund: Mediehistoria, Lunds universitet, 109-134.

Oldberg, Ragnar (1964): Ivar Lo-Johansson. En bildbiografi av Ragnar Oldberg. Stockholm: Bonniers.

Reberg, Arne (2001): Ivar Lo. De utsattas reporter. Stockholm: Bilda.

Ristilammi, Per-Markku (1994): Rosengård och den svarta poesin. En studie av modern annorlundahet. Stockholm: B. Östlings bokförlag, Symposion. Diss.

Rittsel, Pär \& Rolf Söderberg (1983): Den svenska fotografins historia 1840-1940. Stockholm: Bonnier fakta.

Statarna i bild (1948): Ivar Lo-Johansson \& Gunnar Lundh. Stockholm: KF Bokförlag.

Strandroth, Cecilia (2007): In Search of the Pure Photograph. A Historiographic Study of the Farm Security Administration, Walker Evans and the Survey Histories of Photography. Uppsala: Uppsala University. Diss.

Strandroth, Cecilia (2009): "På forskningsresa i det digitala bildarkivet - ett brukarperspektiv". Anna Dahlgren \& Pelle Snickars (eds.): I bildarkivet. Om fotografi och digitaliseringens effekter. Stockholm: Kungliga Biblioteket, 91-120.

Thorbech, Åsa (1994): "Vardagsnära bilder. Om fotografen Gunnar Lundh". Tack vare våra vänner! Fataburen 1994. Nordiska museets och Skansens årsbok 1994. Stockholm: Nordiska museet, 124-141.

Östling, Johan \& David Larsson Heidenblad 2017: “Cirkulation-ett kunskapshistoriskt nyckelbegrepp”. Historisk tidskrift, 2017:2, 269-284. 


\title{
Framing Childhood: Representations of Children in Gunnar Lundh's Photo Agency Archive
}

\author{
By \\ Helena Hörnfeldt
}

\begin{abstract}
Based on Gunnar Lundh's photographs from the period 1920-1960, this article aims to discuss how a visualisation of children and childhood in cultural history collections can be addressed. This period is known as the time when the Swedish welfare state and society took shape, a period when the conditions for children in society changed in a number of ways. Lundh's photographs are therefore viewed as cultural expressions of an era of cultural, societal and political change in which photographs of children came to play a particularly important role. Some of Lundh's pictures have been reproduced in works about the constructive period of the Swedish welfare state and have thereby had an important role in narrating the story of the welfare society. In this way, Lundh's photographs of children must be understood in the specific context of visual representations of children and childhood from this time period. In the many pictures of children in Lundh's collection, the children play, are dressed up in fine clothes and national costumes, visit the library, pick flowers, play along the shore, etc. The children are depicted both active and passive, innocent, childish and pure. In that sense, the photographs follow a genre-specific way to portray children which was typical at the time and still is. In the article, I argue that an understanding and a specific way of seeing and portraying children and childhood became institutionalised during this period. However, in this institutionalisation process of images of childhood, Lundh's pictures of children seem to reproduce and enhance this "pictorial vocabulary" in many ways that appear natural to childhood.
\end{abstract}

Keywords: Children, Childhoods, Photographic genres, Pictorial vocabulary, Representation, Sweden, Welfare state.

Hörnfeldt, Helena "Framing Childhood: Representations of Children in Gunnar Lundh's Photo Agency Archive.", Culture Unbound, Volume 12, issue 1, 2020: 6589. Published by Linköping University Electronic Press: http://www.cultureunbound. ep.liu.se 


\section{Introduction}

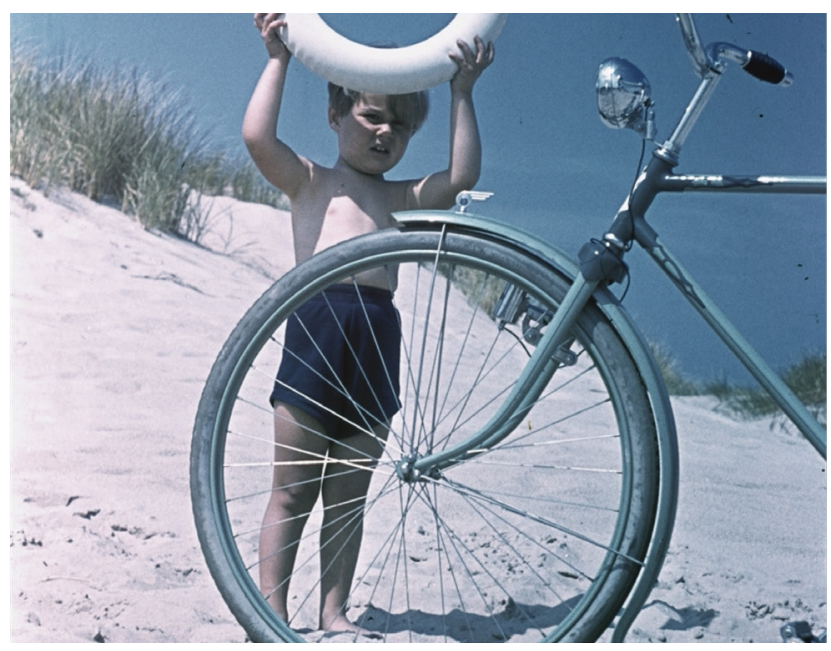

Fig. 1. Child with a swim ring next to a bicycle. Sandy beach, 1940 (NMA.0049367).

A child is standing behind the front wheel of a bicycle, holding a swim ring above their head. ${ }^{1}$ The photo is shot on a beach with white sand dunes in the background. The child looks straight into the camera. By its composition with the bicycle's front wheel in the foreground of the child who appears to be put on display, the picture gives an impression of being artistically designed. The photograph was taken in 1940 by the photographer Gunnar Lundh and is one of several depicting either children and bicycles or children on beaches. The composition in the picture, in which a person is placed behind the front wheel of a bicycle, is a recurring motif in Lundh's collection. So are pictures of carefree, playful and healthy children in outdoor surroundings.

The first pictures of children in Gunnar Lundh's photo collection are from the 1920s. However, most of them are shot during Lund's most productive period between the 1930s to 1950s. ${ }^{2}$ This period is known as the time when the Swedish welfare state and society took shape, a period when the conditions for children in society changed in a number of ways. During the first decades of the 20th century, children gradually became regarded as a specific category with distinctive features and specific needs and rights, such as schooling, leisure and health (cf. Sandin 2003). Parallel to the child-saving movements that gained significant influence in many Western nations in the beginning of the twentieth century, the emotional value of children was augmented (Sandin 2012:62). 
Society's responsibility for, interest in and insight into the lives of children increased significantly during Lundh's productive period. Using new, modern institutions for children and families, such as preschools, child health care centres and social security systems, society was given the opportunity to both control and educate parents and children, and form a modern individuality that could meet the demands of a more complex society (Hörnfeldt 2009:124). The vision was that Swedish society had to reform and disengage from ancient traditions and bad customs (cf. Hirdman 2000:126). The idea of society as a community where solidarity, reason and justice would prevail for everybody is also what came to be summarised in Per Albin Hansson's metaphorical concept of "The People's Home" (Folkhemmet in Swedish). ${ }^{3}$ In this community, all citizens would be entitled to a better home, better food, better education, better care, etc. (cf. Hirdman 2000:90). Pictures of children standing or sitting in front of newly built, modern blocks of apartments, or health care professionals, or mildly monitoring school professionals therefore served as examples to spread what many scholars have referred to as welfare propaganda (see, for example, Jönsson 2011). In that sense, photographs of children served as ideological support for welfare policy on public health and eugenics (Habel 2002). These kinds of commonly occurring visual representations of children were also one of many ways to show the importance of children in correlation with the future of the nation (Hallberg 2017:266 cf. Peacock 2014).

\begin{abstract}
Aim
The article sets out from the standpoint that photographs are cultural expressions. Based on Gunnar Lundh's photographs from the period 1920-1960, this article aims to discuss how a visualisation of children and childhood in cultural history collections can be addressed. These photographs are therefore viewed as cultural expressions of an era of cultural, societal and political change in which photographs of children came to play a particularly important role. To problematise the visual representation of children and the life depicted on the basis of photo-historical material is an overall aim of the article. What stories about children's lives and society's relation to childhood do Gunnar Lundh's pictures tell? In what ways are dominant values, norms and political visions of the nascent welfare state present in Lundh's pictures? How are the children portrayed in the photographs? Are differences in terms of gender, age and ethnicity visible in the pictures? Additionally, the article will explore methodological issues, such as: How are the photographs in the collection related to each other? Is it possible to say something substantial based on only one picture without knowing anything about its origin or the motif? What other sources are needed to understand the photographs and children's terms and conditions of living as exposed in these photographs?
\end{abstract}


Since most of the photographs in Lundh's collection are archived without specific information about motives and approaches, it becomes crucial to understand the context surrounding the photographs. In what setting are they shot? What are the children doing, how are they depicted and what kind of knowledge is possible to obtain through these photographs (cf. Becker, Ekecrantz \& Olsson 2000, Blomberg 2005, Leipe 2001)? Is it, for example, possible to learn something from the photographs about children's lives during the time-period studied? This also raises the question of how these photographs of children talk to other visual representations of children published or circulated during the same timespan. In what sense are Lundh's pictures expressions of genre-specific motives situated in time and place? Another circumstance that can be scrutinised is the relationship between the person taking the picture and the one being photographed. Generally, children relinquish control to the photographer which makes them ideal subjects for the camera (Holland 2004:9). As children are normally in a subordinate position in relation to an adult photographer the question of which subjects that are able to resist being depicted becomes essential.

In addition to what has been said above, it is also interesting to ask why there are, relatively speaking, so many photographs of children in the archive. For what purpose have the photos been taken and filed? One should bear in mind that the photographs in Lundh's photograph agency were intended to finance his and his family's life. These social facts make the issue of whether photographs of children were particularly lucrative during the period interesting and perhaps necessary.

Children's lives and situations are best understood in relation to adults' perceptions and hopes of a certain kind of childhood. Thus, one key question is if it is possible to understand photographs of children at all, without analysing them from an adult-child relational perspective (cf. Alanen 2009)? The pictures might not tell us anything essential about children's lives from the children's own perspectives. Rather, it might be a story of how a normative adult world wanted children to be represented.

\section{Pictures and Processes}

The main material for this article consists of photographs of children from Gunnar Lundh's photo agency archive. Among the 300000 pictures in Gunnar Lundh's commercial photographic archive, there are many photographs of children at different ages. The children in the pictures play, are dressed up, stand in front of and sit in fancy cars, visit the library, wash dishes, pick flowers, play along the shore, etc. Sometimes they are depicted alone, and sometimes with other children or with one or more adults. In connection with certain photos there is 
information added, such as where and when the picture is taken and who the child is. Occasionally, the subjects in the photos are the children of Lundh's close friends whom he visited during his travels around Sweden. Sometimes the people in the photos are his own relatives, as, for example, the pictures of his daughter Jytte (cf. Steinrud in this publication). Lund's private and professional lives thus appear to be almost equally important parts of his archive.

Analysing the photographs, I started by putting them in chronological order. I then selected some recurring themes, such as the innocent child, the playful child, the child in nature and the child as an aesthetic project. These themes also constitute the structure of this article. In the process, I let my previous research on children and childhood during the period of the welfare state's construction in Sweden lead the way (Hörnfeldt 2009, 2015). Therefore, previous studies of this period with a particular focus on visualisation of children in photographs and images have given a comprehensive understanding of how pictures of children were used to communicate political messages (see for example Habel 2011, Hallberg 2017, Higonnet 2013, Jönsson 2011). Some of Lundh's pictures have been reproduced in works about the constructive period of the Swedish welfare state and have thereby had an important role in narrating the story of the welfare society. In this way, Lundh's photographs of children must be understood in the specific context of visual representations of children and childhood from this time period. However, placing this study in the range of previous research on the welfare state is not without problems. The period when the welfare state was constructed has been both accurately and thoroughly researched, although most studies have primarily concerned the discursive level. This has led to a rather undiversified understanding of this specific time period in Swedish history. My own research is no exception in that respect (Hörnfeldt 2009, 2015). Hence, a uniform story about the welfare state has led to a grand narrative of this time-period, which has in turn become more true than the lives actually lived. However, few studies have focused on depicting people's lives (or in this case children's lives) in relation to the great societal transformations that took place. Since this study also mainly concerns a discursive level that Gunnar Lundh's photographs of children convey and construct, there is an imminent risk that the results show what previous research has already shown. With that said, I would like to point out that the interpretations of the photographs and Lundh's archive as a whole have been characterised by an awareness of these matters.

One way to contextualise the photos is, as mentioned above, by reading previous research about historical photographic material on children. In a Swedish context, there is a limited selection of scientific works on photographs of children taken during Lundh's productive period, which occurred during the 1930s to 1950s. In many of the works that deal with this specific epoch in 
Swedish history, pictures of children have rather been used to show how some popular adult education elements formed the welfare state's relationship with the individual. However, one work that served as an inspiration for my interpretations of Lundh's photographs and the discussion about its source-historical value is Mathilda Hallberg's dissertation from 2017, Children on display. Family, Welfare state and Nation in Photo Contests and Photo Books 1930-1944. Hallberg's thesis deals with the same time period as Gunnar Lundh's collection of photographs.

\section{Photographs of Children as Historical Sources}

Within ethnological research, photographs and other images have seldom been used as main sources to understand cultural processes and are therefore not commonly used, except as illustrations. As in historical research, ethnological research has been primarily text-based (cf. Blomberg 2006). On the other hand, many ethnologists have used cameras in their fieldwork, though as an extra eye, perhaps with the primary aim of not forgetting people, artefacts and settings. Nevertheless, the use of images as a basis for analysis is unusual, even though there are some ethnological exceptions. For example, Nils-Arvid Bringéus' book about "Imagelore" (Bildlore) from 1981 (Bringéus 1981), Anja Petersen’s work with photographic portraits (Petersen 2007), Marianne Larsson's dissertation about postal uniforms (2008) and finally Simon Ekström's work about the cultural history of lobsters (Ekström 2017) are some examples of ethnological work that fits into the field of visual cultural history. This field is definitely growing, in addition to other image interpretation disciplines (Petersen 2007:24f), as is the case with ethnology. The historian Eva Blomberg describe this turn as a pictorial turn (Blomberg 2006:37f).

In order to use photographs as historical sources, there is a need to see the pictures and find a way to systematise what we see (cf. Blomberg 2005:266). Photographs have a special quality in that they often evoke emotions in a particular way. Perhaps this especially applies when there are children depicted or when the photographs stir up memories and offer feelings of nostalgia. In general, an image of a child "both creates conceptual meanings and carries a powerful emotional charge" (Holland 2004:2). Photographs, for their part, offer a sense of both reality and illusion since they are simultaneously more representational and fantastic than language and written texts (cf. Holland 2004:6). Photography has an aura of truth and documentation, even though everyone that has been portrayed in a photo knows that there are many things going on behind the scenes that are not obvious in the final result (cf. Olsson 2000). The meaning of photographs is always intimately linked to the layout, captions, context and use (Sekula 2003:445). A photographic image cannot, therefore, be perceived as a mirror of reality but as a construction. 
Photographs have often been regarded as illustrations of the written. However, if the object of study is the photograph itself, there are other considerations that must be taken into account. There are many ways of understanding pictures and also several methods involved in a visual analysis. In my analysis of Lundh's pictures of children, I primarily relate to how photographs make sense and how they are identifiable. Moreover, I am interested in how pictures construct knowledge and knowing (cf. Blomberg 2005:267). Gunnar Lundh's photo collection should likewise be understood as a whole. Analysing only one photograph from a vast image archive means taking it out of its context. Bengt Erik Eriksson and Roger Qvarsell have argued that a compilation of photographs in a photographic archive should be understood as constructed visual narratives aimed at portraying processes of social change (Eriksson \& Qvarsell 2003).

Accordingly, to study historical photographs of children requires an interpretation of the exposed subject based on how it appears in relation to the context. Describing how children are portrayed in the photos therefore becomes the central task.

\section{Children as a Historical Category}

To write about children in the past is difficult since the children's own voices are rarely documented. Children as physical beings, and childhood as a concept, have existed as a phenomenon in society throughout history, even though the meaning of childhood has changed. In the archives, however, children's voices are partially silent and invisible. Before I elaborate more on the epistemological and methodological issues concerning the study of children and childhood in the past, a discussion about the category of children in general is needed. How is it possible to know when the historical photograph is depicting a child? Or, phrased differently: How is a child recognisable in photographs?

Firstly, the category of children holds everything from an infant to an almost full-grown 18-year-old. The fact that the variation is great may not, however, be that strange. Age is not always synonymous with chronological age; we also have a biological age, phenotypic (appearance) age, and intellectually can we discuss mental age. In addition to these parameters, it is not uncommon to achieve a social age by demonstrating certain skills. As a result, many childhood researchers have claimed that children as a category is culturally constructed and any definition of what a child is therefore contradicts itself (see, for example, Fahlander 2011:29). There are, nevertheless, certain general factors and characteristics that usually differentiate children from adults, such as size, appearance, clothing, dependence, practical and social experience, etc., even though these factors are always situated 
in time and place (cf. Cunningham 2006:13). However, in order to recognise childhood, children are surrounded by attributes such as special children's clothing, toys and things that recreate leisure and play. These attributes, for the most part, also signal non-productivity and innocence (Hörnfeldt 2009:99).

Children are placed in a 'non-adult' category and therefore not thought of as citizens, gendered and sexual beings-in some cases they even stand somewhere between animals and humans. It makes the category very interesting to discuss in order to better understand general questions about social structure and ideology in a given time and place (Fahlander 2011:7). Still, there are obvious differences, for example, between how girls and boys are portrayed in Lundh's photographs. For this reason, it is crucial to ask the question how the children are depicted in relation to age, ethnicity, sex and class.

What is mostly preserved in the folk life archives is adults' memories of their childhood and other sources that reveal society's understanding of what a child is (cf. Hyltén Cavallius \& Fernstål, in this publication). Gayatri Spivak's (1998) concept of the 'subaltern' is sometimes used to describe children, since it is seldomly children's own thoughts and understandings that are heard (cf. Fahlander 2011:5). As a subaltern is a subject whose voice does not have any space in the general discourse, adults are the ones who define what a child is and what a childhood should be, regardless of whether it is a matter of past or present (cf. Cunningham 2006). To give children their own voice has therefore become both a starting point and a goal in modern childhood research.

Another issue when studying children and childhood in the past concerns how the subject of childhood has often been ignored and trivialised. It is not until recent decades that childhood studies have raised the issue of how childhood has been overlooked or dismissed in history studies. Just as class, gender and race have challenged academic disciplines, the subject of generation is now raising the same challenges (cf. Alanen 2009, Higonnet 2002:200). Nevertheless, the Swedish research on children's history is, as the historian Susanna Hedenborg writes, confusingly small (Hedenborg 2018 (2005:9). Hedenborg reflects on this gap and poses the question of whether this has to do with children's lack of power in society or if the answer has to do with research about children rarely being connected with high scientific status. Since children are seldom described in historical sources, one reason for the silence of interpretations of childhood in the past could be that the primary sources are too few to provide a basis for new knowledge about children.

Although the children's own voices from the time period 1920-1960 seem difficult to reach, photographs taken of children during this period were popular. Gunnar Lundh was undoubtedly not alone in focusing on children in his photos. Hallberg writes that the culture of visual display and the growth of the welfare 
state and the "modern project" are closely linked together. Films and pictures of children have, for example, been emphasised as tools with which to communicate ideological support for political messages (Hallberg 2017:15, 266, cf. Habel 2002). The representations of children became tools in the formation of society. The practice of using children as photographic motifs in the social debate was however not solely a Swedish phenomenon. Visual representations of children were, for example, an important part of the construction of national ideals in both Soviet and Nazi propaganda (Peacock 2014, cf. Hallberg 2017:15).

As previously mentioned, the time when Gunnar Lundh was active as a photographer was a time when children's lives and conditions changed fundamentally. At the end of the 1920s, there was at the same time both a strong optimism about the future and concern about the children of society. The reason for concern in the late 19th century were the ideas that children should be saved from the effects of inhumane industrialisation, where they grew up in unsightly homes, lacked nutrition and care and drifted around in the city's damaging environment (Cunningham 1991, Sandin 2003:225). The decades after the turn of the century were characterised by a kind of conceptual struggle over the interpretations and meanings of children and childhood. This struggle also meant that children became visible as political objects in a different way than before. It is in this context that the photographs of children in Gunnar Lundh's photographic collection must be understood.

\section{The Innocent Child}

When writing about children in the past one must consider how children are often assumed to have been an exposed, exploited and affected category. This politically useful mantra has been fundamental in how children have been depicted, read and interpreted in historical sources and visual representations. There are certainly many reasons for such a reproduction, perhaps due to popular cultural expressions, such as Dickens' Oliver Twist (1837-39) (Pollock 2002:XVI.). In photos from the eighteenth century and early twentieth century, children are often portrayed as small adults, standing together with their family as parts of an economic and productive unit (see, for example, Reinius 1986, cf. Hallberg 2017). Not infrequently do they look sad and solemn. The children in such photographs are not depicted as essentially different from the adults except that they, due to their height, are strategically placed at the front of the photo. The children do not wear distinguishably different clothing from the adults apart from the fact they are smaller in size.

There is also the tradition of portraying children as innocent, cute and authentic. According to Heywood, the linkage between childhood and innocence 
became ingrained in Western culture, a lasting legacy of the Romantics of the nineteenth century (Heywood 2005/2018:57-58). Yet it was in the medium of photography that these images of a romanticised childhood found their fullest expression (Higonnet 2013:297-298). Art historian Anne Higonnet writes that "romantic childhood needed a medium whose claims to natural innocence and spontaneity were credible as its own. That medium was photography." (Higonnet 2013:301).

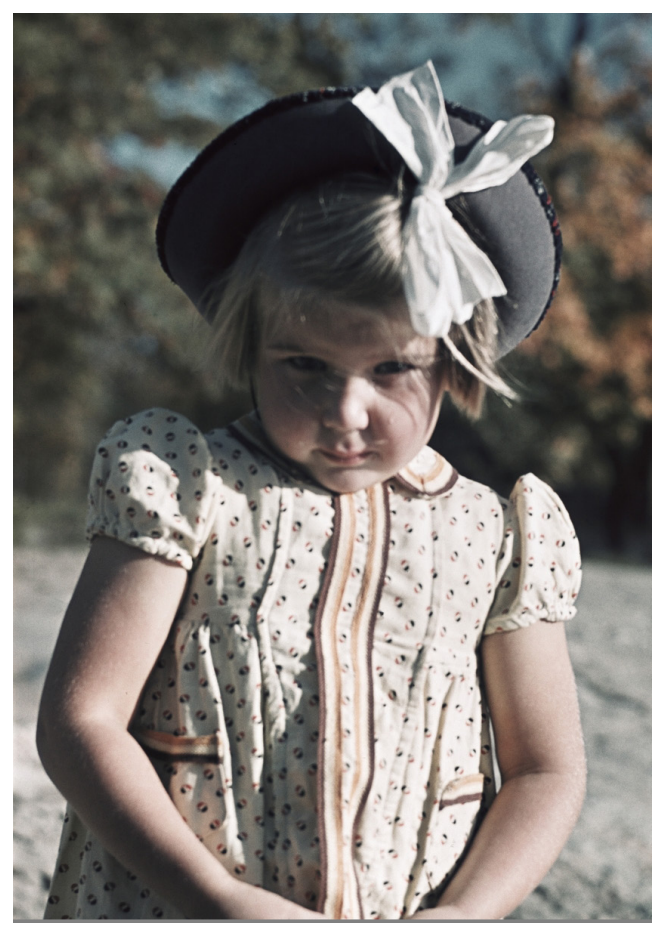

Fig 2. Small child wearing a spotted dress and a hat with a bow, 1941 (NMA.0054487).

However, the idea of the innocent child has several meanings. In the picture above, I see a relatively small child, dressed up in a dress with puff sleeves, a hat and a white ribbon. Moreover, the child is looking with downcast eyes into the camera lens, which gives a vulnerable, almost scared appearance. The shy and grave expression also captures the consciousness of being looked at and the unequal relationship with the adult photographer. If we turn from the child and look at the surroundings, there are some blurry trees with perhaps late season leaves in the background. It also seems like the child is standing on a cliff, possibly close to water. Judging by the balanced relationship between the child's position and the surroundings, the photo looks, like the picture above of the child on the beach, 
arranged and carefully composed compared to many of Lundh's other pictures, which are taken in the moment without any apparent intent of composition.

In addition to the picture itself there is not much information that comes with the photograph, except for the notice of when the picture is taken, namely 1941. The picture has been digitised and is published on the site "Digitalt museum" (Digitised museum) with a short description of the motif. "Little girl wearing a spotted dress and a hat with a bow" (my translation). So, to contextualise the picture it is necessary to search deeper into the archive. What other pictures, for example, are printed on the same contact sheet? Is it possible to acquire more information about the picture when looking at the contact sheets in close relation to this specific one? Are they sorted chronologically? After finding the contact sheet with the photo of the child above, I studied the adjoining contact sheets more carefully. First of all, it appeared that the photograph is a diapositive and that the contact sheets are chronologically organised. On this specific sheet there is one more photo of the same child, standing in the same spot but looking upwards rather than straight into the camera. There is no written information about where the photo is taken, who the child is or why Lundh has chosen to take the picture. The other photographs on the same contact sheet portray two different adult women, one standing with a book in front of a bookshelf and the other in different outdoor settings: in front of a pond, on the staircase to an older house and leaning against a birch tree. The women are both well-dressed; the second woman is wearing high heels, a checked dress, hat and overcoat. At the bottom of the same contact sheet there is a series of photographs of two and three women in folk costumes standing in front of a traditional Swedish fence, behind which there are some cows. Since the large number of photographs of the woman in the checked dress depict her in different poses in front of various trees on which the leaves change in colours, one could assume that these pictures are taken during early autumn. In addition, based on the clothes that both the women and the child are wearing, it is obvious that there are no real farmers or occupied farmhouses depicted in the pictures. Rather, as I started to recognise places and buildings represented on the contact sheets, I became convinced that these photographs are taken at the open-air museum Skansen in the centre of Stockholm. In addition, after my review of most of Lundh's many contact sheets, it is apparent that Skansen is one of his more frequently used photo sites, even generating a category of its own in his archive. The contact sheet in which the photographs of the child with the spotted dress are printed on is thus one of many with similar motifs in Lundh's photographic archive. Skansen is a place many Swedes have visited during holidays and leisure time for the purpose of walking, enjoying the old Sweden and watching Nordic animals. Skansen is thus also a typical place for photography in general. In addition, Skansen is a place that has a strong national symbolic 
value where Swedish history, traditions and nature are embodied in one place. Therefore, it has an aura of a lost Sweden in which people lived close to nature and animals. A lifestyle that was at the time and still is associated with the idea of an ideal childhood. Hallberg writes that Skansen is presented in the photobook "Svenska barn i bild" (Images of Swedish Children) ${ }^{4}$ as a special, culturally significant place for children where they are offered an experience of a traditional agrarian lifestyle and a childhood with proximity to animals and nature (Hallberg 2017:234). Thus, an experience that contrasts with the dirty and unhealthy urban life of industrialisation and modernisation. Within this context, the dressed-up child in the photo becomes more contextualised and comprehensible.

As shown in my interpretative description of the photograph above, the child looks shy and almost grave. There are several signs in the photograph, such as the dress, the white ribbon and the appearance of the child that leads the mind towards the thought of a girl. Equally important, it is hard not to notice and sense the cuteness in the picture. Perhaps the most common perception of children's 'being' is characterised by innocence, spontaneity, naturalness and honesty, which is put in contrast to the cultured adult individual (Holland 2004). Compared to the photographs of the adult women on the same contact sheet, the assumed girl appears to be significantly less aware, in that she does not pose or make herself look beautiful in front of the camera. Rather, she is portrayed as physically charming, but not intentionally (cf. Higonnet 1998:71). In that sense, the photographic gaze differs between children and adults. Among Lundh's photographs of children, there is a considerable amount that portrays the children in this way: shy, sweet and lovable. Higonnet writes that pictures of childhood, categorically different from adulthood, first appeared in significant numbers in mid-eighteenth-century British portraits. British painters introduced the vision of a disembodied childhood, a cute childhood, a miniaturised childhood (Higonnet 2013:298). Curator of nineteenth-century photographs (department of photographs at the National Gallery of Art, Washington) Diane Waggoner also claims that photographs of Alice Liddell and other children in the 1850s to 1860s by Charles Lutwidge Dodgson (known as Lewis Carroll) marks a crucial historical moment in the history of modern childhood. "Just as Alice's Adventures in Wonderland transformed the genre of children's literature, Dodgson's photographs established new visual parameters for the representation of children that articulate a historical concept of the self-predicated upon an explicit differentiation of children from adults" (Waggoner 2002:149). Among Lundh's photographs of children, there are some that definitely portray children in this intertextual manner: the innocent and authentic, natural and pure, only aware of the present moment (cf. Holland 2004:9). 


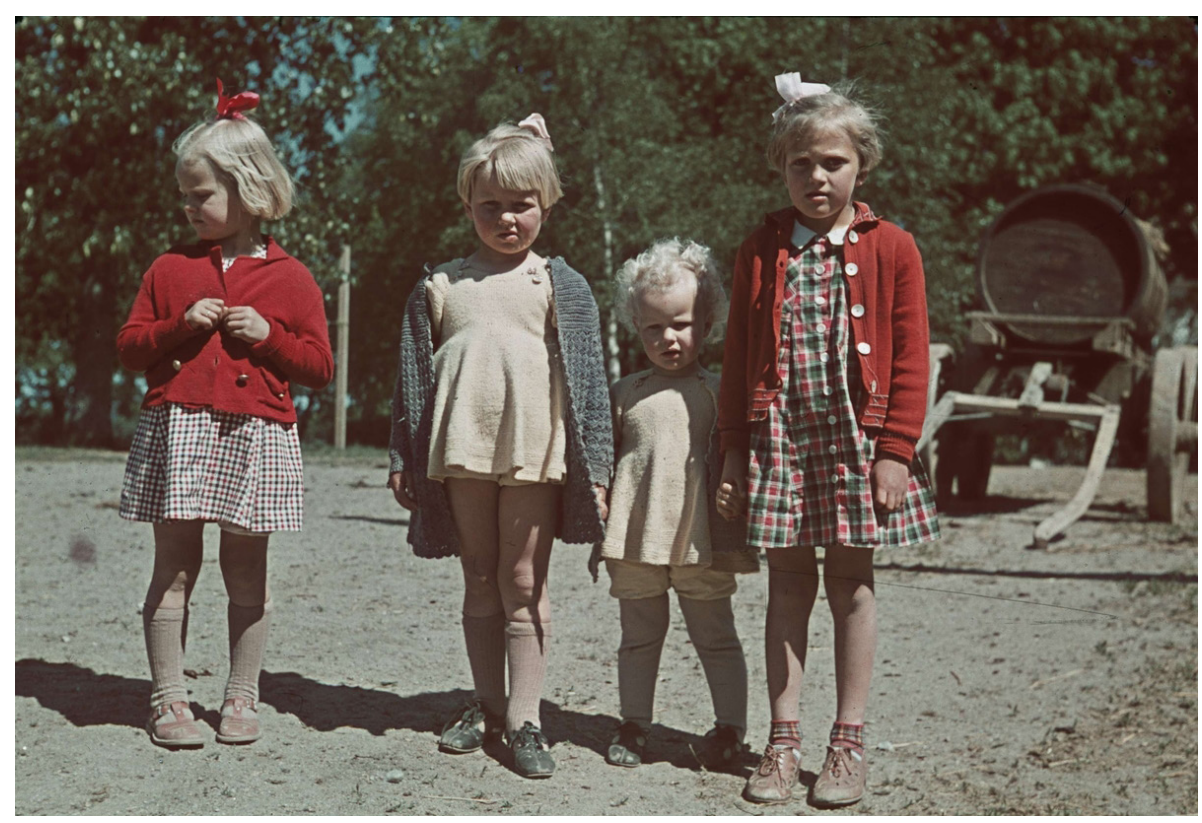

Fig 3. Four children dressed in summer dresses, 1941 (NMA.0050196).

As mentioned above, the constructed idea of the innocent child has several meanings. Since many of Lundh's photographs of children were taken during or in close association with World War II, it is not far-fetched to understand the great interest in photographs of children as a way to offer the people and the nation a great hope for the future. The children represented and acted as symbols of innocence and purity in contrast to the war, the dirty city and industrialisation as such. At the same time, they embodied hope and confidence in the future at a time when everything else appeared fluid and dystopic. Lundh's many photographs of children are therefore not the only ones during this period. As Mathilda Hallberg has shown in her dissertation, Children on display, the interest in photographic representations of children was (and in many ways still is) immense, especially with regard to showing how the life of children ought to be in the modern welfare society. During the years 1930-1944, pictures of children were published in photo contests and photo books. The period between the 1930s and 1940s is a turning point in children's lives in society and the perception of childhood. According to Anne-Li Lindgren, social reform, institutionalised childcare and the growth of education had a significant impact on children's position in relation to the state (Lindgren 1999, see also Habel 2002). The photobooks presented, both in pictures and captions, a unified message which said that more and better children were needed if the nation was to have any chance of competing with other countries in the future. The pictures of children therefore served as tools to communicate 
political messages (Hallberg 2017:15, 88, 266, cf. Jönsson 2011). In addition, the pictures of children also worked as a means of unification for the nation as a whole. Since the future of the nation belonged to the children, the children were the ones who would take the nation into modernity.

\section{Framing Childishness}

A number of the photos in the collection show children in everyday situations. Furthermore, there are many pictures in Lundh's photo collection that depict children performing activities, for example bicycling and skating, as in the photograph below. In this sense, the photographs in Lundh's collection follow a genre-specific way to portray children (cf. Holland 2004). One theme recurrently featured in this genre is the portrayal of people who do something. The children are active. In comparison with earlier photographs of children, it is the vivid moments of everyday life that Lundh portrays and preserves (see for example Reinius 1986). The photographic moment thus does not entail a temporary interruption. This way of documenting and representing children (and adults) can be related to how people were portrayed before the small-screen camera's (in Lundh's case the Leica) entry into the professional life of the photographer. However, these new ways of portraying children also tell us something more than that new opportunities arose with the technical development of the camera. It is also about genre and societal power relations.

The British historian of child images Patricia Holland writes that during the first half of the twentieth century, it was typical of the progressive pedagogy to portray children as active and engaged, and the children were also in the foreground, and not the professionals or the adults (Holland 2004:80ff). It is, however, important to consider that the children were not portrayed as competent subjects, but rather captured through the professional gaze. Holland also points out that many photographs of children from the 1960s and 1970s showed children as energetic subjects fulfilling their childishness and learning at the same time (Holland 2004:82).

In taking a closer look at Lundh's pictures, apart from the fact that many children in general are active, there is a difference between the photographs of girls and boys. Boys are generally more active and playful in the photographs and often pictured along with bicycles, agricultural tools and other activity-promoting tools. The girls, on the other hand, are more often portrayed motionless in front of the photographer as if they are modelled: cute and attractive (cf. Holland 2004). There are some exceptions in the collection, but these are relatively few on the whole. Thus, many of Lundh's photographs of children show a polarised understanding of boys as contest-oriented and playful while the girls are portrayed as submissive 
and pleasing (cf. Heywood 2018:71). However, it is important to emphasise that the age of the child affects this. In general, small children regardless of gender appear in Lundh's pictures as cute, innocent and in a sense passive. Perhaps this can partly be attributed to practical difficulties in directing small children to perform in accordance to the photographers' vision and wishes. Letting the child sit still in front of the camera could have been the only opportunity to capture the child in the picture.

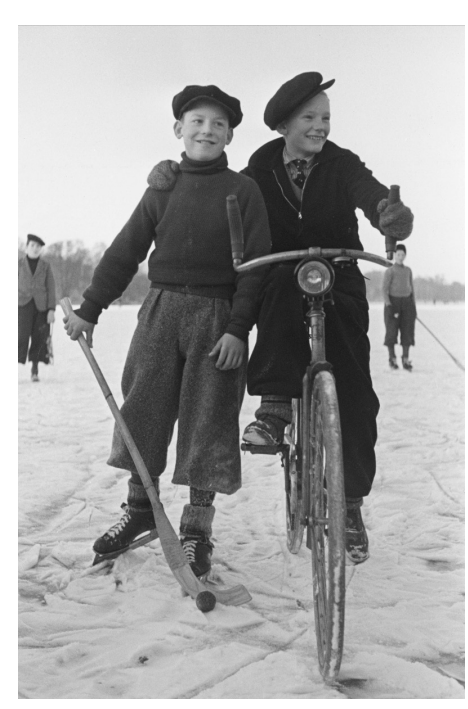

Fig 4. Two children on the ice. One skates and the other cycles, estimated time period 1935-1945 (NMA.0036071).

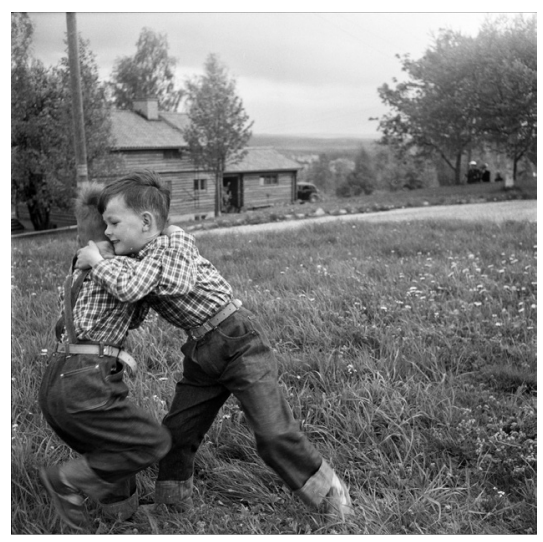

Fig 5. Two children in checked shirts and folded jeans are playing in the countryside, 1952 (NMA.0040872).

In the era of "the People's Home", it was of great importance to document children's play in photographs (cf. Hallberg 2017:195). In a photo series of a newly built housing complex constructed by HSB (a Swedish cooperative housing organisation started in 1923), which Lundh shot in 1934, a large portion of the pictures show special nurseries or kindergartens which were called "playschools". The archives demonstrate that Lundh visited several of these as there are eight playschools in Stockholm documented by him. In the beginning, these playschools, which developed into what is today called preschools, were built at the top of the relatively tall apartment buildings. The idea was that the children should be kept away from the exhaust gases of the streets and get as close as possible to the sun and the light. The playschools were a combination of kindergarten, day care and after-school centre to which every child who lived in the neighbourhood was welcome. The 


\section{Culture Unbound}

Journal of Current Cultural Research

HSB houses were built for workers and lower officials who previously had to leave their children at so-called children's cribs, which had acquired a bad reputation due to their lack of both financial resources and an educational focus (Bjurman \& Henschen 1990:203).

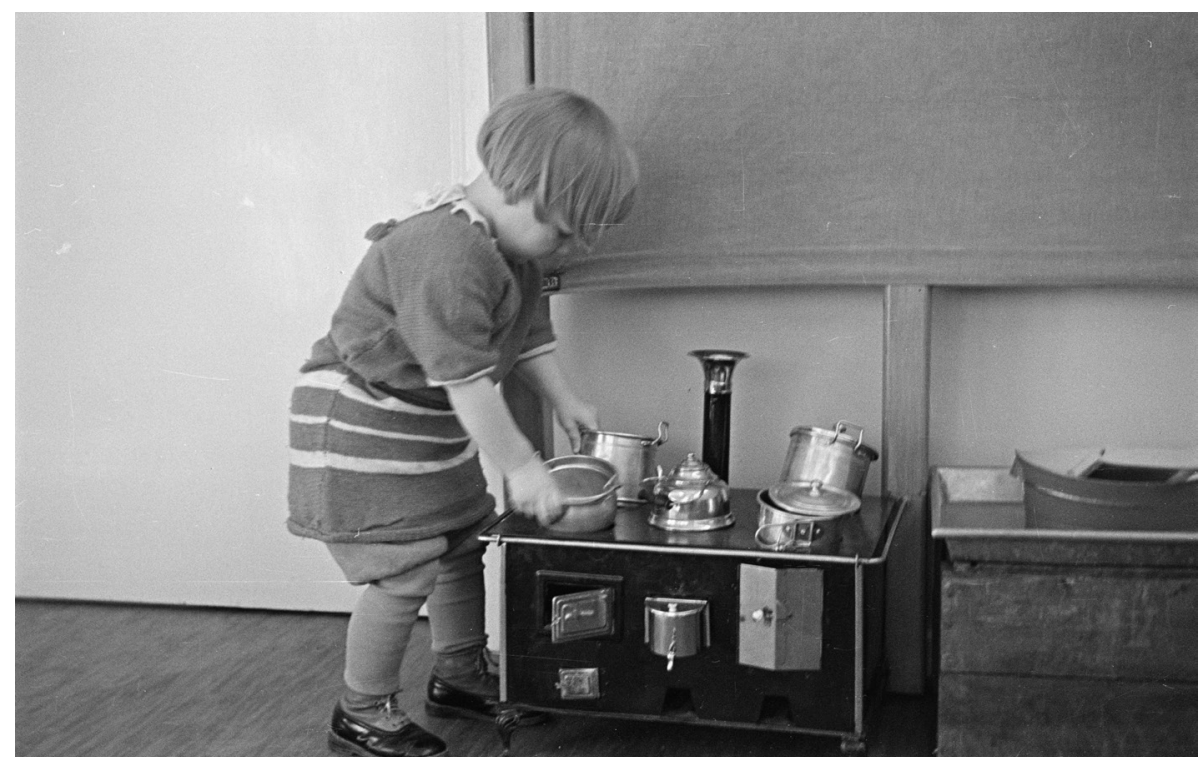

Fig 6. Child plays with kitchenware and stove, 1934, The HSB-housing at Skeppargatan, Stockholm (NMA.0082119).

In the pictures from the HSB "playschools", the children sleep, listen to fairy tales, sing songs, eat and play with toys specially designed for children. These included small stoves and crockery, rocking horses, cars, dolls, blocks, etc. The children look overwhelmingly satisfied and happy, even though some of them are sad and crying. Moreover, since the photographs are in a series, there are also some pictures that show the children being comforted by the professionals. There was thus a reason to also show the caring qualities of the professionals. Nevertheless, the pictures give an overall impression of a happy and meaningful existence at these new, bright, modern and child-centred playschools. We cannot know for certain, but Lundh probably took all these photos on order from HSB. The purpose was most likely to document the revolutionary and progressive ideas with child-adapted spaces and specially developed play tools for children.

To picture children as playful and childish, as Lundh's intentions seem to have been, should also be understood in the light of the idea of saving children from the inhumane older society in which children had to work in dangerous and damaging environments. Play is furthermore the antithesis of work and seriousness, which 
should also be related to the relatively recent ban on child labour at the time and discussions about child labour that had been going on for decades in Sweden and abroad (Sandin 2003).

\section{The Child in Nature}

In connection with the breakthrough of amateur photography in the late 1800s, children became, as mentioned earlier, popular motifs (Hallberg 2017:60). With new standards for composition and the pursuit of naturalness and movement in the picture, children embodied the idea of the natural and undecided that the amateur photographer wanted to capture with his camera (Dahlgren 2013:67ff). In addition, the small, handy camera gave the photographer an opportunity to catch the fleeting moment.

A large proportion of Lundh's photos of children show them in close contact with nature. The children are playing in the sand; they are lying on a flowerbed; they are skiing; or they are just posing with a tree or a rock and so on. The photographs convey a representation of nature as good and healthy: good in terms of space for fun and activities like bathing, running and nudity. Nature is also good in that it offers a selection of goodies like flowers, blueberries, apples, lingonberries and mushrooms. According to other research about photographs of children during the time when Lundh was active as a photographer, nature plays a significant role (Hallberg 2017:150). As the Swedish childhood researcher Gunilla Halldén writes, childhood and nature are linked to each other in an idea where nature is considered good for children and where children feel good being in nature (Halldén 2009). Equally important is the fact that many families, especially the working-class families in the cities, lived in overcrowded conditions, which both encouraged and forced the children to go outdoors. Influential debaters such as Alva Myrdal argued for the need of meaningful activities for children (Myrdal 1935). For the municipalities, this meant investing in play activities, playgrounds and outdoor activities in the city's parks and green areas (Hallberg 2017:189).

The fact that many of Lundh's photographs of children are taken during summer and winter, often outdoors surrounded by nature, is no coincidence (cf. Hallberg 2017:227). During the years 1929-1960, nature had a symbolic significance, especially with regard to children. At first, since the ideological concept of welfare was based on a strong conviction that modern society had to be inhabited by strong, healthy citizens, being outdoor in the fresh-aired nature became synonymous to this ideal (cf. Larsson, in this publication). Secondly, the close connection between children and nature has a long history. The idea of childhood and nature is derived from the romantic 19th-century tradition, which is found internationally but which is also considered to be particularly strong in 


\section{Culture Unbound}

Journal of Current Cultural Research

the Nordic childhood construction (Hedenborg 2018:307). Children are seen as closer to nature because of their status as not yet fully socialised and, in a sense, they are wilder and purer than adults. Analogously, children's closeness to nature has to do with their dynamic, rather than static, characteristics (cf. Aronsson \& Sandin 1996:194).

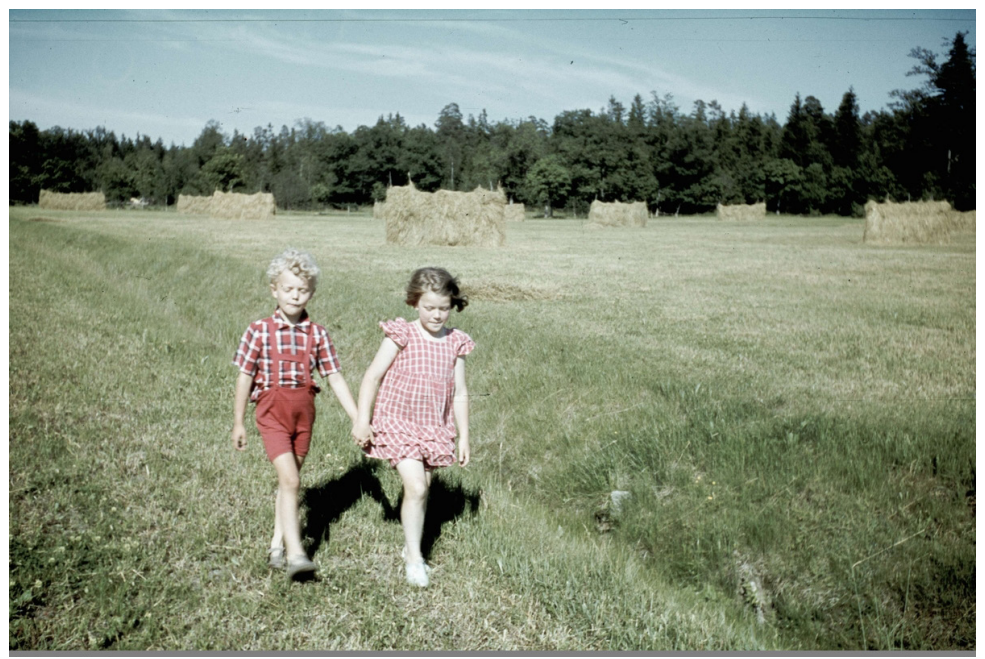

Fig. 7. Two children holding hands in a field, year unknown (NMA.0041759).

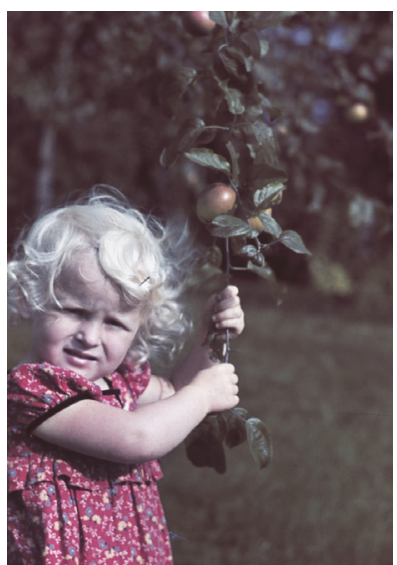

Fig. 8. Small child with floral dress holding a branch with apples 1942 (NMA.0061511).

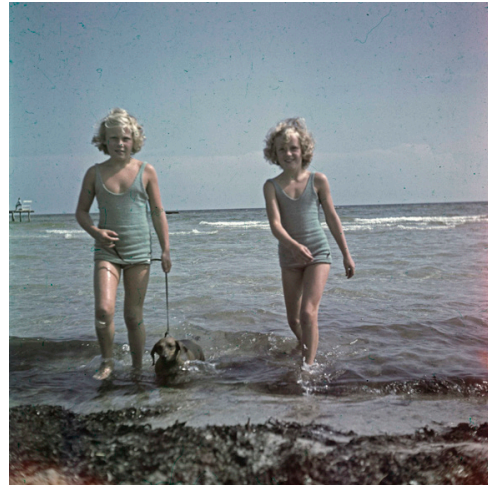

Fig. 9. Two children in swimsuits with a dog on a beach, estimated time-period 1948-1950, Skåne (NMA.0094983). 
The pictures showing children in close relation to nature and the city's organised playgrounds in Lundh's collection are closely connected with other visual representations from the same time period. In the photobook "Svenska barn i bild" from 1942, the state-run playgrounds in the cities are, for example, in focus (cf. Hallberg 2017:191).

\section{The Child as an Aesthetic Project}

The photographs of bathing children in the summer, playful children in sunny playgrounds, and the coherent story of healthy and well-nourished children in Lundh's photo collection must be read in contrast to other images of children and childhood: that of the poor, sickly, undernourished child that occurred in the philanthropic propaganda of the early twentieth century (Aronsson \& Sandin 1996:189). However, this image genre is not completely absent in Lundh's photo collection. There are clear traces of the ideal to depict children as vulnerable and exploited in Lundh's early photographs. This is also something that continues in Lundh's photographic production, but then it is illustrated by photographs of children with an ethnic origin other than Swedish. Raymond Williams has pointed out that at any point in history there exists 'residual' cultural forms, which linger from a previous age and are concurrent with 'emergent' forms in which new styles develop (Williams 1981, cf. Holland 2004:8f).

In order to contextualise Lundh's pictures, I have, as previously mentioned, studied other pictures and images of children from the same time-period. For example, the widespread and popular so-called photo books from this time have provided some insight. ${ }^{5}$ In the photographs of children during this period there are certain recurring ways of portraying children. The photo books stressed how the children in all their innocence must be protected from various forms of threats. These mainly consisted of the so-called population crisis and World War II. It was also in the light of these crises that the relationship between children and nation was actualised. In relation to the threats, children were positioned as national symbols and as expressions of a strong and viable Sweden (cf. Hallberg 2017: 222-223). Together with Billy Ehn and Jonas Frykman, the ethnologist Orvar Löfgren describes the emergence of a welfare nationalism that was largely about bridging class contradictions and an equalisation of class divisions. The state's responsibility was to take good care of all children (and all citizens). In that sense, the nation became part of a larger democratic project, where a healthy body, a functional home and nature were typically given as Swedish signatures (Ehn, Frykman \& Löfgren 1993). 


\section{Culture Unbound}

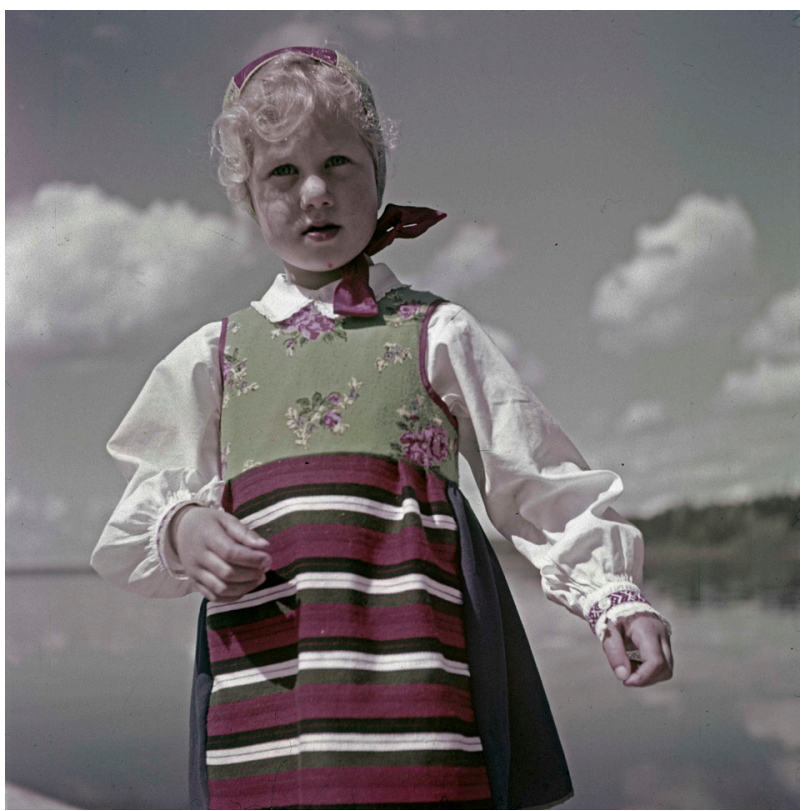

Fig. 10. Child in national costume, 1952, Rättvik (NMA.0094992).

Looking at the whole of Gunnar Lundh's photographs of children, it is obvious that he was influenced by this nationalistic project. Many photographs are taken in an idyllic and romanticised environment, such as Skansen and more authentic rural environments. In his collection there are several pictures where both children and adults are dressed in traditional Swedish regional costumes, as in the photo above. In the photo books mentioned above there are many pictures of children, especially girls, wearing "folk costumes". Hallberg writes that children in folk costumes visualise ideas about kinship and folk culture, and these representations serve as tools in the construction of national identity (Hallberg 2017: 232).

The photographs of happy, active and healthy children in close relation to both nature and the nation were central to the construction of the new modern society in which the children acted as symbols of the future. The art historian Jeff Werner shows how artistic images of light or white bodies in scenic surroundings become meaningful by representing something specifically Swedish. Werner argues that it is through these visual codes that we learn to recognise what is Swedish and what is not (Werner 2014).

Although this description and interpretation of Lund's photographic archive is reliable in many respects, it gives an overly unilateral picture that does not match the entire collection. Lundh also took other kinds of pictures, even though they also could be described as typical of the genre images of the "People's Home". 
In the collection there are several pictures of this kind. These include portraits of children in what is described on the contact sheet as a special school for Sami children (in Lundh's description, Lappskola), as well as a facility for so-called delinquent children (in Lundh's description, Vanföreanstalt) and a series of Roma children (in Lundh's description, Zigenare) in different camps.

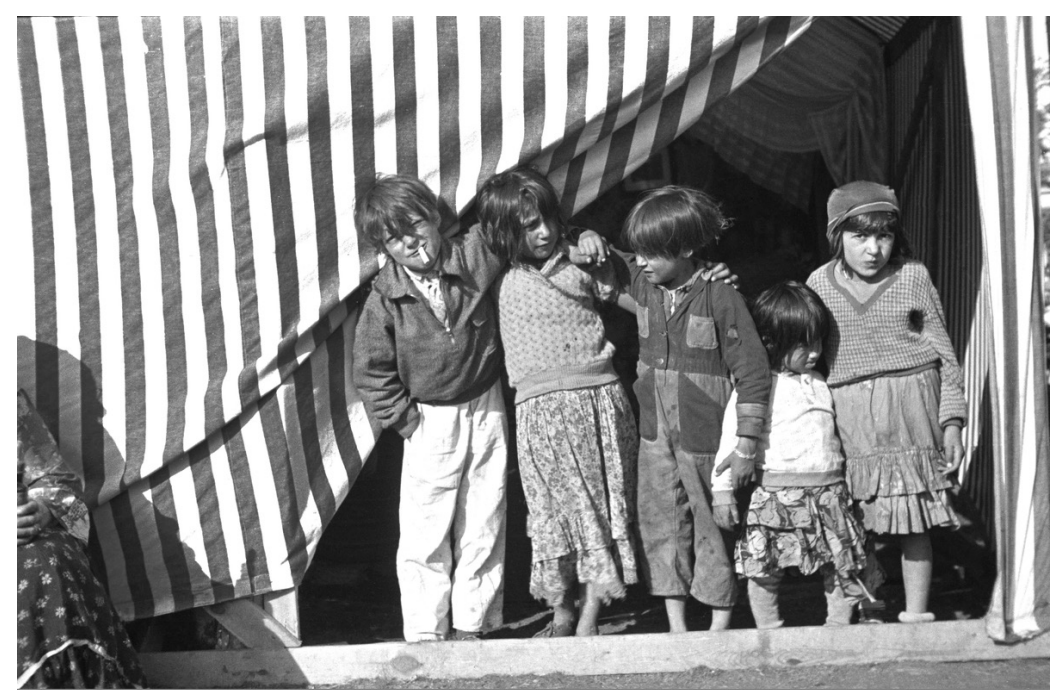

Fig 11. Five Roma children standing in front of a tent. The family Taikon camp, Johanneshov south of Stockholm, 1933 (NMA.0068925).

These photographs convey a different kind of childhood than the one I have shown so far. In these pictures, the children are not portrayed within the same harmonious, idyllic, romanticised and nationalistic frame as many of the other pictures of children. These pictures depict other ways of being a child and other conditions for childhood.

\section{Photographs as Documentary Evidence of their Subjects: Some Concluding Remarks}

The aim to say something essential about children's lives during the time period presented in the beginning of this article seems complicated only by reading the photographs. The widespread assumption that images, especially photographs, reveal what children were and how their lives were lived in the past is highly problematic. The forms and genres in which children and childhood have been represented in the past often overrides the motive for the photograph (Higonnet 2002:201). Based on my review, this is also the case in many of Lundh's pictures of children. Thus, a focus on how images of children were used for political 
and nationalistic purposes should also allow for them to be interpreted as cultural expressions. These expressions differ from traditional historiography by describing the images as neutral and documentary representations of life in Sweden (Strandroth 2009:106, cf. Becker 1992:16).

Hence, since Lundh's photographic collection contains pictures of such different character, including his more private pictures, there is a chance to gain knowledge of a historical childhood that goes beyond the repetitive representativeness of children during the welfare state's construction phase. In addition, his diligent photographing, no matter whether he was on duty or not, and the fact that he saved even the photos of poor quality, gives the archive researcher an overall impression of almost being there.

Many of Lundh's photos of children are taken during summer, winter and leisure time, which gives an overall view of childhood as carefree and happy. Gone are, for example, the serious portraits of working (productive) children who solemnly look right into the camera lens, which were considerably more common around the earlier turn of the century (see Flygare 2004, Lilieqvist 1990, Reinius 1986). From this period, Lundh's productive years and onward, childhood was increasingly portrayed in the fashion we recognise today. An understanding and specific way of seeing and portraying children and childhood became institutionalised during this period. However, in this institutionalisation process of images of childhood, Lundh's pictures of children seem to reproduce and enhance this "pictorial vocabulary" in many ways that appear natural to childhood (Waggoner 2002:150). In that sense, a contemporary resonance of the photographic forms from the constructional period of the welfare state is created here by comparing these pictures with contemporary pictures of children. In addition, the photographs by Lundh, in this case of children, are both recognisable, familiar and -in an ungraspable way-pleasurable. They certainly have an affirmative quality and a nostalgic aura that tells us a story about a society that in many ways has vanished. Through their familiarity and intertextuality, the pictures of children have gained a particular resonance as 'desired images' (cf. Holland 2004:7).

Helena Hörnfeldt is Associate Professor at the Department of Ethnology, History of Religion and Gender Studies at Stockholm University. Her research is focused on childhood studies within ethnology and cultural analysis. She has written on, among other things, children's fears, apocalyptic narratives and humans' affective relations with animals.This article is part of the project Images and Stories of Everyday Life (Vardagens bilder och berättelser), financed by The Royal Swedish Academy of Letters, History and Antiquities, and The Swedish Foundation for Humanities and Social Sciences. Email: helena.hornfeldt@etnologi.su.se 


\section{Culture Unbound}

Journal of Current Cultural Research

\section{Notes}

1 All photographs in the article are taken by Gunnar Lundh.

2 In this article, I use pictures and photographs synonymously. On the other hand, when using the term image, I refer to visual sources in general.

3 Swedish term applied for the concept of the welfare state.

4 The photobook "Svenska barn i bild" (Swedish Children in Images) (1942) was published by the editorial committee for Swedish children in pictures, which was composed of actors engaged in society's child issues (Hallberg 2017:43).

5 The photo books referred to here are: "1000 svenska barn" (1000 Swedish children) from 1930 (published by the newspaper "Svenska Dagbladet" as a result of a photo contest, "The best child image") and "Svenska barn i bild" from 1942 (see above).

\section{References}

Unprinted sources

Gunnar Lundh's photograph archive: contact sheets

\section{Printed sources}

1000 svenska barn (1930): Svenska Dagbladet. Stockholm: Nordisk rotogravyr.

Svenska barn i bild (1942): Redaktionskommittén för Svenska barn i bild,

Stockholm.

Sveriges barn Sveriges framtid (1942): (red.) Bibi Wennberg. Stockholm: IGO-förlag

\section{Literature}

Alanen, Lena (2009): "Generational Order", Qvortrup, Jens, Corsaro, William A. \& Honig, Michael-Sebastian (eds.), The Palgrave handbook of childhood studies, Houndmills, Basingstoke, Hampshire: Palgrave Macmillan.

Aronsson, Karin \& Bengt Sandin (1996): "The Sun Match Boy and plant Metaphors: A Swedish image of a $20^{\text {th }}$-Century Childhood", Philip C. Hwang et. al. (eds.). Images of Childhood. New Jersey: Lawrence Erlbaum Associates.

Becker, Karin (1992): "Picturing Our Past: An Archive Constructs a National Culture", The Journal of American Folklore, 105: 415, 3-18.

Becker, Karin, Ekecrantz, Jan \& Tom, Olsson (2000): "Introduction: Picturing politics in $20^{\text {th }}$ century Sweden", Becker, Karin, Jan Ekecrantz \& Tom Olsson (eds.) Picturing Politics. Visual and Textual Formations of Modernity in the Swedish Press. Stockholms universitet, JMK (Journalistik, medier och kommunikation) Skriftserien 2000:1, 8-25.

Bjurman, Eva Lis \& Helena Henschen, (eds.) (1990): Barn i stan: från sekelskifte till nittiotal, [Ny, rev. uppl.] Stockholm: Folksam.

Blomberg, Eva (2005): "Sätt att se", Historisk Tidskrift 125:2, 263-273.

Blomberg, Eva (2006): Vill ni se en stjärna? Kön, kropp och kläder i Filmjournalen 1919-1953, Lund: Nordic Academic Press.

Bringéus, Nils-Arvid (1981): Bildlore: studiet av folkliga bildbudskap, Stockholm: Gidlund.

Bringéus, Nils-Arvid (2007): Livets högtidsdagar, Stockholm: Carlssons.

Cunningham, Hugh (1991): The Children of the Poor: Representations of Childhood since the Seventeenth Century, Oxford: Blackwell. 


\section{Culture Unbound}

Journal of Current Cultural Research

Cunningham, Hugh (2006): The invention of childhood, London: BBC Books.

Dahlgren, Anna (2013): Ett medium för visuell bildning: kulturhistoriska perspektiv pà fotoalbum 1850-1950. Göteborg: Makadam.

Ehn, Billy, Frykman, Jonas \& Orvar Löfgren (1993): Försvenskningen av Sverige: det nationellas förvandlingar, Stockholm: Natur och kultur.

Ekström, Simon (2017): Humrarna och evigheten: kulturhistoriska essäer om konsumtion, begär och död, Göteborg: Makadam.

Eriksson, Bengt Erik \& Qvarsell, Roger (2003): "Samhället på bild - den tidiga socialvetenskapen och det dokumentära fotografiet", Meeuwisse, Anna \& Swärd, Hans (eds.): Den ocensurerade verkligheten i reportage, bild och undersökningar, Stockholm: Carlsson, 103-120.

Fahlander, Fredrik (2011) (ed.): "Inledning”, Spåren av de små: arkeologiska perspektiv på barn och barndom, Stockholm: Institutionen för arkeologi och antikens kultur.

Flygare, Iréne (2004): "Tre generationer 1900-talsbarn", Sjöberg, Mats (ed.): Jordbrukets barn: barns och ungdomars fostran i agrara miljöer, Stockholm: Nordiska museets förlag, 196-209.

Habel, Ylva (2002): Modern Media, Modern Audiences: Mass Media and Social Engineering in the 1930s Swedish Welfare State, Diss, Stockholm: Aura.

Hallberg, Mathilda (2017): Barn till beskådan. Familj, välfärdsstat och nation i fototävlingar och fotoböcker 1930-1944, Diss, Linköping: Linköping studies in arts and science, No. 713.

Halldén, Gunilla (ed.) (2009): Naturen som symbol för den goda barndomen, Stockholm: Carlssons.

Heywood, Colin (2018/2005): Barndomshistoria, Lund: Studentlitteratur.

Hedenborg, Susanna (2018/2005): Svensk barndomshistoria. Heywood, Colin (ed.): Barndomshistoria, Lund: Studentlitteratur.

Higonnet, Anne (2002): "What do you know about children?" Brown, Marilyn R (ed.): Picturing Children. Constructions od Childhood between Rousseau and Freud, Aldershot: Ashgate.

Higonnet, Anne (2013): "Picturing childhood in the modern west", Fass, Paula S (ed.): The Routledge History of Childhood in the Western World. London: Routledge.

Hirdman, Yvonne (2000/1989): Att lägga livet tillrätta - studier i svensk folkhemspolitik, Stockholm: Carlssons.

Holland, Patricia (2004): Picturing Childhood: The Myth of the Child in Popular Imagery, London: I. B. Tauris.

Hörnfeldt, Helena (2009): Prima barn, helt u.a. Normalisering och utvecklingstänkande i svensk barnhälsovård 1923-2007, Diss, Göteborg/Stockholm: Makadam.

Hörnfeldt, Helena (2015):” Med barnets bästa i fokus - förändrade relationer mellan stat och familj under 1900-talet", Fronesis-Politik. Teori. Kritik, 50-51, 87-96.

Jönsson, Mats (2011): Visuell fostran. Film- och bildverksamheten i Sverige under andra världskriget, Lund: Sekel.

Larsson, Marianne (2008): Uniformella förhandlingar: hierarkier och genusrelationer i Postens kläder 1636-2008, Diss. Stockholm: Nordiska museets förlag.

Leipe, Lena (2001): "Konst som historiskt källmaterial?", Andersson Lars M, Lars Berggren \& Ulf Zander (eds.): Mer än tusen ord. Bilden och de historiska vetenskaperna, Lund: Nordic Academic Press.

Liliequist, Marianne (1991): Nybyggarbarn: barnuppfostran bland nybyggare i Frostvikens, Vilhelmina och Tärna socknar 1850-1920, Diss. Umeå: Univ.

Lindgren, Anne-Li (1999): "Att ha barn med är en god sak": barn, medier och medborgarskap under 1930-talet, Diss. Linköping: Univ.

Myrdal Alva (1935): Stadsbarn. En bok om deras fostran i storbarnkammare, Stockholm: Kooperativa förbundets bokförlag. 


\section{Culture Unbound}

Journal of Current Cultural Research

Olsson, Tom (2000): "Den politiska föreställningen", Becker, Karin, Jan Ekecrantz \& Tom Olsson (eds.) Picturing Politics. Visual and Textual Formations of Modernity in the Swedish Press. Stockholms universitet, JMK (Journalistik, medier och kommunikation) Skriftserien 2000:1, 80-105.

Peacock, Margaret (2014): Innocent Weapons. The Soviet and American Politics of Childhood in the Cold War, Chapel Hill: The University of North Carolina Press.

Petersen, Anja (2007): På visit i verkligheten. Fotografi och kön i slutet av 1800-talet, Brutus Östlings Bokförlag Symposion.

Pollock, Linda A. (2002). "Foreword." Brown, Marilyn R (ed.) Picturing Children. Constructions od Childhood between Rousseau and Freud, Aldershot: Ashgate.

Reinius, Gunnar (1986): Bilder från barndomen, Stockholm: Prisma.

Sandin, Bengt (2003): "Barndomens omvandling - från särart till likart". Sandin, Bengt \& Gunilla Halldén (eds.): Barnets bästa. En antologi om barndomens innebörder och välfärdens organisering, Eslöv: Brutus Östling bokförlag Symposion.

Sandin, Bengt (2012): "More Children of Better Quality. Pricing the Child in the Welfare State", Sparrman, Anna, Bengt Sandin \& Johanna Sjöberg (eds.): Situating Child Consumption. Rethinking Values and Notions of Children, Childhood and Consumption, Lund: Nordic Academic Press.

Sekula, Allan (2003): "Reading an Archive. Photography Between Labour and Capital", Wells, Liz (ed.): The Photography Reader, London/New York: Routledge.

Strandroth, Cecilia (2009): "På forskningsresa i det digitala bildarkivet: ett brukarperspektiv", Dahlgren, Anna \& Pelle Snickars (eds.): I bildarkivet. Om fotografi och digitaliseringens effekter. Kungliga biblioteket: Mediehistoriskt arkiv 13.

Tagg, John (1993): The Burden of Representation. Essays on Photographies and Histories, Minneapolis: University of Minnesota Press.

Waggoner, Diane (2002): "Photographing Childhood: Lewis Carroll and Alice", Brown, Marilyn R (ed.) Picturing Children. Constructions od Childhood between Rousseau and Freud, Aldershot: Ashgate.

Werner, Jeff (2014): "Introduktion". Werner, Jeff \& Björk, Tomas (eds.) Blond och blåögd. Vithet, svenskhet och visuell kultur, Göteborg: Göteborgs konstmuseum.

Williams, Raymond (1981): Culture. London: Fontana. 


\title{
Images of Leisure and Outdoor Activities in the 1930s: A Mixed Archive Sources Methodology
}

\author{
By \\ Marianne Larsson
}

\begin{abstract}
In Sweden, leisure time and outdoor activities were important parts of the 1930s welfare society. The aim of this study is to examine the usefulness of some different source categories in the Nordic Museum's collections and to complement representations of 1930s ideals about health, leisure time and outdoor activities. The article is written within the scope of the Nordic Museum and Stockholm University research project Images and Stories of Everyday Life. With digitising as an overall purpose, the project focuses on two categories of source material in the museum collections-the responses to the museum's questionnaires and the photograph archive of the Swedish photographer Gunnar Lundh. Methodologically, around 400 questionnaire responses and 2,000 contact sheets have been looked at, with the aim of finding relevant representations of people's leisure time and outdoor life in the 1930s. A selected number of questionnaires are analysed, and regarding the photographs, four series are analysed and represented by a selected number of photos. Series of photos on Gunnar Lundh's contact sheets are essential, as they add knowledge beyond the individual photo. The combination of sources used in the article supports that holidays and outdoor life were part of urban people's lives, while for rural people it was not easily combined with living conditions in agriculture. These results are reflected in the museum's source material as well as in official government reports, earlier studies and historical sources. Although there is quite a large difference between the source categories, this study shows that the museum material, including evaluation of sources, makes it possible to broaden the image of Swedish people's outdoor activities in the 1930s. The bricolage research method indicates that combinations of sources enlarge the image of different groups' relationships to outdoor life.
\end{abstract}

Keywords: Leisure time, Holidays, Outdoor activities, Photographs, Questionnaires.

Larsson, Marianne: "Images of Leisure and Outdoor Activities in the 1930s: A Mixed Archive Sources Methodology", Culture Unbound, Volume 12, issue 1, 2020: 90-115. Published by Linköping University Electronic Press: http://www.cultureunbound.ep. liu.se 


\section{Introduction}

In Sweden, leisure time and outdoor activities were important elements of the 1930s welfare society. In this article, I will investigate how leisure time, holidays and outdoor activities are represented in archive sources such as photographs and questionnaire responses. The purpose is to investigate how a combination of different source categories can deepen the understanding of 1930s ideals about health, leisure time and outdoor activities.

The article is written within the Nordic Museum and Stockholm University research project Images and Stories of Everyday Life (Vardagens bilder och berättelser, henceforth VBB). With digitising as an overall purpose, VBB focuses on two categories of source material in the Nordic Museum collections. One is responses to the museum's questionnaires, delivered since the 1920s. The other is the Swedish photographer Gunnar Lundh's (1898-1960) photograph archive. Both collections contain a huge number of documents from around the same period of the twentieth century. I have limited my research to the 1930s, when the issue of people's leisure time exploded. With keywords such as holidays, leisure time and outdoor activities, I will identify and analyse representations of everyday life in these two source categories. Focus is on the content of the source material rather than its materiality or archive context, but not exclusively.

As complementary sources, I use two official government reports from the same period: the first is the committee report on the Annual Leave Act (SOU 1937:49); the other, Fritidsutredningen (The Leisure Time Report), is about establishing open-air recreation reserves (SOU 1940:12). These reports go hand in hand with the outdoor exhibition Fritiden, called the Modern Leisure Exhibition in English, shown in Ystad in 1936. There is no lack of research on the question of leisure time and outdoor activities. See, for example, Lena Eskilsson's articles about the ideas of the Fritiden exhibition as well as the Swedish history of outdoor activities (Eskilsson 1995, 2008, see also Pihl Atmer 1998; Sandell \& Sörlin 2008). Additionally, Jonas Frykman (1992) points out that the issues of health, outdoor life and a body in motion were important for many western countries between the World Wars, but had a particularly strong position in Sweden, both in the construction of the welfare state and, in a wider class perspective, in people's minds. My contribution will be to examine what kind of representations the museum's source material can provide of the 1930s discourse on leisure time and outdoor activities.

\section{Included or excluded in the benefits of the welfare state}

In 1930, when a permanent working hour law was established, it meant eight hours of work, eight hours of rest and eight hours of leisure time. In a historical 
perspective, leisure time was a new phenomenon. In 1932, the Social Democratic Party came to power, launching the ideas of a Swedish welfare state. The party's ideological ambitions were that Sweden would be a modern democratic society and a good "home" for every citizen. As a major social change, the first Swedish Annual Leave Act was established in 1938, created especially with regard to working class families. The innovative public act meant that almost all employees would receive twelve days of paid leave per year. In fact, the Swedish word for holidays (semester) actually came to mean paid leave, according to the previous official government report (SOU 1937:49: 105).

The newly established eight-hour day and the regular Sunday rest were important, but it was not enough, the official report stated. Free time and full rest for a longer period was considered necessary for the health of the workers, both in bodily and spiritual terms. An important part was also to prevent accidents during work. The issue of health was not the only idea; another aim was for workers to have time to devote themselves to interests that they would not otherwise have time to engage in. One example was opportunities to engage in outdoor activities or to acquire new impressions through travelling (SOU 1937:49: 104-116). The Annual Leave Act came into force on July 1 1938. For the first time, working class families had the legal right to spend two free weeks together. In many ways, this was a cultural change that affected people's lives.

However, as a part of the welfare project's ambitions to educate good citizens, the issue of leisure time was problematized. An important question concerned how working class families should spend their holidays in the best possible way. Holidays should not be wasted on frivolous activities such as dancing and immoral movies or laziness and idleness; they should be devoted to education, culture, fresh air and vitalising outdoor activities. The employees' leisure time became a challenge for the modern Swedish society. On the other hand, far from everyone was affected by the Annual Leave Act. The official government report states that the Annual Leave Act and paid holidays would not include independent entrepreneurs (SOU 1937: 49: 116). People running their own businesses were excluded, for example the large number of farmers. Another excluded group was the around one million unpaid housewives (Eskilsson 1995: 26).

As Swedish natural resources, namely iron and wood, have for centuries generated large export revenues, nature was an important component of the national identity. Nature tourism and outdoor activities were consequently important elements of society's attempt to increase the productivity of the working class, as well as their quality of life (Sandell \& Sörlin 2008: 64-65). The aim was to raise strong and healthy citizens. An essential part of the ideology was to encourage and take responsibility for people's leisure time, with health, body and outdoor recreation as important elements. This phenomenon was not unique 
to Sweden; in Norway, the eight-hour day was introduced in 1919, and an Annual Leave Act was established in 1937. With the same rhetoric as in Sweden, the issue of how to teach people to use their leisure time in the right way was one of the big social questions of the time (Lyngø 1993: 22-24).

\section{Analysing Series of Photos: Showing a few Pictures}

As an elementary way to identify photos of outdoor activities, I browsed around 2,000 contact sheets in chronological order to perceive the flow. As there are around 30-36 photos on each contact sheet, I looked at around 70,000 contact prints. "Reading" the contact prints was a pleasure, although it took a lot of time. It was not hard to find photos of people swimming, cycling, sailing, camping and enjoying leisure time and fresh air. Among thousands of photos, with a huge number showing outdoor activities, I decided to work with four photo series which express my theme and keywords. My intention is to analyse and draw conclusions from a series of photos, although only a few examples are published in the article.

An important manifestation of the authorities' efforts to educate the citizens in positive holiday habits was the outdoor exhibition Fritiden in 1936 in Ystad, Skåne. As Gunnar Lundh was born in Skåne, and obviously fond of photographing outdoor activities, I was not surprised to find that he documented the Fritiden exhibition. Consequently, Lundh's series of photos of this occasion will work as a constructive starting point for the analysis. According to his series of photos and the frugal notes on the contact sheets, he visited the exhibition over two or three days in the middle of July. There are only a few people moving around in the exhibition area; it looks like it was a bit windy and chilly, as some are wearing coats and hats. The photo series, including around one hundred photos, show the exhibition pavilions, parks, plants, ponds, ornaments and areas for outdoor activities. Additionally, a lot of photos show information panels with text and photomontages. Lundh's photos of the panels look instructive, but sometimes a little tilted and blurred, without obvious aesthetic ambitions. As I, to start with, only had access to the contact sheets, I could not read the texts. To get a closer look at the message of the exhibition, I had to order high-resolution digitised photos.

According to the VBB project's purpose of making Lundh's photos available to the general public, I ordered all the photos in the series from the exhibition. The two sceneries published below are the very first photos in the series; in this article they are meant to introduce the reader to the exhibition area. From the series, I know that the entrance is situated behind the flagpoles and the big introduction panel on the first photo. The second photo shows the arched building containing the main restaurant, which was built for the exhibition and still remains, today holding a sports hall. 


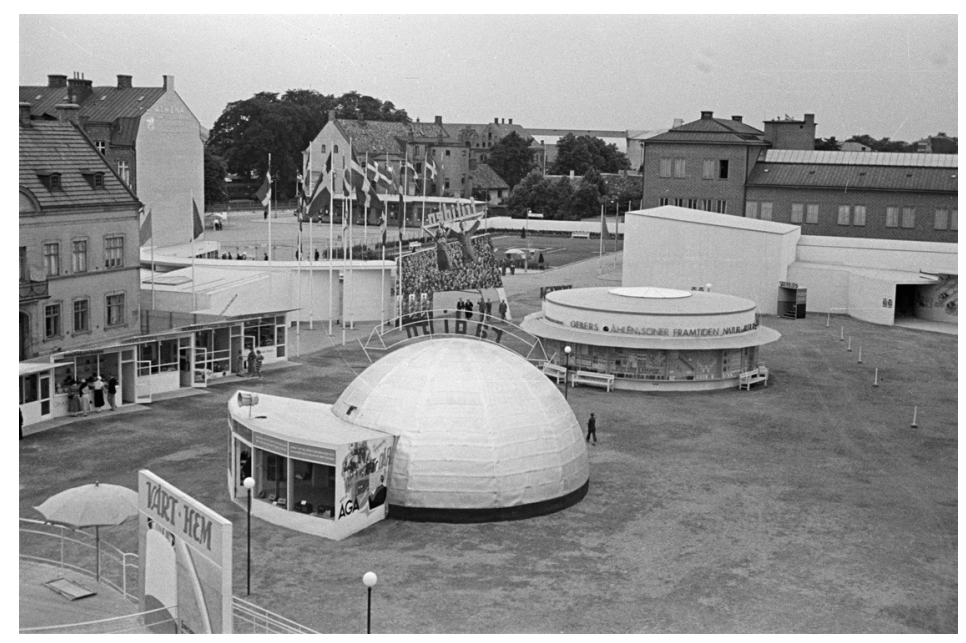

Fig. 1 View over exhibition pavilions and behind them, the introduction panel and the entrance of the Modern Leisure Exhibition (Fritiden) in Ystad, July 15/16 1936. Photo: Gunnar Lundh (NMA.0078752).

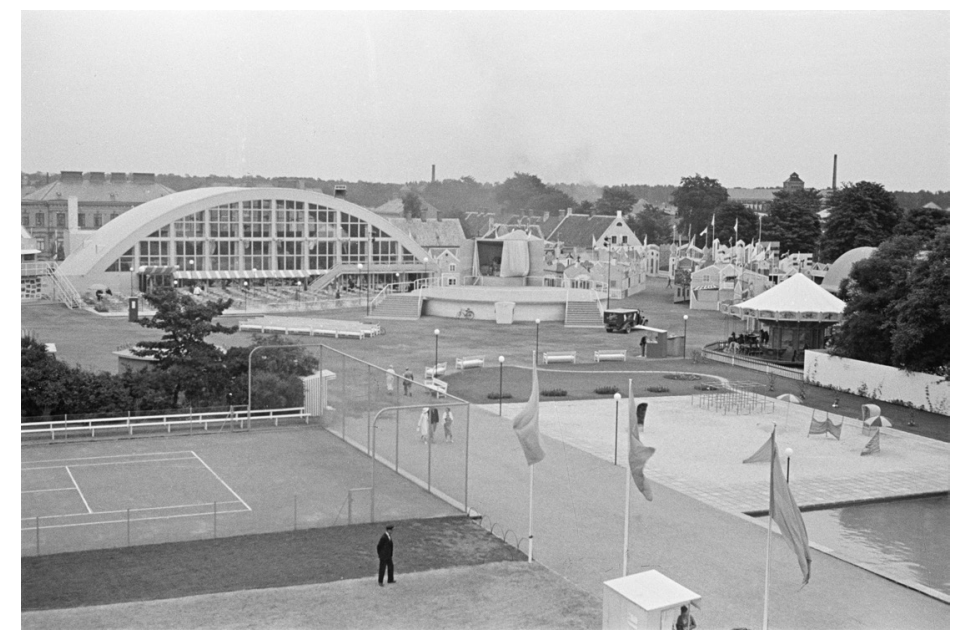

Fig. 2 View of the exhibition area, with a tennis court in front and the arched building containing the main restaurant in the background. Fritiden, July 15/16 1936. Photo: Gunnar Lundh (GL.113332).

The Fritiden exhibition was on display between June 19 and August 23 1936, and was arranged by Ystad municipality in collaboration with the Swedish Handicraft Association (Svenska slöjdföreningen). ${ }^{1}$ In the press, the exhibition was noted as an attempt to highlight a current social problem expressed in modern exhibition design. The indicated problem was that leisure time and holidays must not be wasted on bad activities, while the innovative photomontages represented the modern exhibition design (Eskilsson 1995; Svenska Dagbladets Årsbok 1936: 77). 
As the modern view of leisure time caused concerns among politicians, authorities, public educators and psychologists, Fritiden was arranged with aspirations to teach people how to use their leisure time and holidays in the best possible way. According to the catalogue, the exhibition would illustrate the idea of leisure time. As a part of communal benefit and democracy, a proper use of leisure time should make people happy and healthy, as was the current ideal for modern humans (cf. Eskilsson 1995). The English version of the exhibition catalogue expresses the idea like this:

If the people are unable to fill up their leisure hours in such a way that they derive health and pleasure from it, then it is for the community to help them by advice and action, give them the possibility of spending their leisure time in a richer, finer and more profitable manner. The leisure time in this way becomes a concern of the community with an importance as great as that of working time (Modern Leisure 1936: 20).

Details that are possible to read on the high-resolution photos show that the visitors were met at the entrance with a series of large panels with photomontages and text information. One of the headlines emphasises that the modern leisure problem was born with industrialization, and another points out that leisure time strengthens muscles and minds with sports and outdoor life. The exhibition gave detailed information on how working class people (and other visitors) should use

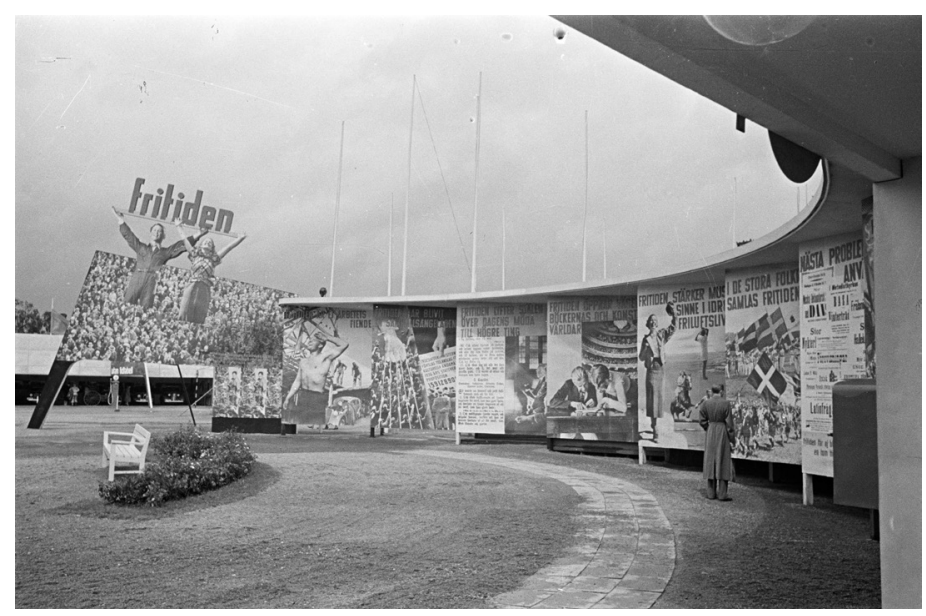

Fig. 3 The introduction panels with their innovative photomontages met the visitors inside the entrance. To the left, the main panel showing a young couple stretching their arms in the air, while standing in a crowd of (primarily) men. Fritiden, July 17 1936. Photo: Gunnar Lundh (GL.113348). 


\section{Culture Unbound}

Journal of Current Cultural Research

their leisure time; panels on different outdoor activities were combined with facts about hobbies like photography and philately, church activities, bank savings and book publishing, newspapers and journals. Other panels referred to travelling by car, bus, train, boat and airline. The tone was inspirational and educational.

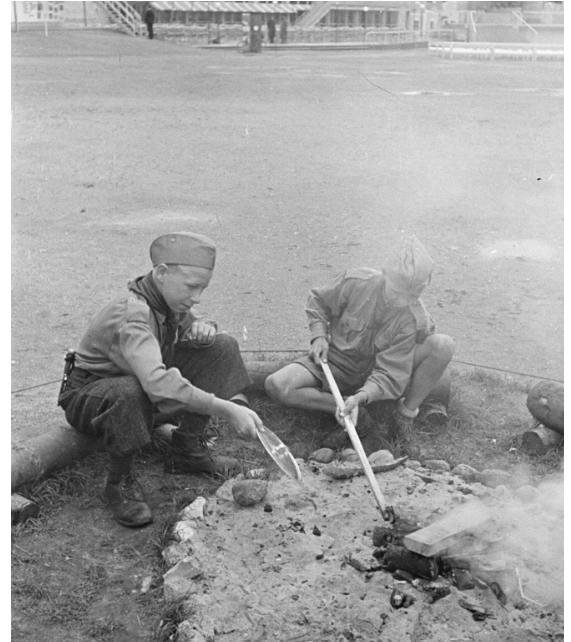

Fig. 4 Two boy scouts keep the campfire alive. As inspiration to go hiking and camping, scouting was a vital element of the exhibition. Fritiden, July 16/17 1936. Photo: Gunnar Lundh (GL.113365).

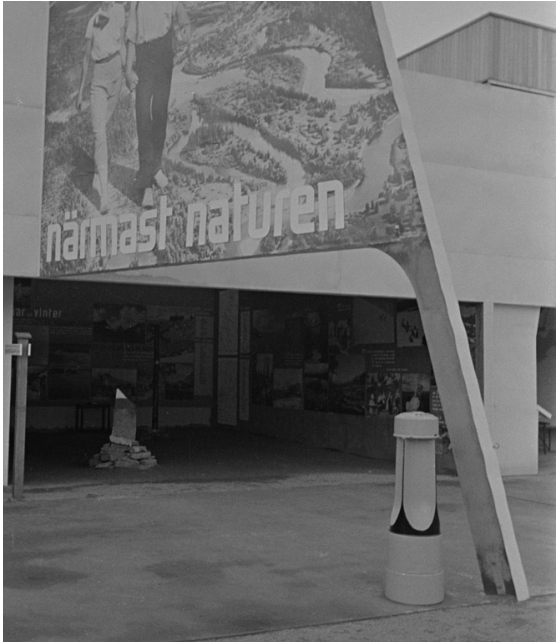

Fig. 5 The panel "Closest to Nature" shows a photomontage of a young couple hiking in nature, dressed in outdoor clothing. The photo series shows that there are further displays in the dark area behind the panel. Fritiden, July 16/17 1936. Photo: Gunnar Lundh (GL.113411).

As Lena Eskilsson expresses it, the exhibition was primarily addressed to men, as men were associated with their work while women were the heads of the home sphere. Still, young women are seen hiking in the landscapes or relaxing on the beach, illustrating the healthy outdoor life. In fact, a young woman wearing a swimsuit or sundress was used as a logo on the posters and on the cover of the catalogue. Standing in a crowd of people (mostly men) she raises her arms in the air. Even if it cannot be discerned in the photo series, associations for housewives had reacted strongly to not being invited to participate in the exhibition. As these women had no possibility of receiving paid holidays, or going on holidays at all, they had obviously not been considered. After some agitation, which was well noted in the press, they were invited to participate at the very last moment (Eskilsson 1995: 25-29, Svenska Dagbladets Årsbok 1936: 76-77). 
The exhibition attracted around 350,000 visitors during the summer and, visibly, Gunnar Lundh was one of them. The photo series shows that the Stockholm Association of Photography (Fotografiska Föreningen, Stockholm) was represented, and Lundh was probably interested in the innovative photomontages as well. Either way, as a news reporter, he contributes to the image of the 1930s leisure time discussions.

\section{Gunnar Lundh and the Documentary Impulse}

By browsing the contact sheets, I have followed Gunnar Lundh travelling around, both in Stockholm where he lived and in the countryside. Following the flow of the contact sheets is like experiencing the 1930s as a movie, directed by Lundh himself. Due to the selection of series and photos, this article also involves my interpretation of Lundh's photographic work. Since outdoor activities are a major theme in Lundh's photo archive, I limited the quantity of selectable photos to his black-and-white, small-format photos from the 1930s. During this decade, the Annual Leave Act was in progress as well as the official report about recreation reserves. During this period, Lundh participated in a variety of outdoor activities bringing his cameras with him. Despite his careful arrangements, with contact prints mounted on designed binder pages, the notes about the photos are sparse. A year is usually given, as are the locations where the photos were taken, but the names of the people depicted are seldom included.

Gunnar Lundh was born in Skåne and moved to Stockholm in 1930 (cf. Steinrud in this issue). While working in his new home town, he documented ordinary city life, and according to his choice of photo subjects-modern city buildings, parks, suburbs and other facilities-he was obviously inspired by modern society and, in fact, outdoor activities were expressions of modernity as well. It was all about the modern human being's health and life quality as an important part of democracy and the growing welfare society. Lots of photo series show that Lundh often participated in outdoor activities within organised groups. He went on walking, skiing and biking tours; he participated in boat trips and mushroom excursions. The photos express the modern outdoor activities of the time in inspirational ways even though we do not know who the depicted people are or which socioeconomic group they belong to. We do not know if people are on holidays or if they are on a weekend trip, and we do not know if Lundh participated in the excursions primarily in view of his commercial photo agency or for his own well-being. Probably it was a fruitful combination. As Lundh was running his own business, the Annual Leave Act did not include him; he had no paid holidays. 
In the summertime, Lundh often made excursions in wide circles from his childhood home in Mölle, in Skåne, by bike or, later, by car. Locals, tourists, landscapes, farmers' traditional work and the Swedish Tourist Association's (STF) youth hostels are recurring themes in the photos, and he seems to visit a number of beaches. Maybe his focus on beaches and swimming can be traced to his upbringing in the 1910s, when his father, the photographer Peter P. Lundh, earned some money by taking photos of groups of freethinking men and women swimming and enjoying themselves on the beach at Ransvik near Mölle (cf. Larsson 2011, 2014, Ranby 2013). Inspired by his father, Lundh started his education as a photographer in his younger years.

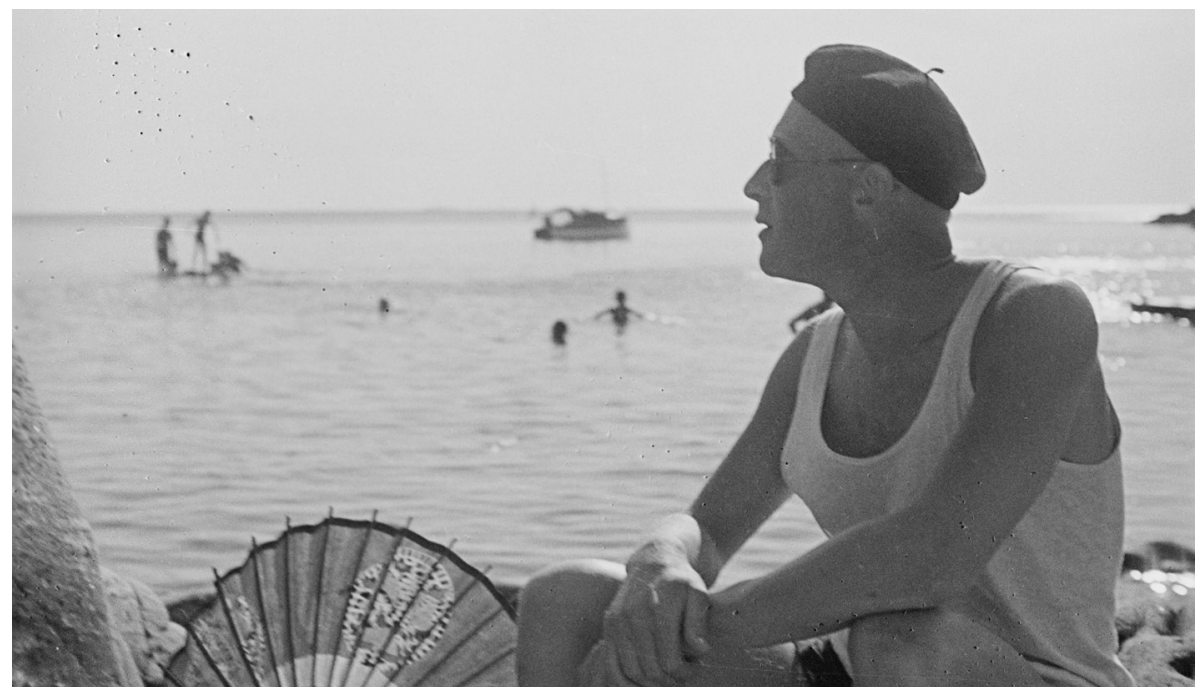

Fig. 6 Gunnar Lundh dressed in leisure wear and beret. Self-portrait on the beach in Ransvik, Skåne, 1934. Photo: Gunnar Lundh (GL.81347a).

Gunnar Lundh seems always alert to photograph subjects that appear in front of him: expressive people, beautiful landscapes, glittering seas and unexpected events. Like many photographers, Lundh visualised the surroundings through his camera, noticing occasions that might otherwise pass him by. The photographer Stuart Franklin calls an approach like this "documentary impulse". He uses this concept to describe the photographer's passion to preserve experienced moments, things they witness and might want to reform, or people, places or things they find remarkable. "The driving factors behind this impulse throughout history have included curiosity, outrage, reform, ritual, self-assertion and the expression of power," Franklin writes. "These factors encompass the search for evidence, for beauty, even for therapy-and always the search to make memorials immortal" 
(Franklin 2016: 5). According to his impressive and lively photo archive, Lundh should be seen as a documentary photographer. ${ }^{2}$ Franklin adds that documentary photography is a question of more prosaic impulses as well; for instance, making money. As one of the first photographers in Sweden to organise a commercial photograph agency, money was of course important to Lundh (Söderberg \& Rittsel 1983: 271). Most likely, his work could be both impulsive and well-planned.

It was Gunnar Lundh's innovative, small-format Leica camera that made the impulsive photography possible, even though he often carried with him his camera case containing a number of cameras. The Leica was introduced in 1925 and Lundh bought his in Germany in 1927 (Ranby 2013: 12). Designed for roll film, the camera was so small and handy that it could easily be kept in the pocket. Internationally, the Leica broke through as a press photographer camera around 1930. At the time, Lundh was the only Swedish photographer who used a small-format camera. In contrast to the still dominant bellows cameras that used glass plates, the Leica could be used relatively discreetly and the photographer could more than ever catch movement in flight, as the photo historians Rolf Söderberg and Pär Rittsel highlight (1983: 261). Lundh was early in his use of colour slides as well, not least when he documented outdoor activities. In contrast, when his father photographed bathers in the 1910s, he had to use a big bellows camera balancing on high legs on the pebble beach.

\section{Story-telling by a Series of Photographs}

On 25 September 1938, Gunnar Lundh participated in a mushroom gathering excursion to Adelsö on lake Mälaren. Among several inspiring photo series, I have chosen to analyse this one, as it visualises in a telling way outdoor activities in the 1930s. The fact that such a crowd of people walked into the forest made me curious. On the contact sheets, Lundh has noted by hand that they went to Adelsö by the SS Viking to pick mushrooms. The excursion is depicted on 119 contact prints (all ordered as high-resolution digitised photos) mounted on four contact sheets. Apart from the date, two names of depicted persons and a note about a small Adelsö ferry, there is no other information but the photos. Nevertheless, a worthwhile story about outdoor activities is visualised.

The SS Viking departs Stockholm from the quay near Stockholm City Hall, with a crowd of men and women on board. Arriving at Adelsö, the people walk into the woods with baskets in hand, climbing over fences and passing open fields. They are filling their baskets with mushrooms and they are showing each other their finds; they are talking and laughing. During a break, maybe for lunch, some are looking in a book, probably a mushroom handbook. Some of the women wear skirts, wool jackets and hats, stockings and walking shoes, while others wear short 
sports jackets, plus forts and boots. Some of the men are wearing suits, others jackets and plus fours. Some are wearing more casual clothes than others. One man, on the contact sheet named as "Hugo Stellin" (sic), looks a bit different as he is wearing a hat and a three-piece suit with a tie. The man is depicted in several photos; the situations and his authority indicate that he is the expert and perhaps the leader of the group. ${ }^{3}$

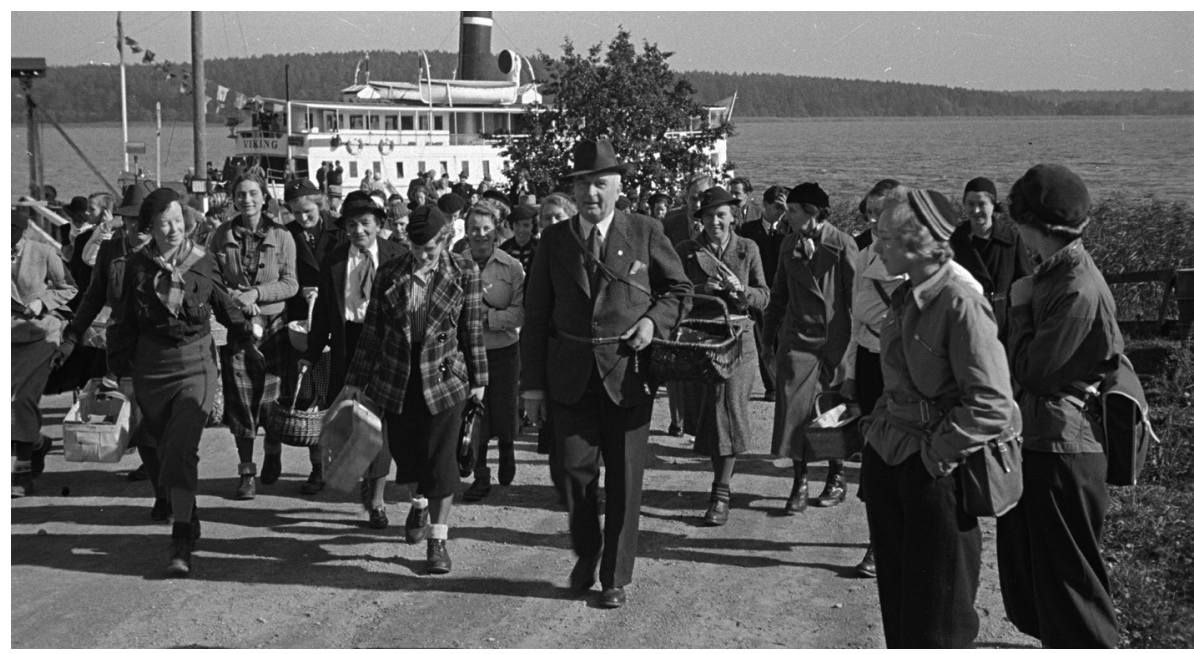

Fig. 8 The mycologist Hugo Stelin (dressed in three-piece suit) leads the crowd of mushroom pickers as they are leaving the SS Viking at Adelsö, September 251938. Photo: Gunnar Lundh (GL.131061).

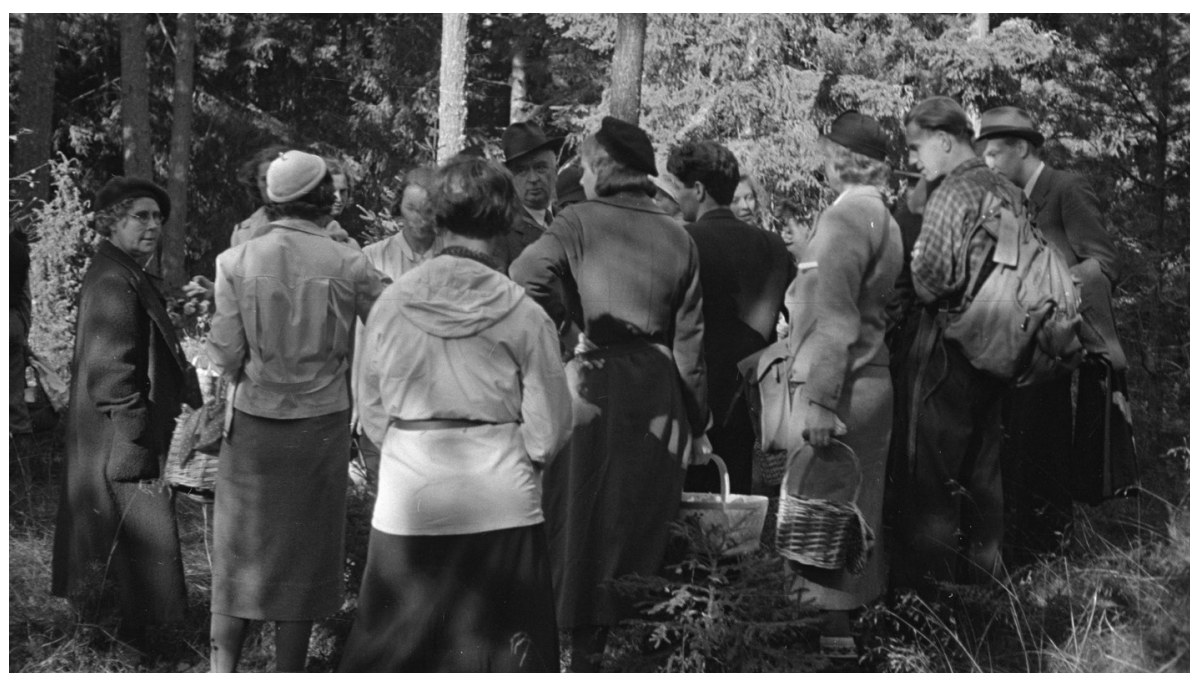

Fig. 9 A group of mushroom pickers gathered in a glade in the forest, with focus on the expert Hugo Stelin standing in the middle. Adelsö, September 25 1938. Photo: Gunnar Lundh (GL.131095). 


\section{Culture Unbound}

Journal of Current Cultural Research

A quick look on the internet indicates that Hugo Stelin was a famous mycologist and the author of several mushroom handbooks and mushroom posters (for example, see Stelin 1936 and 1950). ${ }^{4}$ An article about Stelin shows that he gave lessons, excursions and exhibitions in Stockholm with the aim of teaching people how to use mushrooms for food. Among many other activities, the excursions with the SS Viking are mentioned. Sometimes these popular excursions gathered up to 500 persons, according to the article (Strid 1999). A complete study based on Gunnar Lundh's photo series and the story of Hugo Stelin's work and mission would be an interesting contribution to the history of 1930s health missions and outdoor activities. Perhaps the healthy outdoor life was not the main purpose of this particular outing, but rather the possibility of supplementing the food account during times of crisis. In earlier times, particularly among rural people, mushrooms were not accepted as food, not even in times of famine and poverty. In the 1930s, however, by various forms of education and promotion, mushrooms began to be accepted as food in wider circles (cf. Svanberg \& Lindh 2019).

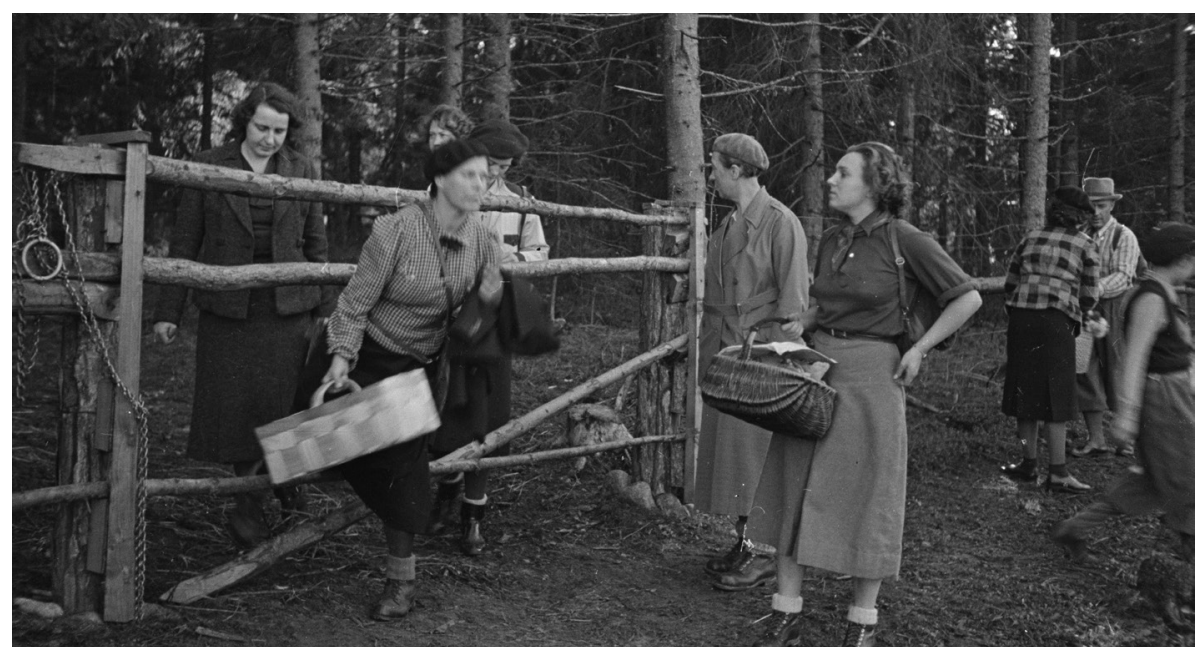

Fig. 10 Dressed in outdoor clothing and with baskets in hand, some of the mushroom pickers are climbing through a fence in the forest. Adelsö, September 251938. Photo: Gunnar Lundh (GL.131127).

The main purpose of publishing these five single photos, from a series of around hundred photos from Adelsö, is to give a visual view of the event. Second, I subjectively picked out photos of good photographic quality. As an additional asset, the identification of Hugo Stelin allowed for a deepening of the story visualised by the photo series. Together with other sources, it is possible to tell something about his role and status in the crowd and it is interesting to note that outdoor life was practised in such large groups. In addition, the cultural-historical 
context of Swedish people's outdoor activities is visualised by the photo series. In the following, I will look at whether the photo series can be further understood by relating them to the Nordic Museum questionnaire responses.
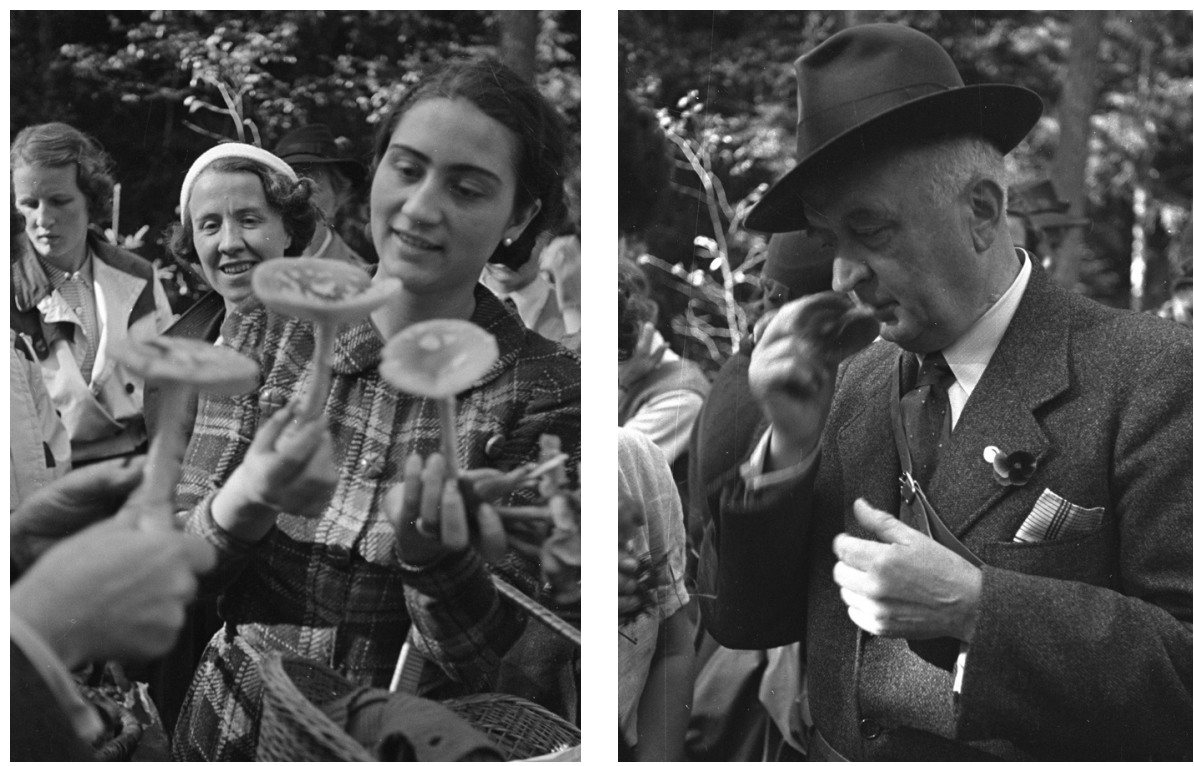

Fig. 11-12 The mycologist Hugo Stelin examines and assesses the fungi. Other photos show that the fungi on the photo to the left are fly agaric (Amanita muscaria). Adelsö, September 25 1938. Photos: Gunnar Lundh (GL.131088, GL.131092).

\section{How to Find Relevant Questionnaire Responses}

For nearly one hundred years (since 1928), the Nordic Museum has delivered recurrent questionnaires to a fixed panel of informants. The museum employees, as well as internal and external researchers, have initiated a number of different themes for the questionnaires. For years, there have been ongoing discussions and problematisation regarding the usefulness of the questionnaire responses as source material (see, for example, Nilsson, Waldetoft \& Westergren 2003). At the same time, there are several research perspectives presented; in this study, I concentrate on the informants' stories rather than on the context of the questionnaire project. Most of the responses, today collected in the museum archive, were transcribed on typewriters in the 1980s. The purpose was to make the archive more available to researchers and to protect the original documents from unnecessary use (Österman 1991). In the 1990s, the transcripts were scanned with digital OCR technology, which made full text searching and page-by-page browsing possible.

Since the questionnaire responses were already digitised, my first idea was to use a number of predetermined keywords to take advantage of the digital possibilities. My purpose was to use the Swedish words for outdoor activities, 
leisure time and holidays, swimming, hiking, biking and camping. It was a good idea, but it did not work. The Swedish word for holidays (semester) failed immediately because it gave an unreasonable number of results. In contrast, the word semesterlag for Annual Leave Act only appeared twice, and in these cases, the informants did not discuss or reflect on the new Annual Leave Act, but, rather, wanted to say something about the 1800 s by referring to the modern concept of "semesterlag" as a contrast to old fashioned living. For instance: "The annual free week was the servants' holiday long before an Annual Leave Act was ever conceived" (Nm 72, EU 24961, my translation).

My searches for keywords in the entire digitised material repeatedly produced too many results. Instead, I went to the analogue archive lists to find questionnaires with topics that seemed to be relevant to the study, such as themes like Midsummer from 1939 (Sp 70), Bathing from 1952 (Nm 159) and Bicycle from 1966 (Sp 212). But it was still difficult to find sources from the 1930s. To begin with, it was not possible to search for keywords within a particular questionnaire; it was only possible to conduct full-text searches of the entire digitised material. Another explanation was that the 1930s had become somewhat invisible when the focus of the questionnaires was changed in the 1960s. Instead of asking older natives about local traditions from times as far back as possible, the questions would now deal with the informants' own experiences. The new direction was connected to society's fast structural change and the current mobility and changeability in the traces of the agricultural society's change into an industrial society. "We want to know what it's like now", Associate Professor Anna-Maja Nylén stated (1961, 1964: 2, cf. Nilsson, Waldetoft \& Westergren 2003). This theoretical reversal led to a time gap. The questionnaires sent out before the 1960s resulted in stories of older times and traditions, while those sent out from the 1960s focus on the contemporary. According to the old structure, the responses to the questionnaires about midsummer, bathing and biking often gazed back to the nineteenth century or the early twentieth century. Even an article based on the bicycle questionnaire from as late as 1966 was exclusively about the emergence of the bicycle in the late nineteenth century (Österman 1967).

Once again, I had to try new directions. By going back to the archive lists, I found Fritiden 1973 (Nm 198) and Semestern (the holidays) from 1978 (Nm 203). The introduction to the questions of Semestern expressed that these two questionnaires were parts of a special project; at the time, the museum had leisure time as a special theme. Referring to the 1938 Annual Leave Act, the informants were asked to recount as much as possible about different holidays during their lives (Nm 203: list of questions). Despite the late date, the informants were asked to write about the past, but now with a focus on their own experiences. This was good news but, unfortunately, I realised that these responses had never been digitised, as they had never been sent for transcription. That was why there 
were no traces of them in the database. As a result, I had to turn to the original documents in the museum archive.

\section{Looking for Traces of Holidays and Outdoor Activities}

The Fritiden 1973 questionnaire generated 182 responses, while Semestern from 1978 generated 225 responses. For this investigation, I have read a selection of the around 200 responses to each questionnaire. Some informants had sent only one or two pages while others supplied lots of pages, in some cases together with photos and drawings. Indeed, it is slow work to read the original documents, written either by hand or on typewriter. On the other hand, the slow reading provides an overview that may otherwise be overlooked when using full text searching based on individual words.

I started with Fritiden 1973, focusing on the responses to the individual question that was specifically concerned with regulated holidays. It soon became apparent that many of the informants belonged to an older generation of farmers. ${ }^{5}$ A lot of them were born in the late nineteenth century and had reached retirement age. The common view was that they had no possibility at all to leave their animals for leisure time or holidays outside the farm. The farmer Harry Olsson in Västergötland (born 1910) described it like this:

For a small farm, holidays is an unknown term, we are three in the family, my wife, her sister and I (all over 60 years old). We have a small farm approx. 13 acres (tunnland) of fields, and 10 acres of woods, and we have 5 cows and around 30 chickens (Nm 198, KU 5161, my translation).

As mentioned before, the large group of farmers (running their own business) were not included by the Annual Leave Act. Still, around 40 per cent of Sweden's population were farmers, and in 1937 around 75 per cent of the farms were smallholders, a group that grew in the 1930s. At the same time, it was becoming clear that most of the traditions surrounding farming would have to stand back in relation to the emerging modern society and increasing number of industrial workers (Hirdman, Björkman \& Lundberg 2012: 54-56). Some informants talked with obvious disdain about such luxury living as leisure time. Others mentioned employers who returned home to their father's farm and women who took care of the home and elderly parents during their paid holidays. Leisure time was not used to rest or take part in outdoor activities; in many cases, the holidays were spent on unpaid home-related work. But there were, of course, many informants who made holiday trips within Sweden, the Nordic region or even in Europe. 
Several mention Norway or Austria. However, among people from different social groups, the most common activity was to spend the holidays on long bicycle rides, with outdoor camping in a tent or staying at a youth hostel. ${ }^{6}$ During the 1930s, the practice of camping and even the word camping was a part of modernity (cf. SAOB 1935: Kamping). Even though the focus on Fritiden 1973 was on the year 1973, the industrial worker Gustaf Svensson from Småland (born 1893) wrote a short flashback:

We got a statutory two weeks of holidays in 1940, just after the war broke out and the borders were closed. Then, the usual bikes came into use. You bought a season ticket at the Swedish Tourist Association and stayed at a hostel for 75 öre per night ... [...] It was easy to travel on the country roads as the cars stood still in the whole country, in the absence of rubber and gasoline (Nm 198, KU 5677, my translation).

The Annual Leave Act was one reason for the great cycling boom of the time. My browsing through Gunnar Lundh's contact sheets shows that the photographer himself cycled and while travelling around on the countryside he used his camera frequently. In July 1937, he visits STF's youth hostel Stocklycke in Omberg in Östergötland (as noted on the contact sheets). Outside the hostel, he photographs two young women - their names are not noted - while they are helping each other with their camping equipment, panniers and suitcases. The number plates S-M
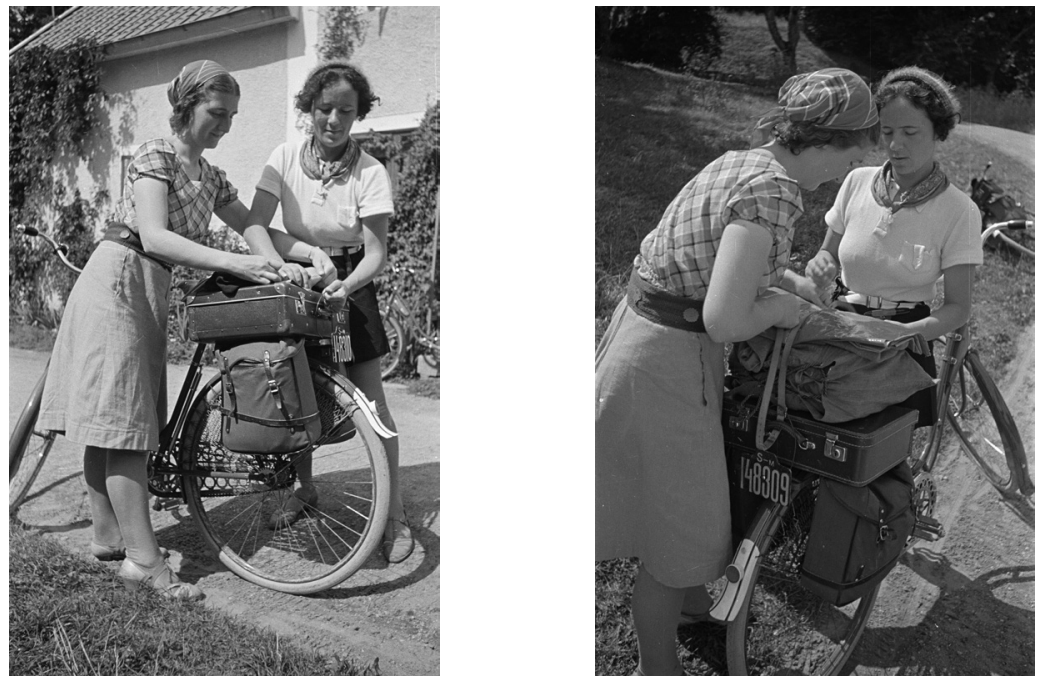

Fig. 13-14 Two young women prepare their pack, dressed in up-to-date clothing for outdoor activities. One woman is wearing a checked blouse, a divided skirt and a kerchief on her head. The other is wearing shorts, a jumper with a collar, a kerchief around her neck and a small cap on her head. Both are wearing long stockings and sandals. Stocklycke, Omberg, July 30 1937. Photos: Gunnar Lundh (GL.123271, GL.123278). 


\section{Culture Unbound}

Journal of Current Cultural Research

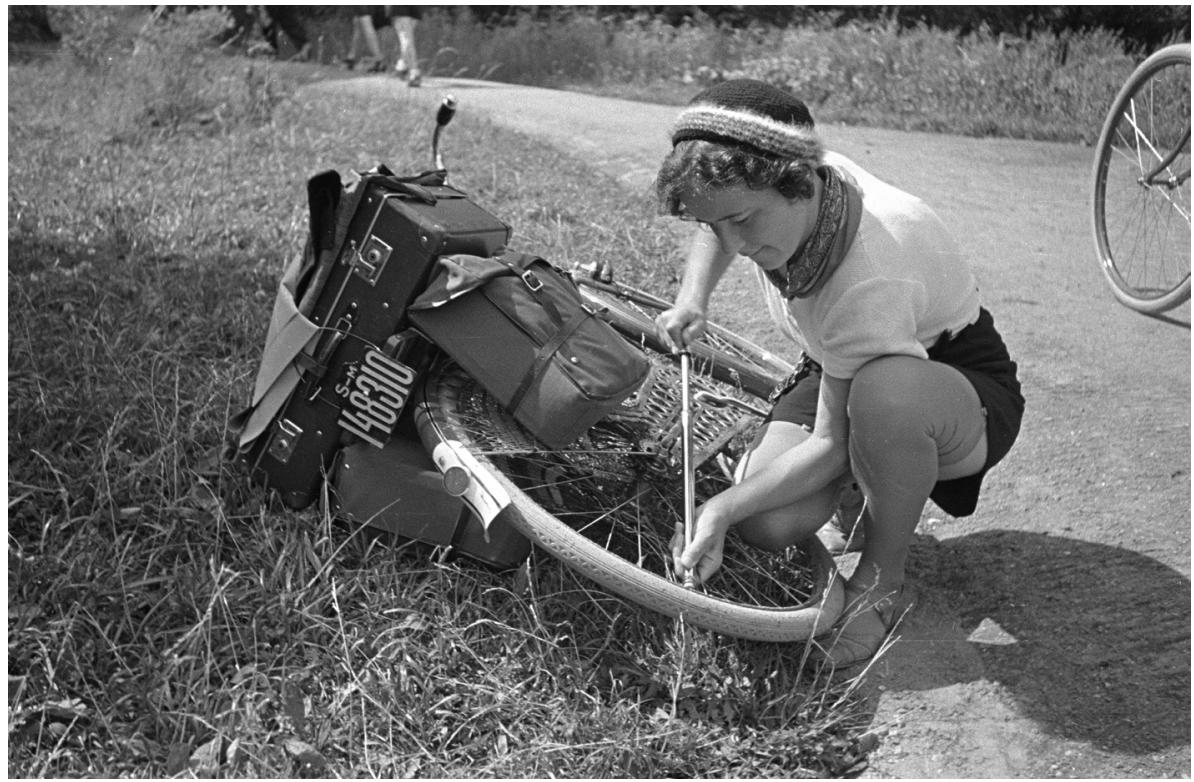

Fig. 15 Before leaving, the woman is pumping her bike. In the 1930s, "Shorts" was a new word in the Swedish language, as well as a new and modern garment. Stocklycke, Omberg, July 30 1937. Photo: Gunnar Lundh (GL.123280).

148309 and S-M 148310 show that their bicycles were registered in Stockholm between 1932 and 1939. In Sweden, the number of bicycles increased from just a few ones sold at the beginning of the 1930s, to one and a half million in use in 1937 (Ekström 2001: 72, 163).

The photo series from Stocklycke and its surroundings contains around 90 black-and-white photos, showing groups of young visitors (men and women) outside the youth hostel as well as their walking tours and boat trips in the neighbourhood. The series, with the published photos as subjectively selected examples, complements the story about 1930s outdoor activities. It supports the questionnaire responses and visualises the representations of a bicycle boom as well as the story of the recently introduced STF youth hostels. But the young people in the photos are unknown, and so is their socioeconomic status. Included in the series are a number of self-portraits of Gunnar Lundh together with some of the young people; maybe he was among friends-it is impossible to know. Anyhow, the series could be a starting point for a discussion of how the welfare state provided for cycling and camping, how STF and the youth hostels were organised and, not least, the image of women's outdoor clothing (which is in line with my own field of research). 


\section{Finding the Most Relevant Results}

In the end, the responses to the questionnaire Semestern, with several stories about different holiday experiences during the informants' lives, turned out to include the most relevant results to my study. The 225 responses, written by hand or on typewriter, are collected in nine archival storage boxes. For this article, I have browsed through four of the boxes to get an impression of the material. I soon found that ironic accounts from farmers about holidays were recurrent. There were also many informants of different ages who described holiday adventures of all kinds. Still, a common comment was that paid holidays was an unknown concept in older times. A few examples show how informants could write about holidays.

Lisa Andersson from Södermanland, married to industrial worker Gunnar Andersson, was around 77 years old when she received the questionnaire Semestern in 1978. Her response includes twelve handwritten pages. Living in a small cottage in the countryside that had belonged to her family for a long time, the moment of writing reminded her that her people had lived there in poverty and that it was a hard struggle for the families and their children. "They had rarely any free time and nobody knew what holidays were", she adds. Nowadays, she was delighted to see the summer guests arriving to the cottages around hers and wished them all the relaxation they could get. Lisa remembers that they spent Gunnar's first paid holidays-one week in the summer of 1939-with her in-laws who lived in the neighbourhood. She points out that her husband's first holiday, when she took time off herself, was the fairest and the best, probably because they never had experienced leisure time together before. She also expresses that she never had any paid holidays herself, as the Annual Leave Act did not include her work with laundry and cleaning for different employers. For Lisa and Gunnar, as for many workers, the enjoyment of paid holidays came to an abrupt end due to the outbreak of the war in September 1939:

Then it took five years before we could have a real holiday again, when the war broke out in the world, it meant that Gunnar was enlisted for long periods, and the few free days he got we spent at home with shorter bicycle trips (Nm 203, KU 7138, my translation).

In contrast to Lisa Andersson's extensive account, another informant, the farmer Carl Andersson from Småland (around 80 years old) sent a response that included no more than eleven handwritten lines. He could not remember anyone at all having talked about anything resembling holidays. As a farmer he had never had leisure time, as it was not possible for him to leave the animals on Friday night and return on Monday morning. Everyone talks about saving money as times are difficult, he added, but when they talk about holidays, they do not seem to miss any money at all (Nm 203, KU 7144). According to the few lines, holidays were 
completely irrelevant to him. With a bit of envy, he snapped at those who actually had some leisure time.

On the pre-printed cover of Carl Andersson's file, the museum curator has noted "Negative response" and under the heading "Fee" there is nothing but a line (whereas the fee for Lisa Andersson was SEK 80). ${ }^{7}$ Remarks like this have not been transferred to the typed questionnaire responses, and the curator's valuation is invisible in the digitised material. In my opinion, this underlines the reason (among others) why researchers should comply with the request on the covers of the typewritten questionnaires: that in the event of publication, it is necessary to compare with the original document.

My very first reaction was that the questionnaire responses would be useless for this study as the dominating group of farmers did not have any leisure time at all. But even though the selected references above relate to the concept of holidays, I presume that the nine storage boxes containing the Semestern responses would give some individual stories about holidays and outdoor activities in the 1930s. And it could probably be productive to complete the study with full text searching in the digitised questionnaire material. But in both cases, it would maybe be like looking for a needle in a haystack, as the material is of such large dimensions and as the questionnaires are created in a foreign context. In addition, if the general purpose is to study the materiality of individual responses, sometimes with photos or drawings, the original documents are essential. Consequently, it is fruitful to approach both the digitised transcriptions and the original documents (cf. Dahlgren 2009).

\section{The Ideas of the Leisure Time Reports}

As mentioned above, my first impression was that the questionnaire material was almost useless when it came to analysing modern 1930s thoughts about holidays and recreation. The retired farmers had never had leisure time at all as they could not leave the animals even for a few days, and certainly not any paid holidays, as the Annual Leave Act did not include them. In contrast, the young people, as seen in Gunnar Lundh's outdoor scenes, seem free and relaxed when they enjoy nature, sunshine and fresh air. I argue that the Government Official Report on leisure time, Fritidsutredningen (SOU 1940:12), acts as a connection between the farmers and the outdoor people. The Annual Leave Act report (SOU 1937:49) was published a few years before the leisure time report, but both projects were carried out during the same period, and they contain cross-references. Both were about the opportunity for the landless population to enjoy nature tourism and outdoor activities; both were intended to promote outdoor life.

The main issue for Fritidsutredningen was to investigate the establishment of recreation reserves for the residents of heavily populated communities (SOU 1940:12). The report clarifies that the whole idea of holidays and outdoor life 
emerged from the welfare project's desire to draw the landless population out into the fresh air. It was primarily workers, often immigrants from rural areas, who more or less voluntarily ended up at the enclosed urban workplaces. A parliamentary bill emphasised that everyone should agree that outdoor life in the woods and fields was the best counterweight to the stresses of the hard-working life (SOU 1940:12: 16). According to the Medicinal Agency, the general pursuit of being in the open air should be facilitated by all available means (SOU 1940:12: 27). All respondents agreed that outdoor recreation was wholesome and necessary for the landless population who sat still at their workplaces all day. A significant part of the report dealt with the question of which fields and areas would be used for the promotion of outdoor life. It was about rules for using certain land areas and even about opportunities for expropriating land in favour of outdoor life, if the land was essential for the general public or for the population in a specific place.

But at the same time as outdoor activities became a popular movement, in line with the ideals of the time, the widespread outdoor activities brought great difficulties, worth evaluating and discussing in the context of the 289 pages of Fritidsutredningen. The problematic background was that between 20,000 and 30,000 Stockholm inhabitants went out in the woods every Sunday. Thus, the urban population's access to the surrounding landscape was a delicate question. It was pointed out that the agricultural and forestry population should, as far as possible, be spared from disturbances by the public on weekends, which could be caused by inconsiderate hikers (SOU 1940:12: 14-18). The main problem was that outdoor activities had become a mass movement that destroyed the ground, because so many people were walking in the woods and the fields. It was a problem that some destroyed and littered while others invaded private property and grounds. This caused conflict with the landowners, such as farmers living near the cities.

The purpose of Fritidsutredningen was to facilitate and look for opportunities for the landless population to engage in outdoor activities, while taking into account the interests of both the farmers and the rural population (SOU 1940:12: 22). Here it is interesting to recall the story about Hugo Stelin and his groups of 500 people that would visit the forest all at once. In this purpose, there is a clear connection between the farmers as landowners, other informants in the questionnaire responses, and the outdoor people depicted in Gunnar Lundh's photographs.

\section{Visual Traces of Modernity}

In autumn 1937, Gunnar Lundh moved to Döbelnsgatan in Stockholm near the swimming facility Vanadisbadet that was under construction at the time. Vanadisbadet is well documented in several of Lundh's photo series, both in colour and black-and-white. Before the official opening in May 1938, he documented 
how the super-modern swimming pool was filled with water, and on the opening day of 15 May, he was there with his camera among the more than one thousand guests. Being the first heated outdoor swimming pool in Stockholm, Vanadisbadet was a unique attraction at a time when Stockholm municipality planned to build swimming facilities in every district-indoors or outdoors, swimming pool or beach -in line with 1930s hygienic and social ambitions. Behind the proposal was Councillor Oscar Larsson, who opened Vanadisbadet in its new, extremely modern building, announcing his motto "Go swimming!" (Svenska Dagbladet, 16 May 1938).
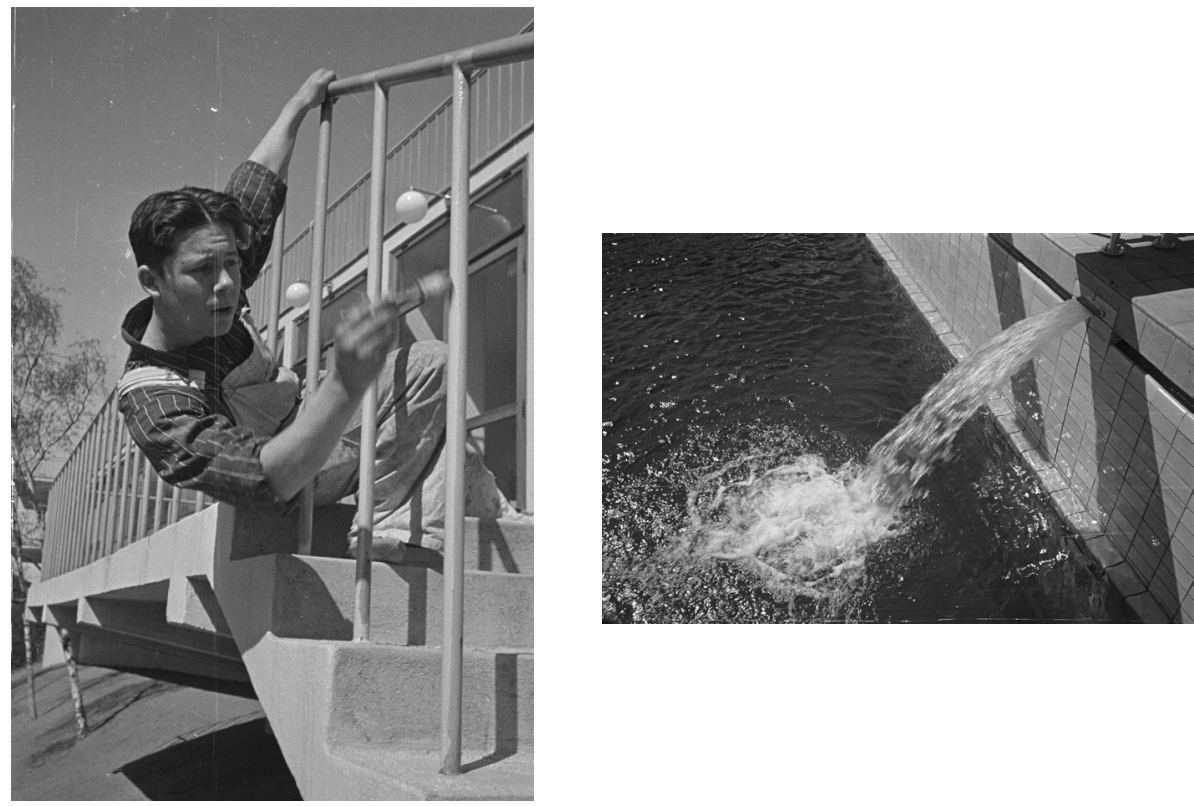

Fig. 16-17 Painting of the banisters outside the entrance to Vanadisbadet; the swimming pool fills with water before the opening day on 15 May 1938. Photo: Gunnar Lundh (GL.128802, GL.128808).

It is interesting to look at Vanadisbadet as it shows how the Annual Leave Act and the leisure time report were implemented in a local, urban political context. Built in high-fashion Swedish "funkis" style, Vanadisbadet provides an insight into the society's view of the importance of health and outdoor life. The unique heated swimming pool was the culmination of the municipality's ambitions to establish bathing facilities in each district. Acting as a news reporter, Gunnar Lundh documented the opening of Vanadisbadet, while as a documentary photographer, he took lots of photos during his obviously frequent visits to the nearby swimming pool. ${ }^{8}$ 

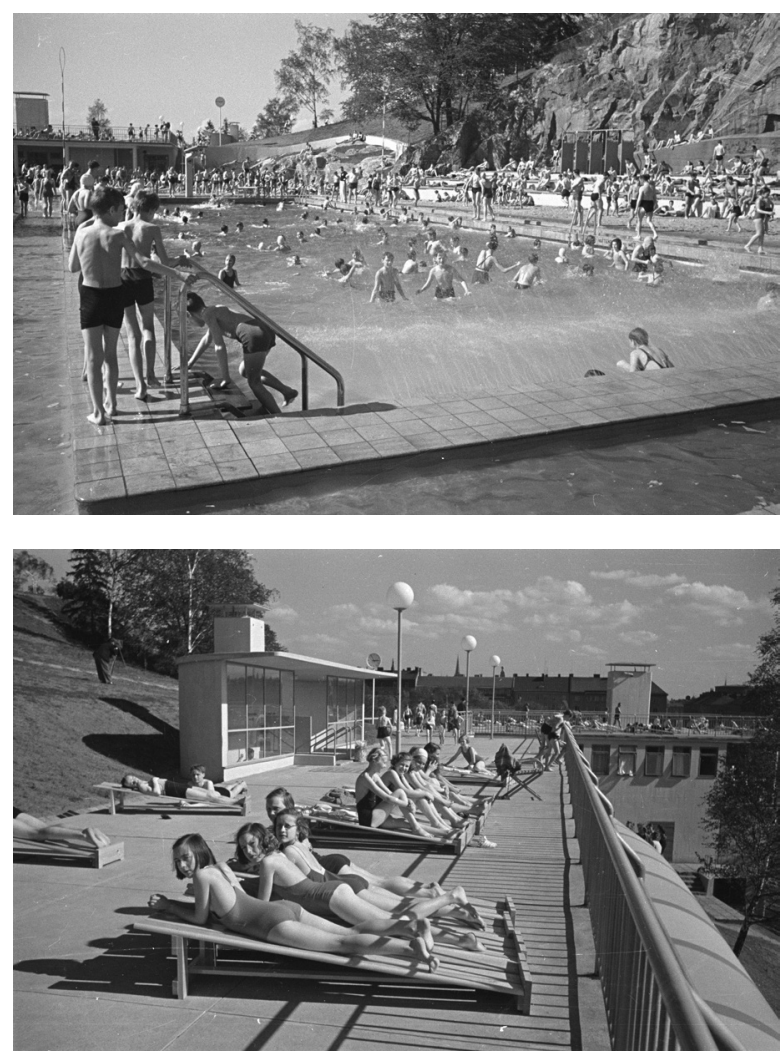

Fig. 18-19 Vanadisbadet, with children playing in the water streams at the end of the pool. Behind the pool; part of the modern funkis building with a café inside and an area for sunbathing on the roof. Vanadisbadet, Stockholm, 17 May 1938. Photos: Gunnar Lundh (GL.129072, GL.129085).

In this article, the digitised archive of the daily newspaper Svenska Dagbladet has been a fruitful way to acquire knowledge about the construction and opening of Vanadisbadet. Again, a bricolage of sources completes the discourse about health and outdoor life in the 1930s. But we still do not know anything about the people depicted. Maybe Lundh was more interested in the image of the modern society than in the individuals he photographed (cf. Strandroth 2007).

\section{Conclusions}

The combination of sources used in this article supports that in the 1930s health project, holidays and outdoor life were part of urban people's lives, while for rural people this was not easily combined with the conditions of agriculture. These results are reflected in the museum's source material as well as in the official government reports, earlier studies and historical sources. In the study, I have used an imaginative mixture of various kinds of sources, according to a method sometimes referred to as bricolage (cf. Jönsson \& Nilsson 2017). 
As the photographs and the questionnaire responses are collections of huge dimensions, they contain a wealth of information, which means that research takes time. In different ways, both express representations of people's everyday lives, even though the people depicted in the photos and their socioeconomic backgrounds are unknown. On the topic of this study, there is a problem that the group of informants consisted predominately of rural people while the impression of the photos is that they mainly depict urban people's interests and habits. Even though there is a gap between the photos and the informants' responses, another, deeper study could possibly help broaden the image of outdoor activities in people's everyday lives in the 1930s. The bricolage method points out that the combination of sources broadens the image of different groups' relationships to outdoor life.

I have described my browsing through the hundreds of contact sheets as looking at a film, but without the names of the actors. Even though the knowledge of the mycologist Hugo Stelin makes the film more interesting, it is my opinion that the series of photos visualise events that broaden the image of 1930s outdoor life. A single photo can be the basis for different interpretations; it can tell us much or it can be quite anonymous. The contact sheets, with their series of photos, have been essential insofar that they have added knowledge beyond the individual photos. While studying the photos and the questionnaire responses, it is enriching to explore both the functional archive context, the physical materiality of the documents and the content of the stories expressed by photos and informants, including relevant evaluation of the sources.

The digitising of the photographs and the questionnaire responses has made the collections searchable and available in a positive way. However, the fact that the responses to "my" questionnaires had been omitted made me think of how the result is affected by whether the material is digitised or not. Reading the original documents is rather different from searching for keywords in the database. It is constructive to look at the original documents as well as searching in the database, when possible. Digitisation opens new search options on various themes, but the accessibility depends entirely on which material is entered into the database and how it is documented and tagged. Within the VBB project, we have realised that the work of entering new information into the database is extremely time consuming.

Marianne Larsson holds a PhD in ethnology from Stockholm University. She is currently a curator at The Nordic Museum in Stockholm. Her main research area is related to outdoor life and casual clothing. Her doctoral thesis is about Post Office uniforms and the interaction between texts, images and objects. She participates in the research project Images and Stories of Everyday Life. E-mail: marianne.larsson@nordiskamuseet.se 


\section{Notes}

1 Today Svensk Form/Swedish Design.

2 He likely knew about the ongoing photo documentary FSA project in the USA with its purpose to improve the situation of the poorest farmers in the American countryside (see Strandroth 2007).

3 The name "Siv Smith" is also noted, but she is still unknown.

4 For a view of the mushroom poster (Stelin 1950), see NM.0322229 in the Nordic Museum's collections.

5 For information about the composition of the groups of informants, see Österman 1991: 64-75. The author confirms that the group was dominated by farmers, although many other professions were represented.

6 The introduction of the Swedish Tourist Association's youth hostels is described in Eskilsson 2008.

7 Österman points out that only modest fees were rewarded (1991: 13).

8 Gunnar Lundh also documented other modern swimming facilities in and around Stockholm.

\section{References}

\section{Unprinted sources}

\section{The Nordic Museum}

Aftonbladets svampkarta (Stelin 1950), NM.0322229. https://digitaltmuseum.se/ owners/S-NM.

Gunnar Lundh's archive (1961/063).

Nylén, Anna-Maja (1961). "Traditionsuppteckningar och nutid", Meddelanden från Etnologiska undersökningen, 86.

Nylén, Anna-Maja (1964). ’Om 'man' och strukturförändringen”, Meddelanden från Etnologiska undersökningen, 89.

Questionnaire responses

Nm 72, Kalendern och dess märkesdagar (1943).

Nm 159, Bad (1952).

Nm 198, Fritiden 1973 (1973).

Nm 203, Semestern (1978)

Sp 70, Midsommar (1939).

Sp 212, Cykeln (1966).

\section{Others}

Svenska Dagbladets historiska arkiv: https://www.svd.se/arkiv

SAOB, 1935: Kamping, https://svenska.se/saob/?id=K 0233-0113.ZYNm\&pz=7, taken 2018-08-16. 


\section{Culture Unbound}

Journal of Current Cultural Research

\section{Literature}

Dahlgren, Anna (2009): "Tankar om tillgänglighet och fotografier i arkiv", Anna Dahlgren \& Pelle Snickars (eds): I bildarkivet: Om fotografi och digitaliseringens effekter, Stockholm: Kungliga biblioteket, 59-89.

Ekström, Gert (2001): Älskade cykel: År 1800-2000, Stockholm: Prisma.

Eskilsson, Lena (1995): "Fritiden: om fritidens idé och en utställning i Ystad 1936", Tvärsnitt: Humanistisk och samhällsvetenskaplig forskning, Stockholm: Humanistisk-samhällsvetenskapliga forskningsrådet (HSFR), 1995:4, 16-29.

Eskilsson, Lena (2008): "Friluftsliv", Jakob Christensson (ed.): Signums svenska kulturhistoria: Det moderna genombrottet, Stockholm: Signum, 362-391.

Franklin, Stuart (2016): Documentary Impulse, Phaidon Press Ltd.

Frykman, Jonas (1992): "In Motion: Body and Modernity in Sweden between the World Wars", Ethnologia Scandinavica, 36-51.

Hirdman, Yvonne, Jenny Björkman \& Urban Lundberg (2012): Sveriges historia 1920-1965, Stockholm: Norstedt.

Jönsson, Lars-Eric \& Fredrik Nilsson (eds) (2017): Kulturhistoria: En etnologisk metodbok, Lund: Lunds universitet.

Larsson, Marianne (2011): Män i baddräkt: En kroppslig kulturhistoria, Stockholm: Nordiska museet.

Larsson, Marianne (2014): "Class and Gender in a Museum Collection: Female Skiwear", Marie Riegels Melchior \& Birgitta Svensson (eds): Fashion and Museums: Theory and Practice, London/New York: Bloomsbury, 91-107.

Lyngø, Inger Johanne (ed.) (1993): På vandring: En tur i friluftslivets historie, Den Norske Turistforening 125 år (exhibition catalogue). Oslo: Norsk Folkemuseum.

Modern Leisure: A Swedish Exhibition, June 19-Aug. 23, 1936(1936), Ystad exhibition in cooperation with The Swedish Traffic Association (exhibition catalogue).

Nilsson, Bo G., Dan Waldetoft \& Christina Westergren (eds) (2003): Frågelist och berättarglädje: Om frågelistor som forskningsmetod och folklig genre, Stockholm: Nordiska museet.

Pihl Atmer, Ann Katrin (1998): Livet som leves där måste smaka vildmark: Sportstugor och friluftsliv 1900-1945. Stockholm: Stockholmia

Ranby, Caroline (2013): Kongl. hoffotograf Peter P. Lundh: Det bästa ljus och nutidens bästa instrumenter. Höganäs: Höganäs museum \& Höganäs bokhandel \& förlag.

Sandell, Klas \& Sverker Sörlin (eds) (2008): Friluftshistoria: Från "härdande friluftslif" till ekoturism och miljöpedagogik: teman i det svenska friluftslivets historia, Stockholm: Carlsson.

Svanberg, Ingvar \& Hanna Lindh (2019): "Mushroom hunting and consumption in twenty-first century post-industrial Sweden", Journal of Ethnobiology and Ethnomedicine, 15:42, 1-23.

SOU 1937:49: 1936 års semestersakkunniga: Betänkande med förslag till lag om semester.

SOU 1940:12: Fritidsutredningen: Betänkande med utredning och förslag angående inrättande av fritidsreservat för städernas och de tättbebyggda samhällenas befolkning.

Stelin, Hugo (1936): Aftonbladets och Nordiska kompaniets svampbok, Stockholm: Nordiska kompaniet.

Stelin, Hugo (1950): Aftonbladets svampkarta - svampbok, Stockholm: Aftonbladet.

Strandroth, Cecilia (2007): In Search of the Pure Photograph: A Historiographic Study of the Farm Security Administration, Walker Evans, and the Survey Histories of Photography, doctoral dissertation, Uppsala university.

Strid, Åke (1999): "Hugo Stelin-en av stockholmsmykologerna: 2. Utåtriktad verksamhet och samarbetet med Aftonbladet.", Jordstjärnan: medlemsskrift för Sveriges Mykologiska förening, 20:1, 20-36. 
Svenska Dagbladets Årsbok 1936, Stockholm: Svenska Dagbladet, 76-77.

Söderberg, Rolf \& Pär Rittsel (1983): Den svenska fotografins historia: 1840-1940, Stockholm: Bonnier fakta.

Österman, Annika (1967): "När cykeln kom till byn”, Nordiska museets och Skansens årsbok 1967, 166-170.

Österman, Annika (1991): Människors egen historia: Om Nordiska museets frågelistverksamhet, Stockholm: Nordiska museet. 


\title{
From Excerpt to Cosplay. Paths of Knowledge in the Nordic Museum Archive
}

\begin{abstract}
By
Simon Ekström

Abstract

The aim of this article is to shed some light on the situation that occurs when scholarly knowledge, once highly valued, is successively undermined, while elements of the same learning live on as attractive resources to other stakeholders. More accurately, the research question relates to the process that starts with many ethnologists who, over time, come to increasingly view formerly important materials as less relevant to their own academic issues. For the sake of the argument, the Nordic Museum's extensive collection of excerpts concerning folk customs and beliefs is used as an eye-opening case study. During the 1960s and 1970s, folklore researchers and ethnologists retreated from researching those lingering traces of the past-of which the Nordic Museum's excerpt collection constitutes a powerful material centre-and thus this field was left free for others to claim. By drawing attention to both the productive force of the Nordic Museum's collection of excerpts, and a number of contemporary and popular representations of ancient folklore, this article actualises a set of questions that deal with the relationship between new and old knowledge; for what becomes of previously sought after academic learning, once treasured in the Nordic Museum Archive, when the vast majority of the discipline heads for new materials, methods and theories?
\end{abstract}

Keywords: Archive, Excerpts, History of knowledge, Remediation, Nordic museum.

Ekström, Simon: "From Excerpt to Cosplay. Paths of Knowledge in the Nordic Museum Archive", Culture Unbound, Volume 12, issue 1, 2020: 116-140. Published by Linköping University Electronic Press: http://www.cultureunbound.ep.liu.se 


\section{Introduction: How to Become a Mermaid}

Just before Halloween 2016, the popular Swedish vlogger Therese Lindgren posted five videos on YouTube in one week, centring on the theme of Nordic Creatures. Described as tutorials, she outlines in detail how she dresses up as a mermaid, a forest nymph, a troll, a myling, and a tree sprite. However, these videos contain more than practical advice on foundation creams, eyeliner and hair gel. Each make-up session either begins or ends with Lindgren acting out the completed character on camera in a suitable natural setting. At the same time the forest nymph or troll is presented to the viewer, Lindgren's voice can be heard in the background as she, with great seriousness, explains some of the beliefs surrounding the creature in question.

At the beginning of the first video, in which Lindgren makes herself up into what she presents as a "seductive mermaid", the camera sweeps across a pile of books lit only by flickering candle light. One of the volumes is open to reveal a handwritten page. This is followed by Lindgren's suggestive characterisation. ${ }^{1}$ In translation, as the presentation is in Swedish, it goes like:

The Nordic mermaid is a powerful creature who rules over the water, the wind and the creatures of the sea. She can take on different forms, although most commonly she appears as a beautiful woman with long, flowing hair, which she can be seen sitting and combing at high tide. She normally demonstrates some fish-like features, such as gills, scales or a fish tail instead of legs. Handsome sailors run the risk of being lured down into the ocean by the mermaid, where they will live with her. However, those who refuse to heed the mermaid's call will feel her power and may find themselves aboard a sinking ship bound for the ocean floor.

Of course, one may well question how these tutorials should be viewed: Are they lingering folkloric relics in a digital age? Or are they a game of transitory identities in which Lindgren creatively borrows and combines elements from an older repertoire? Both questions are legitimate from an analytical perspective, but here I will test another point of entry. The intention of this article is to describe the dual movement whereby gathered knowledge is subjected to a critical process where scholarly value is successively undermined and downgraded while elements of the same learning live on as attractive resources in relation to both old and new stakeholders. Put differently, it is a matter of identifying the connections that join together the modern vlogger's YouTube performances with folklore research/ ethnology and the Nordic Museum as historically situated knowledge producers. 
As we will see, the search for the roots of these pedagogical videos leads us to the museum's bottom floor. It is here, in the section of the museum that includes the archive expedition, the library and the public reading room, that the extensive excerpt collection of folk beliefs and customs is stored. The collection is part of a larger corpus of material that constitutes the museum's Folklore Collection. The name is the result of a previous classification in which folklore researchers in the beginning of the twentieth century made a clear division between spiritual and material culture. Belief, custom and legend, like the fairy tales, were then attributed to so-called folklore. Other similar collections and archives were created in Sweden at the same time, most notably in Lund (1913), Uppsala (1914), and Gothenburg (1919).

The Nordic Museum's collection of excerpts contains large amounts of the past century's accumulated knowledge of the imaginative world that accommodated beings like water sprites, ghosts, gnomes, trolls and mermaids. Although knowledge always tends to change as it moves between different actors and media (cf. Bolter \& Grusin 1999), it is possible to establish a linkage between the already described stagings of various Nordic folklore characters on the digital platform of YouTube, and the considerably older excerpt collection. However, in doing so, we will also have to consider the fact that the majority of today's ethnologists and folklorists seldom make use of the original learning or forms of knowledge represented by the excerpts at the museum. By taking contemporary, non-academic, interpretations of old folklore as a point of departure, like the already mentioned performance on YouTube by Swedish vlogger Therese Lindgren, it becomes possible to relate these matters to a set of questions that deal with the relationship between new and old knowledge; for what becomes of previously accepted learning when the very scholarly point of it has migrated elsewhere? What possible lines of retreat and alternatives remain open to this older knowledge? And which new stakeholders will take over the stage that others, for various reasons, have left vacant?

\section{The Study of the Lingering}

Excerpt collections of various kinds have been created and stored in a wide range of archives. There is consequently considerable variation in how they are used as resources for both research and knowledge building. Therefore, before going any further with the subject, I would like to emphasize that the collection on which this article focuses is that which is associated with the Nordic Museum's Folklore Collection. Even though the article's discussion first and foremost applies to excerpts from the Folklore Collection, it might be of interest that the Nordic Museum's archive also keeps other excerpt collections that cover the presence of various material cultural products such as harrows, pepper mills or women's 
aprons. ${ }^{2}$ Needless to say, internationally, the use of excerpts has played a decisive role in many knowledge institutions (see Krajewski 2011).

The excerpts in the museum's Folklore Collection take up several cubic metres of space in the Nordic Museum's combined library and reading room. Overall, they can be described as isolated notes on some specific aspect of the themes of folk belief and custom that earlier museum staff and scholars have considered of interest at the time they were collected or sorted. In other words, these are saved excisions from larger wholes. The main habitats of the excerpts in question, what one might call their primary or original environments, were the theoretical schools of evolutionism and diffusionism, the former with roots in Romanticism and late nineteenth-century religious studies, the latter in the German theory of culture areas. In these settings the standpoints of the individual observation of folklore, whether still living or preserved in human memory, were made a perfect match with the greater theoretical context. When it comes to folk beliefs, this was expressed most clearly in what was known as the historical-cartographic method (or the Finnish school), in which the map was filled with dots that showed how a certain spiritual artefact manifested itself in geographical reality. ${ }^{3}$ For some decades, the dominant evolutionistic research interest steered towards seeking to reconstruct the most ancient types of myths, folk tales or customs and use, from which later variants had somehow departed. It was also deemed important to clarify cultural boundaries, pathways of dissemination and various types of relic-free areas, as well as the existence of survivals that had somehow resisted the work of time. Accordingly, those later tools and ambitions were the theoretical stands that all together constituted the diffusionistic program. ${ }^{4}$

In the introduction to Bygd och yttervärld (1942), Sigfrid Svensson, however, proposes a somewhat different method of approaching this old problem. He instead wants to know what happens when the novelty (in the form of innovation) comes to the countryside. How, as Svensson puts forward the question, does the new spread? How is it greeted and through which stakeholders and influencers is it assimilated? At the same time, in his own investigations, Svensson is actually just as interested in what causes resistance to the new, and the question of how and why the old is left behind. The studies in the book therefore deal with cultural meetings in which different layers of time stand against one another. For a period, whether long or brief, these periods coexist-sometimes resulting in combinations or hybrids-until the new finally gains the upper hand.

The discussion I intend to pursue is reminiscent of Svensson's initial question. I, too, am interested in change, disappearance and lingering as expressions of processes that may be viewed as both drawn-out and complex. However, the studies in Bygd och yttervärld are always based on what happens when something 
new appears on the scene-i.e. how novelties and innovations are received and disseminated or, on the contrary, discarded-while I primarily want to consider how the old continues to linger on. Transposed to the excerpts at the Nordic Museum, this means an interest in what happens as, over time, many ethnologists come to increasingly view these items as more or less irrelevant for their own academic issues.

The forthcoming discussion is then in theoretical debt to the interdisciplinary and constantly growing field of history of knowledge. It is common in these studies to highlight how older forms of knowledge are hybridised and associate themselves with other groups and interests (Secord 2004; Burke 2016; Östling \& Heidenblad 2017; see also Bäckman in this issue). This means that even established media, through which the previously recognised academic knowledge was preserved and communicated (e.g. literature, archives, excerpts, tables, maps, exhibitions and lectures), may be supplanted by or coexist with other, more disparate, forms of media (e.g. scholarly writing for a non-academic public, young adult fiction, and other fictional literature, as well as films, video games, live action role-playing, and cosplay). When knowledge is circulated between various stakeholders and audiences in this way, it is normally also re-mediated between genres and modes of presentations (Åhrén 2004; Gustavsson 2012; Gustavsson 2014:179ff; Jülich 2015; Östling 2015). In fact, in the process, it is not uncommon that words take the shape of a different kind of materiality.

The enormous impact that different forms of intertwined media nowadays have on society is effectively captured in the concept of mediatization (see Lundby 2009, Hjarvard 2013). Another line of inquiry, perhaps with still greater relevance for this particular article, is the idea of the folklorescue as an ongoing intertextual relation, characterised by both strategic creativity and fuzzy allusions, that is taking place between folklore and popular culture (Foster \& Talbot 2016).

\section{The Excerpt Collection at the Nordic Museum}

The museum's excerpt collection consists of anything between five hundred thousand and one million catalogue cards (af Klintberg 2010b:214; Gustavsson \& Palmenfelt 2017:410) sorted under carefully specified headings and collected in two separate card catalogues. These are the topographic and subject-oriented (or more correctly: keyword-oriented) collections. As each individual card in the two collections contains data on both the actual folklore substance as well as the geographic domicile (parish), the collections are constructed so as to constantly refer to each other. Thus, the museum is in possession of two complete sets of transcripts of highly sought after material from collections, records and overviews of folk memory relating to customs and beliefs. With reference to the tutorials on 
YouTube, by vlogger Therese Lindgren, we can pick a card from the collection that recapitulate a meeting with the Sea Queen:

Bohus County Tegneby Parish V. 429:8

One morning, a man who lived at the far end of Tånge Sound-I don't know if it was on Lyr Island or on the Mollösund side-went fishing. The weather was intensely beautiful. Then he caught sight of a lovely lass sitting beside the water combing her hair. Her long hair shone like gold. As he rowed close to take a better look at her, she disappeared. Just then, the weather took such a turn for the worse that he was forced to head for land. It was the Sea Queen.

C-M Bergstrand: Gammalt från Orust (Old Tales from Orust), 1962, p 13. Disc. Karl Johansson 1920, Torp, Tegneby. Translated excerpt, Nordic Museum Folklore Collection.

This is knowledge that was once considered so important that great pains were taken to collect and preserve it for posterity. The desire to search through regions and landscapes for the surviving evidence of ancient beliefs has given rise to expeditions all over the nation, influenced the dispatched researchers' choice of questions and formed the basis for large numbers of scholarly publications (cf. Nylund Skog's article in this issue). Therefore, the topographic and subject-oriented collections are at once the result of and incentive to a certain kind of knowledge primarily about preindustrial society. In this sense, the excerpts have contributed to the creation and maintenance of both academic and museological careers. Before going any further with these kinds of conclusions, there is, however, reason to highlight some basic features of the collection's genesis and lines of origin. Namely, that means first presenting the historical setting of the collection, and secondly introducing the museum's use of so-called questionnaires.

The history of the two-part excerpt collection at the Nordic Museum extends back to the early twentieth century. However, even earlier chroniclers such as Gunnar Olof Hyltén-Cavallius and Per Arvid Säfve were already creating private collections of their own and others' fairy tales, customs and colloquialisms (see, for example, Gustavsson \& Palmenfelt 2017). It should also be noted that, at the end of the nineteenth century, the founder of the Nordic Museum, Artur Hazelius, had himself purchased an early collection of excerpts known as the Wallman Collection. In 1907, Nils Edvard Hammarstedt was appointed as the first director of the Archive for Swedish Folk Beliefs and Customs (from 1917 onwards, reconstituted as the Archive for Swedish Folk Knowledge) at the Nordic Museum. Today, the name Folklore Archive is used. The ambition to build a national central folklore archive was largely Hammarstedt's. On his retirement in 1930, the excerpt 
collection included some 30000 items. However, with the establishment of the Hammarstedt Archive at the Nordic Museum, the organisation's conditions were changed at a stroke.

The idea, introduced by Hammarstedt and followed up by his successors, was as simple as it was effective, and it all comes down to disintegration, systematisation, and reintegration. A thorough review of the older collections and sources made it possible to isolate individual motifs from the records, which could then be recorded on separate cards that were sorted into a single gigantic catalogue. Keywords on catalogue cards could then be successively supplemented with new transcribed notes from previous records and research expeditions. For obvious reasons, it was a time-consuming task. By the mid-twentieth century, Carl-Herman Tillhagen, a later director of the Nordic Museum's Folklore Collection, had succeeded in obtaining public funds for a complete review of the archive's handwritten folkloric material relating to folk poetry, beliefs and customs. As many as 20 project workers, many of them Baltic refugees from the Second World War, were then kept busy for several decades with the enormous task of completing the excerpt collection. It was also Tillhagen who introduced the previously mentioned dual cataloguing of the folkloric material into a subject archive (or keyword register) and an equivalent topographic archive (af Klintberg 2010b).

Historical overviews of research often underline how, during the first half of the twentieth century, the discipline of Swedish ethnology (previously folk life studies) grew from an intimate collaboration with the Nordic Museum (see, for example, Hellspong 1993; Nilsson 1996, 2004; Gustavsson 2014). Even up until the publication of Åke Daun's licentiate thesis Upp till kamp i Båtskärnäs in 1969, the museum had been, together with the institutes of folklore in Lund, Gothenburg and Uppsala, a disciplinary hub for major research projects, as folklorists and folk life researchers took on the gigantic task of collecting and documenting the consequences of modernity for rapidly declining rural communities (cf. Lilja 1996; Löfgren 1996; Nilsson 2004; Skott 2008). Throughout this period, questionnaires were an important tool for the museum's staff as a method for collecting, following up and charting. They have continued to be so, even if with a view to obtain different knowledge.

That questionnaires have been so crucial to vital parts of the Nordic Museum's knowledge production for such a long period of time means that they have been the subject of a large number of intradisciplinary studies and surveys. We therefore have a fairly good idea of the process by which the material was gathered: by a paid staff of local informants to whom were sent lists of questions and topics that the museum wanted to know more about. Those "local informants" were 
ordinary people who occupied a position with a certain cultural capital within the community. Their task was to make enquiries regarding conditions in earlier times by contacting those in the community with reliable memories. The answers to the predetermined questions were then sent back to the museum, where they were transformed into academic descriptions, reports and conclusions.

This included hard work by the museum staff as reports submitted by the informants from their own local area were combed over to uncover individual assertions regarding forest nymphs, mermaids, mylings and whatever else might emerge. However, as stated previously, the questionnaires were not the only source of submissions for the museum's excerpt collection. It was the already established working method with regard to excerpts that was transferred to the questionnaires when they were first used at the museum in 1928. Consequently, the catalogue cards in the museum bear witness to a parallel (and in some cases considerably older) collection, consisting of notes by museum staff relating to general proof of whatever phenomena those representatives of the then frontline of research considered important to document. To a large extent, these could be categorised as belief and custom, which earlier folklore researchers-who were rooted in nineteenth-century Romantic language and dialect research-perceived as being closely related to antique and prehistoric belief systems and preserved in the national folk spirit (cf. Nilsson 1996; Salomonsson 2003, Engman 2015). In this cumulative research paradigm, where layer was piled upon layer, any additional data and observations were welcomed as an increase to the already collected mass. The scrutiny was, in search of usable information, extended to previous collections, newspapers, printed tales and publications by other researchers and other donated excerpt collections. These items were incorporated into the museum's ever-expanding knowledge bank in the form of additional catalogue cards. The task of the excerpts, the motivation for their very existence and justification for this extensive writing process, was to render already collected material accessible for diverse academic purposes.

The early 1960s saw a departure in the design and use of questionnaires (cf. Larsson's article in this issue). Local informants and specific respondents were no longer sought out by the museum. The intermediary disappeared in favour of stories taken directly from people's own experiences. This is a well-known shift in focus and method, carefully described in the literature (see Nilsson 2003; Salomonsson 2003, Westergren 2003, cf. Lilja 2016). Less consideration has been given to the part of the process in which the individual answers on each questionnaire were copied down, cut into smaller parts, sorted under the double entries of subject and parish, and saved as excerpts in the museum's collection. Although the lack of wider context that arose regarding these fragments of the original responses has been addressed, the issue of how these rewritten and 
isolated notes were actually used and utilised in the existing research environment has mostly flown beneath the radar (however, see Frykman 1988, Klein 2003, 2010; Löfgren 2013; also Nylund Skog this issue).

Thus, the novelty of the museum's excerpt collection was not that it concentrated a large number of previously dispersed collections in the same place; its significant contribution was rather in the overview it afforded. The excerpt collection created clarity in what otherwise threatened to remain just an unsorted mass of gathered material. As Orvar Löfgren (2013) emphasises, the excerpt collection as a general phenomenon can be understood as a mechanical technology for achieving searchability in large amounts of material. In modern terminology, he continues, the collection can be likened to an analogue search engine.

However, in the days when the Nordic Museum's excerpt collection was more regularly used by researchers, students and museum staff, it also did something else; by cutting up and redirecting the rich source material, the searchable catalogue marked out the direction for future research. Once the excerpt collection was in place, with all of its possibilities for strategic comparison and well-chosen insights, it was simultaneously a strong advocate of its own paradigmatic logic (cf. Svanberg 2008). More than anything else then, the excerpt collection was an academic device crying out to be used, and that also applies for those collections at the museum that were oriented towards findings of material culture. Markus Krajewski suggests that the card index should be regarded as a "paper machine" (2011:7). It is, so to speak, a machine built up by a large amount of single paper slips (or excerpts). The idea of the Nordic Museum's excerpt collection as a research machine underscores, in a similar but not identical way, the productive forces of the collection.

\section{The Excerpt Collection: From Historic Layers to Present day Historiography}

Today the same collection of diverse assertions regarding previous folklore, customs and beliefs has very much ceased to uphold this prominent status in the discipline. With their registry and their many cards and drawers, the two excerpt collections at the Nordic Museum represent a distinct landmark in a disciplinary landscape that, over time, has been drained of both people and activity (cf. Löfgren 2013). Which is, of course, not to say that they are completely deserted or out of use. You can still find some activities going on around the drawers. Nevertheless, today's ethnologists and folklorists seldom choose to utilise the ingresses into the world of ancient folk beliefs that lie hidden in this archive 
of folk memory. Perhaps more importantly, when it does happen, their gaze is usually directed towards the disciplinary conditions, assumptions and practices that once produced the collections (see, for example, Palmenfelt 1993; Lilja 1996, 1999; Nilsson 1996; Nordström 2002; cf. Skott 2008). Unlike at the time when the material was originally gathered and systematised, the value of the excerpts to present-day researchers is not as a source of older layers of folklore or folk memory; rather, the collection has been reduced to sediment and remains. It has become one historic layer comprised of previous researchers' academic ambitions and forms of knowledge.

Over recent decades, there have also been lively discussions as to the value and usefulness of these previously collected sources. However, in these analyses, this folkloric material generally figures as an example of the very idea of a folk tradition, rather than as something that contained the very existence of such a tradition. Thus when this older material is used these days, it is therefore typically viewed not as a research tool to sort out and reveal life forms on the verge of extinction, but rather as a relic that can tell us about the earlier assumptions that motivated the museum's actions and influenced the gatherings of collections. This is something entirely different from the older folklorists' understanding of the collected material as a valuable key to these still lingering folk memories. At the present time, the Nordic Museum's Folklore Collection, including the excerpts, tells us more about those asking the questions than those supplying the information. In other words, there has been a clear shift from answer to question -from the informant to the museum and researcher, and from an interest in the contents of the collection-to a focus on the conditions under which it was created and organised (Österman 1991; Richette 2003; Klein 2003; Nilsson 2004).

In summary, the excerpt collection at the Nordic Museum, which for decades upheld a status as a prominent resource for folk memory/folklife research and later ethnology, has been subjected to a process of academic rejection. The same knowledge that once appeared to be of great interest for the discipline is now considered dubious (for similar research regarding how previous fundamental knowledge within the discipline has been embraced, abandoned and contested over time, see Löfgren 1988, 1993:76; Skott 2010:76; Skott 2014; Gustavsson 2014:203; Nystrand von Unge 2019). It is as if neither the museum nor the discipline itself really want to acknowledge the grand scholarly project that once produced the countless catalogue cards, other than as objects for the museum's and the discipline's own historiography.

Of course, this gradual rejection of the excerpt collection from the discipline's mainstream activities can be understood in relation to the already introduced paradigm shift in methodology and preferred knowledge in ethnological research. However, it is more than that. As Orvar Löfgren (1996) subsequently confirmed, 
at the end of the 1960s it was important for the young, radical ethnologists of the period to distance themselves from their predecessors' deeds and motivations. Faced with the disciplines' historical tradition, it was necessary for the next-generation academics to shine a spotlight on the prevailing conditions of the present day. The Nordic Museum's excerpt collection was therefore drawn into a game of contrasting the past and future of such research, which was essentially a matter of creating an epistemological distance from the old. Just like The Swedish Atlas of Folk Culture (Erixon, ed. 1957), to this younger generation, the excerpt collection stood as a monument to the futile efforts of previous generations.

By definition, the frontline of research must be moved if an academic discipline is to remain relevant to its practitioners. This applies to a significant degree to the displacement in ethnology that many have attempted to place in this formative period. Like a troll cracking in the sunlight, the paradigm to which the excerpts gave expression (and themselves contributed to maintaining) could not withstand the demands for a new orientation in the discipline, as formulated by the new generation of ethnologists. In brief, that which Löfgren and other commentators conjure up is thus a picture of a once vital research tradition gradually being crushed beneath its own weight.

\section{To Storytellers and Collectors with Gratitude}

But what happens to the museum's excerpt collection when, over time, the subject's frontline creeps forward along different lines? Instead of being emptied of substance, the excerpt collection still remains important and relevant, although for a more limited group of people in comparison to its heyday. Admittedly, the academic aura of both the excerpts and the excerpt collection have been brought down to earth with a bump; however, this was not sufficient to wipe out in a single blow their status as valuable for learning and a receptacle of coveted knowledge. There is a straightforward explanation as to why this did not happen; quite simply, far too many people had invested far too much in the excerpts for them to be allowed to fail.

In Latourian language, the Nordic Museum's excerpt collection can be viewed as a blackboxed method or scientific practice that with time was drawn into the light, duly reviled and finally declared inadequate. With all of their individual catalogue cards, the large cabinets in the ground floor of the museum contain a story about how academic research is developed by new paradigms and schools of thought following on from the old. It is not unusual for new standard-bearers to feel a need to break new ground by clearly distancing themselves from their predecessors and their supposedly inadequate methods or pedantic knowledge goals (cf. Kuhn 1979). Nevertheless, if one overlooks the paradigmatic shift in the 
organisation of ethnological knowledge, and instead focuses on what has happened to the older learnings, that is, on the continuing circulation of knowledge, other conditions are revealed.

As ethnologists were presented with new questions, methods and theories with which to engage, a vacuum was also created around the excerpt collection. This was an emptiness simply waiting to be filled by other stakeholders (cf. Skott 2014). Subsequently, as ethnologists have moved on to other academic hunting grounds, it has been possible to integrate the excerpts into other knowledge projects. This is partly because other disciplines have not lived through ethnology's radical break with the past and have therefore continued to benefit from older findings in a different way. Even more clearly, it is also because this older learning has been incorporated into various types of less academic writing, aimed at a broader public, and fictionalised narratives.

This is where Therese Lindgren's tutorials enter the picture. On posting her fifth and final video on YouTube, Lindgren follows her clip about the tree sprite with a brief comment aimed at her followers. In this comment, she reveals the name of the book on folklore that she repeatedly refers to, Nordiska Väsen (2013) by Johan Egerkrans. This is the source of her voiceovers, with some editing of the original text on her part, that explain the folklore behind the various creatures. But from where has author and illustrator Egerkrans obtained his information?

In the book's unnumbered afterword, Egerkrans thanks a number of people for their help in realising the book and presents a vast number of different creatures from the Nordic region, using both text and his own spectacular illustrations. Among the editors and encouraging friends, one particular thank-you stands out. Here, he expresses his gratitude to,

All of the farmers, farmers' wives, farm labourers, peddlers, milk maids, sharecroppers, soldiers, parish constables, hunched old men and wise old women from long ago who shared all of these fantastic tales, and to all of the dedicated souls who collected them.

However, during the writing of the book, Egerkrans found no need to visit the excerpt collection at the Nordic Museum, with all its' material reminders of those long-gone storytellers and collectors. In a special thanks to the staff of Stockholm Public Library, he explains that the stories presented are based on already published works. On the final page, a number of familiar names appear among the references. The two names that dominate the literature list are Carl-Herman Tillhagen and Ebbe Schön. Here, in some general reference works and annotated publications from the archive, we find the sources where Egerkrans has been able to gather valuable information for his own book. 
Both Tillhagen and Schön have a past as directors of the Nordic Museum Folklore Collection and, as the above list demonstrates, they are also two folklorists whose careers and bibliographies are closely linked to the current excerpt collection. On scanning this literature list, it is therefore possible to state that a direct connection exists that unifies modern-day vlogger Therese Lindgren, author and illustrator Johan Egerkrans, the two head archivists and the Nordic Museum's excerpt collection. Such influences are not always so easy to trace, which is, of course, not to say that they do not exist.

The popular Sweden PAX series of books about the twins Alrik and Viggo Delling in Mariefred, for children in their younger teens, is yet another example of how ancient Nordic folklore is able to find new takers in our own time. The first book was published in 2014 and up to now it has been followed by eight more. All of these books feature a named folkloric creature in a central role: for example, the grim, the mare, the neck, the tilberi or the ghost. The literary form of the collaboration between authors Åsa Larsson and Ingela Korsell and illustrator Henrik Jonsson thus depends on the type of knowledge concerning folkloric characters that has been collected in droves (or rather on small catalogue cards) in the museum's archives. This has been channelled out over subsequent decades in books that bear varying degrees of academic and scientific hallmarks. Among many other recent possible examples of this kind of use and reuse of early findings are the Norwegian film Trolljägaren (2010); the Swedish film Gräns (2018)currently nominated as Sweden's candidate for the 2019 Oscars; books such as Stefan Spjut's Stallo (2012), which takes place in the borderlands between Nordic and Sami mythology (with a dollop of artist John Bauer), and Anders Fager's Swedish Cults (2009). Most recently, Ingela Korsell, one of the two coauthors involved in the PAX project, has presented a new book, Väsenologi (2019) on the same topic. Together with illustrator Reine Rosenberg she describes a wide range of beliefs with references to creatures from the Nordic region. This account also clarifies the fact that collected learning regarding folkloric creatures is now utilised to build careers other than the purely academic ones.

Other proponents have connected with the same material from a quite different angle. As Jonas Engman (2015) has pointed out, the excerpts and folklore archives have also been pulled into contemporary political contexts. When, in their 2015 party programme, the Sweden Democrats pointed to the existence of a "Community of Nordic Peoples", their argument rested on a cultural-heritage rhetoric that was both inclusive and exclusive, having its roots in the previous century's national romanticism and pan-Nordic movement. During the last few years the political uses of this material, to support nationalistic and right-wing agendas, has repeatedly been targeted by Swedish media. This was not least the case when the Sweden Democrats in December 2018 put forward a proposal to 
the Swedish Parliament, that there should be a national institute working for the benefits of adding elements of Nordic mythology, traditions, beliefs, and history to the Swedish gaming culture and products. In their argument, they particularly stated that Sweden's and the Nordic region's nature, mythology and cultural history must be considered a source of great inspiration for this steadily growing industry.

In summary, over the course of time the excerpt collection at the Nordic Museum has not solely functioned as a useful device to generations of researchers. Truly, it has also been a machine that has given rise to researchers. The museum and researchers have produced questionnaires and excerpts; however, once in place in the ordered collection, these excerpts have also produced research, methods, theories, terminology and, not least, researchers and individual careers. As Jonas Frykman confirmed, folklore research's excerpts were for a long time functional elements in a methodological and source-critical paradigm in which researchers and archives constituted "a union in which it was sometimes difficult to tell where the researcher ended and the archival system began" (Frykman 2010:257).

\section{Old Knowledge in new Streams}

As demonstrated above, once understood and utilised as a crucial resource in folklore research, the recorded material is neither abandoned nor forgotten. Rather, by emigrating from the archive's subject-oriented and topographic excerpt collections, it has moved on from a given academic discourse to other academic forums, and in an increasingly popular, and even political, direction. This carefully ordered and systematised archival material, which for more than half a century was a vital part of the Nordic Museum's scholarly endeavours, is nowadays a recurring feature of newspaper reports on the old traditions linked to Easter, Christmas or newcomer Halloween, but it can also be found in other streams and in the hands of new knowledge producers. Academic books and studies are still published in which the author, at least in part, or with new kind of questions, utilises the knowledge represented by the older excerpts. This applies not least to the vigorous research conducted within the framework of the folklore archive. Nevertheless, with a few notable exceptions, such as Jochum Stattin (1984), Malmberg (1991) and Inger Lövkrona (1996), the vast majority of ethnological research has long since chosen to look elsewhere, towards other source material. Accordingly, far from being a significant part of cutting-edge research, which they once were, the collection of excerpts in the Nordic museum has in many respects been tossed away by its own discipline.

This does not mean that the excerpt collection now lacks proponents or supporters. Contrarily, this "forgotten monument" is not quite as abandoned as one might think. The salient point is that it is mostly new visitors who stand flipping 
through the catalogue cards or who absorb the more readily available knowledge produced and published by researchers with long careers within the walls of the museum and archive. Today, it is no longer primarily ethnologists who write from a scholarly horizon on the folklore of, for example, forest nymphs or witchcraft (see Häll 2013; Malmstedt 2018). But still, some interests and stakeholders will not so easily change over time. Within disciplines such as religious history and Nordic languages, the excerpts have never ceased to be scholarly relevant. Moreover, for some people, efforts made and laurels won have stood in the way of the new direction that others have embraced. Among established folklorists and researchers some might consider it, therefore, a better alternative to hold onto the expertise, methods and theoretical points of departure that proved to be a key to previous success.

While the majority of academically active ethnologists have turned their backs on the Nordic Museum's excerpt collection, some of their colleagues remained; having said that, for these individuals too, something has fundamentally changed. The same excerpts that had once been perfectly suitable for achieving recognition for one's research, and that had once corresponded to the very idea of a legitimate material, were now the stuff of writing that found itself somewhat drifting towards a more popular, and less academic, position. Researchers such as Carl-Herman Tillhagen, Ebbe Schön and Jan-Öjvind Swahn can all be associated with an encyclopaedic knowledge rooted in the archive and excerpt collection. However, as the scholarly status of the excerpts plummeted in value, so too did the academic capital of these previously influential specialists. In the archive and extract collection, we can therefore discern the icy wind of a discreet dispute concerning disciplinary methodology, the value of the excerpt collection and, not least, the reputations and legacies of the researchers themselves.

Naturally, this tendency towards a less academic position regarding writing and career need not be considered in this way. Those persons mentioned have all gained a great reputation as experts on Swedish folk beliefs. Representatives of the folkloric field have also been able to combine academic reputation with an extensive, popular authorship. The most obvious examples of this are Ulf Palmenfelt and Bengt af Klintberg. However, this generally involves maintaining separation between the two forms of writing and readerships. Klintberg (1993) has personally stated that in the mid-1980s he chose to leave the ethnology field as he perceived that there was no longer room for the kind of text-oriented and source-oriented folklore expertise that he himself represented.

Eventually, it is also important to emphasise that, unlike the rather context-less extracts, the questionnaires as both material and method have in many respects survived into the present day as an ethnological resource (see, for example Hagström \& Marander-Eklund 2005; Hagström \& Sjöholm 2017). The earlier 
theories that once justified both the design of the questionnaires and the methods of their collecting have been abandoned. However, over time, much of what was found to be irrelevant data by previous generations of researchers has later on come to be considered valuable and useful (Waldetoft 2003:12f, cf. Nilsson 2003:112). Perhaps this shift in perspective most clearly illustrates the rupture with the older paradigm that once generated the subject-oriented and topographic extracts. With the questionaries' there is always the possibility to go back in the archive and search for the whole document that had originally been sent in to the museum, before its presumed legitimate findings were sorted out on the catalogue cards. For the continued use of the excerpt collection as relevant research material per se, there was the added difficulty that the slim information on the excerpts was already the result of a strategic cull of the larger data stream. Any hidden treasures that might have been of interest to later generations of researchers was for the most part exactly what the museum's enormous collection of excerpted transcripts has chosen not to preserve.

\section{The Excerpt as Museological Boomerang}

The Nordic Museum's excerpt collection can be compared to the practice of exhibiting, in the contemporary cultural or natural history museum, a preserved part of an old curiosity cabinet. In the same way that visitors may be both entertained and astonished over the curiosity cabinet's unexpected combinations of artefacts, the excerpt collection becomes both a cautionary and tender reminder of now bygone academic aspirations. Its function within the museum is thereby as an institutional keepsake; a stratification of previous researchers' ambitions and epistemology, gratefully used in the teaching of prospective ethnologists. However, despite the fact that the majority of ethnologists have ceased to ascribe it any specific value, apart from its position as a remnant and historiographic resource, the excerpt collection's accumulated knowledge continues to remain relevant and build careers in other fields.

The excerpt collection, and the knowledge it once represented, may have been relocated to other venues and other stakeholders, but it still occasionally wanders back to what might be considered its museological origins. Almost simultaneously to Therese Lindgren posting her tutorials on YouTube, the Nordic Museum took the initiative of arranging a Swedish National Championship in Cosplay, the Japanese form of costume play in which participants dress up as famous, generally pop-culture, figures. These are often characters taken from manga, computer games or fantasy literature (Winge 2019).

The Nordic Museum's competition was a variant of the same format, but with an added twist. Beginning in autumn 2016, the three finalists selected after 
a national qualifying round were invited to examine the museum's collection, before choosing a character of Nordic folklore to be present on the museum's own stage six months later. Before beginning, at the end of November, the finalists met individually with a number of the Nordic Museum's attendants, librarians and archivists. This was to allow them to familiarise themselves with the archive and artefact collection, so that they could "get to know trolls, forest nymphs, imps, elves, werewolves and other creatures". Later in the day, the finalists were invited to join the public at an open lecture on folkloric creatures given by Ebbe Schön, introduced as "Sweden's leading expert in the field".

The competition received a great deal of attention, even appearing in several items on Swedish television. The winner, Rickard Nilsson, chose to play an ancient mountain troll, with John Bauer's almost century-old illustrations being a clear influence on the make-up, mask and costume. As with Lindgren's introductory tutorials, those interested were able to follow the contestant's trials and tribulations, either through their own channels or via the museum's website and continuously updated blog.

As this event demonstrated, modern-day knowledge of folkloric characters is not confined to YouTube or as an obvious source of inspiration for books and films. On the contrary, it literally comes back to the museum. Neither is the presence of trolls and these other creatures at the museum's cosplay event a coincidence. This specific invitation reflects the museum's changing radius of action over time. Unlike the period in which the older folklore material was collected and made searchable and accessible through the museum's excerpt collection, today's Nordic Museum is less inclined to look exclusively back in time. The former taken for granted historical perspective is now challenged with the assumption that the real excitement might be happening right now, in our own day and age. As trolls and other creatures from the vast Nordic folklore fauna in a clearly folklorescque way have nowadays become a manifest element of popular culture, and thereby part of the everyday lives of young people and adults alike (cf. Foster \& Tolbert 2016, red.; see also Wall 2017), it is hardly remarkable that these costumed figures are also invited into the great hall of the museum.

The actual link to how these re-enacted characters are presented in the excerpt collection's catalogue cards can sometimes appear more than a little weak; however, from the museum's perspective, this is of little consequence. This is because the museum's widened scope of action has brought with it a different view of what can be considered valid knowledge. The old tradition's monumental efforts to gather, sort and preserve the diverse evidence of a disappearing folk culture has been replaced by an attitude towards knowledge and culture that places a premium on culture as process, performance and hybridisation. In this sense, there no longer exists any authentic expression of a given folk culture to 
collect and keep in drawers. What does exist, however, are occasions on which groups or individuals make use of the past's lingering repertoire of artefacts and beliefs to try on identities in the present. Naturally, the Nordic Museum remains a suitable stage for this kind of creativity.

Paradoxically, this also means that the world of popular beliefs that was once collected under the supervision of the museum's researchers is now also returning to the house of the father. Thus, once again it is true that when archival knowledge is used and reused it is also somehow changed (Gustavsson 2018, see also Östling 2015). Finally, after having spent so long a time under the radar of both the museum and the discipline of ethnology, this folklore material has gone through a process of pop-cultural revitalisation that has once again made it museologically desirable. When the museum opens its doors to a popular costume competition, it is therefore also keen to acquire the outfits of the three finalists. At the time of writing, no such acquisition has been made nor, for the purposes of our discussion, is this necessary. The salient point is the museum's stated ambition to inflate its collections with the costumes from the 2017 cosplay championship, in which participants interpreted the folk beliefs that have found their way out along various paths from the museum's at once dormant and highly active excerpt collection.

\section{A Network in Dissolution}

The excerpts in the Nordic Museum's Folklore Collection have a history that stretches back to the nineteenth century. Even if the number of catalogue cards will long remain the same, it must be affirmed that this is very much a story in the making; it is still being added to. The roots of the collection do not solely stretch down into the past, but also out into our own time-and nothing suggests that these connections will cease to work their way outwards in future. However, it remains an open question as to whether future ethnologists will make their peace with the excerpt collection. Perhaps they will; perhaps the collection will open itself up to new, vital fields and research questions. Something that suggests that this is the case is that several Swedish folklore archives have come together in a single digital platform to make available their own collections. Then again, maybe the excerpts will remain so associated with the central issues, methods, theories and research ideals of a previous era that, for many researchers schooled in present day ethnology, they will continue to generate a considerable epistemological fear of contact. This mechanism of rejection has not, however, infected everyone. As we have seen, other disciplines and non-academic stakeholders are not haunted by those severe problems that the ethnologists of the 1960s and 1970s associated with this older perspective, and with the excerpts as its material outcome. 
Consequently, when folk life researchers and ethnologists successively retreated from the field of research that gravitated around the lingering traces of past folk beliefs and customs, of which the excerpt collection constituted such a powerful and productive centre, this field was left free for others to claim.

To the extent that the Nordic Museum's excerpt collection is recognised as a resource by the academic institution that in many ways can be considered its nearest relative, that is, the ethnological environment at Stockholm University, it is nowadays primarily used as support for the teaching of new students. Here, the collection and catalogue cards fulfil a significant role in that a visit to the museum both provides a concrete opportunity for ethnology students to come into contact with their own research history and to acquaint themselves with archival material. A review of the institutions' own theses for the past two decades would, however, show few references to the museum's excerpt collection, something that underlines the reduced importance of the collection as an active and utilised research resource. What is considerably more difficult is to convey to the students an understanding of what a productive research machine the excerpt collection once was. Even if the collection were to get a new lease on life, it is unlikely that it will ever have the same significance. Without doubt, the material can still be used to deepen our understanding of both our own age and other eras. However, the accumulated network of relationships that once linked the excerpts, researchers, academic books and journals, and some scholarly careers to one another has long since fallen apart and faded into history.

Simon Ekström, is associated professor in Ethnology at Stockholm University. He is also part of CEMAS (Centre for Maritime Studies) at the same university. His research has since long been directed towards the production and circulation of different forms of authorized knowledge, often in relation to gender and media. Currently, he is working on a project that focuses on maritime museums as institutions and destinations marked with the presence of human death. Email: simon.ekstrom@etnologi.su.se 


\section{Notes}

1https://www.youtube.com/watch?v=vT9ZIluwY4s

2These collections were often established by individual researchers and museum staff. As an example museum official Gösta Berg is often mentioned as someone with a very large personal excerpt collection, the industrious use of which allowed him to achieve a bibliography of almost a thousand publications (Myrdal 2010). Excerpts, of all kind, could also be used as private resources to be traded, or given as gifts, to colleagues. 3Such spiritual artefacts might for example include a belief, legend or custom, although it could also be an individual fairy tale if this could be tracked in time and space.

4 Bo G. Nilsson places the change from evolutionism to diffusionism in the Swedish exploration of folk culture to somewhere around 1920 (2004:85ff).

5 For further information about Hammarstedt, see Nilsson 2004:93; af Klintberg 2010a (with additional reference to Bringeus 2006:106).

6 Questionnaires as a practical research resource are discussed in detail in two anthologies: Frågelist och berättarglädje. Om frågelistor som forskningsmetod och folklig genre (Nilsson, Waldetoft \& Westergren, eds. 2003), and Frågelistan som källa och metod (Hagström \& Marander-Eklund, eds. 2005).

7 In Paper Machines, About Cards and Catalogs, 1548-1929 Krajewski states, "The possibility of rearranging its elements makes the card index a machine: if changing the position of a slip of paper and subsequently introducing it in another place means shifting other index cards, this process can be described as a chained mechanism" (2011:7).

8 The change of name within the discipline was discussed in detail by Nils-Arvid Bringeus in 1988 (with specific reference to the chair at Lund University).

9 Elsewhere, Jonas Frykman (2010) has pointed to the possibility of discussing the use of excerpts and archives based on Bruno Latour's Actor-Network-Theory (ANT). Orvar Löfgren (2013) thinks along similar lines when he mentions archive material as coauthors and stakeholders. See also Matts Lindström (2017) regarding microfilm and Charlie Järpvall (2016) on copier paper.

10 https://www.youtube.com/watch?v=1_JXUtOVQxM

11 Among the listed titles are: Erotiska väsen; Folktro från förr; Folktrons ABC; Skepnader i skymningen-möten med folktrons väsen; Svensk folktro A till Ö-hur vi tänkt, trott och trollat; Troll och människa-gammal svensk folktro; Älvor, troll och talande trädfolktro om svensk natur (by Schön), as well as: Barnet i folktron -tillblivelse, födelse och fostran; Fåglarna i folktron; Vattnets folktro-sägen och berättelser kring bäckar, älvar, sjöar och hav (by Tillhagen).

12 https://www.riksdagen.se/sv/dokument-lagar/dokument/motion/ H602644, see also https://www.riksdagen.se/sv/dokument-lagar/dokument/motion/spel-som-kulturform H4022194

13 Staffan Bergwik has stressed that knowledge is never individual but rather systemic. Therefore, he argues, a science professor must be understood in relation to 
a functioning network of assistants, buildings, dinner parties, her/his own and other people's publications and, yes, even the professor's pen and desk, if they are to achieve a successful academic career (2016: 97ff, 126, see also Gustavsson 2014:192ff).

14 Source: $\underline{\text { https://www.nordiskamuseet.se/blogg/cosplay }}$

15 Source: https://www.nordiskamuseet.se/kalendarium/foredrag-lar-kanna-folktrons-vasen

16 The two remaining finalists chose to play a mountain nymph and forest nymph respectively.

17 As stated in the competition entry form: "It is desirable that, within one year of the completion of the competition, participants donate their costumes to the Nordic Museum's costume collection to be preserved for posterity (NB, this entirely voluntary)". Source: https://www.nordiskamuseet.se/artiklar/tavlingsregler-cosplay 18 These different perspectives, that is to say, the lingering and the ongoing, respectively, can of course be seen as two sides of the same coin.

19 See the map at: http://www.sprakochfolkminnen.se/om-oss/kartor/sagenkartan. $\underline{\mathrm{html} \# / \text { places }}$

20 It should though be emphasised that in other ethnology institutions, such as in Lund, such a review would probably yield a different result. Here, collaboration with the university's own folklore archive has demonstrated considerably more vitality over time.

21 As stated earlier, perhaps further achievement on the field will prove this rather gloomy prediction wrong. There are actually some promising signs that the excerpts have gained renewed interest from scholars within the discipline of folklore studies (se for instance Harjunen 2017).

\section{References}

\section{Internet Sources}

https://www.youtube.com/watch?v=vJ9ZIluwY4s (visited 16.01.2018)

https://www.youtube.com/watch?v=1 JXUtOVQxM (visited 16.01.2018)

https://www.riksdagen.se/sv/dokument-lagar/dokument/motion/_H602644 (visited 29.08.2019)

https://www.riksdagen.se/sv/dokument-lagar/dokument/motion/spel-som-kulturform H4022194 (visited 29.08.2019)

Source: https://www.nordiskamuseet.se/blogg/cosplay (visited 21.02.2018)

Source:https://www.nordiskamuseet.se/kalendarium/foredrag-lar-kanna-folktrons-vasen (visited 23.01.2018)

https://www.nordiskamuseet.se/artiklar/tavlingsregler-cosplay (visited 21.02.2018).

http://www.sprakochfolkminnen.se/om-oss/kartor/sagenkartan.html\#/places (visited 21.08.2018) 


\section{Culture Unbound}

Journal of Current Cultural Research

\section{Literature}

Atlas över svensk folkkultur. 1, Materiell och social kultur. Åke Campell \& Sigurd Erixon (eds.) (1957). Uppsala: Lundequistska bokhandeln.

Atlas över svensk folkkultur. 2, Sägen, tro och högtidssed. Åke Campbell \& Åsa Nyman (eds.) (1976). Uppsala: Lundequistska bokhandeln.

Bergwik, Staffan (2016): Kunskapens osynliga scener. Vetenskapshistorier 1900-1950. Göteborg/Stockholm: Makadam.

Bringeus, Nils-Arvid (1988): "Lärostolen och ämnesbeteckningen". Nils-Arvid Bringeus (ed.): Folklivsarkivet $i$ Lund 1913-1988. En festskrift till 75-årsjubileet. Lund: Folklivsarkivet, 123-143.

Bringeus, Nils-Arvid (2006): Carl Wilhelm von Sydow som folklorist. Uppsala: Kungl. Gustav Adolfs akademien för svensk folkkultur.

Bolter, Jay David \& Richard Grusin (1999): Remediation. Understanding New Media. Cambridge, Mass.: MIT Press.

Burke, Peter (2016): What is the History of Knowledge? Cambridge: Polity Press.

Daun, Åke (1969): Upp till kamp i Båtskärsnäs. En etnologisk studie av ett samhälle inför industrinedläggelse. Uppsala: Verdandi.

Egerkrans, Johan (2013): Nordiska väsen. Stockholm: B. Wahlström.

Engman, Jonas (2015): "Folklivsarkivens ideologiska och politiska kontexter. Neonationalism och kulturarvets popularisering". Marianne Larsson et al. (eds.): Utkanter och marginaler. 31 texter om kulturhistoria. Stockholm: Nordiska museet, 20-27.

Fager, Anders (2009): Svenska kulter. Göteborg: Man av skugga.

Foster, Michael Dylan \& Jeffrey Tolbert (eds.) (2016): The Folkloresque. Reframing Folklore in a Popular Culture World. Logan: Utah State University Press.

Frykman, Jonas (1988): "Folklivsarkivet, frågelistorna och forskningen". Nils-Arvid Bringeus (ed.): Folklivsarkivet i Lund 1913-1988. En festskrift till 75-årsjubileet. Lund: Folklivsarkivet, 91-107.

Frykman, Jonas (2010): "Brita Egardt (1916-1990)". Mats Hellspong \& Fredrik Skott (eds.): Svenska etnologer och folklorister. Uppsala: Kungl. Gustav Adolfs akademien för svensk folkkultur, 253-260.

Frågelist och berättarglädje. Om frågelistor som forskningsmetod och folklig genre. Bo G. Nilsson, Dan Waldetoft \& Christina Westergren (eds.) (2003). Stockholm: Nordiska museet.

Frågelistan som källa och metod. Charlotte Hagström \& Lena Marander-Eklund (eds.) (2005). Lund: Studentlitteratur.

Gustavsson, Karin (2014): Expeditioner $i$ det förflutna. Etnologiska fältarbeten och försvinnande allmogekultur under 1900-talets början. Stockholm: Nordiska museet. Diss.

Gustavsson, Karin (2018): “Kulturforskningar i Tornedalen. Fältarbete och resultat från 1922 års Norrbottensexpedition”. Svenska landsmål och svenskt folkliv, 2017, 27-53.

Gustavsson, Lotten Reinius (2013): "Kongobussen kommer! Den etnografiska vandringsutställningen som ett missionerande medium". Lotten Gustafsson Reinius, Ylva Habel \& Solveig Jülich (eds.): Bussen är budskapet. Perspektiv på mobilitet, materialitet och modernitet. Stockholm: Kungliga biblioteket, 29-53.

Gustavsson, Per \& Ulf Palmenfelt (2017): Insamlarna. Folksagan i Sverige 1. Stockholm: Carlsson.

Harjunen, Catarina (2017): "Queera möten i finlandssvenska folksägner". Laboratorium för folk och kultur, 2017:2.

Hagström, Charlotte \& Carina Sjöholm (2017): "Nya frågor till gamla svar. Frågelistor som kulturhistorisk källa”. Fredrik Nilsson \& Lars-Eric Jönsson (eds.): Kulturhistoria. En etnologisk metodbok. Lund: Lunds universitet, 137-154. 


\section{Culture Unbound}

Hellspong, Mats (2003): "Den glansfulla Sigurd Erixon-epoken: den Hallwylska professuren 1934-1955". Mats Hellspong (ed.): Lusthusporten. En forskningsinstitution och dess framväxt 1918-1993. Festskrift till den Hallwylska professuren $i$ folklivsforskning $i$ Stockholm vid dess 75-årsjubileum. Stockholm: Nordiska museet, 52-73.

Hjarvard, Stig (2013): The Mediatization of Culture and Society. London: Routledge.

Häll, Mikael (2013): Skogsrået, näcken och djävulen. Erotiska naturväsen och demonisk sexualitet i 1600- och 1700-talens Sverige. Lund: Lunds universitet. Diss.

Jülich, Solveig (2015). "The Making of a Best-Selling Book on Reproduction: Lennart Nilsson's 'A Child Is Born'”. Bulletin of The History of Medicine, 2015:3, 491-526.

Järpvall, Charlie (2016): Pappersarbete. Formandet av och föreställningar om kontorspapper som medium. Lund: Lunds universitet. Diss

Klein, Barbro (2003): "Nm 223 Personlig hygien. Reflektioner kring frågelistor, meddelarsvar och vetenskap". Bo G. Nilsson, Dan Waldetoft \& Christina Westergren (eds.): Frågelist och berättarglädje. Om frågelistor som forskningsmetod och folklig genre. Stockholm: Nordiska museet, 69-88.

Klintberg, Bengt af (1993): "En folklorists hågkomster från Lusthusporten”. Mats Hellspong (ed.): Lusthusporten. En forskningsinstitution och dess framväxt 1918-1993. Festskrift till den Hallwylska professuren $i$ folklivsforskning $i$ Stockholm vid dess 75-årsjubileum. Stockholm: Nordiska museet, 150-170.

Klintberg, Bengt af (2010a): "Nils Edvard Hammarstedt (1861-1939)". Mats Hellspong \& Fredrik Skott (eds.): Svenska etnologer och folklorister. Uppsala: Kungl. Gustav Adolfs akademien för svensk folkkultur, 33-40.

Klintberg, Bengt af (2010b): "Carl-Herman Tillhagen (1906-2002)". Mats Hellspong \& Fredrik Skott (eds.): Svenska etnologer och folklorister. Uppsala: Kungl. Gustav Adolfs akademien för svensk folkkultur, 211-218.

Krajewski, Markus (2011): Paper Machines. About Cards and Catalogs 1548-1929. Cambridge/Mass.: MIT Press.

Korsell, Ingela (2019): Väsenologi. En lättbegriplig vetenskapligt grundad faktabok om väsen i nordisk folktro. Stockholm: Natur och Kultur.

Kuhn, Thomas (1979): De vetenskapliga revolutionernas struktur. Lund: Doxa.

Lilja, Agneta (1996): Föreställningen om den ideala uppteckningen. En studie av idé och praktik vid traditionssamlande arkiv: ett exempel från Uppsala 1914-1945. Uppsala: Uppsala universitet. Diss

Lilja, Agneta (1999): "Kollektiva beskrivningar och individuella berättelser". Magnus Bergquist \& Birgitta Svensson (eds.): Metod och minne. Etnologiska tolkningar och rekonstruktioner. Lund: Studentlitteratur, 115-134.

Lindström, Matts (2017): Drömmar om det minsta. Mikrofilm, överflöd och brist: 1900-1970. Stockholm: Stockholms universitet. Diss

Lundby, Knut (ed.), (2009): Mediatization. Concept, Changes, Consequences. New York: Lang.

Löfgren, Orvar(1988): “Ettämne väljer väg”. Nils-Arvid bringeus (ed.): Folklivsarkivet $i$ Lund 1913-1988. En festskrift till 75-ärsjubileet. Lund: Folklivsarkivet, 144-166.

Löfgren, Orvar (1993): "På John Granlunds tid: Lusthusporten 1955-1969”. Mats Hellspong (ed.): Lusthusporten. En forskningsinstitution och dess framväxt 1918-1993. Festskrift till den Hallwylska professuren $i$ folklivsforskning $i$ Stockholm vid dess 75-årsjubileum. Stockholm: Nordiska museet, 74-107.

Löfgren, Orvar (1996): "Sakletarna. Om det materiellas betydelse i etnologin". Åke Daun (ed.): Ting, kultur, mening. Stockholm: Nordiska museet, 137-160.

Löfgren, Orvar (2013): "Arkivlådan. Konsten att bygga en analog sökmotor". Charlotte Hagström, Göran Sjögård \& Carina Sjöholm (eds.): Folklivsarkivet $i$ Lund 100 år. Lund: Lunds universitet, 30-38.

Lövkrona. Inger (1996): "Suktande pigor och finurliga drängar". Britta Lundgren, Inger Lövkrona \& Lena Martinsson (eds.): Atskilja och förena. Etnologiskforskning om betydelser av kön. Stockholm: Carlsson, 87-182. 


\section{Culture Unbound}

Journal of Current Cultural Research

Malmberg, Denise (1991): Skammens röda blomma. Menstruationen och den menstruerande kvinnan i svensk tradition. Uppsala: Uppsala universitet. Diss

Malmstedt, Göran (2018): En förtrollad värld. Förmoderna föreställningar och bohuslänska trolldomsprocesser 1669-1672. Lund: Nordic Acadmic Press.

Myrdal, Janken (2010): "Gösta Berg (1903-1993)". Mats Hellspong \& Fredrik Skott (eds.): Svenska etnologer och folklorister. Uppsala: Kungl. Gustav Adolfs akademien för svensk folkkultur, 187-184.

Nilsson, Bo G. (1996): Folkhemmets arbetarminnen. En undersökning av de historiska och diskursiva villkoren för svenska arbetares levnadsskildringar. Stockholm: Nordiska museet. Diss.

Nilsson, Bo G. (2003): "Frågor, svar och vad mer?" Bo G. Nilsson, Dan Waldetoft \& Christina Westergren (eds.): Frågelist och berättarglädje. Om frågelistor som forskningsmetod och folklig genre. Stockholm: Nordiska museet, 105-116.

Nilsson, Bo G. (2004): "Framtidens salt: om museernas och folklivsforskarnas bidrag till folkhemsbygget". Bo G. Nilsson, Cecilia Hammarlund-Larsson \& Eva Silvén (eds.): Samhällsideal och framtidsbilder. Perspektiv på Nordiska museets dokumentation och forskning. Stockholm: Nordiska museet/Carlsson, 67-139.

Nordström, Annika (2002): Syskonen Svensson - sångerna och livet. En folklig repertoar i 1900-talets Göteborg. Göteborg: Göteborgs universitet. Diss.

Nystrand von Unge, Elin (2019): Samla samtid. Insamlingspraktiker och temporalitet på kulturhistoriska museer. Stockholm: Vulkan. Diss.

Palmenfelt, Ulf(1993): Per Arvid Säves möten med människor och sägner. Stockholm: Carlsson. Diss.

PAX I-X (2019): Ingela Korsell, Åsa Larsson \& Henrik Jonsson. Stockholm: Bonnier Carlsen.

Richette, Christian (2003): "Frågelistan. Ett kontextkritiskt perspektiv". Bo G. Nilsson, Dan Waldetoft \& Christina Westergren (eds.): Frågelist och berättarglädje. Om frågelistor som forskningsmetod och folklig genre. Stockholm: Nordiska museet, 117-130.

Salomonsson, Anders (2003): "Folklivsarkivet och frågelistorna". Bo G. Nilsson, Dan Waldetoft \& Christina Westergren (eds.): Frågelist och berättarglädje. Om frågelistor som forskningsmetod och folklig genre. Stockholm: Nordiska museet, 89-100.

Secord, James (2004): “Knowledge in Transit”. Isis, 2004:4, 654-672.

Skott, Fredrik (2008): Folkets minnen. Traditionsinsamling $i$ idé och praktik 1919-1964. Göteborg: Göteborgs universitet. Diss

Skott, Fredrik (2010): "Hilding Celander (1876-1965)". Mats Hellspong \& Fredrik Skott (eds.): Svenska etnologer och folklorister. Uppsala: Kungl. Gustav Adolfs akademien för svensk folkkultur, 69-78.

Skott, Fredrik (2014): "Folkloristiken och folkminnesarkiven". Rig, 2014:1, 32-36.

Spjut, Stefan (2012): Stallo. Stockholm: Bonnier.

Stattin, Jochum (1984): Näcken. Spelman eller gränsvakt. Lund: Lunds universitet. Diss.

Fredrik Svanberg (2008): "Museum Narration and the Collecting Machine: Or how Collections Make Collectors". Peter Aronsson \& Andreas Nyblom (eds.): Comparing: National Museums, Territories, Nation-Building and Change. NaMu IV. Linköping, University, Norrköping, Sweden 18-20 February 2008. Conference Proceedings, 175-182.

Svensson, Sigfrid (1942): Bygd och yttervärld. Studier över förhållandet mellan nyheter och tradition. Stockholm: Nordiska museet.

Waldetoft, Dan (2003): "Vad vill vi med våra frågelistor?" Bo G. Nilsson, Dan Waldetoft \& Christina Westergren (eds.): Frågelist och berättarglädje. Om frågelistor som forskningsmetod och folklig genre. Stockholm: Nordiska museet, 9-18. 
Wall, Tora (2017): "Folklore och turism: om bruket av väsen i turistattraktioner". Laboratorium för folk och kultur, 2017:2.

Westergren, Christina (2003): "Meddelare, kvinnor och vanliga människor" Bo G. Nilsson, Dan Waldetoft \& Christina Westergren (eds.): Frågelist och berättarglädje. Om frågelistor som forskningsmetod och folklig genre. Stockholm: Nordiska museet, 17-32.

Winge, Theresa (2019): Costuming Cosplay. Dressing the Imagination. London: Bloomsbury Visual Arts.

Åhrén, Eva Snickare (2004): "Känn dig själv! Om vaxkabinett och anatomiska utställningar". Anders Ekström (ed.): Den mediala vetenskapen. Nora: Nya Doxa, 59-87.

Österman, Annika (1991): Människors egen historia. Om Nordiska museets frågelistverksamhet. Stockholm: Nordiska museet.

Östling, Johan (2015): "Vad är kunskapshistoria?”. Historisk tidskrift, 2015:1, 109-119.

Östling, Johan \& David Larsson Heidenblad (2017): “Cirkulation—ett kunskapshistoriskt nyckelbegrepp". Historisk tidskrift, 2017:2, 269-284. 


\title{
"...of immediate use to society". On Folklorists, Archives and the Definition of "Others"
}

\author{
By \\ Charlotte Hyltén-Cavallius \& Lotta Fernstål
}

\begin{abstract}
This article focuses on archival collections relating to so-called "tattare" and "zigenare" (roughly translated as "tinkers" and "gypsies") created by Swedish folklore scholars during the twentieth century, and how these scholars influenced politics and interventions regarding these categories. It addresses questions regarding the production of knowledge about these categories and the contexts, structures and actors that have created the basis for these kinds of collections. Special focus has been placed on works by the folklore scholars Carl-Martin Bergstrand and Carl-Herman Tillhagen, and collections at the Institute for Language and Folklore, Department of Dialectology, Onomastics and Folklore Research and the Nordic Museum. By unfolding the networks of Bergstrand and Tillhagen and following the traces of their work to other archives, the article highlights some of the political and monitoring dimensions of archival practices in relation to minority groups in Sweden.
\end{abstract}

Keywords: "Zigenare", "Tattare", Folklore archives, Follow a label, Follow the researcher, Political and ideological context, Monitoring power, Multi-sited archives.

Hyltén-Cavallius, Charlotte \& Lotta Fernstål: ““...of immediate use to society’. On Folklorists, Archives and the Definition of 'Others'”, Culture Unbound, Volume 12, issue 1, 2020: 141-172. Published by Linköping University Electronic Press: http:// www.cultureunbound.ep.liu.se 


\section{Introduction}

This article focuses on archival collections relating to so-called "tattare" and "zigenare" that were created by Swedish folklore scholars in the mid-twentieth century, and how these scholars influenced politics and interventions regarding these categories. " "Tattare" and "zigenare" are Swedish words that roughly translates as "tinkers" and "gypsies", but we will soon give a more detailed introduction to the Swedish labels. The aim of this article is to create a deeper understanding for the formation of the labels and categories "tattare" and "zigenare" in Swedish archival collections and the production of knowledge regarding these, by unfolding networks of actors involved in these processes and their positions. In doing so, we also aim to show the wider societal consequences of these formation processes.

We are especially interested in questions regarding the production of knowledge about these categories and the contexts, structures and actors that have created the basis for these kinds of archival collections. The concept of archive, used in Swedish since the seventeenth century, derives from the Latin word archivum, which in turn derives from the Greek word archeion-denoting the actual place of power, "initially a house, a domicile, an address, the residence of the superior magistrates, the archons, those who commanded" (Derrida 1996: 2, cf. Hammarlund 2015: 10-11). The archive is therefore an archetypical locus of power. Following the discussion below, modern archives are also institutions of power, and in this article, we strive to show how this power came about (cf. Derrida 1996).

\section{Point of Departure}

The creation of a collection and the understanding of its materiality is, as pointed out by Barbara Kirshenblatt-Gimblett (1998) and many others after her, an ongoing cultural process, often as much, or even more related to, and dependent on, circumstances in the present than to the historical pasts of these cultural fragments. Archives and museums in northern Europe have served as important resources in the construction of national and regional symbols (e.g. Aronsson 2004, Klein 2000, 2007, 2009). In the process of creating collections, archives have become concrete historical records, mirroring and hosting traditions and collective heritages. The folklore archives are therefore in themselves historical artefacts, created in a specific time and place, and by certain individuals with specific aims and methods (cf. Klein 2009, Lilja 1996, 2004, Nilsson 1996, Nylund Skog 2017, Skott 2008, 2016).

The archival procedure of selecting, gathering, documenting, describing, classifying and assembling different kinds of documents and records in a specific place is an exercise of power. Archives are thus potential instruments for political 
control and the wielding of power, and sometimes abuses of power. Therefore, it is important to thoroughly investigate the perspectives and ideologies that have been in motion during the formative phases of a collection.

As mentioned above, the aim of this article is to create a deeper understanding of the formation of the labels and categories "tattare" and "zigenare" in Swedish archival collections and the production of knowledge regarding these. We also aim at showing the wider societal consequences of these formation processes. In order to achieve this, our starting point is the roles of the folklore scholars Carl-Martin Bergstrand and Carl-Herman Tillhagen, who were deeply engaged in the "tattare and zigenare questions" from the late 1930s to the 1960s. Bergstrand and Tillhagen worked with the collections and the production of knowledge regarding "tattare" and "zigenare" for several decades; Bergstrand at the West Swedish Folklore Archive (currently the Institute for Language and Folklore, Department of Dialectology, Onomastics and Folklore Research) and Tillhagen at the Nordic Museum, and collections at these institutions will initiate our discussion.

Carl-Martin Bergstrand (1899-1998) was a Swedish folklorist and head of the West Swedish Folklore Archive in Gothenburg between 1931 and 1964. Bergstrand studied at Lund University and took courses led by the folklore scholar Carl Wilhelm von Sydow in 1923. During the summers in the 1920s, he collected material for the archives in Uppsala and Lund. He received a bachelor's degree, but never completed a doctoral dissertation. This status, of not having a higher degree, most certainly had an effect on Bergstrand's leadership and his relationship with other folklorists and archives in the field (cf. Skott work in progress). Bergstrand's sense of being in a subordinate position can be seen in his correspondence and academic disagreements with other scholars. ${ }^{2}$ Carl-Herman Tillhagen (1906-2002) studied at Uppsala University and Stockholm College during the 1930s and 1940s and was offered a teaching position at the Nordic Museum in 1939. He was connected to the Nordic Museum until his retirement in 1971-1972. For the most part, Tillhagen worked with subjects such as traditional games, dances, amusements and vernacular healing, and the latter was also the topic of his doctoral dissertation from 1960 (af Klintberg 2010, Tillhagen 1958). ${ }^{3}$

Bergstrand and Tillhagen were both engaged in societal aspects of the "tattare and zigenare questions" of their time, and to understand the impact of their work, the method of only studying the archival contents of "their" collections at "their" archives is not sufficient. To understand if, and how, they may have affected the meaning and use of these labels in a broader sense, we have to use another methodological approach. We have, therefore, used the method of following the researchers and the labels in the archives through time and different archival spaces and societal contexts (cf. Czarniawska 2007). We began at the archives where Bergstrand and Tillhagen worked, and from there we followed the traces 
of their activities to other archives. This methodology is similar to multi-sited ethnography, i.e. moving from a single site and local situation, in this case single archives, to follow and investigate a certain phenomenon or aspect through different terrains and stops or locations (e.g. Marcus 1995). This means that it is the question investigated, and not merely a specific collection or geographical area that establishes the boundaries for our study.

Several critical investigations have previously been performed concerning the role of societal institutions in the structural discrimination of so-called "tattare" and "zigenare" during the twentieth century in Sweden, including the school, the church, municipalities and governmental agencies (Ericsson 2012, Ohlsson al Fakir 2013, Selling 2014, Sjögren 2010, Vitboken 2014, Westin et al. 2014). The role of folklore scholars, however, and archives as knowledge-producers and the scholars' influence as "cultural history experts", have mostly been overlooked (see, however, Montesino 2001; Ohlsson al Fakir 2015). Therefore, the role of the folklore scholars and the archives as a basis for knowledge production have, to a great extent, been underestimated, especially with regards to the scholars' influence on the monitoring of the categories "tattare" and "zigenare" and their involvement in the processes of defining the boundaries of these categories. With this article we hope to fill this gap.

\section{The Labels "Tattare" and "Zigenare": A Background}

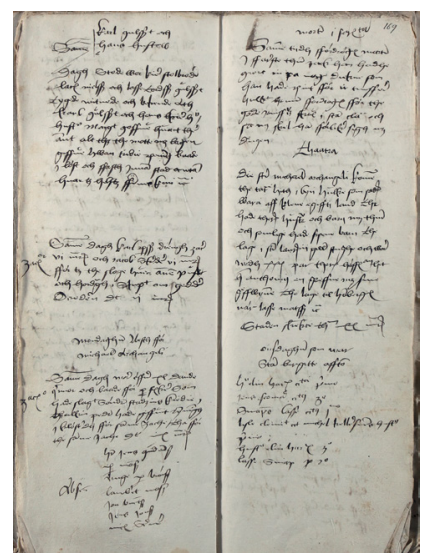

Fig 1. The middle section on the right page is the entry in Stockholm Municipal Court Records from 1512 that mentions a travelling group of people called "tatra" (in modern Swedish "tattare"). Translation into a modernized language: 
Tattare

On the Archangel St. Michael's Day [September 29], tattare arrived at the town, who were said to come from the land of Little Egypt. They had their wives and children with them, and some had infants. They got shelter in Sankt Lars' guildhall and were thirty couples. Their captain was called Mr Antonius, a count with his countess. They were in the lodge when Lasse Matsson etc.

The town gave them twenty marks. (Photo: Stockholm City Archives.)

The first documented mention in Sweden of people labelled "tattare" is from 1512, when a travelling group of women, men and children arrived in Stockholm on the day of Saint Michael the Archangel, i.e. September 29 (see fig. 1). The word used in the Stockholm Municipal Court Records was "tatra" (Stockholms stads tänkeböcker 1504-1514, 1931). Authorities and cultural institutions have since then had a long-lasting interest in groups defined by the majority as "tattare" and "zigenare". There are thus many sources regarding these groups in the archives. The information given, however, usually mirrors the often prejudiced view of the majority population; this prejudiced view, with its long historical roots, is often described with the term antigypsyism (or antiziganism). This term is widely used in order to highlight structural discrimination and racism directed toward Roma groups today and historically toward people defined by the majority as "zigenare" and "tattare" (e.g. Selling 2014, SOU 2010, Vitboken 2014, Westin et al. 2014). It is similar to the term antisemitism, i.e. hostility and prejudices against Jews, in that antigypsyism stresses the prejudices and pre-conceptions of the majority population about Roma, as well as myths with long historical trajectories. Therefore, the concept deals with a stereotyped and excluding image of Roma past and present. This structure has caused persecution, violence and discrimination as well as assimilation interventions in all societal spheres, from civil society to schools, congregations, municipalities and the state (e.g. Montesino 2002, 2010, Montesino \& Ohlsson al Fakir 2015, Ohlsson al Fakir 2013, Selling 2014, Vitboken 2014, Westin et al. 2014).

One of the oldest sources in a Swedish cultural history archive is a handwritten essay from 1780 by Christfrid Ganander, which is kept in the archive of the Royal Swedish Academy of Letters, History and Antiquities (Fernstål \& Hyltén-Cavallius (eds) 2018b). The essay was the result of a history competition announced by the academy and its title is quite revealing regarding earlier uses of the different labels as synonyms (our translation, see fig. 2): Investigation about the so-called Tattare or Zigeuner, Cingari, Bohemians. Their origin, ways of living, language etc. And about when and where some of them settled in Sweden? 


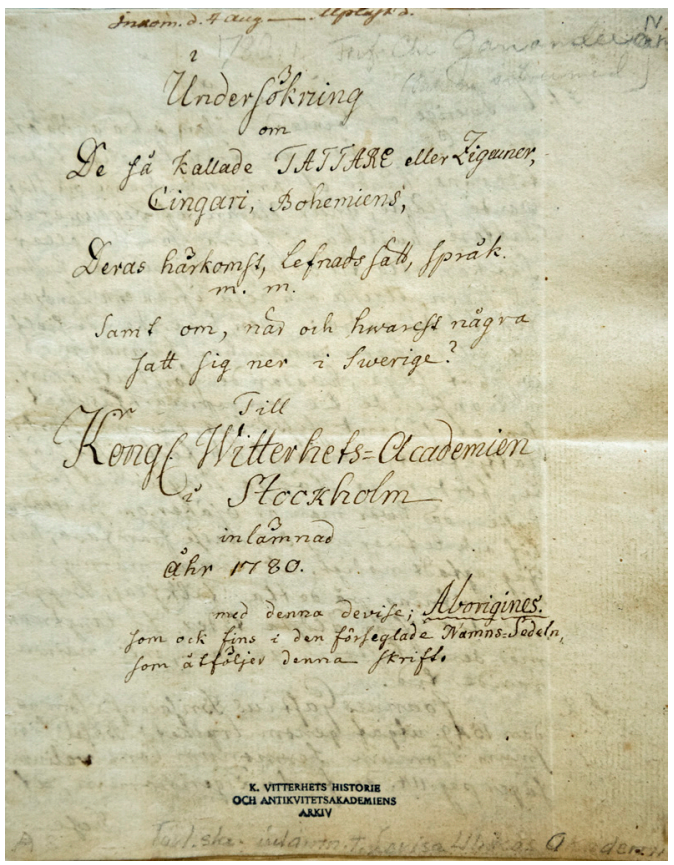

Fig. 2. The title page of the essay Undersökning om De så kallade Tattare eller Zigeuner, Cingari, Bohemiens, Deras härkomst, lefnadssätt, språk. m. m. Samt om, när och hwarest några satt sig ner i Swerige? from 1780, by Christfrid Ganander. The essay is at the archive Antikvarisk-Topografiska arkivet, the National Heritage Board, Stockholm. Photo: Katarina Nimmervoll, the National Historical Museums, Sweden.

The terms "cingari" and "bohemians" have not been as commonly used in Swedish as "tattare" and "zigenare", but the latter two were, until the beginning of the twentieth century, often used alternately and as synonyms (e.g. Fernstål \& Hyltén-Cavallius forthcoming A, Blomster 2015: 15, Montesino 2002: 33, 96, 2010: 8). The separation of the two labels came about when people who were mainly called "zigenare"-migrating from Russia and other parts of Europe at the beginning of the twentieth century-stayed permanently in Sweden because of World War I and the Aliens Act of 1914 which prohibited foreign "zigenare" ("utländsk zigenare") from entering Sweden (the Swedish Code of Statutes SSF 1914: 196). Thus, leaving Sweden would have made a return quite uncertain. The label "zigenare" came to be used mainly for the "newcomers" and "tattare" for people already living in Sweden (e.g. Fernstål \& Hyltén-Cavallius (eds) 2018a: 22-23).

In a census of the population of Sweden in 1910, the labels were, however, still used as synonyms; the number of individuals considered to be "zigenare or tattare" was given as one group. This came with a note that explains that although "tattare" were considered to be people of mixed descent between "zigenare" and the "native 
population", the labels had not been used in accordance with this distinction during the census (Folkräkningen 1918: 32). In an investigation regarding vagrancy in 1923, which also included a census of "tattare" and "zigenare", suggested solutions regarding the labelled groups are mostly discussed separately. "Tattare" were long assumed to have Swedish citizenship, while "zigenare" may have Swedish citizenship or unclear citizenship status; either way the latter were definitely, according to the investigation, further from Swedish society in their habits and ways of living (SOU 1923: 85-91, 321, appendix 2). Here as well, "tattare" were considered a mix between, most often, "a zigenare and a Swedish woman" (SOU 1923: 89). The official view was that the labelled groups were separate from each other, but whether or not the local civil registry offices and police offices, giving the numbers for each group, followed the same view, is something we do not know for sure.

During the next census of "tattare" and "zigenare" at the beginning of the 1940s, the investigators encountered new difficulties. The census of "zigenare" was seemingly easily carried out by local police officers who visited camps all over Sweden on May 31 1943. But who was to be defined as "tattare" compared to the rest of the population of Sweden? That census required more work, such as a physical anthropological examination of some "tattare" ("Zigenarnas antal och levnadsförhållanden" 1944: 116). It may be noted that by that time, the main question was not who was "tattare" and who was "zigenare", but who was "tattare" compared to the majority population. After this, two more official censuses of "zigenare" were carried out, in the 1950s and 1960s, but no longer of "tattare" (SOU 1956, Takman 1966, 1976).

The labels "tattare" and "zigenare" have been ascribed to people according to the views of authorities, census-takers and civilians, which have varied through time, even from decade to decade during parts of the twentieth century. How many of the individuals who were labelled as "zigenare" and "tattare" that also identified themselves as such we cannot know. Many of the individuals labelled "zigenare" probably called themselves "zigenare" in Swedish at the time, and many did so until approximately the beginning of the twenty-first century when it was largely replaced by romer (Engl. Roma), from le rom in Romani (see Fernstål \& Hyltén-Cavallius (eds) 2018a: 23). This change in terminology came about when Roma in 1999 became one of the recognized national minority groups in Sweden, comprising several groups of Roma, e.g. Swedish Roma, Finnish Roma and resande, which in Swedish means "travellers". Belonging to the minority is based on self-identification, which means that it is up to the individual to decide if he or she identifies as Roma (e.g. SOU 2010: 82; the Swedish Code of Statutes SSF 2009: 724). 
The correlation between being labelled "zigenare" and self-identification, however, was thus not always given. In one of the forms from the census of 1943 it is noted that the individual declared that he was not a "zigenare", but the investigators still recorded him as " $1 / 2$ " on the form, i.e. half "zigenare". 4 To be registered for a census by the police during World War II was to be exposed to a form of power abuse (cf. Kotljarchuk 2017). There may have been many who did not dare to state their opinion concerning their identity or to be registered and the calculation by the investigators on many of the forms, regarding how much of a "zigenare" each individual was, to a detail of e.g. $1 / 4,6 / 8$ or $7 / 8$, quite clearly indicates that this did not have much to do with the self-identification of the registered individuals.

When it comes to the label "tattare", the discrepancy is even bigger. Few people have, most likely, ever called themselves "tattare". Still, there is often the perception that the earlier label "tattare", to a great extent, corresponds to the identity of resande today or earlier (see e.g. Ericsson 2015: 15-19, Tervonen 2010: 31, 258-259, Wiklander 2015: 647-648). Many who would have identified as resande were probably labelled as "tattare", but many other people were, most likely, also labelled "tattare" as the term was used quite widely, with large uncertainties regarding what it actually meant, as we have seen above.

The labels "zigenare" and "tattare" were used as labels by authorities and civilians alike, most often without asking for the perceived identity of the person. We cannot automatically suppose that the labels equal Roma and/or resande, and therefore we use the terms "zigenare" and "tattare" in this article, as they are used in the historical sources (cf. e.g. Ericsson 2015, Montesino 2002: 12, Ohlsson al Fakir 2015, Pulma (ed.) 2015, Tervonen 2010). This may, however, be a sensitive issue, and therefore we want to clarify that we do this mainly to discuss how these labels were used by scholars and the majority of the society, not to discuss people per se who were labelled as such.

\section{Following a Label from the Department of Dialectology, Onomastics and Folklore Research to a Monitoring Census and Back}

In 1942, Carl-Martin Bergstrand published the book Tattarplågan (our translation "The 'tattare' plague", see fig. 3). This book was one expression of a long-term societal interest in itinerant groups such as "tattare". Bergstrand based the book on folklore accounts, collected by the archive for fifteen years, using a questionnaire on "tattare" (a subject to which we will soon return). 


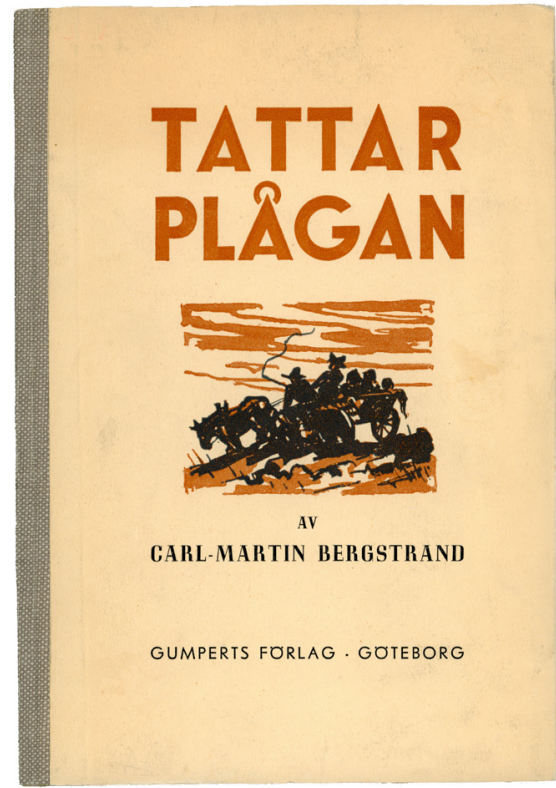

Fig. 3 The title page of Carl-Martin Bergstrand's Tattarplågan from 1942.

This title was one of Bergstrand's contributions to an ongoing public political debate referred to as the "tattare question". Topics discussed in the book are: "The 'Tattare' Problem through History", "Occupations and Means of Earning a Living", "Witchcraft", "Morality" and "Social Measurements" (often violent interventions by locals against "tattare" families). In the chapters, Bergstrand describes the content of the narratives connected to each theme, but also adds comments about them. The material on local interventions is described as "anything but edifying" and "shocking" (1942: 108). In other parts of the text he describes widely spread stereotypes of "tattare" without comment.

This public political debate was active with varying intensity between 1880 and 1955 and contained several discussions on what kind of political measures the government should take against families defined by others as "tattare". It became more intense during the 1920s and 1930s when a "tattarefication" process occurred; i.e. more and more people were defined by others as being "tattare" (Ericsson 2015, Johansen 1990). The debate contained discussions on race issues, and societal interventions such as sterilization were suggested as a means to prevent the group from growing any larger (de los Reyes 2013a, 2013b (see Archives), Ericsson 2015, Svensson 1993: 34-35, Tydén 2000: 63, Vitboken 2014).

These families also experienced a so-called politics of "territorial exclusion". Municipalities took measures to prevent "tattare" from settling in the area, for example by buying houses that families intended to move into or fining citizens 
who were in contact with members of the group (Ericsson 2012, 2015, 2017: 38). Many children and juveniles from "tattare" families were separated from their parents and detained at closed institutions such as orphanages or placed in foster families (SOU 2011: 61). These interventions had the purpose of turning the children into "Swedes". As we can see in Bergstrand's publication, this political debate also made an impact in a folklore archive context and the folklore researcher himself took an active part in the debate. After having collected accounts for over a decade, Bergstrand then also initiated a large-scale initiative involving the Nordic Museum to collect more accounts on "tattare".

\section{The Collections}

The collections contain rather extensive material of various kinds concerning people defined as "tattare". It was collected mainly during the first years of the 1940s on the initiative of Carl-Martin Bergstrand. In order to understand the formative process of the collection, Bergstrand's correspondence with colleagues at other folklore archives, local experts and collectors has been of great value to us. This reveals that Bergstrand was the primus motor behind initiatives concerning collecting material about "tattare" for folklore archives in Sweden. A substantial part of the material in Gothenburg is the result of questions formulated in a questionnaire on "tattare" used for many years by Bergstrand, and subsequently, after being edited, it was also used by the Nordic Museum, which distributed the questionnaire on "Tattare" in 1942 (Nm 78, we will soon return to this process). Bergstrand continued to use this questionnaire and also distributed an edited version that focused on a specific settlement in the western part of Sweden "The 'tattare' colony at Mjäla mo" 1947 (our translation).

The questions asked are strikingly leading and were directed toward the majority population. They are in many respects based on widely-spread stereotypes of "tattare" and composed to confirm earlier assumptions rather than to contradict them; the main goal seems to have been to accumulate more and more accounts on the same topic. For example, one question was about what abilities were associated with "tattare" (Nm 78:1-2, our translation):

What are the supposed typical characteristics of "tattare"? Do you know any concrete examples of their hot temper, violence, cunning, dishonesty, cowardice, lasciviousness, uncleanliness, immorality, mendacity, work-shyness, laziness, unwillingness to stay in the same place etc.? 
As a result, these folklore accounts mainly concern narratives filtered through the gaze of the majority. The descriptions are often imbued with an antigypsyist perspective, but there are also narratives that portray "tattare" in a more positive light, although from an outsider's perspective. All in all this is a very ambivalent, not to say difficult, material, due to its complex nature, meaning that it is both informative concerning specific ethnographic details about living conditions and everyday life at the same time as it can be deeply racist. ${ }^{5}$ These descriptions sometimes contain information of cultural historical interest such as craft-making, horse trade, clothing or transportation. Quite often the narratives are about named families, or one member of a family and these stories effectively divide the population into "us" and "them". There are also narratives about municipalities expropriating land to prevent a family from living there, of violence-sometimes lethal-affecting men, and brutal sexual violence, such as rape, against women. A frequent motif concerns childbirth on the road and involves the quest for shelter. The portrayed women are sometimes described as supernaturally strong and efficient in giving birth at night, sometimes with the aid of black magic, and being back on the road again the following morning. In these narratives, there are several intertextual references to biblical stories about the birth of Christ. There are also legends with extraordinary motifs, such as sorcery, that also occur in legends about different "othered" groups in Swedish society: e.g. Finns, Sámis and Freemasons. Quite often, legend motifs are presented in the form of a generalized personal experience narrative, i.e. a story narrated in the first person as something personally experienced. Some of the accounts are a result of a competition on the theme "Crime and punishment" announced by the Gothenburg archive in a local newspaper in 1942. To some extent, the theme probably guided the orientation of the narratives that were sent in as a response.

As a whole, the collection hosts stories mainly narrated from the majority's point of view. Besides folklore accounts, the collected material comprises newspaper articles, papers, and correspondence between collectors and the archive. Bergstrand compiled several albums with newspaper articles on "tattare" published in the Swedish press between 1942 and 1956. These media texts are about subjects such as crime and punishment, domestic and public violence, robberies and theft. The albums also contain several articles on "tattare" published by Bergstrand himself and some examples of academic debates concerning questions of how to collect and interpret folk memory material (see Skott 2016).

The archival researcher Kathryn Burns has described the archive as a chessboard (Burns 2010). In order to use it, you have to know how to move around. The most successful way to access folklore accounts on "tattare" in the Gothenburg archive has proven to be through its card catalogue as it is organized by theme. The collections are, as a whole, structured in number series; that is, 
the accounts are spread all over the archive and hard to find without the card catalogue as a registry. The card catalogue encompasses nearly 660 cards on "tattare", often with the heading "the population" (our translation), which was Bergstrand's euphemism for the category. These lead the way to 366 items containing everything from one to a hundred handwritten pages with a total of 1,800 pages. More than one card can point to the same account but to different pages. The first folklore account on "tattare" is from 1921 and the last from the end of the 1960s, but the main bulk of material was collected, around the year 1942. At the beginning of the 1940s, it is possible to detect a dramatically increasing number of records of accounts concerning "tattare" in the collection (see fig. 4). The accounts on "tattare" increase simultaneously as accounts on other topics decrease during these years. In other words, we can see an increased interest in this kind of material, but if you compare it with the whole collection, it constitutes quite a small part since the collection contains over a million accounts from western Sweden. There is most certainly a lot more material on "tattare" in the archive that is not mentioned in the card catalogue, but since the catalogue is a creation of Bergstrand, it constitutes a well-defined boundary.

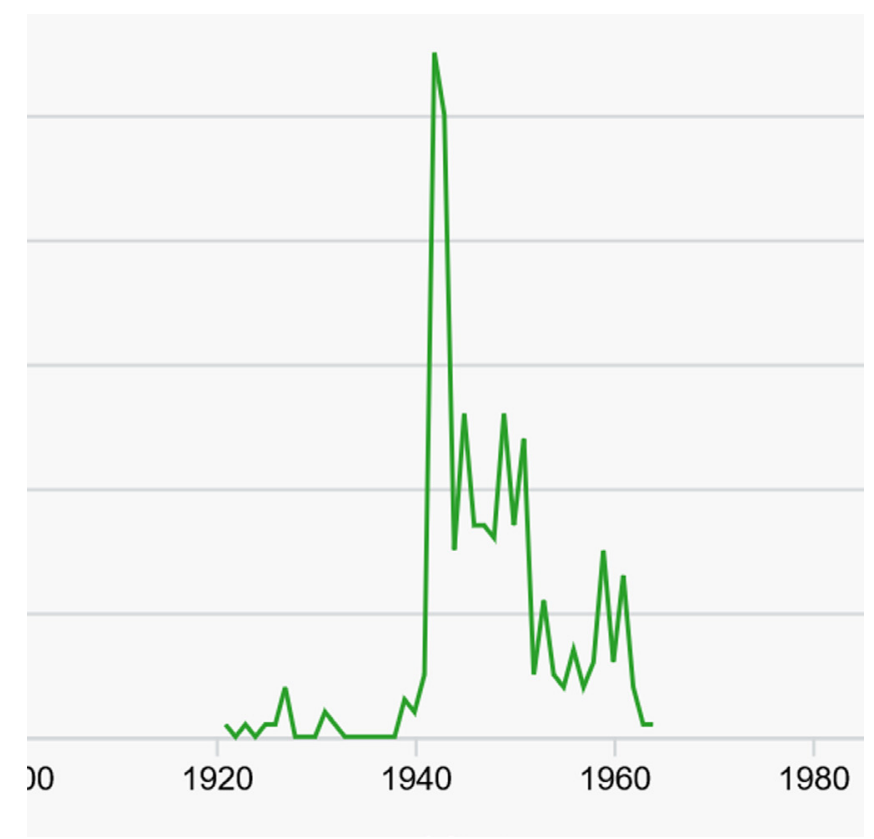

Fig 4. This diagram illustrates when and how much material about "tattare" wasregistered by West Swedish Folklore Archive over time. In order to produce this illustration, every account number, place of the narrator and page in the account where "tattare" is mentioned had to be entered into an Excel file and then further processed. Diagram made by Trausti Dagsson and research made by Charlotte Hyltén-Cavallius. 
Why was Bergstrand interested in the category of "tattare"? What were his driving forces? To us it seems that Bergstrand's research interest in the topic of "tattare" developed slowly from the early 1930s onward. For example, in the investigation of protocols from episcopal visits and parish meetings from the province of Västergötland in the eighteenth century, he touched upon the subject (Bergstrand 1933-1935). Most likely the category caught his eye through his other research on activities and groups that somehow deviate from the norm of society. Bergstrand published several articles on topics like murder, horse-slaughter (an assignment for the Atlas of Swedish Folk Culture managed by the ethnology professor Sigurd Erixon), criminality, alcohol use and alcoholism (e.g. 1932, 1959). In a letter to a local police officer, Sigurd Pira, Bergstrand mentioned that through topics such as "horse-slaughter, castration of pets, animal diseases, healing, black magic, thieves, robbers and manslaughter, proposals and weddings etc.", we also get to learn a lot about "tattare" (our translation). ${ }^{6}$ The contact between a local police officer and a manager at a folklore archive is explained in a letter to the Nordic Museum where Bergstrand described Pira as "a gentleman who has been studying the 'tattare' question for a long period and is one of our leading experts on 'tattare"' (our translation).?

\section{The Questionnaire Method}

The large-scale collecting was of course not formed in a vacuum. Bergstrand's book Tattarplagan was a contribution to the public political debate on the "tattare question". Over a decade before Bergstrand's initiative, one can detect an increasing interest in collecting material about "tattare" in other Swedish folklore archives. This growing interest could be seen, for instance, in some of the questionnaires distributed by the folklore archive in Uppsala during the late 1920s and 1930s. ${ }^{8}$ The questionnaire method has been used to varying extents by many of the folklore and folklife archives in the Nordic and the Baltic countries from the early twentieth century, a method that is still in use, although with several modifications (see e.g. Harvilahti et al. 2018, Lilja 2003: 33). The archives had collectors, men and women, all over the country that were engaged to compile answers to the many questions posed in the thematic questionnaires based on information solicited from local informants (Klein 2007: 120, Lilja 2003: 33). The collectors were paid, often an amount per every filed page. At the beginning, the questionnaires were long and detailed, five to fifteen pages, with tightly worded questions. One can see questionnaires as a specific genre of writing, influenced by the perspectives of diffusion and cultural borders that dominated this period (Klein 2007, Resløkken 2018, Richette 2003: 119, 128). 
In these early questionnaires distributed from the Uppsala archive, there is often one question out of a hundred others that is about "tattare". In the questionnaire "Trade and life on the road", distributed in 1927, for instance, the archive asked (our translation): "Did 'tattare' visit the village, and what does this word mean and which other words were commonly used, such as [...]?", and then follow several examples of different expressions of the category in Swedish dialects, e.g. skojare, fusse, fant. ${ }^{9}$ In another questionnaire, "Magic gestures, signs, numbers and colours" from 1934, the archive asked whether protective signs were used as a defence against persons perceived as being particularly dangerous, such as "those skilled in magic, whores, 'zigenare', 'tattare', Sámis and Finns" (our translation). ${ }^{10}$ One answer from the province of Lappland said that it was common to throw firebrands at individuals who were about to perform divination, for instance "tattare". ${ }^{11}$ A legend competition in the daily newspaper Aftonbladet in 1935 also generated material for the archive. ${ }^{12}$

However, answers to a questionnaire often contain extra information, and are not merely responses to questions posed by a dominant institution (cf. Nilsson 2003). The answers and questions could instead be seen as a dialogic relation that also involves intertextual references and a third party which the story or utterance actually is about, "the hero" or as in this case, "the other" (cf. Bachtin 1991, Nilsson 2003: 112). In fact, as Barbro Klein wrote, many of the answers are often "astonishingly lively, personal and even iconoclastic", and as she says, "they are no dry echoes of the questionnaires" (2007: 123).

As a result, by using the questionnaire method the archives acquired material and stories about "tattare", their everyday life, trade, handicraft and presumed sorcery without even asking specifically for it. Answers to questionnaires such as "Rickets", "Knackers and their work" and "The evil eye" contain such information. ${ }^{13}$ For instance, women who were defined as "tattare" were described as cunning folk that were able to cure rickets. ${ }^{14}$ In other accounts, "tattare" were said to have the evil eye or to be able to put a spell on cattle. ${ }^{15}$

\section{Unpacking the Questionnaire: Tattare Nm 78}

As mentioned above, we believe that Bergstrand was the primus motor behind initiatives concerning collecting material about "tattare" in folklore archives. In June 1942, the Nordic Museum distributed the "tattare" questionnaire, Nm 78, signed by co-workers at the department of ethnological research, Mats Rehnberg and Sven Andersson, to collectors in different parts of Sweden. Taking the signatures literally, you could get the impression that it was the researchers at the Nordic Museum-Rehnberg and Andersson-who compiled the questionnaire. A collection of letters at the Gothenburg archive suggests that it was instead an initiative from Bergstrand and that this questionnaire was a re-edited version of Bergstrand's own. ${ }^{16}$ 
In the introduction, the questionnaire $\mathrm{Nm} 78$ states that in almost every village in Sweden, people have to a greater or lesser extent made the acquaintance of people known as "tattare". Therefore, it is said, the folklife department would like to collect material that could shed light on their way of life. The introduction is followed by five tightly written pages with questions covering topics such as: name-calling or ethnic slurs; appearance, such as "dark" or "white"; presumed characteristic traits, such as laziness, thieving and dishonesty; housing, migration, language, sorcery, divining, professions, musical abilities, trade and craft; and, finally, forms of begging and family constellations. By judging the questions, the Nordic Museum was primarily interested in confirming already known prejudiced preconceptions of the category, presenting several examples of answers to the questions and lots of background information based on already existing accounts.

The correspondence between the Nordic Museum and Bergstrand reveals that he first used a test version of the questionnaire, and also instructed collectors working for the archive to use it for a period of time, but that he was anxious to collect more material. ${ }^{17} \mathrm{He}$ then contacted the Nordic Museum to investigate their interest in the topic. After a positive response, he also sent the questionnaire for comment to the local police officer Sigurd Pira, and received several suggestions on how to develop it. ${ }^{18}$ Pira also published his own article on "tattare" in the police officers' magazine (1942). After a couple of months of revising, sending the questionnaire back and forth, the questionnaire was complete in June 1942. Since Mats Rehnberg was in the military, Associate Professor John Granlund, also at the research department at the Nordic Museum, served as an intermediary between him and Bergstrand.${ }^{19}$ Bergstrand was eager to have the questionnaire ready by the summer since he was planning fieldwork, visiting priests and examining parish registries for information on "tattare". He also suggested that the Nordic Museum should contact the folklore archives in Uppsala and Lund to persuade them to distribute the questionnaire on "tattare".

When Bergstrand in the late 1940s evaluated the process of making the questionnaire in collaboration with the Nordic Museum, he expressed dissatisfaction in correspondence with his friend and ally Carl-Herman Tillhagen. $\mathrm{He}$ felt that the questionnaire he had composed and used for several years had undergone a "thorough re-editing process" and become more "unwieldy" rather than easy to use (our translation). ${ }^{20}$ So, as we have seen, besides the folklorists and ethnologists at the archives, a police officer was also involved in shaping the questionnaire. 


\section{Interrelations between the Monitoring Power and Folklore Archives}

At the same time as the formation and distribution of the questionnaire, which rendered a good response with 135 answers, the National Board of Health and Welfare (the Board) was commissioned to make a census, or "inventory" as they called it, of all "tattare" and "zigenare" living in the country. The results on "tattare" were published in 1945 ("Tattarnas antal och levnadsförhållanden" 1945). The decision to perform this census was based on several petitions to the government on social problems and inconveniences that were seen as caused by "tattare" due to their way of living. From reading the results of the census made by the Board and going through correspondence in the archives, it appears that the government agency had drawn on the folklore accounts and the written answers to the questionnaire on "tattare" (see also Westin et al. 2014: 197-198). ${ }^{21}$

During the preparations, the Board distributed the census forms for evaluation to folklife and folklore scholars, including Sigurd Erixon, Mats Rehnberg and Carl-Martin Bergstrand, as well as to other researchers and archives involved in the "tattare" question, such as Nils Holmberg at the Regional State Archives in Gothenburg and Manne Ohlander, manager and teacher of remedial classes in Gothenburg, who performed intelligence tests on children labelled as "tattare".2 From this point on, the connection between the archives and the Board was established and the relationship would continue to develop. Information would be shared and the archives would review the census methods and identify possible pitfalls. The correspondence shows that Bergstrand was actively engaged in the preparations. He shared his information, he shared folklore accounts and, even when serving in the military, he communicated with the Board. ${ }^{23}$ When the Nordic Museum described in an information pamphlet its involvement in the census, it proudly stated that (Meddelanden från Etnologiska undersökningen 1943, our translation):

In our last number, we were able to report that a questionnaire concerning "tattare" was completed. We are now obliged to announce that the ongoing governmental investigation on this group has already used our material. It is very gratifying that our folklife research can be of immediate use to society.

In a note attached to the questionnaire, Sven Andersson, head of the census, describes their method to the scholars. The police force would approach people familiar with the area to be able to establish who should be defined as "tattare", and informants would consist of representatives of the poor relief, child welfare and school boards in the municipalities, along with individuals familiar with 
local traditions. For the latter category, the Board would receive lists of people engaged by the folklore archives as collectors. That is, the census did not start with a definition of who should be regarded as "tattare", but would rely on widely spread and established notions reported by people familiar with the area and local traditions.

In his correspondence with the Board, Bergstrand expressed his profound interest in the question and emphasized that they needed to cooperate with the archive in order to become efficient. He demonstrated his specific competence and long experience by telling about the rich collection of the archive regarding information about "tattare", as well as folklore accounts and transcripts from parish registries, poor relief books etc., and by displaying his acquaintance with less familiar surnames within the category, living areas, migration patterns and professions, such as rag-and-bone man and knife grinder. He also mentioned that he had excerpts from the parish registries concerning several families "of which not even the priests or the police etc. are aware that they are 'tattare"' (our translation), and concluded that it was important that the census forms found their way to the right people with both an interest in, and knowledge about, the population. ${ }^{24}$

During the autumn of 1943, the West Swedish Folklore Archive and the Nordic Museum provided the Board with information on names and addresses of individuals who were considered reliable and should be contacted by the census workers-people who were already hired as collectors. ${ }^{25}$ These lists also contain information about local folklore societies in the area. The purpose was to connect the census workers with "trustworthy informants", people who were familiar with local tradition. In the instructions accompanying the census form, it said that general judgements concerning appearance, ways of living etc. were not enough information in order to decide whether a person was a "tattare" or not. Primarily, the census workers should go through notes in the parish books, column 2. But since people who were perceived of according to local tradition as being "tattare", were not always registered in the parish book, the census workers were told to also register people who were considered to be of "tattare descent" by one or more "trustworthy informants". ${ }^{26}$ As mentioned before, it was the folklore archives who were the guarantors that these informants were "trustworthy". It was emphasized that even diligent families that contributed to society should be registered; the purpose of the census was to register all people that were thought to belong to the category. What the people labelled as "tattare" thought did not seem to be of interest to the census. The Nordic Museum also provided the Board with a registry of surnames that appeared in the answers relating to their questionnaire and were considered to be names of "tattare families". ${ }^{27}$ On several occasions, both archives provided the Board with folklore accounts from their collections to use in their report. ${ }^{28}$ 
The relations and connections between the institutions and the exchange of information show that the folklore archives including the Nordic Museum were, in a most fundamental and coherent way, co-creators of the national census on "tattare" performed by the Board. They were, in an initial stage, given possibilities to give feedback on the census forms, they provided the Board with information of names and addresses of persons who were considered trustworthy and familiar with local tradition, and they sent folklore accounts from their collections on several occasions for the Board to use in their work. It was also the informants' knowledge about local traditions that constituted the definition of "tattare" used by the Board in the census. One could therefore say that, in effect, the work performed by the folklore archives constituted the first step in the national census made by the National Board of Health and Welfare, even though it was not the initial purpose for the archives (cf. Westin et al. 2014: 199). The information exchange also went in the other direction; when the Board asked the West Swedish Folklore Archive for material, they enclosed a registry of "tattare households" in the province of Värmland that had been registered during the autumn. ${ }^{29}$

In this part of the article, we have tried to unfold the network of positions and actors active in the formation, and the agency of the label and category of "tattare" in the folklore archive by looking more closely at the collections in Gothenburg and at the creation of the questionnaire on "tattare" distributed by the archives in 1942. We have also followed the label from the archive to a monitoring census and back. As we have seen, not only folklore archives, but also the police force, took part in this formulating process. Results from the questionnaire, but also older folklore accounts, were then connected to the monitoring actions of a government agency. In doing this unfolding and following, we wanted to highlight the political and monitoring dimensions of archival practices in relation to a minority group in Sweden.

\section{Defining a Minority: Following Tillhagen from the Nordic Museum to a Monitoring Census and Further}

In 1943, the Nordic Museum started to conduct ethnological fieldwork to increase knowledge about the culture of the Swedish "zigenare" (Tillhagen 1965: 89). The work was carried out by the folklorist Carl-Herman Tillhagen (1906-2002), who at the end of 1943 sought cooperation with the coppersmith Johan Dimitri Taikon in Stockholm (Tillhagen 1946: 5-6, 1994: 251), a prominent man who was sometimes called the "gypsy chief" even, probably somewhat jokingly, by his own family (Lundgren \& Dimiter Taikon 1998). Besides many other areas of interest, Tillhagen thereafter worked with questions regarding "zigenare" in Sweden until his retirement in 1972. His collection of material called Sveriges 


\section{Culture Unbound}

Journal of Current Cultural Research

zigenare ("Zigenare of Sweden") at the Nordic Museum is extensive, consisting of approximately 45 volumes, including machine- and handwritten documentation notes, letters, photographs and newspaper cuttings, as well as the folk tale material that Tillhagen documented with Taikon as his storyteller, of which some tales were edited and published in a book in 1946 (see fig. 5).

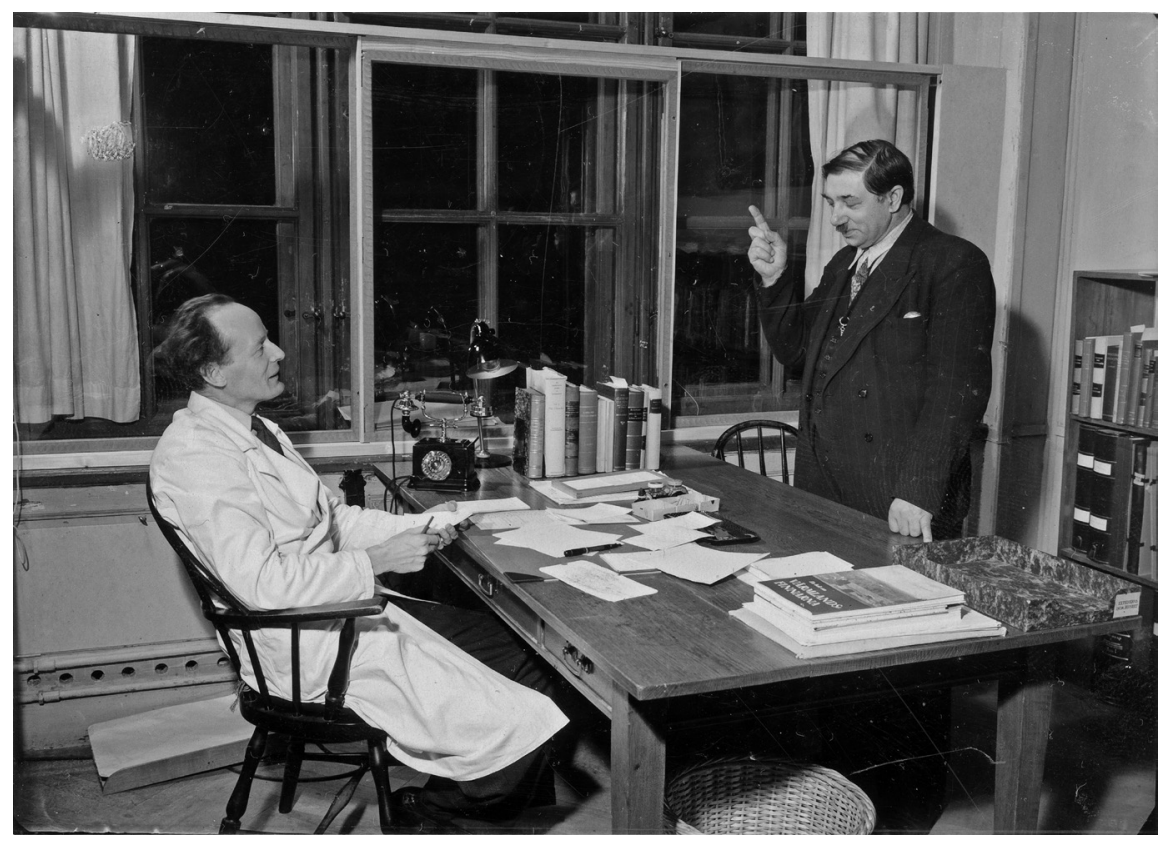

Fig. 5. Carl-Herman Tillhagen and Johan Dimitri Taikon at Tillhagen's office at the Nordic Museum 1947. The information accompanying the photograph says (our translation) "Johan Dimitri Taikon tells tales". Looking closely at the desk in front of Tillhagen, the papers and notes resemble the material in the volumes that comprise the archival remains of their collaboration (vol. $43 a-g$ of the collection Sveriges zigenare). Photo: The Nordic Museum.

Tillhagen worked with Taikon until Taikon's death in 1950. When Tillhagen sought Taikon to become his informant, they struck a deal: Taikon would become Tillhagen's informant and Tillhagen would help Taikon put together a dictionary of Kelderash Romani, since Taikon was worried that it would soon be forgotten (Tillhagen 1947: 90-91). Another early source of information for Tillhagen and the museum was the questionnaire Zigenare, Nm 135, which was sent out in 1946 on Tillhagen's initiative and received 94 answers. However, Tillhagen's greatest continuous interest throughout most of his career seems to have been the genealogy of "zigenare" in Sweden. 
In 1949-1950, Tillhagen published a genealogy of "zigenare" in Sweden in the international Journal of the Gypsy Lore Society. He thought that the above-mentioned 1943 census of "zigenare" had not included all "zigenare", and therefore he made another genealogy (Tillhagen 1949a: 2). He did this from the 1943 census of "zigenare" and with the help of Taikon, although he went to great lengths to check and verify the information Taikon had given him (Tillhagen 1949a: 3). It must be mentioned that Taikon probably shared this interest in genealogy but could not foresee how the registry that Tillhagen made would later be used as a basis for several additional state and municipality interventions. The notes for Tillhagen's registry, as well as later updated versions, are kept in the Nordic Museum Archive. They are full of handwritten jottings, apparently made at many different times; there are crossed-over names for people who died, added names for newborns, names of new spouses, etc. that Tillhagen had learned about over time. ${ }^{30}$ From this, it can easily be noted that this particular interest continued throughout his career. However, to understand the impact of this interest, we have to follow the traces of his activities outside this archive.

In 1952, "zigenare" in Sweden were recognized as Swedish citizens, and in 1954, the Aliens Act of 1914 was abolished (e.g. Fernstål \& Hyltén-Cavallius (eds) 2018a: 22-23). In 1954-1956, a state investigation was carried out by the National Board of Health and Welfare regarding the situation of the "zigenare", most of whom were still nomadic or, if resident, living under quite poor housing conditions. The group was also quite poor overall, with difficulties finding work and a sustainable income, and a low education level. The clearly expressed goal of the investigation was assimilation. The investigation consisted of three appointed officials who were members of the second chamber of the parliament, a secretary from the department of health and a statistical expert, but they also needed someone with better knowledge of the people to be investigated. Therefore, Carl-Herman Tillhagen of the Nordic Museum was employed by the investigation as an "expert" (SOU 1956). By then, Tillhagen had about a decade of experience of working with "zigenare" and he had many personal acquaintances within the group (e.g. Tillhagen 1956: 87). He had also a few years earlier helped a group of members of the parliament with information regarding the situation of "zigenare" for their proposal for this investigation (Tillhagen 1994: 273). At the Nordic Museum, there is a proof-sheet of the proposal with proofreading notes by Tillhagen, showing that he did more than just initially help the members of the parliament with facts; the language and content of the proposal indicates that he actually wrote it. It is also interesting that an argument at the end of the proposal for the parliament to accept it is that the investigation would not need to be very time-consuming or costly, since it could, to a great extent, rely on the census of 1943 and the work done for several years by the Nordic Museum. ${ }^{31}$ 
A fundamental part of the investigation was, however, a new official census, or "inventory" as it was called by the investigators, which was carried out by local police officers on December 10 1954. On that day, they visited the majority of camps and houses where "zigenare" lived in all parts of Sweden. A few months later, in the winter of 1955, Tillhagen made additional visits for in-depth interviews. This was Tillhagen's main task in the investigation, in addition to checking the information that was gathered by the police (SOU 1956: 8-10). However, while following the traces of Tillhagen's activities from the Nordic Museum to the material from the investigation at the Swedish National Archives, it becomes clear that he also came to influence the investigation beyond these official tasks, since he was also helping out with questions that were added to the police form as well as proofreading and suggesting changes to the official report of the investigation. ${ }^{32}$

Of great importance, though, is that Tillhagen lent his registry, which had previously been published in Journal of the Gypsy Lore Society, to the investigators, presumably to be used as a basis for the upcoming census and as a comparison or control material. ${ }^{33}$ This was because the census of 1943 was not sufficient, according to Tillhagen (see above). In the in-depth interviews, Tillhagen seems to have been free to formulate the questionnaire on his own (at least there is no archival material indicating, for instance, a discussion regarding the content of the questionnaire) and was therefore given the power to gather the information he thought necessary as input for solving the so-called "zigenare question" (for this notion, see Montesino 2001). All in all, the archival materials show that Tillhagen's view of "zigenare" and of who belonged to the group greatly influenced the outcome of the investigation, i.e. the content of the report and its suggested solutions to the "zigenare question", and the new official census, based on, or at least verified against, Tillhagen's previous registry.

As discussed above, Tillhagen continuously updated his registry, and the archival materials at the Nordic Museum show that he was engaged in "zigenare" to a great extent over the years. At the end of the 1950s, he was once again engaged as an "expert", this time by the National Labour Market Board, and his registry came in handy again (Ohlsson al Fakir 2015: 125-126). Then, in 1960, the state launched a programme to help municipalities finance housing and schooling for "zigenare", as well as start-up loans. The National Labour Market Board informed authorities that, if concerned about who should be considered a "zigenare", they could consult the list of names from the 1954 census, (Staten och zigenarna 1960: 2). Also, in the large socio-medical study of "zigenare" 1962-1965, Tillhagen's existing registry was important as it facilitated the study "to a great extent" (Takman 1976: 31). The registry was also used at the later "Zigenarsektionen" ("the Gypsy Department", our translation,) in the City of Stockholm, where individual personal files were set up for each "zigenare" within the municipality. There, the 
registry was called "Summary of the gypsy clans in Sweden (investigation by Tillhagen)" (our translation), and it was probably used as a reference of who was who and related to whom. ${ }^{34}$

By following Tillhagen from his home institution at the Nordic Museum to the Swedish National Archives and his engagement in the investigation of "zigenare" 1954-1956, a greater understanding could be reached regarding his impact on the official formation of the category. With the help of his registry, established through his folkloristic work at the National Museum, an official census was carried out, which later came to be reused in several different official contexts. His work contributed to establishing the official boundary lines for who was to be regarded as "zigenare". It should be noted that by then there was a larger correlation between the use of the word "zigenare" by officials and Roma than between people labelled "tattare" and how they identified, or not identified, as resande. As discussed above, people used the word "zigenare" about themselves in Swedish, and rom in Romani. Nevertheless, through Tillhagen's registry and the census of 1956-1956, the boundary of the group became officially established. And as shown, it could also be used as a tool for control, for example by "Zigenarsektionen" in Stockholm, and through economic assistance-if identifying as a "zigenare"/rom while not on the list, one did not have the right to support.

\section{Discussion}

As the reader will probably have noticed, several of the interventions regarding "tattare" and "zigenare" in Sweden have coincided with major historical events. The new Aliens Act of 1914 prohibiting foreign "zigenare" from entering Sweden was introduced the same year as World War I broke out in Europe, causing travelling "zigenare" already in Sweden to stay within the borders and the labels "tattare" and "zigenare" to become firmly separated from each other.

In 1943, the state took a census of "tattare" and "zigenare" in Sweden. This was during World War II, which no one at the time knew how or when it would end, with neighbouring countries being occupied by Germany. In 1942, Bergstrand had published Tattarplagan, a contribution to the public debate referred to as the "tattare question", which contained discussions of what kind of political measures the government should take against families defined by others as "tattare". The publication is ambivalent since Bergstrand also expressed a dislike of stories about violence against families and thought that "not all ["tattare" were] morally lower standing or immune to religious impact" (1942: 135, our translation). As shown above, he and other representatives of the folklife field were also deeply involved in the census. During the time, there was a public political debate and research going on regarding how to dispose of unwanted segments of society; a discussion 
that included arguments for sterilization (e.g. de los Reyes 2013a, 2013b (see Archives), Svensson 1993: 34-35, Tydén 2000: 63). To a later observer of these events, Bergstrand's involvement in the "tattare question" at the time may seem damning. We have not, however, found any indication in the archival material that he had any Nazi sympathies. Rather, he was probably just a man of his time who had a long-lasting interest in marginal groups such as "tattare", and had a similar desire to be of use to society as that which the Nordic Museum expressed in 1943: "It is very gratifying, that our folklife research can be of immediate use to society" (Meddelanden från Etnologiska undersökningen 1943, our translation).

In 1943, the Nordic Museum also began ethnological fieldwork to gain more knowledge about "zigenare" in Sweden: a projectthat Tillhagen was involved in. As shown above, Tillhagen was engaged in research about "zigenare" and also had private engagements during his whole career. Being involved in the post-war investigation, including a census of "zigenare" 1954-1956, he gives a somewhat more humane impression than Bergstrand. This was a time of social engineering and building the "folkhem", or "the people's home", signifying the welfare state. In the official report of the investigation it is clear that the point of departure as well as the conclusion was that "zigenare" must be included in this societal project, and the focus was on permanent housing and education (SOU 1956). In Tillhagen's eagerness to help "zigenare" access housing and education and to be of use to society by making "zigenare" part of the "folkhem" and be useful citizens (Fernstål \& Hyltén-Cavallius 2019), he also thought that in this assimilation process the culture of "zigenare" had to be sacrificed and that it would be lost, and that "zigenare" as a group eventually would disappear (SOU 1956: 112-113).

The extensive materials concerning "tattare" and "zigenare" in the folklore archives where Bergstrand and Tillhagen worked reveal that they took a keen interest in these categories. These materials can be of great interest from many different perspectives, and we could have stopped there, at "just" using the materials for information and pointing out Bergstrand's and Tillhagen's great and long-term interest. However, by unfolding the networks of Bergstrand and Tillhagen and following the traces of their work to other archives, we were able to highlight some of the political and monitoring dimensions of archival practices in relation to these categories. We have seen that Bergstrand and Tillhagen functioned as "experts" and as such had great influence on politics and interventions regarding so-called "tattare" and "zigenare" and, as folklore scholars who built their knowledge on established methods, their positions were not questioned. For a scholar today, leaving the single archive requires more work but may in return enable a deeper contextual understanding of a subject. 
Recognizing the power of archival collections and the contexts in which they were created, as well as how they were used and which actors were involved in the collecting and use of the archives, enables us to gain a deeper understanding of collections that may comprise sensitive and even offensive material. By choosing methods of research that place them in a wider societal context, this can be deepened even further. Through this understanding, these collections can be used for further research today, even though they largely seem outdated.

Charlotte Hyltén-Cavallius is a researcher at the Institute for Language and Folklore in Sweden. She is an ethnologist and associate professor in Minority Studies at Åbo Akademi University, Finland and engaged in minority studies and critical heritage studies. Email: charlotte.hylten-cavallius@isof.se

Lotta Fernstål is a researcher at the National Historical Museums in Sweden. She is an archaeologist and engaged in critical heritage studies.Email: Lotta.Fernstal@ shm.se

Their most recent publications are about Roma in Sweden and Finland, Romska liv och platser. Berättelser om att leva och överleva i 1900-talets Sverige (eds. 2018) and Undersökning om de så kallade tattare eller zigeuner, cingari, bohemiens: deras härkomst lefnadsätt, språk mm. A recent article (2019) in ARV. Nordic Yearbook of Folklore is "To stage a minority group-the folklorist Carl-Herman Tillhagen and the photographs in the collection Sweden's gypsies at the Nordic Museum".

\section{Notes}

1 This article is part of our project "Antigypsyism and the collections - knowledge production and collecting at cultural history museums and archives in the twentieth century", financed by the Swedish Arts Council and the Swedish National Heritage Board. Thanks to the two anonymous peer reviewers, Susanne Nylund Skog, Fredrik Skott, the co-authors of this issue and the higher seminar in ethnology at Uppsala University for constructive comments on earlier versions of this article.

2 This is our overall impression from reading Bergstrands communication with other researchers and archives, Serie E:5 correspondence 1930-1939 and 1940-1949, Department of Dialectology, Onomastics and Folklore Research, Gothenburg, (DAG).

3 The document "C.H. Tillhagen C.V.", Carl-Herman Tillhagen, vol. 1, the Nordic Museum archive.

4 Census forms, Inventering av zigenare och tattare 1943-1944, vol. H10:7, the Swedish National Archives.

5 This is based on our overall impression from reading an extensive number of accounts, e.g. vff2384, vff2212 and 2213, ifgh6500, vff283, vff612, vff1095, vff1970 
vff2378, vff2230, vff2247, vff2224, vff2229, ifgh826, ifgh874, ifgh3562, ifgh4323, ifgh4333, ifgh4458, ifgh4526, ifgh4547, ifgh4680, ifgh4713, ifgh4723, Institute for Language and Folklore, Department of Dialectology, Onomastics and Folklore Research, Gothenburg.

6 Letter to Sigurd Pira from C.-M. Bergstrand 18/5 1942, Institute for Language and Folklore, Department of Dialectology, Onomastics and Folklore Research, Gothenburg.

7 Letter to John Granlund from C.-M. Bergstrand 29/5 1942, Institute for Language and Folklore, Department of Dialectology, Onomastics and Folklore Research, Gothenburg.

8 For an early example of questionnaires mentioning "tattare", see e.g. "Trade and life on the road" (T11) distributed in 1927. Institute for Language and Folklore, Department of Dialectology and Folklore Research, Uppsala.

9 T11, page 5, Institute for Language and Folklore, Department of Dialectology and Folklore Research, Uppsala.

10 M90, page 7, Institute for Language and Folklore, Department of Dialectology and Folklore Research, Uppsala.

11 ULMA 16259, Institute for Language and Folklore, Department of Dialectology and Folklore Research, Uppsala.

12 E.g. ULMA 23575:89, page 15-16, Institute for language and folklore, Department of Dialectology and Folklore Research, Uppsala.

13 K23 1939, M131 1937, M11 1932, Institute for Language and Folklore, Department of Dialectology and Folklore Research, Uppsala. The questionnaire M131 was a cooperation between the archives in Gothenburg and Uppsala (see Skott 2008: 151-153).

14 E.g. ULMA 13003, 13689, 13799, Institute for Language and Folklore, Department of Dialectology and Folklore Research, Uppsala.

15 E.g. ULMA 5427, 5305, Institute for Language and Folklore, Department of Dialectology and Folklore Research, Uppsala.

16 This is based on correspondence between Bergstrand and Rehnberg and Granlund, both at the Nordic Museum, 22/1, 30/4, 18/5, 28/5, 29/5, 6/6 1942 and 11/1 1943, E:5 correspondence 1940-1949, DAG.

17 Letter to Sigurd Pira from C.-M. Bergstrand 13/5 1942, Institute for Language and Folklore, Department of Dialectology, Onomastics and Folklore Research, Gothenburg.

18 Letters to Sigurd Pira from C.-M. Bergstrand 13/5 and 18/5 1942; letter to C.-M. Bergstrand from Sigurd Pira 15/5 1942, Institute for Language and Folklore, Department of Dialectology, Onomastics and Folklore Research, Gothenburg.

19 Letters to John Granlund from C.-M. Bergstrand 30/4 1942, 18/5 1942, 29/5 1942; letter to C.-M. Bergstrand from John Granlund 28/5 1942, Institute for Language and Folklore, Department of Dialectology, Onomastics and Folklore Research, Gothenburg. 


\section{Culture Unbound}

Journal of Current Cultural Research

20 Letter to C-H Tillhagen from C.-M. Bergstrand 16/11 1948, Institute for Language and Folklore, Department of Dialectology, Onomastics and Folklore Research, Gothenburg.

21 Letter to Bergstrand from Andersson 10/9 1943, correspondence 1940-1949, DAG.

22 Letters from Sven Andersson to Sigurd Erixon, C.-M. Bergstrand, Mats Rehnberg 23/7 1943, the Swedish National Archives, National Board of Health and Welfare, vol H10:06. Axelsson 2013, the Government Offices archives. See also Axelsson 2007.

23 Letter to Sven Andersson from C.-M. Bergstrand 17/7 1943, the Swedish National Archives, National Board of Health and Welfare, vol H10:06.

24 Letter to Sven Andersson from C.-M. Bergstrand 27/7 1943, the Swedish National Archives, National Board of Health and Welfare, vol H10:06.

25 The document "Förteckning, Personer, vilka av Nordiska museet och Västsvenska folkminnesarkivet $m$.fl. föreslagits böra anlitas såsom sagesmän vid socialstyrelsens tattarinventering i Värmlands län”; letter to C.-M. Bergstrand from Sven Andersson 10/9 1943; letter to the National Board of Health and Welfare from C.-M. Bergstrand with a registry of informants for the county Värmland 13/9 1943, the Swedish National Archives, National Board of Health and Welfare, vol H10:06.

26 Instructions accompanying the census form about "tattare", the Swedish National Archives, National Board of Health and Welfare, ref. 968-969, 5th bureau, vol H10:06. 27 Undated registry of surnames frequent in answers of questionnaire Nm 78 Tattare that was sent out from the Nordic Museum, the Swedish National Archives, National Board of Health and Welfare, vol H10:06.

28 E.g. letter to Sven Andersson from Mats Rehnberg 7 /8 1943; letter to Etnologiska undersökningen at the Nordic Museum from Hugo Ljungström $7 / 3$ 1944; letter to Sven Andersson from C.-M. Bergstrand 13/9 1943, the Swedish National Archives, National Board of Health and Welfare, vol H10:06.

29 Letter to C.-M. Bergstrand from the National Board of Health and Welfare (not signed) 23/12 1943, the Swedish National Archives, National Board of Health and Welfare, vol H10:06. Letter to the Board from Bergstrand 27 december 1943.

30 See especially vol. 45a, Sveriges zigenare, the Nordic Museum Archive.

31 The document "Förslag till motion i Andra kammaren rörande en allsidig utredning rörande zigenarfrågan i Sverige. Stockholm den 22 januari 1953”, vol. 45g, Sveriges zigenare, the Nordic Museum Archive.

32 Letter from Tillhagen to Olof Särnmark 26/8 1954; manuscripts for the report Zigenarfrågan (SOU 1956), the Swedish National Archives, YK 1506, vol. 1 and 9.

33 Letter from Tillhagen to Olof Särnmark 26/8 1954, the Swedish National Archives, YK 1506, vol. 1.

34 Stockholm City Archives, SSA/1929, vol. D2b:1. Eriksson 2012: 41-42, the Government Offices archives. 


\title{
References
}

\author{
Archives
}

Government Offices Archives

\section{Studies ordered by the Government Offices for Den mörka och okända historien-Vitbok om övergrepp och kränkningar av romer under 1900-talet (2014)}

Axelsson, Thom (2013): Tattarna och begåvning: Manne Ohlanders intelligensundersökningar av tattare under 1940-talet, A2012/1804/DISK.

de los Reyes, Paulina (2013a): Ett olösligt problem: Rapport om steriliseringslagarnas konsekvenser för romer och resande, A2012/1901/DISK.

de los Reyes, Paulina (2013b): Romsk och resandetillhörighet i ansökningar om sterilisering i mitten av 1940-talet, A2013/1174/DISK.

Eriksson, Lena (2012): Zigenarsektionen i Stockholms stad 1958-1997, A2012/1448/ DISK.

Institute for Language and Folklore, Department of Dialectology,

Onomastics and Folklore Research, Gothenburg

Card catalogue, 659 cards on "tattare", Correspondence

Incoming and outgoing correspondence 1930-1939

Incoming and outgoing correspondence 1940-1949

Letter to C.-M. Bergstrand from Sigurd Pira, 15/5 1942.

Letter to C.-M. Bergstrand from Mats Rehnberg, 22/1 1942.

Letter to C.-M. Bergstrand from John Granlund, 28/5 1942.

Letter to C.-M. Bergstrand from Sven Andersson, 10/9 1943.

Letters to John Granlund from C.-M. Bergstrand, 30/4, 18/5, 29/5, 6/6 1942, 11/1 1943.

Letters to Sigurd Pira from C.-M. Bergstrand, 13/5, 18/5 1942.

Letter to C.-H Tillhagen from C.-M. Bergstrand, 16/11 1948.

Folklore accounts, vff2384, vff2212 och 2213, ifgh6500, vff283, vff612, vff1095, vff1970 vff2378, vff2230, vff2247, vff2224, vff2229, ifgh826, ifgh874, ifgh3562, ifgh4323, ifgh4333, ifgh4458, ifgh4526, ifgh4547, ifgh4680, ifgh4713, ifgh4723.

Questionnaires, Tattarkolonin på Mjäla mo, 1947 (C.-M. Bergstrand).

Institute for Language and Folklore, Department of Dialectology and Folklore Research, Uppsala

Card catalogue 103 cards on "tattare" and "zigenare".

Folklore accounts,ULMA 5305, ULMA 5427, ULMA 16259, ULMA13003, ULMA 13689, ULMA 13799, ULMA 23575:89. 


\section{Questionnaires}

T11 Handel och livet på färdvägar, 1927 (Lars Levander and Herman Geijer).

M11 Ont öga, ond tunga, hågsa, 1932 (Åke Campbell).

M90 Magiska gester, tecken, tal och färger, 1934 (Sven Liljeblad).

M100 Om kloka (trollkunniga och vismän), 1935 (Åke Campbell).

M131 Hästslaktaren och hans arbete, 1937 (Carl-Martin Bergstrand and Ingeborg Nordin-Grip).

K23 Engelska sjukan, 1939 (Johannes Ejdestam).

\section{The Nordic Museum Archive}

Carl-Herman Tillhagen, Vol. 1, C.H. Tillhagen C.V Sveriges zigenare Vol. 1-45; Vol. 45g; Förslag till motion i Andra kammaren rörande en allsidig utredning rörande zigenarfrågan i Sverige. Stockholm den 22 januari 1953

Questionnaires, the Nm series Nm 78 Tattare (1942, 135 answers); Nm 135 Zigenare (1946, 94 answers).

\section{Stockholm City Archives}

Zigenarsektionen, SSA/1929, Vol. D2b:1, Sammanställning över zigenarsläkterna i Sverige, (Undersökning av Tillhagen).

\section{The Swedish National Archives}

\section{Socialstyrelsen 5:e byråns arkiv 1913-1961. Inventering av zigenare och tattare 1943-1944}

Vol. H10:6, Tattareundersökningen, primärmaterial, uppgifter och tabeller ("skrivelser").

Förteckning, Personer, vilka av Nordiska museet och Västsvenska folkminnesarkivet m.fl. föreslagits böra anlitas såsom sagesmän vid socialstyrelsens tattarinventering i Värmlands län.

Förteckning, Personer, vilka av Nordiska museet föreslagits böra anlitas såsom sagesmän vid socialstyrelsens tattarinventering i Stockholms län.

Instructions accompanying the census form about "tattare", the Swedish National Archives, National Board of Health and Welfare, ref. 968-969.

Undated registry containing surnames frequent in answers to questionnaire $\mathrm{Nm} 78$ Tattare that was sent out from the Nordic Museum.

Letter to Sven Andersson from Mats Rehnberg, 7 /8 1943.

Letter to C.-M. Bergstrand from Sven Andersson, 10/9 1943, ref. 956.

Letter to C.-M. Bergstrand from the National Board of Health and Welfare (not signed), 23/12 1943 .

Letter to the National Board of Health and Welfare from C.-M. Bergstrand containing a registry of informants for the province of Värmland, 13/9 1943.

Letter to the National Board of Health and Welfare from C.-M. Bergstrand, 27/12 1943, dnr 1163.

Letter to Etnologiska undersökningen at the Nordic Museum from Hugo Ljungström, 17/3 1944.

Letter to Sigurd Erixon, C.-M. Bergstrand, and Mats Rehnberg from Sven Andersson, 23/7 1943, ref. V867-871.

Letter to C.-M. Bergstrand from Hugo Ljungström, 17/3 1944, dnr 131. 


\section{Culture Unbound}

Journal of Current Cultural Research

Letters to Sven Andersson from C.-M. Bergstrand, 17/7, 27/7, 13/9 1943.

Vol. H10:7, Tattareundersökningen, primärmaterial, inkomna uppgifter från år 1943

Census forms, filled out by local police 31/5 1943, with added notes from the investigators.

\section{4 års zigenarutredning, YK 1506}

Vol. 1, Letter from Carl-Herman Tillhagen to Olof Särnmark, 26/8 1954.

Vol. 3 Uppgifter till 1954 års zigenarinventering.

Vol. 9 Forms from Carl-Herman Tillhagen's interviews 1955; Manuscripts for the report Zigenarfrågan. Betänkande avgivet av 1954 års zigenarutredning (SOU 1956).

\section{Literature}

Aronsson, Peter (2004): Historiebruk: Att använda det förflutna, Lund: Studentlitteratur.

Axelsson, Thom (2007): Rätt elev i rätt klass: Skola, begåvning och styrning 1910 1950, Linköping: Linköpings universitet.

Bachtin, Michail (1991): Det dialogiska ordet, Gråbo: Anthropos.

Bergstrand, Carl-Martin (1932): "Om hästslakten och dess utövare," Folkminnen och folktankar, 1932:19, 200-202.

Bergstrand, Carl-Martin (1933-1935): Kulturbilder från 1700-talets Västergötland, Göteborg.

Bergstrand, Carl-Martin (1942): Tattarplågan, Göteborg: Gumperts förlag.

Bergstrand, Carl-Martin (1959): Fångar på Nya Elfsborg under 1700-talet, Göteborg: Gumperts förlag.

Bergstrand, Carl-Martin (1976): Brott och straff i 1700-talets Västergötland, del 2, Självmord, Göteborg.

Blomster, Risto et. al. (2015): "Forskarnas förord," Pany Pulma (ed.): De finska romernas historia från svenska tiden till 2000-talet, Stockholm: Atlantis, 12-17.

Burns, Kathryn (2010): Into the Archive: Writing and Power in Colonial Peru, Durham, N.C.: Duke University Press.

Czarniawska, Barbara (2007): Shadowing and Other Techniques for Doing Fieldwork in Modern Societies, Malmö: Liber.

Derrida, Jacques (1996): Archive Fever: A Freudian Impression, Chicago: University of Chicago Press.

Ericsson, Martin (2012): Svenska kommuners utestängningsstrategier mot "tattare" 1880-1924, Rapport till arbetsmarknadsdepartementet, Lund: Lunds universitet.

Ericsson, Martin (2015): Exkludering, assimilering eller utrotning? "Tattarfrågan" $i$ svensk politik 1880-1955, Lund: Lunds universitet.

Ericsson, Martin (2017): “Såsom det brukas med tattare': Kollektivt våld mot familjer utpekade som tattare eller zigenare 1872-1955," Historisk tidskrift, 137:1, 27-63.

Fernstål, Lotta \& Hyltén-Cavallius, Charlotte (eds) (2018a): Romska liv och platser. Berättelser om att leva och överleva i 1900-talets Sverige, Stockholm: Stockholmia förlag.

Fernstål, Lotta \& Hyltén-Cavallius, Charlotte (eds) (2018b): Undersökning om de så kallade tattare eller zigeuner, cingari, bohemiens. Deras härkomst lefnadsätt, språk m.m. Samt om, när och hwarest några satt sig ner $i$ Swerige? Lund: Nordic Academic Press.

Fernstål, Lotta \& Hyltén-Cavallius, Charlotte (forthcoming A): "Continuity and change in the use of the Swedish labels "zigenare" and "tattare" - an analysis of three eighteenth-century texts from Sweden and Finland," submitted to Romani Studies.

Fernstål, Lotta \& Hyltén-Cavallius, Charlotte (2019): “To stage a minority group — the folklorist Carl-Herman Tillhagen and the photographs in the collection Sweden's gypsies at the Nordic Museum," submitted to ARV-Nordic Yearbook of Folklore. 


\section{Culture Unbound}

Journal of Current Cultural Research

Folkräkningen (1918): Folkräkningen den 31 december 1910, IV. Folkmängdens fördelning efter hushåll, trosbekännelse. Födelseort, m.m., Stockholm: Kungl. statistiska centralbyrån.

Harvilahti, Lauri, Kjus, Audun, O’Carroll, Clíona, Österlund-Pötzsch, Susanne, Skott, Fredrik \& Treija, Rita (eds.) (2018): Visions and traditions: knowledge production and tradition archives. Helsinki: Academia Scientiarum Fennica / Suomalainen tiedeakatemia.

Hammarlund, Anders (2015): Documentum: Ett resonemang om samlande, samlingar och samlare, Stockholm: Svenskt Visarkiv.

Johansen, Jahn Otto (1990): Zigenarnas holocaust, Stockholm: Symposion.

Kirshenblatt-Gimblett, Barbara (1998): Destination Culture: Tourism, Museums, and Heritage, Berkeley: University of California Press.

Klein, Barbro (2000): "Foreigners, Foreignness, and the Swedish Folklife Sphere," Ethnologia Scandinavica, 2000, 5-23

Klein, Barbro (2007): "Folklore Archives, Heritage Politics and Ethical Dilemmas: Notes on Writing and Printing," Bente Gullveig Alver et al. (eds): Research Ethics in Studies of Culture and Social Life, Helsinki: Suomalainen tiedeakatemia, 114 136.

Klein, Barbro (2009): “Telling Stories to a National Archive," Susan Brantly \& Thomas A. DuBois (eds.): The Nordic Storyteller: Essays in Honour of Niels Ingwersen, Newcastle upon Tyne: Cambridge Scholars Publishing, 130-154.

Kotljarchuk, Andrej (2017): "World War II and the Registration of Roma in Sweden: The Role of Experts and Census-Takers," Holocaust and Genocide Studies, 457479.

Lilja, Agneta (1995): Förteckning över Dialekt- och folkminnesarkivets frågelistor, Uppsala: Dialekt- och folkminnesarkivet, Institutet för språk och folkminnen.

Lilja, Agneta (1996): Föreställningen om den ideala uppteckningen: En studie av idé och praktik vid traditionssamlande arkiv: Ett exempel frän Uppsala 1914-1945, Uppsala: Uppsala Universitet and Institutet för språk och folkminnen.

Lilja, Agneta (2003): "Det är dock vi från fältet som håller virket till byrån," Bo G. Nilsson et al. (eds): Frågelist och berättarglädje: Om frågelistor som forskningsmetod och folklig genre, Stockholm: Nordiska museets förlag, 33-43.

Lilja, Agneta (2004): "I förhandling med historien: Arkivsamlingarna vid SOFI, Nordiska museet och Statens musiksamlingar," Oknytt, 3-4, 22-35.

Lundgren, Gunilla \& Dimiter Taikon, Aljosha Nils-Erik (1998): Aljosha: Zigenarhövdingens pojke. Stockholm: Bonnier Carlsen.

Marcus, George E. (1995): "Ethnography in/of the World System: The Emergence of Multi-Sited Ethnography," Annual Review of Antropology, 24, 95-117.

Meddelanden från Etnologiska undersökningen (1943): no. 39, Stockholm: Nordiska Museet.

Montesino, Norma (2001): “The 'Gypsy Question' and the Gypsy Expert in Sweden,' Romani Studies 5, 11:1, 1-24.

Montesino, Norma (2002): Zigenarfrågan: Intervention och romantik, Lund: Socialhögskolan, Lunds universitet.

Montesino, Norma (2010): "Romer i svensk myndighetspolitik - ett historiskt perspektiv," Meddelanden från Socialhögskolan, 2010:2, Lund: Socialhögskolan, Lunds universitet.

Montesino, Norma \& Ohlsson al Fakir (2015): "Romer i Sverige - ett socialhistoriskt perspektiv," Socialmedicinsk tidskrift, 2015:3, 305-314.

Nilsson, Bo G. (1996): Folkhemmets arbetarminnen: En undersökning av de historiska och diskursiva villkoren för svenska arbetares levnadsskildringar, Stockholm: Nordiska museets förlag.

Nilsson, Bo G (2003): "Frågor, svar-och vad mer?" Bo G. Nilsson et al. (eds): Frågelist och berättarglädje: Om frågelistor som forskningsmetod och folklig genre, Stockholm: Nordiska museets förlag, 105-115. 


\section{Culture Unbound}

Journal of Current Cultural Research

Nylund Skog, Susanne (2017): "Brev och belägg i jakten på folkminnen: Den vetenskaplige samlaren," Kulturella perspektiv, 26:1, 36-46.

Ohlsson al Fakir, Ida (2013): Svenska kyrkans förhållande till romer och resande ca 1900-1950, Uppsala: Svenska kyrkan.

Ohlsson al Fakir, Ida (2015): Nya rum för socialt medborgarskap: Om vetenskap och politik $i$ "Zigenarundersökningen"-en socialmedicinsk studie av svenska romer 1962-1965, Växjö: Linnéuniversitetet.

Pira, Sigurd (1942): “Tattarna i Sverige," Landsfiskalernas tidskrift, 4, 45-49.

Pulma, Panu (ed.) (2015): De finska romernas historia från svenska tiden till 2000-talet, Helsingfors: Svenska litteratursällskapet i Finland.

Resløkken, Åmund Norum (2018): "Ein lut av det noere levande livet”: Tradisjon, tradisjonselementer og tradisjonsforskere: En studie av spørrelisteserien Ord og sed 1934-1947, Oslo: Det humanistiske fakultet, Universitetet i Oslo.

Richette, Christian (2003): "Frågelistan. Ett kontextkritiskt perspektiv", Bo G. Nilsson et al. (eds): Frågelist och berättarglädje: Om frågelistor som forskningsmetod och folklig genre. Stockholm: Nordiska museets förlag, 117-129.

Selling, Jan (2014): Svensk antiziganism: Fördomens kontinuitet och förändringens förutsättningar, Ormaryd: Östkultur.

SFS 1914:196: Lag angående förbud för vissa utlänningar att här i riket vistas, Svensk författningssamling.

SFS 2009:724: Lag om nationella minoriteter och minoritetsspråk, Svensk författningssamling.

Sjögren, David (2010): Den säkra zonen. motiv, åtgärdsförslag och verksamhet $i$ den särskiljande utbildningspolitiken för inhemska minoriteter 1913-1962, Umeå: Umeå universitet.

Skott, Fredrik (2000): "Bergstrand, Sandklef and the Frillesås Mark," Arv, 2000:56, 119-138.

Skott, Fredrik (2001): "Most of Your Questionnaires are Terrible to Work With," U1rika Wolf-Knuts (ed.): Output \& Input: The Process of Fieldwork, Archiving and Research in Folklore, Turku: NNF Publications, 75-114.

Skott, Fredrik (2008): Folkets minnen: Traditionsinsamling i idé och praktik 19191964, Göteborg: Institutet för språk och folkminnen and Göteborgs universitet.

Skott, Fredrik (2016): "Kampen om folktraditionen," Saga och sed: Kungl. Gustav Adolfs akademiens årsbok, Annales Academiae Regiae Gustavi Adolphi, Uppsala: Gustav Adolfs akademien.

Skott, Fredrik (work in progress): Kampen om folktraditionen: Förändringen av den folkloristiska forskningsmiljön 1919-1979. (Preliminary title.)

SOU (1923): Förslag till lag om lösdrivares behandling m. fl. författningar. Avgivna av utsedda kommitterade. Del V av Fattigvårdslagstiftningskommittens betänkanden, Stockholm: Socialdepartementet, Statens offentliga utredningar 1923:2.

SOU (1956): Zigenarfrågan: Betänkande avgivet av 1954 års zigenarutredning, Stockholm: Socialdepartementet, Statens offentliga utredningar 1956:43.

SOU (2010): Romers rätt - en strategi för romer $i$ Sverige, Stockholm: Kulturdepartementet, Statens offentliga utredningar 2010:55.

Staten och zigenarna (1960): Arbetsmarknadsinformation utgiven 1960 av Arbetsmarknadsstyrelsen, Stockholm: Kungliga arbetsmarknadsstyrelsen, Arbetsvårdsbyrån.

Stockholms stads tänkeböcker 1504-1514 (1931): Stockholm: Kungl. Samfundet för utgivande av handskrifter rörande Skandinaviens historia.

Svensson, Birgitta (1993): Bortom all ära och redlighet: Tattarnas spel med rättvisan, Stockholm :Nordiska museet.

Takman, John (1966): Zigenarundersökningen 1962-1965. Slutrapport den 31 mars 1966, Stockholm, Uppsala: Arbetsmarknadsstyrelsen, Uppsala universitet.

Takman, John (1976): The Gypsies in Sweden: A Socio-Medical Study, Stockholm: Liber förlag. 
“Tattarnas antal och levnadsförhållanden” (1945): Sociala Meddelanden, 1945:4, 377-392.

Tervonen, Miika (2010): "Gypsies", "Travellers" and "Peasants": A Study on Ethnic Boundary Drawing in Finland and Sweden, c.1860-1925, Florence: European University Institute.

Tillhagen, Carl-Herman (1946): Taikon berättar: Zigenarsagor, Stockholm: Norstedts.

Tillhagen, Carl-Herman (1947): “A Swedish Gypsy Investigation," Journal of the Gypsy Lore Society, third series, XXVI:3-4, 89-115.

Tillhagen, Carl-Herman (1949a): "Gypsy Clans in Sweden," Journal of the Gypsy Lore Society, third series, XXVIII:1-2, 1-16.

Tillhagen, Carl-Herman (1949b): "Gypsy Clans in Sweden," Journal of the Gypsy Lore Society, third series, XXVIII:3-4, 119-133.

Tillhagen, Carl-Herman (1950): “Gypsy Clans in Sweden," Journal of the Gypsy Lore Society, third series, XXIX:1-2, 23-38.

Tillhagen, Carl-Herman (1956): "Zigenarnas levnadsförhållanden 1955: En intervjuundersökning av C.H. Tillhagen," Zigenarfrågan: Betänkande avgivet av 1954 års zigenarutredning, 83-141, Stockholm: Socialdepartementet, Statens offentliga utredningar 1956:43.

Tillhagen, Carl-Herman (1958): Folklig läkekonst, Stockholm: Nordiska museet.

Tillhagen, Carl-Herman (1965): Zigenarna i Sverige, Stockholm: Natur och kultur.

Tillhagen, Carl-Herman (1994): "Högtidsstunder med en stor berättare," Ebbe Schön (ed.): I glädje och sorg: Fataburen 1995, Stockholm: Nordiska museet, 251-276.

Tydén, Mattias (2000): Från politik till praktik: De svenska steriliseringslagarna 1935-1975. Rapport till 1997 års steriliseringsutredning, Stockholm: Statens offentliga utredningar 2000:22.

Vitboken (2014): Den mörka och okända historien: Vitbok om övergrepp och kränkningar av romer under 1900-talet, Stockholm: Arbetsdepartementet.

Westin, Niklas, et al. (2014): Antiziganism i statlig tjänst: Socialstyrelsens behandling av romer och resande under 1900-talet, Stockholm: Socialstyrelsen.

Wiklander, Ludwig (2015): "Resandefolket och svensk minoritetspolitik: 1990-talets paradigmskifte," Historisk tidskrift, 2015:4, 622-649.

“Zigenarnas antal och levnadsförhållanden" (1944): Sociala meddelanden, 1944:2, 116-127. 


\title{
The Small Details in the Archives and the Meaning of a Non-existent Photography from the Home of a Stationer in Helsingborg
}

\author{
By \\ Karin Gustavsson
}

\begin{abstract}
This article describes and problematizes the skills that are used when researching analogue archives. The article deals with the process that operates when a researcher finds small details in archival records that makes it possible to generate a story. Whether it is skill or luck that enables one to find the phenomena that create meaning is also discussed. The empirical example is fetched from the "Swedish Town project" that was initiated with the aim to write a new kind of urban history in the 1940s by Swedish art historian Gregor Paulsson. The researcher Börje Hanssen conducted field work in the city of Helsingborg in southern Sweden during the summers in 1942, 1943 and 1944. The "Swedish Town"-project explored urban history through both traditional sources such as archives, but also by interviews with contemporary town inhabitants and photographs. In the article we meet both Hanssen and some of his interviewees, and his working methods, his texts and some photographs are being analyzed. Börje Hanssen later became an influential ethnologist and in this article we encounter him in the beginning of his career. In order to examine the role played by one small detail in a large amount of material, and how such a detail can influence the researcher's interpretations, Roland Barthes concepts of punctum and studium are used in the article, in order to create meaning out of small, everyday and often seemingly insignificant phenomena. Punctum and studium are fruitful analytical tools, not only in analyzing photographs, which was Barthes original use of the concept but also in other contexts, in this case archival records. The article thus discusses when a detail becomes the punctum that changes the researcher's mindset and enables new knowledge to be produced.
\end{abstract}

Keywords: Field work, Knowledge production, Archives, Photography, Punctum and Studium, Urban history.

Gustavsson, Karin: "The Small Details in the Archives and the Meaning of a Non-existent Photography from the Home of a Stationer in Helsingborg", Culture Unbound, Volume 12, issue 1, 2020: 173-195. Published by Linköping University Electronic Press: http://www.cultureunbound.ep.liu.se 


\section{Introduction}

In July 1944 the Malmqvist family, who lived in Helsingborg, a town located on the coast of southern Sweden, received a visit from a young man who asked them questions about their life at home and at work, their leisure interests and activities, their eating habits, and much more. He made thorough notes, drew sketches of the furniture arrangements in the various rooms, and also took a couple of photographs. The family consisted of a husband and wife in their mid-30s and two school-age boys. The reason for the man's visit to the home in the district of Tågaborg north of the city centre was that, a day earlier, he had entered the stationery store on one of the main streets in the centre of town where the husband and wife both worked. There, he had introduced himself as Börje Hanssen, a student from Stockholm University who, at the time, was involved in a large project entitled Svensk miljö ("Swedish environment"), a study of the changes that had occurred in Swedish homes and towns during the last 100 years. The project was supervised by Professor Gregor Paulsson (1889-1977) from the Department of Art History at Uppsala University. Hanssen was part of a group of researchers that conducted field studies in a number of Swedish towns and urban areas for several years during the 1940s. Their work was intended to result in a commemorative book that was to be finished and released in time for the celebration of the 100-year anniversary of the association Svensk Form, then known as Svenska Slöjdföreningen (The Swedish Society of Crafts and Design) in the autumn of 1945 (Dahlgren 2016: 78).

Traces of Hanssen's visit to the Malmqvist family can now be found in archival records. The aim of this article is to describe and problematize the skills that are used when researching analogue archives. One of the ethnological competences is to create meaning and relationships based on small, everyday and often seemingly insignificant phenomena (see, for example, Löfgren 1997: 96, 110 and Svensson 2012: 16f). In this article, I will describe the process when I look for the details in archived material that make it possible to generate a story, and I will discuss whether it is skill or luck that enables me to find the phenomena that create meaning. I will focus on photographs taken on two different occasions during Hanssen's work: on the one hand the photos he took in the home of the Malmqvist family, and on the other hand a photo that is part of a suite of pictures of Helsingborg's populated environments, but which seems to lack any connection to the other photographs in that series.

Paulsson's intention to produce a commemorative book had to be reconsidered due to many delays and changed circumstances during the years of fieldwork. A written work was instead finally published under the title Svensk stad ("Swedish town"), released in three volumes between 1950 and 1953. Svensk stad has later been regarded as a classical study of urbanisation and industrialisation in Sweden. 
Börje Hanssen (1917-1979) conducted fieldwork in several of the towns on which that publication was based; he came to influence the project greatly and he was also responsible for a large part of the texts that appear in those books. $\mathrm{He}$ eventually became one of Sweden's most influential ethnologists and also enjoyed an international career (Stoklund 1980). A large part of the results of the work that Hanssen performed, such as the Malmqvists' descriptions of what it was like to run a business on Kullagatan in Helsingborg at that time and the family's depictions of everyday life at home, were not included in the published volumes. However, the material that Hanssen (among others) collected on such occasions, as described above-interviews, sketches and photographs-is now stored in the archives of the Nordic Museum in Stockholm.

Before we return to the Malmqvist family, Börje Hanssen and Helsingborg in 1944, and before I address the archived material that I have examined, I will first describe my theoretical starting points and provide some general reflections on ethnology and archives. I will then provide a description of the empirical material on which this article is based and make a short overview of the context in which the fieldworks described in the text were conducted, before moving on to join Börje Hanssen during his visit to the Malmqvist family's home and stationery store. The reader of this article will thus meet both the field-working Börje Hanssen, the practical circumstances surrounding his work in the 1940s, and the researcher of the 2010s trying to follow the tracks of Hanssen through the archived material he created. I will conclude the article with a discussion on the categorisation of material and the importance of the small details when examining a comprehensive amount of archived material.

\section{Theoretical Starting Points}

Ethnologists often create their own material, and they work almost exclusively with qualitative studies (Löfgren 1996: 79f). Being faced with a large amount of already collected material can feel somewhat daunting, and it may also seem of little interest to examine something that other researchers have collected. At the same time, an existing collection of material provides good research opportunities whereby new knowledge can be produced and methodological aspects can be examined and further developed (c.f. Gustavsson 2017). For example, the empirical content of lists of questions and interviews can provide sources of relevant information in connection with new studies involving new issues. Furthermore, the research-related situation that existed at the time the material was collected can be examined and problematized, and contributions can thus be made to studies into conditions and contexts for the production of knowledge. The material I have worked with, including interviews with the Malmqvist family 
and observations from their home, is extremely large. So, what is it that captures my attention, and why? Which details become the bearers of meaning?

In order to examine the role played by one small detail in a large amount of material, and how such a detail can influence the researcher's interpretations, the concepts of punctum and studium can be used. The French linguist and semiotician Roland Barthes has described the element in a photographic image that captures an observer's attention by using the concept of punctum. Studium is everything in the image which, to use Barthes' words, is "perceive[d] quite familiarly" to the observer based on their existing knowledge (Barthes 1981: 25). Studium denotes the expected; not that which surprises the observer, but rather that which confirms what he or she already knows. Punctum, on the other hand, describes that which is temporary and stands out; that which captures the observer's attention (Barthes 1981: 26). Barthes uses the expression "structural rules" when he examines photographs taken in one and the same context by a specific photographer, and he puts into words that which characterises the photographer's imagery. When examining photographs, Barthes sees recurring contradictions in the subject matter depicted in the pictures; elements in the images that are in contrast to each other and create a sort of dualism (Barthes 1981: 23). However, the structure and the rules are extremely subjective; it is Barthes himself, as the observer, who creates them and turns them into tools when he proceeds with his analysis, to which the concepts of studium and punctum are central.

Barthes' concepts have been used to analyse phenomena other than just photographic images. The ethnologist Lotten Gustafsson Reinius examined a museum collection at the Museum of Ethnography in Stockholm with the help of punctum and studium as analytical concepts, and the archaeologist Nanouschka Myrberg used the concepts to interpret archaeological coin findings (Gustafsson Reinius 2009, Myrberg 2012). For Myrberg, this entailed a way of more closely addressing the issue of when and why change has occurred in people's behaviour in the past (Myrberg 2012: 76f). Gustafsson Reinius developed Barthes' concepts by talking about material punctum, whereby tactile and material properties of museum pieces formed part of her understanding of the collection as a phenomenon, and something that could contribute to a clarification of the potential for the production of knowledge that exists in a museum collection (Gustafsson Reinius 2009: 80f).

In this article, the intention is to test these concepts on archived material, with the aim of discovering how a single small detail can become a bearer of meaning and thus contribute to the creation of logic and new knowledge. Even though a photographic image is in one respect unchanging-the subject matter depicted in the image remains the same through the years-its meaning changes depending 
on the identity of the observer. In the same way, a text document can also be said to be unchanging, yet it offers opportunities for the discovery of new meaning through new interpretations. The observer's prior knowledge, expectations and values govern what can be seen in an image, or what he or she is able to read from a written text (Myrberg 2012: 76). A demarcated archive collection, such as Börje Hanssen's personal archive, which is stored at the Nordic Museum, can be said to be unchanging in the same way as an individual photograph. The specific collection remains intact once it has been placed under the care of the archive institution, even though other collections subsequently arrive and add to the institution's collective material. Just like with a single photograph or a single text document, it is constantly possible to reinterpret such a demarcated collection. Its meaning shifts depending on the identity of the observer or the user, and it could be a single small detail that governs the observer's interpretation. Something that represents a meaningful detail for one person, in other words something that contributes to the creation of meaning and context for that person, could be completely overlooked by another person whose work is based on other starting points.

Naturally, the number of objects, and thus the amount of possible interpretations, is much greater in an archive collection than in relation to a single object. Gustafsson Reinius writes about how she experienced "an overwhelming multitude of miscellaneous things" when she entered a museum storeroom and saw the large collections of objects (Gustafsson Reinius 2009: 76). The same feeling can be experienced in relation to the study of archived material. There are many similarities between a collection of documents at an archive institution and a collection of objects at a museum-in both cases, the material is curated with the aim of preserving it for the future, and both categories of material represent people and events from the past and can form a starting point for research in a number of different disciplines. And yet, there are striking differences. The museum collection is the result of a selection process by a professional or group of professionals with the authority and power to decide what should be included in the collective memory that is represented by a collection of objects. Archive collections have often originated outside the influence and reach of the archivist's profession, and they may have been created in a long series of varying contexts. The material that forms the starting point for this article was primarily created as documentation for analyses that were to be presented as text, the production of which was to be closely connected to the actual collection of the material. The ambition of Börje Hanssen and the other members of Gregor Paulsson's work group was not to create a collection of research material that could be used by others in the future, which is precisely one of the intentions of the professionals who create, manage and expand museum collections. 
By studying what a collection consists of and how it is organised, it is possible to draw conclusions about the preferences and ideals of the person(s) who once created the collection (Gustafsson Reinius 2009: 87). The collection itself carries a story about the norms and ideals of those who created it, as well as the practical reality in which they worked. Archives entail possibilities to see the collectors behind the collections, and to bring together and analyse fragments of people from the past to create cohesive descriptions as part of the production of knowledge. It is this aspect that will reunite us with the Malmqvist family and Börje Hanssen a little later in this article.

\section{The Ethnology in the Archives}

Archived material can be compared to parts of a kaleidoscope. The documents that are stored in it can be put together to form an endless array of descriptions and stories. A large number of interesting fragments that are found in different parts of the archives can be put together to form a variety of entities. But while the images created by a kaleidoscope are entirely random, the stories about the past that a researcher constructs from archived material are dependent on the researcher's knowledge goals, skills and research method. While archived material contains a huge amount of possible descriptions and stories, the archives are also problematic due to the risk that the large amount of material might lead the researcher astray. Ethnologist Simon Ekström made the following comment about a research situation where access to available material seemed to be endless: "the difficulty for the inquisitive mind lies not in the finding but in the selection" (Ekström 2017: 9). Both the finding of material and the subsequent selection of relevant material are also processes that depend on factors which are often beyond the researcher's control and influence. In the context I am describing, this has to do, among other things, with how the material has been listed and categorised, with a failure to follow principles that should have been given during such a process. As this article will show, a certain degree of cunning, and the ability to question the headings provided, is sometimes a necessity. Another factor is the distance that exists between the archive researcher and the archive institution, as exemplified by the procedure through which the archived material is ordered by the researcher. As a researcher, I am seldom able to see the collection I intend to work with in its entirety.

I conducted an examination of the large amount of archived material generated by the Svensk miljö project, and various details in the material influenced the direction I took in my work. But how did the selection process actually occur? Was it pure coincidence that I suddenly happened to find certain details that became bearers of meaning, or was it down to my own personal skill and experience when 
it comes to navigating a large amount of material and making the selection, the part of the process Ekström described as the most difficult? Is it possible to identify a punctum in archived material in accordance with Barthes' meaning, and can his concepts be used as tools in the methodology I am applying? Can a punctum exist in text documents as a detail in how the language is used, or in the content, or in the depiction of an unexpected subject in a series of images? Or perhaps in something of material character, like a train ticket or a dried flower or a piece of fabric inside a letter, something the creator of the archive has left behind, together with other types of envelopes, boxes, strings and other materials and devices used to seal and store the collection, which have originated from the person charged with the responsibility of arranging its contents.

The ethnologist Rebecka Lennartsson used the term "archival ethnography" to describe her work with archived documents from the 1700s, whereby she acquired knowledge piece by piece about the material-and about the people whose fates were described there in fragmented form (Lennartsson 2014: 9ff). It is a term and a notion that can also be applied to the work I have undertaken in the archives and, just like Lennartsson, I also have an ambition to describe my own method (aa: 18). In a study where the ambition is to construct a story and produce new knowledge, not just to reproduce facts, the re-use of already examined sources is necessary and represents a way to master the material step by step, and to see and utilise its potential (Gustavsson 2017).

In the Nordic Museum's archives, there are two different collections from the Svensk miliö project; Börje Hanssen's personal archive, and Gregor Paulsson's collection. The latter was stored at the Department of Art History at Uppsala University until 1979, at which time it was transferred to the Nordic Museum's archives (Grünberger 1981: 144). The material contains several hundred interviews conducted with various people in Helsingborg during the 1940s, photographs of buildings, sketches of facade designs and various compilations that the fieldworkers of the time put together after having studied literature and conducted searches in various municipal archives. I saw good possibilities to further enhance and enrich existing knowledge about the town's history of settlement based on the contents of both archive collections (Gustavsson 2019). The material appeared to have been left unused for decades, although it has been partially used by other researchers, primarily the art historian Anders Dahlgren (see Dahlgren 2016 and Dahlgren 2018). 


\section{The Malmqvist Family at Home and at Work}

Gregor Paulsson's ambition of knowledge production based on fieldwork with a focus on interviewing non-academics about their everyday life and photographing people's homes was part of a greater context. European ethnologists, art historians and architectural historians had been using fieldwork methods for decades. In order to map vanishing vernacular architecture and life style, large-scale fieldwork was organised in the rural areas of many countries during the early twentieth century (Stoklund 2003, Gustavsson 2014). During the 1930s, the method was developed by Swedish ethnologist Sigurd Erixon, among others, to also encompass urban traditions and professions (Nilsson 1996). Both Paulsson and Hanssen were strongly inspired by contemporary Anglo-Saxon sociologists such as Lewis Mumford, which can be seen in the correspondence between them, now found in the private archive of Gregor Paulsson. His choice of method to gather empirical data for the Svensk stad project was a result of inspiration from both the well-known tradition of fieldworks in rural environments in Europe and from contemporary sociological works in the United States.

Börje Hanssen was 27 years old, with a background in economic history, political science and human geography. He started his fieldwork in Helsingborg in the summer of 1942, and then returned the the city two years in a row. In 1942 and 1943, Hanssen and a couple of young researchers who were part of Paulsson's group had spent time conducting interviews and performing studies of archives and literature with the aim of mapping how industrialism had influenced both the daily lives of people and the expansion and development of the town. Hanssen had come to feel at home in the town and was well versed in both its past and present thanks to the comprehensive studies of archives and literature that he had undertaken. His activities during the summer of 1943 had included moving around the town with a camera in hand, which resulted in more than 100 photographs with descriptive captions (Gustavsson 2020). During the spring prior to the commencement of his fieldwork, he had begun to explain his views on the role of photography in the study:

As I have already said, the camera should be used to a greater extent. It often requires a certain amount of persuasion before someone will allow you to take photographs in their home, but I think that the results are well worth the effort, especially if it is possible to achieve pictures of the environment from a functional perspective, so to speak; in other words, not just fine pictures of the living room or kitchen on Sundays, but images of those rooms in everyday use during the week, with unwashed dishes and discarded bedclothes and ideally even the people who live there. Such images would definitely bring more life to the work (translation by the author). ${ }^{1}$ 
There is a large number of interviews and descriptions of various homes in Helsingborg, so a relevant question is of course: why have I chosen to focus on the example of the Malmqvist family? For one thing, compared to all the other interviews, the material regarding the Malmqvist family is unusually rich in terms of the scope of its content, and Börje Hanssen's own description suggests that the material should contain both photographs and sketches of the home. This particular example should also be able to highlight Hanssen's work methods well, in addition to a piece of rich empiricism from Helsingborg's past.

The fieldwork during the first two summers had been focused on surveys of people's homes, which was one of the primary elements of Gregor Paulsson's project. Since there was so little literature available about the changes that had taken place in Swedish homes during the last 100 years, it was necessary to ask people about it. Elderly people were asked to describe their childhood homes, and interviews were combined with visits for the purpose of observing the contemporary homes of the time. In July 1944, however, Hanssen had another assignment. On this occasion he visited a long line of shops along Kullagatan, one of the main streets in Helsingborg. His aim was to gain an overview of the range of goods on offer, the types of customers who visited the shops and their turnover, as well as the physical characteristics of the shops in terms of their furniture and fittings and the windows, displays and signs that faced the street. This was to complement the surveys of people's homes, and the purpose was similar. It had to do with collecting empirical material that would be used for descriptions and analyses of the changes that had occurred during the last 100 years. It is in this context that Hanssen visited stationer Malmqvist on Kullagatan 12. However, it soon became apparent that work and home life were closely intertwined for this self-employed businessman. Hanssen therefore also interviewed Malmqvist - and perhaps his wife as well, although that particular detail is not apparent from the material - about their home. Hanssen made notes, and he drew sketches of how the rooms were furnished, including the location of lamps. It is apparent from his documentation that he also took photographs in the couple's home.

On the first page of his account of the stationer's home, Börje Hanssen has written that it consists of 19 pages in total, plus sketches of the layout of the home and some photographs. Initially the family and their personal details are presented. The Malmqvists had two sons, one of whom attended school. The couple had married in 1935, and they were now both about 35 years old. It is stated that both the husband and the wife worked in the store, which sold books, stationery and souvenirs. Their home was a rented apartment in a detached house in the northern part of town. Hanssen goes on to describe how both the man and his wife had graduated from upper secondary school, and that both had grown 
up in what he refers to as "middle-class homes" (Volume 2 in Gregor Paulsson's collection, Nordic Museum's archives) .

The 18 pages that follow contain a description of the Malmqvists' home and everyday habits. The description covers almost the entire apartment, which consisted of three rooms and a kitchen. The living room, library, bedroom and kitchen have each been given a separate heading in Hanssen's description, but he makes no comment about the hallway, bathroom or any other areas. The family had a maid, who lived in a room in the attic of the house, but her living quarters also pass without comment in the description. Even though the questions Hanssen must have asked are not specifically listed, the account he provides makes it possible to make an educated guess. His questions related to matters such as the various pieces of furniture in the home-had they been inherited, where and when were they purchased, and how and when were they used? What was the function of the various rooms? Which mealtimes were taken at home, and which were taken at work? At the top of each page, there are a couple of keywords that summarise the contents of that particular page. The same method was employed for all the interviews from Helsingborg, with one or two keywords written at the top of each page to capture the essence of the contents of that page. The use of headings was one way of categorising the content and creating clarity, with the aim of facilitating the comparison of different interviews with each other.

Börje Hanssen's text in the description of the Malmqvists' home is based on both his own observations and what the husband and wife said, although it is very clear that Hanssen's own voice is the dominant one in the narrative. $\mathrm{He}$ often appears not only to be observing the home but also to evaluate what he sees and to record his evaluations. The Malmqvists have referred to one of the rooms as the library. In his account, Hanssen has written the word "library" in quotation marks, suggesting that he does not entirely agree with the interviewees as to whether this is, in fact, an appropriate name for the room in question. The quotation marks have clearly not just been used by accident; Hanssen has had a definite intention when using them. In the account from the home, in which the rooms, furniture, decorations and lamps are listed and described, one message in particular is highlighted.

Hanssen notes in his description how the Malmqvists draw particular attention to "the inherited pieces", and how their age and foreign origin are of importance to the couple. A clock is said to have been purchased in Paris in 1905 by the parents of one of the spouses. Hanssen also notes that the bookshelves with their books "serve the social prestige". Items of furniture, lamps and other fittings have been assigned a number that indicates their placement on a sketch of the layout of the apartment. The answers to the interview questions have been reformulated by Hanssen, although sometimes a direct quote from one of the spouses has been written in quotation marks, as extra clarification that it is, in fact, a direct quote. 
Sofa 22 must be deemed to be for display purposes and is primarily used when guests are invited. The 'library' is the closest equivalent to a drawing room in terms of its function.

When they have just a single guest, it is possible to take afternoon tea on sofa 22. 'It is low in relation to the table'.

The lamp behind it is primarily for display purposes.

When they have several guests, they eat in the living room as usual.

If they play cards, this is done in the library.

If they have offered their guests coffee only, they remain seated at the table and talk, but if a hot meal has been served and the dishes must be cleared away, they retire to the library after the meal. (translation by the author $)^{2}$

In the extract above, Hanssen refers to a sofa that is for "display purposes", and the same reference is made in relation to a lamp. In all likelihood he means that the function of the sofa is connected to when the couple is receiving guests, a situation in which the home is displayed to people other than members of the family, and is also used together with the guests. The 19 pages are mostly filled with descriptions of this nature about how the furniture is arranged and used, along with descriptions of lamps and how they are used. But there is also a considerable amount of information about the family's eating habits and everyday life. The wife takes care of the bookkeeping at home in the evening. Breakfast is taken at 08:30 in the morning and consists of porridge and milk along with some warmed-up leftovers. The husband and wife then take sandwiches to the shop, with cheese being the most common filling. During the winter, the couple both work in the shop until late in the evening, and on such occasions the maid takes care of the two boys and makes sure they get to bed on time.

Gregor Paulsson demanded that his team members kept a diary in which they were to write down all the work they had performed. The diaries were sent to Paulsson on a regular basis. In one such diary, it is recorded that Börje Hanssen conducted the interview with Malmqvist on 24 July. On that same day, he had also interviewed one other resident of Helsingborg and had visited a construction engineer who was responsible for a residential area under construction, which 
would also be included in Hanssen's study. He had also worked with maps that day. The following day he had taken photographs at the Malmqvists' home and had also carried out a number of other tasks for his assignment on behalf of Paulsson (Volume 14 in Gregor Paulsson's collection, Nordic Museum's archives). Hanssen's diary reveals that Malmqvist was just one of a great many informants. When I read the entries in the diary, I get the impression that the visit to the Malmqvist's home and shop cannot have taken too many hours to complete, even though the account of the visit is one of the most thorough and most comprehensive of all the studies undertaken in Helsingborg during the Svensk miljö project. According to Hanssen's notes, there should also be sketches of the furniture arrangements as well as photographs from the Malmqvist's home. However, these have not been stored together with the description.

\section{The Unreliable Archives}

So where were the photographs and sketches from Malmqvist's home that Hanssen's notes indicated should also have been included? They had not been placed in the same archive box as the text material, but it is not uncommon for photographs to be separated from other documents and stored on their own due to their nature and the way they must be preserved. From the archivist's perspective this is the correct manner in which to proceed, but for the user of the archives it means that material that has been created in the same context ends up in physically separate storage solutions. They were not included among the photographs on the archive list of pictures of various subject matters from Helsingborg. The fact that these sketches and photographs were missing represented an irritating gap in the material, which I felt made my interpretation of Hanssen's work more difficult and meant that I could not gain a sufficient understanding of what things really looked like in the home of the Malmqvist family in 1944.

The material gathered by Hanssen in Helsingborg was used by both Hanssen and Paulsson after the fieldwork was finished, and it had been circulating between them both and Paulsson's department in Uppsala. It was not Hanssen himself who was responsible for the making of archival records. Several of Paulsson's assistants, and later on archivists, handled the material after the project was eventually finished. So, there were many occasions for mistakes to be made.

A gap such as the one described above can have many reasons. It may be due to what the German media theorist Wolfgang Ernst calls "passive absence", in other words that something never actually existed, and other times it has been actively removed as an exercise of power (Ernst 2015: 14). In this case, however, both scenarios seemed unlikely-Hanssen himself has written that there should 
be photographs in the material, and it is difficult to find any logical reason why they would have been intentionally removed. It is therefore likely that there may have been other reasons for this particular gap in the material. It is of course possible that the photographs never existed. Perhaps Börje Hanssen simply got a bit confused about where he had been with his camera and where he had taken pictures. Alternatively, the pictures he took may not have turned out to his liking, and he may therefore never have included them in the final material. Another possibility is that they disappeared before the Svensk stad volumes were published in the early 1950s. The sketches of the furniture arrangements could have remained nothing but basic sketches that subsequently disappeared in the process when everything was to be redrawn and refined. There are many different scenarios that could explain why the images that were intended as a complement to the written material were not in the archives.

This gap, the fact that the photos and drawings of Malmqvist's home were missing, acted as a sort of punctum in my examination of the material. Barthes writes about how he perceived the lack of a connection between two different elements in a photograph, and how this made him stop and think as he observed the image (Barthes 1981:23). For me, the absence of material that should have been in the archives was a similar experience. The fact that this material was missing became a source of focus and irritation on my part, even though there were over 100 interviews from Helsingborg and it was never going to be a problem for me to achieve my knowledge goals, which were focused on the history of the town's settlement and development and the more general conditions experienced by its residents (Gustavsson 2019). There were many other interviews, photographs and sketches that I could have studied more in-depth, and the existing material from the Malmqvist family that I had in front of me was of the utmost interest as documentation for analysis and interpretation, but there was something about the material that was missing that I just could not let go of. This irritating gap in the material made it difficult for me to discard the notion that, despite everything, these photographs and sketches might actually be there somewhere, in one of the two archive collections. The punctum that this gap in the material represented encouraged me to conduct further investigations into the matter.

Archive collections are arranged and equipped with lists that aim to create order and make it easier to find a specific item among all the available material. At the same time, the manner in which a collection is classified also governs the knowledge that can be gained from it (Ernst 2015: 13ff, 88). Furthermore, despite the best intentions, archive collections always contain some degree of disorder (Myrberg 2012: 75). The order that has been created can exist on different levels, 
from having only one single heading for an entire (unlisted) collection, to a carefully listed collection with a high degree of detail. The latter case knows no finite bounds-it is always possible to make notes about a collection of documents at an even greater level of detail.

In an archive collection with only a very general, overall list of its contents, the percentage of incorrectly listed documents is lower than for a collection that has been carefully listed in detail. The higher the level of ambition regarding the degree of detail, the greater the likelihood that an error will be made. In the collections that stem from the Svensk miljo project, both of which are stored in the Nordic Museum's archives, there are lists indicating the existence of photographs from Helsingborg in several different volumes.

Volume 3 in Gregor Paulsson's collection contained a couple of pictures, the subject matter of which I found difficult to localise. I could not recognise them as being from Helsingborg (and having worked in the town for many years, I am extremely familiar with its central areas). Consequently, it seemed logical that these pictures must be from one of the other towns included in the project. Sure enough, after a few relevant comparisons, the answer quickly became apparent; these were a couple of pictures from the town of Örebro in central Sweden, which had mistakenly ended up under the heading Helsingborg. If the person who wrote the heading on this volume had been satisfied to simply write "photographs", the heading would have been correct; but the higher level of ambition to provide a greater degree of detail by also stating the name of the town gave rise to an error. Naturally we are dealing with an obvious paradox in such a situation - a lower degree of detail in the list of an archive collection creates more work for the researcher, since it is necessary to go through more volumes in order to find what you are looking for. It may be more difficult to find the object of the search, but on the other hand the likelihood of errors in the categorisation is lower.

Armed with the knowledge that a couple of Örebro pictures had incorrectly ended up in a Helsingborg volume, I was taken by the impulse to conduct a reverse search and look at some of the volumes that (according to the list) should have contained material from Örebro, even though it was never my intention to include Örebro in my study. The archive personnel fetched a volume with the notation "Åtvidaberg and Örebro". ${ }^{3}$ At the very top of its contents there was an envelope with the notation "Unnamed contact prints". The contents of that envelope included a photo reproduction of an older painting of a farm on the outskirts of Helsingborg. This was followed by photographs from Örebro, just as the volume's label had promised. 


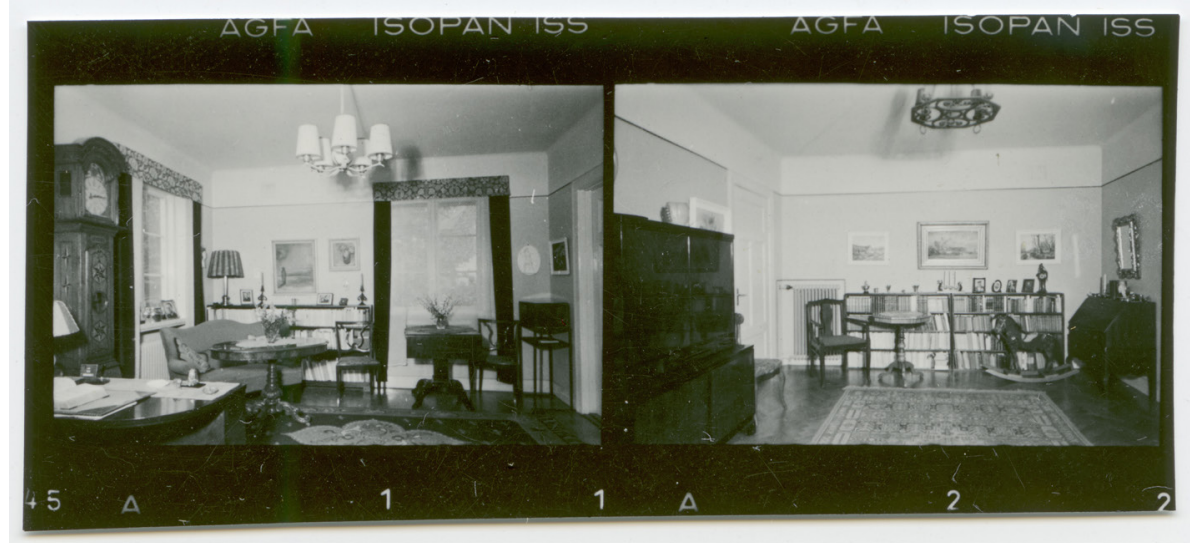

Fig. 1

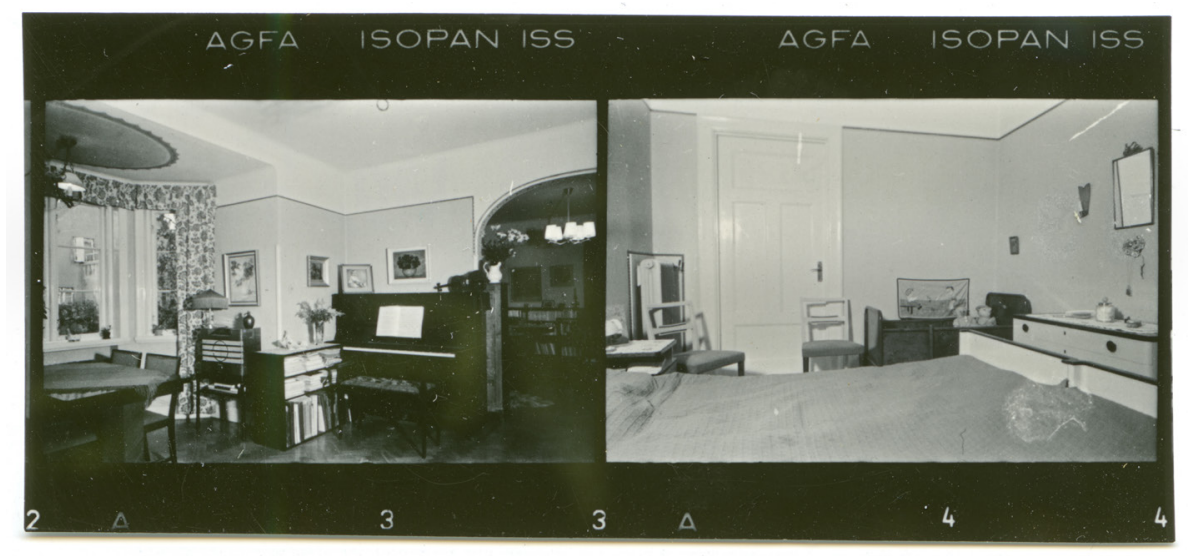

Fig 2. The photograps in Figures $1 \& 2$ originate from volume 18 in the private archive of Börje Hanssen, the Nordic museum.

The envelope also contained four contact prints in 135 film format, 24x36 mm. The images seemed to depict a home environment, and on the back of the prints the name "Malmqvist" had been written in Hanssen's handwriting, which I was now able to recognise. In other words, these were in fact the pictures that Hanssen took of Malmqvist's home, and which were missing from the volume with the Helsingborg material that contained the description of the home.

One error in the archive list had led me to the discovery of yet another error, but on this occasion the error meant that I was able to find the pictures that I had been missing. An error had in fact also been made in the notation on the outside 
of the envelope-these contact prints had indeed been named, just not with a topographic reference. All of the archive material that has been described to date in this article stems from Gregor Paulsson's collection. From the end of the project until 1979, two years after his death, it was stored at his department in Uppsala, where it is likely that the order that had been created in the various archive boxes remained the same as it had been during the time of the project. The art historian Anders Dahlgren has described the "chaotic circumstances" that, to some extent, characterised the Svensk miljö project (Dahlgren 2016: 78). The disorder that exists in the collections, with misleading headings and clearly incorrectly placed objects, can be seen as a reflection of the conditions (disorder) that prevailed during the project itself (compare with Gustafsson Reinius 2009: 86ff).

So, did I really need these photographs for my work? Did they enable me to draw conclusions that I would not otherwise have been able to? Barthes refers to the photograph's relationship to its subject matter as indissoluble; "A specific photograph, in effect, is never distinguished from its referent" (Barthes 1981: 5). And I must concur that this was indeed the case. Despite the thorough written descriptions of Malmqvist's home, it was not until I was also able to place these small photographs in front of me that I could really understand what Hanssen had seen. Now I was seeing exactly what Hanssen had seen through his lens; that which he had chosen to photograph, or perhaps that which he was able to or had been given permission to photograph. The photograph points something out to the observer (Barthes 1981: 5).

The Malmqvist family are not in view in the pictures, but their candelabras, curtains and rugs are, and this makes it possible to recognise the furniture arrangements described in Hanssen's texts. The floors are polished, and everything looks well cleaned and in orderly condition. Trees can be glimpsed through the thin curtains in the windows. My sensation when viewing the pictures is that this was probably a comfortable home; and such a sensation could not have been experienced simply by reading Hanssen's descriptions.

There is also one photograph of the bedroom. This is an indication that the family were prepared to let Hanssen into their more private, intimate sphere. $\mathrm{He}$ has not simply stood in the doorway looking into the room; he has entered and has taken a picture facing the doorway and the area beyond. It looks to have been a very confined space. There is a double bed in the middle of the room. A child's bed is positioned against a wall. In Hanssen's account, he reports a statement by one of the parents that they would eventually have to move to another home, so that their sons could have a room of their own. The photograph only shows one child's bed, but the text confirms that the entire family slept in one and the same room. The text and the photography provide confirmation of each other, and the fact that Hanssen was permitted to enter the bedroom in such a manner tells me 
something about the situation that existed when he visited the Malmqvists' home. In this respect there are many different possible scenarios that can be considered. Was it an indication that the young stranger with his camera had succeeded in winning the trust and confidence of the Malmqvist family, or should the situation be interpreted as some form of submissiveness on the part of the family when visited by an academic researcher working on an important assignment? The photographs from the Malmqvist's home invite their observer to indulge in speculation regarding the situation in which they originated, but the only thing we can truly know for sure is that at least four pictures were taken.

The answer to my initial question regarding the necessity of the photographs is twofold. On the one hand, they gave me a lot. They brought me closer to both Hanssen and the Malmqvist family than I could ever have come if I had only been able to read Hanssen's descriptions. In exploring people's everyday life, images like these are outstanding sources (Burke 2001:81). The presence of these photographs also aroused questions regarding the rooms and living areas that were not visible in them-the kitchen, the hall, the broom cupboard, the bathroom-what did those areas look like, and why did Hanssen take no pictures of them? On the other hand, it would of course have been possible for me to use the written material available as empiricism even without the photographs, but in that case the results of my analyses and interpretations would have been different.

The fact that the sketches of the furniture arrangements were still missing was of no great consequence to me (but perhaps they would have been of more importance to another researcher). I would certainly have been interested in seeing a sketch of the layout of the entire apartment, in order to better understand the position of the rooms in relation to each other, but it is reasonable to assume that Hanssen's sketches contained only the same information that is already available in his written description of the home.

\section{The Peripheral Details}

During my work in the archives I also came across other pictures that seemed to be peripheral to the context in which I was primarily interested, namely the history of the town's settlement and development. Earlier in this article I mentioned a series of pictures that Hanssen took during the summer of 1943, the subject matter of which consists of buildings, streets and places in Helsingborg (Gustavsson 2020). There is one exception however: a picture that depicts the interior of a room with a bed against a wall. 


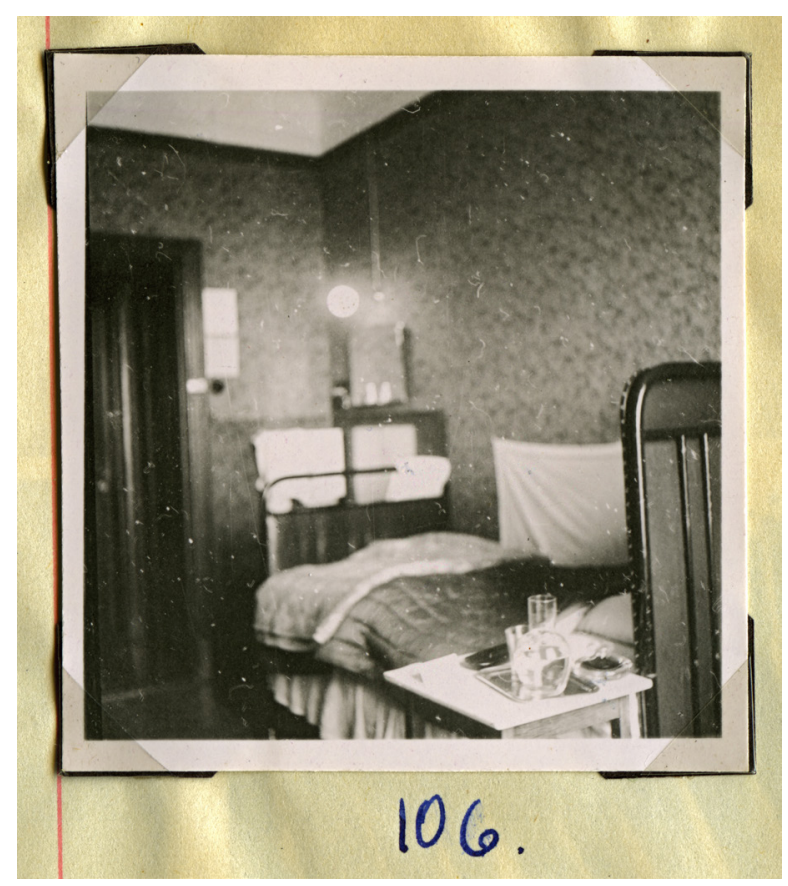

Fig 3. The picture in figure 3 originates from volume 69 in Gregor Paulsson's collection, the Nordic museum.

The bed is made up, but there is no bedspread. A glass of water rests on a table next to the head of the bed, and there appears to be a mirror on the wall, with a glowing, spherically shaped wall lamp above it. The image is fuzzy, and it is not possible to discern all the details it contains. It has been denoted as number 106 in the number series Hanssen applied to his pictures. According to his notes, this picture was taken in a room at the Hässleholm City Hotel on August 5 at 7 in the morning. The town of Hässleholm is a railway hub located about 80 kilometres to the east of Helsingborg, and when this picture was taken, Börje Hanssen had already finished his 1943 fieldwork in Helsingborg and was on his way to another location to continue his endeavours.

Börje Hanssen himself is not visible in a single photograph from the fieldwork conducted in Helsingborg, but this image of the room he stayed in during his journey from Helsingborg provided me with a closer connection with his work. This one photograph, seemingly lacking any connection to the other photographs and the interviews from Helsingborg, gave me a better sense of the conditions of the fieldwork Hanssen performed, something that has not been conveyed in any of his texts. The large amount of documents included in the archive collections that are a result of his work gave me an understanding of his intellectual capacity 
through the questions he had formulated, the great many interviews he had conducted, and the traces of the archive and literary studies he had undertaken. The image of the bed in the hotel room early in the morning made me think of a tired person, on a journey a long way from home to undertake fieldwork that, based on the material I have studied, seems to me to have been extremely demanding, intellectually, socially and physically speaking. My focus was on the fieldwork in Helsingborg during the 1940s. The image of the hotel room had absolutely nothing to do with that. Yet, at the same time, it came to represent a link between then and now, between me-a researcher in the twenty first century studying the conditions for research undertaken in the 1940s-and the individuals who were active in the performance of the research at that time. In my examination of a large amount of material, this one individual photograph came to be a punctum in the archive collection, something that turned my thoughts in a new direction. The photograph constituted a "surprising oddity" that facilitated new thoughts in new directions (Gustafsson Reinius 2009:81).

In relation to the context I was studying-Hanssen's fieldwork in Helsingborg -this was initially a photograph without any empirical content and yet, it came to be filled with meaning. Even though no person is visible in the picture, it was still able to convey the experience of the conditions of the fieldwork at that time. The fact that Hanssen not only dated it but also noted the time of day at which it had been taken also made it possible to place it into a context, and this information, together with the image itself, was like a diary entry from the fieldwork. The photographs from Helsingborg in the summer of 1943 are dated from the middle of July until August 3. The following day, Hanssen commenced his journey from the town and, after spending one night in Hässleholm, he continued on his way to some new destination on August 5. The other photographs, that were initially missing and that I subsequently found, had the character of a sort of trophy, as archive finds sometimes do. In terms of knowledge they contributed to the progress and quality of my work. But this seemingly meaningless photograph, together with the notes about where and when it was taken, was filled with meaning in another way.

\section{What is Needed, and when is it Finished?}

Initially I considered the question of the skills that are needed when navigating a large amount of material. Simon Ekström comments that it is not the actual finding of the material but rather the selection process that represents the true difficulty (Ekström 2017: 9). But when the archive's classifications are inadequate or incorrect, which caused me problems when I was looking for the entire material from the home of stationer Malmqvist, the actual finding of the material is also characterised by difficulty. Practical factors like the available time and 
resources govern the work of searching in archives, but so does the competence that enables the researcher to determine when it is time to stop looking and start the final selection process. Such competence is developed as experience is added to experience, for example when it becomes possible to identify a particular individual's handwriting. Local knowledge about the place from which the material stems also contributes to understanding. In this context it is also necessary to include the ability to create meaning out of something that may initially appear to be meaningless, whereby punctum as an analytical concept is a useful tool.

I have examined a part of Hanssen's work in Helsingborg in the mid-1940s, where both his fieldwork and the result of it-the archival records-have been of importance. Not only the documents themselves but also the archival structure, in other words how the material was organised, are considered as important sources of knowledge. In the selection process, a search for meaning-bearing details has been crucial. The details that stick out may initially appear to be only peripheral in nature, but such details can highlight the conditions that the rest of the material - studium in Barthes' meaning-fails to capture. The presence of punctum is not always detected the moment the researcher reads a text, searches documents in the archive or examines a picture. It is in the nature of punctum that it comes into sight when a research process has been ongoing for a while, after hours, days and perhaps weeks examining sources with the character of studium, when a feeling of information overflow might appear. The absence of something expected can also operate as punctum when such an absence makes it necessary to change focus and detect meaning from what available and unavailable sources can nonetheless say.

As we have seen from the examples discussed in this article, a shortcoming in the cataloguing of material is in itself a bearer of knowledge about how the collection has been managed. Initially, the collection was not placed in order and listed by professional archivists but is instead still arranged and stored on the basis of the logic that prevailed when it was first created during the 1940s and 1950s. Consequently, the collection represents knowledge about the work processes of a time gone by, in a manner that would not have been possible if it had been the subject of thorough professional measures to put it in order and list it accurately based on the new order (c.f. Engström 2015: 254, where an "archive-archaeological" method is described). The lack of consistency in the archive collection that I gradually discovered during my work with the material provided me with experience that eventually led me to find the "right" box. The ability to question the order denoted by the labels on the archive boxes hinted at the necessity to search still further, and it is such an ability to question categorisations, based on experience gained from misleading or incorrect headings, which appears as both a method and a competence in relation to archive research work. 
Karin Gustavsson holds a $\mathrm{PhD}$ in ethnology. She teaches ethnology and museology at the department for arts and cultural sciences at Lund university, and is also the manager of the Folk Life Archive at Lund university. Her research interest is mainly in the field of cultural history. The current article has derived from a research project that explores the archive of the Swedish town project from the 1940s and 1950s. Email: karin.gustavsson@folklivsarkivet.lu.se

\section{Notes}

1 The text in original: Som jag redan tidigare sagt, borde kameran komma till användning i mycket högre utsträckning. Det fordras ofta en viss övertalning för att få fotografera i hemmen, men jag anser att resultaten skulle vara väl värda besväret, speciellt om man sökte få fram miljöbildernas så att säga funktionsutseende: inte paradrummet eller köket på söndagarna utan i vardagslag, med disk och sängkläder och gärna även människor. Sådana bilder skulle ge åtskilligt mera liv åt arbetet. Hanssen to Paulsson 06/04/1943, vol. 501 G:1 in Gregor Paulsson's personal archive, UUB

2 Soffan 22 måste anses vara representativ och användes huvudsakligen då man har gäster. 'Biblioteket' motsvarar närmast finrummet till funktionen.

Då det är någon gäst kan man inta te i soffan 22. 'Den är ju låg i förhållande till bordet'

Lampan bakom väsentligen representativ.

Då det är gäster, äter man som vanligt i vardagsrummet.

Spelar man kort, sker det i biblioteket.

Har man bjudit på kaffe enbart, sitter man kvar vid mellanbordet och pratar, men har man bjudit på varmrätt och skall dukas av, drar man sig ut i biblioteket efteråt.

Volume 2 in Gregor Paulsson's collection, Nordic Museum's archives.

3 Volume 18 in Gregor Paulsson's collection, Nordic Museum's archives. Åtvidaberg is a small town in the southeast of Sweden.

\section{References}

\section{Archives}

Nordiska museets arkiv, / Nordic museum

Börje Hanssens personarkiv / Private archive of Börje Hanssen

Gregor Paulssons samling / Gregor Paulsson's collection

Uppsala universitetsbibliotek / University Library of Uppsala

Gregor Paulssons personarkiv / Private archive of Gregor Paulsson 


\section{Culture Unbound}

Journal of Current Cultural Research

\section{Literature}

Barthes, Roland (1981): Camera Lucida: Reflecions on Photography. New York: Hill and Wang.

Burke, Peter (2001): Eyewitnessing: The Use of Images as Historical Evidence. Lo ndon: Reaktion Books.

Ekström, Simon (2017): Humrarna och evigheten. Kulturhistoriska essäer om konsumtion, begär och död. Göteborg: Makadam.

Dahlgren, Anders (2016): "The Svensk stad (Swedish Town) Project-Architectural History in Action. Konsthistorisk tidskrift/Journal of Art History, 85:1, 76-84.

https://www.tandfonline.com/doi/full/10.1080/00233609.2015.1116023

Dahlgren, Anders (2018): "Fullständigt otillförlitlig, men absolut oumbärlig". En historiografisk undersökning av projektet Svensk stad, doctoral dissertation. Göteborg University.

https://gupea.ub.gu.se/handle/2077/54585

Engstöm, Elin (2015): Eketorps veckningar. Hur arkeologi formar tid, rum och kön, doctoral dissertation. Stockholm University.

Ernst, Wolfgang (2015): Stirrings in the archives: order from disorder. Lanham, MD: Rowman \& Littlefield.

Grünberger, Tulla (1981): “Arkivmaterialet till Svensk stad”. Thomas Hall \& Ingrid Hammarström (eds.) Perspektiv på Svensk stad. Staden som forskningsobjekt 1950 1980. En skrift från projektet Svensk stadsmiljö, byggande och boende under de senaste hundra åren. Stockholm: Akademilitt., 144-155.

Gustafsson Reinius, Lotten (2009): "Sensing through white gloves: On Congolese objects in Swedish Collections". In: The Senses \& Society, Vol. 04, no 01. 75-97.

http://eds.b.ebscohost.com/eds/detail/detail?vid=0\&sid=522cd676-854e-4600-9d35 $-5 \mathrm{c} 0$ cef4ce $2 \mathrm{ca} \% 40$ sessionmgr 120\&bdata $=$ JnNpdGU9ZWRzLWxpdmUmc2NvcGU9c210ZQ $\% 3 \mathrm{~d} \% 3 \mathrm{~d} \# \mathrm{AN}=38698569 \& \mathrm{db}=\mathrm{a} 9 \mathrm{~h}$

Gustavsson, Karin (2014): Returning to the Archive in Search of Everyday Practices in Fieldwork. Ethnologia Europaea, Journal of European Ethnology. Vol 44:2. 61-75.

Gustavsson, Karin (2017): Kunskap ur tomrum. Närläsning som etnologisk metod. Lars-Eric Jönsson, \& Fredrik Nilsson (eds.) Kulturhistoria. En etnologisk metodbok. Lund: Institutionen för kulturvetenskaper, Lunds universitet.

https://lup.lub.lu.se/search/publication/97af2335-280c-47c5-b7ab-eb1dcb4e6d54

Gustavsson, Karin (2019): "Platsen för industrialismens drama. Om Söder i Helsingborg och bokverket Svensk stad". Pål Brunnström \& Ragnhild Claesson (ed). Creating the city: Identity, Memory and Participation. Conference proceeding. Malmö, Malmö University, 161-179.

Gustavsson, Karin (2020): "What Börje Hanssen saw: About photographic imagery and knowledge of a town". Peter Aronsson, Andrej Slávik \& Birgitta Svensson (eds). Images in History / History in Images. Towards an (audio)visual historiography. Kungl. Vitterhets Historie och Antikvitets Akademien Series: Konferenser 99, 59-72.

Götselius, Tomas (2008): “Åter till arkivet”. Foreword. Wolfgang Ernst. Sorlet från arkivet. Ordning ur oordning. Göteborg: Glänta.

Lennartsson, Rebecka (2014): "Arkivetnografi eller reflektioner över en tappad biljett”. Kulturella Perspektiv 2014:3, 8-19.

Löfgren, Orvar (1996): "Ett ämne söker sin väg”. Billy Ehn \& Orvar Löfgren (eds.) Vardagslivets etnologi. Reflektioner kring en kulturvetenskap. Stockholm: Natur och kultur, 13-87.

Löfgren, Orvar (1997). "Scenes from a troubled marriage: Swedish ethnology and material culture studies". Journal of material culture. 1997(2):1, 95-113. 
Myrberg Burström, Nanouschka (2012): "A Study of Punctuality: Using typo-chronology as Barthes' studium and punctum". Nanouschka Myrberg Burström \& Fredrik Fahlander (eds.) Matters of Scale: Processes and courses of events in the past and the present. Stockholms universitets förlag, 75-89.

Nilsson, Bo G. (1996): Folkhemmets arbetarminnen. En undersökning av de historiska och diskursiva villkoren för svenska arbetares levnadsskildringar, doctoral dissertation, Stockholm University.

Stoklund, Bjarne (1980): “Börje Hanssen 1917-1979”. Ethnologia Scandinavica. A Journal for Nordic Ethnology 1980, 155-157.

Stoklund, Bjarne (2003): "Ethnology and vernacular architecture. Revisiting a classical field of study". Ethnologia Scandinavica vol 33, 5-20.

Svensson, Birgitta (2012). Varför etnologi?:En ämnesintroduktion för nya studenter. 1. uppl. Lund: Studentlitteratur. 


\title{
From Oskar Parish, Småland, to Manistique, Michigan: Placing People and Depicting Places ${ }^{1}$
}

\author{
By \\ Susanne Nylund Skog
}

\begin{abstract}
Karl Gösta Gilstring's folklore collection is the largest made by a single Nordic researcher in modern times. The basis for the collection was the network of approximately 700 informants with whom Gilstring corresponded. In this article, the empirical focus is on Gilstring's correspondence during the 1960s with one of the informants, Carl Nelson, living in Manistique, Michigan. In the collection, Carl Nelson represents Oskar Parish, despite the fact that Nelson only lived there until he was seventeen and, in his stories, seldom referred to the parish. What were the ideological and scientific premises for such a connection between a person and a place? How did Carl Nelson depict the places of Gilstring's interest? The aim of the article is to explore how Carl Nelson depicted places in his stories, as well as to contextualize the stories with an analysis of the ideological and scientific premises of Karl Gösta Gilstring's collection. In addition, the article aims to highlight and discuss the working method of such an analysis. The article concludes that the reason why Gilstring changed the spatial references of Nelson's letters, making it seem as if they spoke of Oskar Parish probably had to do with the way his collection was organized. The ideological and scientific premises for the collection required that the customs and traditions of an individual, in order to be understood as such, needed a geographical place of origin. However, the analysis shows that the stories included in Carl Nelson's letters do not primarily convey traditions and customs from Oskar Parish. Instead, they depict a mythological landscape recreated by the emigrant Carl Nelson in his American home on the outskirts of Manistique, Michigan.
\end{abstract}

Keywords: Story/stories, Emigrant, Folktale, Place, Folklore collection, Archive, Method.

Nylund Skog, Susanne: "From Oskar Parish, Småland, to Manistique, Michigan: Placing People and Depicting Places", Culture Unbound, Volume 12, issue 1, 2020: 196-216. Published by Linköping University Electronic Press: http://www.cultureunbound.ep.liu.se 


\section{Introduction}

There is probably no other parish in Småland or anywhere else in our country, where folk life is so thoroughly depicted as Oskar Parish in Southern Möre, through the manuscript that is entirely composed of Carl Nelson's collection of letters. (ULMA 34 838) ${ }^{2}$

This quote is taken from Karl Gösta Gilstring's folklore collection at the Department of Dialectology and Folklore Research in Uppsala. ${ }^{3}$ The collection consists of more than 8,000 original letters, as well as many recordings, from which Gilstring made 70,000 records, divided into 117 parish collections and organized according to content. Karl Gösta Gilstring worked with the collection over a period of fifty years, and it is generally regarded as the largest collection made by a single Nordic researcher in modern times (Lindqvist 1993: 63). The basis for Gilstring's collection was the network of approximately 700 informants with whom he corresponded. The abstract above comes from Gilstrings's notes on one of the informants, Carl Nelson, with whom Gilstring corresponded during the 1960s. In this article, the empirical focus has been placed on their correspondence. There is a widespread assumption that a connection exists between a place and the people who inhabit it and that "where someone is born has a special importance for identity"; so this place of birth, for instance, is recorded on birth certificates and in passports (Taylor 2012: 13). In this manner, who people are is indicated by their place of origin and, in turn, they can claim their place of origin as home, a place to which they naturally belong (Taylor 2012: 51).

From the quotation, it is obvious that one person, by himself, could describe and represent a whole parish in Gilstring's collection. What were the ideological and scientific premises for such a connection between a person and a place? Who could represent the places of interest and how was this done?

\section{Aim, Stories and Places}

The aim of the article is to explore how Carl Nelson depicted places in his stories, as well as to contextualize the stories with an analysis of the ideological and scientific premises of Karl Gösta Gilstrings's collection. In addition, the article aims to highlight and discuss the working method of such an analysis.

In the following discussion and analysis, I begin by outlining the theoretical framework of the article, followed by descriptions of Karl Gösta Gilstring, his collection and of one of his informants, Carl Nelson. I then proceed to a description of how I have worked with the collection. Thereafter follows the analysis of how places are depicted in stories by Carl Nelson. 
In the article, stories are defined as performances, meaning that stories in both written and oral form are action that is framed, presented and highlighted (Ryan 2004: 8, Schechner 2013: 28). The analysis addresses questions of how and when a story is performed and for what purposes.

There are many reasons for concentrating the analysis on stories: Primarily, stories are considered containers of condensed meaning, offering themselves as flexible communicative tools that are useable in different ways for different purposes. Through the use of stories, tellers can present themselves, argue with or against issues that are important to them, and construct themselves as heroes, victims, sufferers etc. This perspective on stories presupposes a connection between form, content and meaning. The style, structure and form of a story are considered resources for knowledge about social and cultural conditions (Nylund Skog 2012). In addition, they function as signals that give meaning to content for the listener or the reader (Arvidsson 1999: 196). This means that there is always a tension between what the teller can achieve by telling a story and what is required of a teller in order to be believed.

Secondly, since stories are different from other forms of communication, they offer the researcher gateways to processes where meaning is created and maintained. Thirdly, many genres of stories have long histories and traditions, which means that the researcher can gain access to how meaning making is placed in layers of histories. In conclusion and simply put, stories are always told or written for a reason and it is the researcher's task to explore these reasons and how they are embedded in, and part of, processes of communication.

Despite their physical existence, places are also socially and culturally constructed, and emotionally connected to the people inhabiting them, or telling about them. Places offer guidance and steadiness, make us remember and recognize ourselves and tell us who we are by showing us where we are (Povrzanović Frykman 2001: 128, Heimo 2006: 50). Place is therefore understood not only as a "thing in the world", but also as an important way of understanding the world (Cresswell 2015: 10). In this article, the analysis focuses on how the geographical places are depicted and transformed in stories and become new (or at least different) places. With inspiration from discussions on how the local is connected to the global and how space is transformed into place, places are regarded as made by histories of movement and travel, connected and created by stories (Massey 2007 and 2010). In other words, places are made meaningful by stories, and consequently, the same geographic place represents a variety of histories and layers of meaning (Farahani 2007: 38, compare Hall 2002: 242). 


\section{The Collector and his Little Congregation}

Karl Gösta Gilstring is described as a warm-hearted priest, an enthusiastic teacher and a devoted collector of folklore. He was born in 1915 in Östergötland, took his high school diploma in Linköping in 1934 and was ordained in 1941. By the time of his retirement in 1980, he had spent a total of twenty-two years as a priest and more than a decade as a high school teacher. During all these years, he spent his free time working on the folklore collection and he continued this work until his death at his desk in 1986. Karl Gösta Gilstring was married and had one daughter and two sons (ULMA 34 838). Gilstring was awarded an honorary doctorate at Uppsala University in 1975 and in 1985 he received a prize from the Royal Gustavus Adolphus Academy for Swedish Folk Culture, for his "remarkable collection of Swedish folklore collected during more than fifty years of work". The same year he was awarded a scholarship as "our country's most diligent folklore collector" (ULMA 34 838).

It is no coincidence that Gilstring's collection was donated to the Department of Dialectology and Folklore Research in Uppsala (DFU), the former Institute of Dialect and Folklore Research in Uppsala (ULMA). Gilstring's cooperation with ULMA started in the 1940s when he was working with Professor Åke Campbell on the Atlas of Swedish Folk Culture (1957). Gilstring also studied folklore in the 1950s under Dag Strömbäck, the former director of ULMA and Professor of Nordic and Comparative Folklore Research, and he wrote his licentiate thesis at the Department of Religion and History, tutored by Professor Carl-Martin Edsman (ULMA 37 313).

In a letter dated 1 December 1970, Gilstring wrote to his former tutor Edsman about how he came to start his collection of folklore: "I was in high school and had been at home in Hof for my grandmother's funeral. She carried the past of Östergötland, as few did, born in 1851 in Biskopsberga, Allhelgona Parish, close to Skeninge. From that moment I decided to collect what I heard" (1 December 1970, ULMA 34 838). Gilstring knew that the time was a "few minutes before twelve" and that the last of the people who held the oral tradition soon would be dead, as the local newspaper Vimmerby tidning wrote (17 November 1984). Gilstring's aim was to collect and save everything that could be saved, before it was too late.

Gilstring's focus of interest required large amounts of material and his aim was to document all aspects of folk life and tradition (Lilja 1991: 91, Lindqvist 1993: 74, ULMA 37 313). He regarded himself as an explorer, doing necessary pioneer work in parishes that until that time had been blank spots on the map of folklore (Lindqvist 1993: 72). Articles about Gilstring accentuate his historical knowledge and interest in the past (ULMA 34 838). Comments on his lack of interest in everything new or modern are also to be found, as well as criticism of 
his outmoded research methods (ULMA 37 313). To begin with, Gilstring shared his interest in heritage, diffusion and the fear of losing traditions of the past with many, but by the 1960s, the discipline of ethnology shifted interest towards the present time and cultural processes, and many researchers abandoned working with folklore collections such as the one made by Gilstring (Dundes 1986, Lilja 1991: 90, Lindqvist 1993: 65-66).

The basis for Gilstring's collection was in the network of approximately 700 informants with whom he worked over the years. He wrote about ten letters every day to these people, who were spread all over Sweden, Åland, Finland, and Swedish North America. Gilstring required that the people he engaged with should be born before 1920. He got hold of them via appeals in papers such as Kvällsstunden and Svenska Amerikanaren Tribunen (Lindqvist 1993: 70-71). ${ }^{4}$ Gilstring called his informants his "little congregation" and was very involved in their lives (ULMA 37313 ). In a letter to his "dear friends", he thanks them for all they have done for him and for the science of folklore (26 August 1958, ULMA 34 838), and in a letter to his family as early as 1953, he writes that the informants are his friends. They have stood by him and have given him the human community that has meant "the most" to him (4 September 1953, ULMA 34 838).

\section{The Collection of Answers to 3,000 Questions}

In order to understand and work with Karl Gösta Gilstring's collection, it must be placed within the ideological and scientific framework of the time. This framework had taken form by the end of the nineteenth century and was being practically implemented during the first decades of the twentieth century. This was the epoch of inventory and mapping, and the explorer of the old folk life and tradition joined the group of scholarly representatives who made inventories and collected large amounts of material, categorizing them through methods for achieving scientific knowledge (Gustavsson 2014: 41). Theories from the natural sciences were transformed into methods for the science of folklore, which in many respects was a young science striving to be regarded as serious. It was a question of collecting evidence, of rewriting, categorizing and placing data on maps (Löfgren 1995: 141, see also Ekström in this issue).

Karl Gösta Gilstring had a battery of 3,000 questions that fell into approximately twenty categories, based on various topics, which were also the basis for the chapters in his parish collections (Lindqvist 1993: 66). The material was also divided into different headings, such as the year, life, work and rest, sickness and health, sayings and proverbs, and play and pleasure (ULMA 34 838). Although Gilstring's questionnaires are characterized by his own personal and informal style, the questions are detailed and have much in common with questions from the archives to which he contributed (Lindqvist 1993: 67-68). This 
is the case both in the more generalized questionnaires that were published in the weekly press mentioned previously, and in the questionnaires that he sent to his informants. Gilstring also sent out circular letters with questions. On November 8 1960, for example, he wrote to his "friends" in the USA and Canada, wondering how they "had it with water-wheels and other memories". He added that he was grateful for the opportunity to return once more with questions (ULMA 34 838).

In his role as researcher, Karl Gösta Gilstring assessed the letters he received and transcribed the parts that he found interesting. In this work, he was primarily guided by the methods used by ULMA and other folklore archives during the first decades of the twentieth century. As previously mentioned, Gilstring contributed to the Atlas of Swedish Folk Culture, a project in which traditions and customs were placed on maps. The working methods of this project had high scientific value in the 1930s and 1940s; the purpose was to show the diffusion of geographical similarities and differences across the country (Skott 2008, Lilja 2012: 13). In a speech in 1938, the head of the board of the archive, Professor J.A. Lundell, captured the basic ideas of these methods. The speech was given in honour of the director of ULMA, Professor Herman Geijer, on his retirement.

Then the information must be scrutinized and its content checked. Gaps should be filled through new questions. Then this material, in order to become accessible to science, must be registered in detail, to a large extent rewritten on slips of paper, which thereafter fills boxes and cupboards. This needs to be done soon: new forms of old culture are breaking in and creating confusion, only the oldest are still faithful bearers of older local forms of language and inherited wisdom. When these old men and women pass the border into the unknown land, we will have no answers to our questions (Lundell 1939: 7). ${ }^{5}$

In accordance with these methods, Gilstring rewrote parts of the letters that he considered valuable and made excerpts for each category of content. It required special skills to determine what should be kept and collected. Among other things, it was a matter of distinguishing between popular and learned, oral and written, genuine and spurious, as well as primary and secondary. What was left were the ideal and typical descriptions in the form of clear-cut categories that were easy to characterize and distinguish (Lilja 1999). When this work was done, Gilstring put the excerpts into binders according to geography and content. In that manner, he created a series of secondary sources. 


\section{With Roots in the Stony Soil of Småland}

Carl (Charles) Nelson was born 1878 in Western Lillaverke, Oskar Parish, as Karl Oskar Nilsson. He emigrated to the United States of America in 1896, joining the more than one million other Swedes that left the country for the USA between 1830 and 1930. Carl Nelson made only one short return visit to Sweden in 1900, and thereafter spent the rest of his life in the USA. In 1918, he married his cousin Hilma, with whom he lived in Manistique, Michigan, until his death in 1969. In Gilstring's collection, Carl Nelson has number 92:1 and there are 2166 excerpts in his name made by Gilstring (ULMA 34 838: 92: 1).

The correspondence between Gilstring and Nelson began in 1960, when Gilstring had an advertisement to which Nelson responded. The correspondence between them was intensive, especially during the years 1962 and 1966, with about 40 letters from Nelson each of these years (DFU 40 265: 282). In the archive, there are 285 letters from Nelson to Gilstring, and even though not all the letters from Gilstring to Nelson have been kept, there are 318 of them left in the collection (DFU 40 265: 284).

Carl Nelson became an important informant to Gilstring, not only because he was a diligent writer or because of his literacy, and "knowledge of humans and old Swedish traditions", but mainly because his roots went deep in the stony soil of Småland (DFU 40 265: 284). Gilstring repeatedly mentions that Nelson, after he emigrated, returned to Sweden only once and therefore, he argues, Nelson's memories belong to the nineteenth century and reflect life as it was lived during those days. In his description of Nelson, Gilstring carefully describes what he calls the Big Agebo Family, from which Carl Nelson and his wife Hilma originated. They both came from the same "root of a widely branching family tree". Gilstring writes that in this family "son after father have ploughed the soil as long as we can follow the family's destiny" (Svenska Amerikanaren Tribunen, 4 July 1973).

In addition to the deep roots in the stony soil of Småland, Carl Nelson grew up with three mothers, namely his mother, his grandmother and his great-grandmother. The later, called Old Ingrid, was born in 1800. According to Gilstring, in her childhood she had been able to meet people that in their turn met people born in the seventeenth century. Old Ingrid lived until 1892 and Gilstring writes that Nelson remembered a lot from her (DFU 40265: 284, ULMA 34 838).

On several occasions, Karl Gösta Gilstring certifies that Carl Nelson gives a true and genuine picture of Oskar Parish in the nineteenth century and earlier. Gilstring also asked Nelson whether his visit to Sweden in 1900 had affected his memories from before the emigration, and if his social life with Swedes in Manistique had changed his views of his childhood in Sweden. The answer from Nelson is NO, Gilstring writes, and argues that the collection from Nelson testifies to how ductile the memory is, since it can "keep safe and intact the impressions from childhood and early youth" (DFU 40 265: 284, ULMA 34 838: 92: 1). 
In a letter to Gilstring dated June 8 1967, Nelson describes how his memory works.

You ask me how I can remember things from my childhood. In short, I can say that I have a good head for remembering. Yes, but what is a good head for remembering? For me there seems to be a phonographic record that has registered every occasion in my life. There is also colour television on that record. So when I am asked about something that has happened, a certain time or place and how something happened [...] I see and hear what happened then and there. It might sound a bit funny, but that is how it seems to be. The human brain is a marvellous archive that can hide all those events that have taken place in a human's life and we can enter and call up whichever record of our lives we want to study. The human does not come from the monkey (DFU 40 265: 282: 255). ${ }^{6}$

Here it becomes clear that from Nelson's point of view, it is not entirely about his roots in the soil of Småland, but also about his unique "head for remembering". Nelson was deeply religious and belonged to the congregation of Jehovah's Witnesses. From this quotation, we can see that he was sceptical of evolutionary ideas that claimed that humans originated from monkeys. In other letters, he protested against female clergymen and priests, defended legalized prostitution and worried about the dangers of modernity.

As mentioned earlier, Gilstring was not the only one holding on to the thoughts of the time which argued that modernity was destroying and changing original traditions and customs. From this quotation, it seems that Nelson too, albeit in his own way, agreed with Gilstring about the danger of heritage disappearing. In other words, Nelson fulfilled all the criteria of an excellent informant of the time. His deep roots in the stony soil of Småland, the undestroyed and unaffected memories and the direct connection to a specific place gave his statements authenticity and legitimacy. The three mothers added extra historical depth that Gilstring found valuable and motivated him to thoroughly investigate Nelson's family relations and place them geographically within Oskar Parish.

\section{Getting to know the Men and the Collection}

From this first part of the article, many aspects of my working methods have become visible; for example, I have counted the letters of each writer and organized them chronologically. Before that, I spent several years working with similar material and a few years getting familiarized with Karl Gösta Gilstring's collection. As previously mentioned, the collection is large, and initially it gave the impression of being well organized with the properly labelled blue binders and tables of contents. 
However, this orderly system only concerned the final excerpts that Gilstring made from letters and recordings. The unfinished excerpts and manuscripts, the many drafts of different parish collections, of portraits of informants and of articles and questionnaires for newspapers, were - together with the thousands of letters - left in poorly marked boxes, binders and envelopes. To get an idea of the character of this material and of Karl Gösta Gilstring's working methods, I have spent several weeks of "fieldwork" in the archive. In combination with reading literature about the formation of the archive and of theories and methods during Gilstring's active period, I have gained some rudimentary knowledge of his collection. As I argue above, I regard such knowledge as necessary when analysing the letters.

When choosing which of the many informants to concentrate the analysis on, it has been a question of both method and coincidence. In my experience, it is an analytical advantage to have an empirical body of material that is rich and clearly defined by theme, form or, as in this case, person. Therefore, I searched for an active informant in Gilstring's collection, preferably including (1) letters both to and from Gilstring, (2) letters as well as recordings from the same informant, (3) where Gilstring had made many excerpts and (4) during a period of ten years in the 1960s, when Gilstring seems to have been most active. In Carl Nelson, I found such a person. In addition to being an active informant, there are letters from both him and Gilstring in the collection. Nelson was also interviewed in 1967 by Barbro Klein (Sklute at the time), who supervised my doctoral thesis and who happened to donate the recordings with Nelson as research material to the archive some time prior to her death in 2018 (bd 11 420-22). To make the choice even easier, a sound technician digitized the old recordings. With these and the typewritten letters, there was no argument against concentrating on Carl Nelson.

When the decision was made, I started out by searching the archive to make sure I did not miss other files on Carl Nelson. I wanted to ensure that I knew of all the available material concerning Nelson. There was nothing except the letters and the recording. The letters were in three different boxes, presumably mirroring where in the working process Gilstring had been when he died in 1986. Thereafter, I organized the letters chronologically in order to gain insight into how their correspondence was established and changed over the years. I also read a couple of letters from each year and tried to match some of Gilstring's questions with some of Nelson's letters with answers. This was not as easy as one might think; on the one hand, Gilstring himself had two overlapping systems of numbering the letters and often repeated questions. Nelson, on the other hand, did not answer directly. He could either spread his answers over several letters or answer questions from several of Gilstring's letters in just one of his.

After some time, when I had an idea of the character of their correspondence, I searched Nelson's letters for stories of any kind. I would like to point out that I use the term story in a very broad sense, including all oral and written forms of storytelling used in communication, for example, personal experience narratives, 
reports, jokes, anecdotes and legends. For the teller, they serve as flexible tools useable in different ways for different purposes (Bauman 1992: 58). This means that a story framed as a folk tale is used and understood differently than one framed as a legend or a personal experience narrative.

I found that Nelson had an extensive repertoire, dominated by some themes and stories. I have concentrated the analysis on such stories, and in the following discussion, I will show how the stories are thematically and geographically linked, as well as organized by meaning and message.

\title{
Tales of Caves and Mountains
}

In a letter to Karl Gösta Gilstring, dated May 31 1967, Carl Nelson writes about a cave in Kroksmåla. Gilstring has probably asked him a question that he tries to answer because the letter begins with the words "Thank you for your letter of 25 May. You speak of caves" (DFU 40 265: 282: 254).

\begin{abstract}
There was a lot of talk about a cave "underground passage". It was in Kroksmåla. The opening was on the border of Krokstorp and Lillaverke, by the southern end of the Krokstorp Lake. The saga tells that there were 7 farmers that tied together 7 ox reins to a line and went into the cave as far as the line allowed. They did not dare to go further. They also said that a dog had gone into the cave but it never came out. They heard it barking far away in the cave. There was a lot of talk about that cave in Lillaverke when I was there, but nobody dared to go in there. That is the only cave I have heard about in that neighbourhood (DFU 40 265: 282: 254) ${ }^{\text {? }}$
\end{abstract}

According to Carl, this is a saga (folk or fairy tale) about seven farmers that tied together seven ox reins. None of them dared to let go of the reins and venture further into the cave. Carl does not say why they wanted to enter the cave. Maybe there was a treasure inside or perhaps they wanted to fetch the dog that was in there. The introductory part of the story has much in common with a type of folk legend ( $\mathrm{T}$ 100) where the events take place in a subterranean passage between a monastery and another building (af Klintberg 2010: 354). In Carl Nelson's story, the place-the underground passage or cave-forms the starting point for the tale of the seven farmers. Nelson writes that it is the only cave that he has heard about in that neighbourhood, meaning Oskar Parish.

Carl Nelson's birthplace, Western Lillaverke, is situated in Oskar Parish in Kalmar County, a region with forests and small lakes that is criss-crossed by the Hagby river vein. The name Lillaverke comes from the word verke, which is a catching device for fish. Perhaps the name has its origin in one such device in the Hagby river vein (Nybrokunskap). That Lillaverke is located in an area with 
many forests and lakes is often evident in Nelson's stories. This saga takes place in Kroksmåla, which is situated one and a half kilometres from Western Lillaverke, close enough so that what happened there is talked about in Western Lillaverke.

I have not found any more stories of the cave in Kroksmåla in the letters (or recordings). Stories of the Stacka Mountain, on the other hand, are numerous. The mountain is situated in Svalehult, Madesjö Parish instead of Oskar Parish. This is what Carl Nelson writes in one of the first letters to Karl Gösta Gilstring on 14 March 1960:

This is the saga of Stacka Mountain. There was a Boatswain named Svala. His home was in Svalehult, Madesjö Parish. He was on a long journey in the service of the crown. The ship was in the Pacific Ocean when one day it stopped, and a giant looked over the rail and asked for Boatswain Svala. Svala was brought to the giant (Svala was alarmed). The giant said to Svala "Do not be afraid. Nothing bad is going to happen to you. You know where Stacka Mountain is. I could not stay there and hear the church bells, so I went away, but forgot my dog in the mountain. When you come home, go to the mountain and set my dog loose. He is tied up there in the mountain. Do not be afraid, since as soon as the dog is lose he will run to me. Then you will get all that is in the mountain. There are three barrels of gold and a table that has a golden top and a silver foot. The dog is tied with a golden chain." When Svala came home, he went to the mountain, found the key and went in. However, when he saw the dog, he became so frightened that he ran out and closed the door and threw away the key. Once he got home, he told about what he had seen and the word was spread that there was gold in Stacka Mountain. People came and started digging to find the gold but instead of gold, they got sick. So, it was forbidden to dig there. After some time Svala lost his mind. Stacka Mountain is in Svalehult, Madesjö Parish. (DFU 40 265: 282: 3$) 8$

Carl Nelson classifies this story too as a saga, even though it has the characteristics of a legend. In contrast to a saga, which takes place in a distant and unrealistic place where magical things happen, Nelson's story is set in historical time and the geographical place where the event occurred is mentioned both at the beginning and at the end of the story (af Klintberg 2010: 13). In this case, there are many similarities between Nelson's story and a folk legend type (J36E) where a giant asks a sailor to release a dog that is left in the mountain where the giant used to live (af Klintberg 2010: 162). However, the ending of Carl Nelson's story differs from the legend type where the sailor succeeds in letting the dog free and is rewarded with the giant's treasure. 
By framing the story as a saga, Carl Nelson assures the reader that he does not believe the story to be true. However, he both begins and ends the story by mentioning the name of the place. In that manner, he creates authenticity not by telling about something that he believes actually happened, but by placing the story in a physical landscape. And indeed, Svalehult exists, as does the parish and the church called Madesjö. There is also a long line of seamen from Svalehult who have taken the name Svala. In that way, they have carried the name and the place Svalehult with them around the world.

Here it is obvious that places do not only remind us about events in the past. In stories, they also become evidence for the authenticity of what is told and give authority to the teller (Johnstone 1990: 126-135, Heimo 2006: 50). The mention of Svalehult also transforms the landscape of Carl's childhood into a magical place of tales and wonder. However, even if Carl Nelson did not believe that there was a giant living in the cave, he believed other aspects of the story to be true. The first time he told the story to Barbro Klein, he concluded it by remarking that the boatswain became insane and that that was true since Nelson's father knew the boatswain (bd 11 420).

In her thesis on legends and folk belief in New Sweden, Barbro Klein remarks that the informants often raised the issue of belief and this sometimes resulted in animated conversations between informants (Klein 1980: 20). This is exemplified by Nelson's remark that his father knew the boatswain. The topic is also raised in connection with yet another version of the story about Svala told by Carl Nelson and his brother during the interview. Barbro Klein then asks the brothers who told them the story. Carl Nelson's brother claims to have heard it from their father, but Carl Nelson objects and argues that it was told and believed by almost everyone in the old days. Yet, he also concludes this version of the story by referring to the place: "It was not far from Lillaverke. It was by Svalehult. And Svalehult bordered on Lillaverke" (bd 11 421).

The giant of the tale has fled from Stacka Mountain since he could not stand hearing the church bells ring. This is a common motif in stories about giants and their relatives, the trolls (af Klintberg 1977: 26). In one perspective, the tale about Stacka Mountain captures Christianity's victory over old superstition, a theme to which Carl often returned. It is interesting, though, that this legend type (J63E) is placed under the heading Resistance against Christianity, but when Carl Nelson uses the type, he transforms the message into the opposite. In an orally performed version, Carl introduces the tale of Stacka Mountain with the words: "The story was. It was during the time when Christianity came to Småland" (bd 11 420).

It has been claimed that it is easier to recall and depict a journey with the help of places rather than with dates and time. In such a perspective, memory is spatially and not temporally organized (Heimo 2006: 53). One reason for this 
could be that time has passed while places still exist, even if only in memory, as is the case with Nelson. He has not visited the places he talks about in over sixty years. He also performs the story in a place far away (Kaivola-Bregenhøj 2006: 34). From this perspective, the places and events are more important than time, which in this case Nelson loosely defines as the time when Christianity came to Småland (Johnstone 1990: 130-131; Heimo 2006: 52; Nylund Skog 2012: 55).

It has been noted by many folklorists that exact markers of place are narratively important, especially when it comes to legends (af Klintberg 1977: 12). Barbro Klein writes that by thoroughly describing where something extraordinary took place, the teller attempts to convince the audience that the supernatural events they talk about actually happened in a world that the teller and perhaps the audience are familiar with (Klein 1993: 96). In that respect, the stories do not primarily concern the physical places mentioned or, in the case of Carl Nelson, even his childhood landscape. Carl Nelson says that all he remembers from his childhood and youth in Sweden is poverty and hard work (DFU 40265: 282: 11). Consequently, in his stories, the geographical places in Oskar Parish are transformed into mythological places without geography and, as Klein writes, the outer topography becomes a depiction of an inner condition (Klein 1993: 96). In Carl Nelson's stories, this condition is portrayed as a mythological landscape marked by a romantic longing for a lost and pristine time. In that vein, the places he describes are only present in his stories.

\section{Stories Without Place or Time}

Another aspect that connects to the religious theme of the saga of Stacka Mountain is that a person who yields to temptations gets into trouble. In the tale, those who search for the giant's treasure become insane and Svala loses his mind (bd 11420 ). The giant appears to be reasonably nice. He repeatedly assures Svala that he does not have anything to fear and that he will be richly awarded if he helps the giant. With the story, it is as if Carl Nelson urges the listener and reader not to be fooled by promises of gold and treasure. According to the story, such promises lead away from God to sickness, insanity and misery. The presence of the dog in this story, as well as in the one about the cave in Kroksmåla, strengthens this interpretation; in many folk legends, the devil appears in the shape of a dog (af Klintberg 2010:214). If we interpret the dog in the saga of Stacka Mountain as the devil, to succeed in letting the dog loose is equal to letting the devil loose.

The thematic (and religious) connection between the devil and temptation is also present in another story told by Carl Nelson on two occasions during the interview with Barbro Klein and written twice in letters to Karl Gösta Gilstring. Briefly, the story is about a poor bookkeeper that falls in love with a rich girl 
and willingly sells his soul to the devil in order to win the young girl's heart and marry her. ${ }^{9}$ The bookkeeper signs a contract with the devil who promises him twenty years of happiness with the girl. They sign the contract with blood and the bookkeeper puts it in a drawer. The devil keeps his part of the deal and soon the bookkeeper learns that he has inherited a fortune from a distant relative and can marry the girl. They live happily and by the end of the twenty years, the bookkeeper looks for the contract but cannot find it. He becomes ill and dies. After his death, the contract is found behind the drawer, but whether the devil actually took the bookkeeper's soul is "never told" (DFU 40 265: 282: 280).

This story also seems inspired by a well-known folk legend (L32) where a contract signed with the devil is placed in a keyhole of a church (af Klintberg 2010: 220-221). On the other hand, the most central aspects of Carl Nelson's story are not part of this legend type. One such aspect that is clearly depicted and recurrent in all versions concerns the signing of the contract. In the first version from 14 March 1960, Carl writes that "Satan tore a small hole" in the hand of the bookkeeper so he could sign the contract "in his own blood" (DFU 40 265: 282: 3). In the second written version from 30 June 1969, Carl writes that Satan took the hand of the bookkeeper, tore a hole and said: "Here you have ink! Now write!" (DFU 40 265: 282: 280). During the interview, Carl Nelson says that the devil and the man "made a contract and there was a scar here in the hand so the blood ran" (bd 11 420). In every version, Carl Nelson also emphasizes that the man and the girl were happy, that the man put the contract in the drawer and that it was found after his death. However, it is only in one version of the story that the poor man is a bookkeeper, namely, the version that Carl Nelson wrote in 1969 in response to a question from Gilstring about the devil. Although the story seems inspired by one or more folk legends, the theme of man selling his soul to the devil is also a folk tale motif (M211 in Thompson 1957: 39). In that manner, Nelson's version of the story appears to be a mix of several folk genres, where the tearing of a hole to get access to the bookkeeper's blood is central.

The reason why Carl repeated this story, and in the way he did it, is probably because it concerned issues valuable to him. With stories, we can express topics and viewpoints that are important to us without saying so explicitly (Nylund Skog 2005). I think this is the case with the story of the bookkeeper who sold his soul to the devil. The story delivers several intertwined messages of importance to Carl Nelson. It is obvious that the story discourages people from signing a contract with the devil, a message that is to be symbolically understood. The story deals with religious issues and warns the listener not to be fooled or lured by promises of riches and happiness, since it all comes at cost. The moral of the story could also be that poor and rich people should not marry or that a person should not marry under false premises. The man was poor and perhaps Carl Nelson argued that the 
girl should have accepted him without the inherited fortune. Another message is to humbly bow before God and accept what life offers. Perhaps Carl Nelson conveyed with the story that twenty years of happy marriage always comes at a price. No matter what the message of the story is, it offered him an opportunity to perform an entertaining piece of important information.

I find it interesting that this story in the style of a folk tale is not located in a place. Nor are the characters or the surroundings described in any detail (Gustavsson \& Palmenfelt 2018: 15). The story does not convey when and where the contract is signed. In one version Carl Nelson says that the man inherits money from an uncle in Brazil (DFU 40265: 282: 280), but that is all we get to know about the places of the story. During the interview, Barbro Klein repeatedly asks Carl Nelson questions about who told the stories and where they were told. Concerning the story about the man who signed a contract with the devil, Nelson answers that it is "the same again, as with all other stories". They do not have "place or time" (bd 11 420). Perhaps this lack of time and place makes the story especially interesting and repeatable. As with folk tales, it does not matter for the moral of the story whether it is about people in America or in Oskar's Parish in the eighteenth, nineteenth or twentieth century. In that respect, the story has much in common with a folk tale and is portable in character. It offers Carl Nelson an opportunity to entertain while recreating the magic landscape of his youth and simultaneously expressing moral standpoints.

Earlier, I mentioned that Gilstring rewrote parts of the letters that he found valuable and made excerpts for each category of content. In that manner, Gilstring has rewritten the story of the bookkeeper who signed a contract with the devil from Carl Nelson's letter, word for word (DFU 40 265: 282: 280). However, he apparently had trouble categorizing its content in relation to his system and left it without a heading. Maybe it was Carl Nelson's remark that there were many stories of people who sold their souls to the devil that convinced Gilstring to make the effort of rewriting the story, even though stories like this did not automatically fit into his system of categories. It is obvious from his collection that it was much easier for him to categorize short remarks and direct answers to questions (ULMA 34 838).

The first version of the story about the man who sold his soul to the devil was written by Carl Nelson directly after the tale about Stacka Mountain (DFU 40 265: 282: 3). As we recall, one theme of that story was that those who were tempted by promises of gold and searched for the treasures in Stacka Mountain became sick. In the story about the bookkeeper who sold his soul to the devil, it leads to death, although after twenty years of being happily married. The stories are also connected by the theme of the devil since he was often pictured as a black dog (af Klintberg 1977: 35). Perhaps it was the devil who was captured in the cave at Kroksmåla and trapped in Stacka Mountain. In that vein, it is not only places that connect times and stories, certain topics and themes can do the same job. Among 
others, the folklorist Katharine Galloway Young has demonstrated how stories are thematically connected and constructed in such a way that they serve as context to one another, as well as explaining and highlighting the moral messages (Young 1986, Nylund Skog 2005: 165).

\section{Concluding Remarks}

By way of introduction, I wrote that we imagine that there is a connection between a place and those living there. In Karl Gösta Gilstring's collection, this supposition forms the theoretical foundation. The collection presupposes that a person's place of birth gives that person her or his identity, as well as offering a home, a heritage and belonging (Ahmed 1999, Taylor 2012: 51).

In Gilstring's collection, Carl Nelson represents Oskar Parish even though Nelson only lived there until he was seventeen and seldom referred to the whole parish in his stories, but rather to the village of Western Lillaverke and other parishes. This fact seems to further motivate Gilstring to investigate Nelson's family relations, to include Nelson's wife in this investigation and to connect them both to what he called the Big Agebo family, which was spread all over the parish.

The reason why Gilstring changed the spatial references of Nelson's lettersmaking it seem as if they spoke of Oskar Parish rather than Western Lillaverkeprobably had to do with the way his collection was organized. Whether or not a parish was complete depended on whether Gilstring had answers to all of his 3,000 questions. When he had collected enough excerpts and organized them in relation to this framework, he considered the parish collection finished. In that manner, some parish collections contain contributions from many persons, while others, such as the one from Oskar Parish, are made of letters from only one person.

To summarize, when contributing to the collection, Nelson, like all the other 700 in Gilstring's small congregation, came to represent a place in Sweden. Thereby, he and the others also came to represent traditions and customs in a specific geographical area. The ideological and scientific premises for the collection demanded that a person's customs and traditions, in order to be understood as such, needed a geographical place of origin.

Initially, I wrote that Gilstring argued that he did not think that there was a parish in Småland or in the country as a whole, whose traditions were as thoroughly depicted as Oskar Parish thanks to the manuscript made from Carl Nelson's letters (ULMA 34 838: 92). The many excerpts that Gilstring made from the correspondence with Carl Nelson are of course an important source of 
information of how Carl Nelson remembers customs and traditions and retells stories from his life as a child in Småland at the end of the nineteenth century. However, as the analysis in this article shows, the stories in Carl Nelson's letters do not primarily convey traditions and customs of Gilstring's interest. Instead, they depict a mythological landscape recreated by the emigrant Carl Nelson in his home on the outskirts of Manistique, Michigan.

In this article, I have demonstrated that the correspondence between Carl Nelson and Karl Gösta Gilstring can be analysed in order to gain knowledge of how stories serve to accentuate and highlight issues that are important to the teller, as well as of how places are depicted and made meaningful. However, the correspondence is also suitable for analysis of childhood life stories in Sweden at the end of the nineteenth century and of how a folk life researcher such as Gilstring constructed knowledge of traditions and customs of past times. In addition, the letters from Nelson are resources for knowledge on life in America during the 1960s and earlier. In them, he describes his work on the railways, the passages to America from Sweden, his journeys in the new country, as well as his time in Nome, Alaska, in search of gold. Gilstring's letters, on the other hand, describe his family life, his clerical duties as well as his work as a high school teacher. In the letters, he mentions colleagues, relatives and friends. He describes sickness, happiness and struggle. In that manner, the reader learns about the conditions and life of an educated middle-class man in Sweden. In conclusion, for someone interested in cultural processes and life in the first part of the twentieth century, the correspondence between the Swedish American Carl Nelson and the folk life researcher Karl Gösta Gilstring offers an abundant empirical resource.

Susanne Nylund Skog is a researcher at the Institute for Language and Folklore, the Department of Dialectology and Folklore Research in Uppsala, Sweden. She is docent (associate professor) of ethnology at Uppsala University, Sweden, and of Nordic folklore studies at Åbo Akademi University, Finland. She defended her doctoral dissertation in ethnology on childbirth stories at the University of Stockholm in 2002. She has also done extensive ethnographic research on Jewish life in Sweden and on stories told by birdwatchers. With performance and narrativity in focus, she has explored issues such as anti-Semitism, whiteness, intertextuality, masculinity, emotions and materiality. She is currently doing research on archive collections within the project TillTal-Making Spoken Cultural Heritage Accessible for Research funded by Riksbankens Jubileumsfond, the Swedish Foundation for Humanities and Social Sciences from 2017 to 2020 (SAF16-0917:1). Email: susanne.nylund.skog@sprakochfolkminnen.se 


\section{Notes}

1 This article is part of the multidisciplinary and methodological project Tilltal (Tillgängligt kulturarv för forskning $\mathrm{i}$ tal, 'Accessible cultural heritage for speech research'), financed by the Royal Swedish Academy of Letters, History and Antiquities and the Swedish Foundation for Humanities and Social Sciences (Riksbankens Jubileumsfond) from 2017 to 2020 (SAF16-0917:1).

2 Det torde icke finnas någon enskild socken i Småland eller huvud taget i vårt land vars folkliv är så genomgående skildrat som just Oskars socken i Södra Möre genom det manuskript som är helt sammanfogat av Carl Nelsons brevsamling. (ULMA 34 838: 92).

3 In 1914 a research institute for the documentation of dialects and popular tradition was set up in Uppsala, followed by the foundation of a special Folklore Department within the Institute in 1928. Today, the Department of Dialectology and Folklore Research in Uppsala is part of the Institute for Language and Folklore, a Swedish government agency with a focus on dialects, language policy, language planning, names and folklore. The archives of the Institute houses one of Sweden's largest folklore collections. Karl Gösta Gilstring's folklore collection was donated to the archive in Uppsala in connection with his death in 1986.

4 Svenska Amerikanaren Tribunen was a merger of several American paper in Swedish to a weekly paper, published in Chicago from 1936 to 1966. Kvällsstunden is a Swedish independent weekly paper published in Västerås since 1938, where stories describing Sweden in the past are still frequent.

5 Translated from Swedish: Men så måste de upplysningar som inkommer granskas och till sin innebörd kontrolleras. Luckor utfyllas genom nya frågor. Så måste detta material, för att bli för vetenskapen tillgängligt i detalj registreras, till stor del skrivas om på lappar, som sedan fyller lådor och skåp. Detta måste göras snart: nya kulturformer bryter in och vållar stor förvirring, endast åldringar är ännu trogna bärare av äldre lokala språkformer och fäderneärvd visdom. När dessa gamla män och kvinnor gått över gränsen till det okända landet, får vi inga svar på våra frågor (Lundell 1939: 7). 6 Translated from Swedish: Du frågar hur jag kan komma ihåg saker och ting från min barndomstid. I korthet kan man säga det är just ett godt kom ihåg. Ja, men vad gör ett godt kom ihåg? För mig tyckes det vara en phonograf skiva som spelats in varje händelse i mitt liv. Det är också färg TV på den skivan. Så när jag bliver tillfrågad om något som hänt, en viss tid eller plats och hur något hände /.../ (sinne) ser jag, och hör vad som då hände och det hände. Det kanske låter lite lustigt, men så tycks det vara. Människans hjärna är ett förunderligt Arkiv som kan gömma alla de händelser som har hänt i en människas liv och vi kan gå där och kalla för vilket rekord av vårt liv vi vill studera. Människan kommer ej från apan (DFU 40 265: 282: 255). 
7 Translated from Swedish: Det talades mycket om en grotta 'underjordisk gång'. Den var i Kroksmåla. Öppningen var vid gränsen av Krokstorp och Lillaverke, vid södra ändan av Krokstorps sjön. Sagan säger att det var 7 bönder som knöt ihop 7 oxtömmar till ledningslina och gick in i grottan så långt som linan räckte. De tordes ej gå längre. De sade också att en hund hade gått in i grottan men kom aldrig ut igen. De hörde den skälla långt in i grottan. Det talades mycket om den grottan i Lillaverke när jag var där, men ingen vågade gå in där. Det är enda grottan jag hört om i den nejden. (DFU 40 265: 282: 254)

8 Translated from Swedish: Här är sagan om Stacka berg. Det var en Båtsman som hette Svala. Hans hem var i Svalehult, Madesjö socken. Han var ute på långresa i Kronans tjänst. Skeppet var i Stilla Havet när det en dag stannade och en Jätte tittade över relingen och frågade efter Båtsman Svala. Svala fördes fram till Jätten (Svala var förskräckt). Jätten sade till Svala "Var ej rädd. Intet ont ska hända dig. Du vet var Stacka berg är. Jag kunde ej stanna där och höra klockorna, så jag gick därifrån, men glömde min hund i berget. När du kommer hem, gå till berget och lös min hund. Han är bunden där inne i berget. Var ej rädd, ty så fort hunden bliver lös så springer han till mig. Då får du allt som är i berget. Där är 3 tunnor med guld och ett bord som har guldskiva och silverfot. Hunden är bunden med guldkedja." När Svala kom hem gick han till berget, fann nyckeln och gick in. Men när han såg hunden blev han så rädd, så han sprang ut och stängde dörren och kastade bort nyckeln. Kommen hem talade han om vad han sett och det spriddes ut att det fanns guld i Stacka berg. Folk kom dit och började gräva för att finna guldet men i stället för guld blev de sjuka. Så det blev förbjudet att gräva där. Efter en tid miste Svala förståndet. Stacka berg är i Svalehult, Madesjö socken (DFU 40 265: 282: 3).

9 Carl Nelson calls the devil Satan throughout.

\section{References}

Newspapers

Kvällsstunden: Hemmets och familjens veckotidning (1938-): https://kvallsstunden. se/, Västerås: Kvällsstunden.

Svenska Amerikanaren Tribunen (1936-1985): http://www.mnhs.org/newspapers/ swedishamerican/svenska-tribunen, Chicago, Illinois: Swedish American Newspaper Co.

Vimmerby tidning (1884-): http://www.vimmerbytidning.se/, Vimmerby: Vimmerby tidning.

\section{Archives}

The Institute for Language and Folklore, Department of Dialectology and Folklore Research, Uppsala (DFU, former ULMA) 


\section{Culture Unbound}

Journal of Current Cultural Research

Bd 11 420-22

DFU 40265

DFU 40 265: 282:
Recordings with Carl and Hilma Nelson made by Barbro Klein in Nelson's home in Manistique, Michigan, 12-15 April 1967. Karl Gösta Gilstring's collection of letters.

\section{1-285 Letters from Carl Nelson to Karl Gösta Gilstring} 1960- 1969.

DFU 40 265: 282: 3, 14 March 1960.

DFU 40 265: 282: 11, 11 June 1960.

DFU 40 265: 282: 254, 31 May 1967.

DFU 40 265: 282:2 55, 8 June 1967.

DFU 40 265: 282: 280, 30 June 1969.

DFU 40 265: 283 Correspondence between Barbro Klein and Karl Gösta Gilstring 1964-1974.

DFU 40 265: 284

Letters from Karl Gösta Gilstring to Carl Nelson, 19611969.

ULMA 34838 Karl Gösta Gilstring's folklore collection.

ULMA 34 838: 92 Memories from Oskar Parish.

ULMA 34 838: 92: 1 2,166 excerpts made from Carl Nelson's letters by Karl Gösta Gilstring.

ULMA 37313 Summaries of interviews about Karl Gösta Gilstring after his death, made by Eva-Lott Lindqvist 1993.

\section{Literature}

Ahmed, Sara (1999): "Home and Away: Narratives of Migration and Estrangement," International Journal of Cultural Studies, 2:3, 329-347.

Arvidsson, Alf (1999): Folklorens former, Lund: Studentlitteratur.

Atlas över svensk folkkultur (1957): Åke Campbell, Sigurd Erixon \& Åsa Nyman (eds): 1, Materiell och social kultur, 2, Sägen, tro och högtidssed, Uppsala: Kungliga Gustav Adolfs Akademien.

Bauman, Richard (1992): "Genre," Richard Bauman (ed.): Folklore, Cultural Performances, and Popular Entertainments: A Communications-centered Handbook, New York: Oxford University Press.

Cresswell, Tim (2015/2004): Place: An Introduction, Chichester: Wiley \& Sons Ltd.

Dundes, Alan (1986): "Den devolutionistiska premissen i folkloristisk teori," Stockholm: Institutet för folklivsforskning. Also in Journal of the Folklore Institute VI, 5-19.

Farahani, Fataneh (2007): Diasporic Narratives of Sexuality: Identity Formation among Iranian-Swedish Women, Stockholm University: Stockholm Studies in Ethnology 2.

Gustavsson, Karin (2014): Expeditioner $i$ det förflutna: Etnologiska fältarbeten och försvinnande allmogekultur under 1900-talets början, Stockholm: Nordiska museets förlag.

Gustavsson, Per \& Ulf Palmenfelt (2018): Folksagan $i$ Sverige: Berättelserna 3, Stockholm: Carlsson bokförlag, utgiven i samarbete med Vislanda hembygdsförening och Sagobygden.

Hall, Stuart (2002): "Kulturell identitet och diaspora," Catharina Eriksson, Maria Baaz \& Håkan Thörn (eds): Globaliseringens kulturer: Den postkoloniala paradoxen, rasismen och det mångkulturella samhället, Nora: Nya Doxa. 


\section{Culture Unbound}

Journal of Current Cultural Research

Heimo, Anne (2006): "Places Lost, Memories Regained: Narrating the 1918 Finnish Civil War in Sammatti," Annikki Kaivola-Bregenhoj, Barbro Klein and Ulf Palmenfelt (eds): Narrating, Doing, Experiencing: Nordic Folkloristic Perspectives, Helsinki: Finnish Literature Society, Studia Fennica Folkloristica 16, 47-63.

Johnstone Barbara (1990): Stories, Community and Place: Narratives from Middle-America, Bloomington: Indiana University Press.

Kaivola-Bregenhøj, Annikki (2006): "War as a Turning Point in Life," Annikki Kaivola-Bregenhoj, Barbro Klein \& Ulf Palmenfelt (eds): Narrating, Doing, Experiencing: Nordic Folkloristic Perspectives, Helsinki: Finnish Literature Society, Studia Fennica Folkloristica 16, 29-46.

Klein, Barbro (1980): Legends and Folk Beliefs in a Swedish American Community, Diss. Bloomington, 1970.

Klein, Barbro (1993): "Folkets röst: Svensk-amerikanska insändarbrev och folklorens betydelser," Nord Nytt, 52, 85-97.

af Klintberg, Bengt (1977): Svenska folksägner, Stockholm: Bokförlaget Pan / Nordstedts.

af Klintberg, Bengt (2010): The Types of the Swedish Folk Legend, Folklore Fellows' Communications 300, Helsinki: Academia Scientiarum Fennica

Lilja, Agneta (1991): "I den nationella odlingens tjänst: Dialekt- och folkminnesarkivet i pressen under sju årtionden," Kristina Hagren \& Agneta Lilja (eds): Sagt och gjort: Vänskrift till Wolter Ehn och Rune Västerlund, Uppsala: Dialekt- och folkminnesarkivet, $88-103$.

Lilja, Agneta (1999): "Den ideala uppteckningen i klassisk etnologi," Ulrika Wolf-Knuts (ed.): Vägen till arkivet, Åbo: NNF Publications, 21-48.

Lilja, Agneta (2012): "Ella Odstedt - liv och gärning," Ella Odstedt, Varulven i svensk folktradition, Stockholm: Malört förlag, 8-17.

Lindqvist, Eva-Lott (1993): "Väktare mot glömskans rike: En presentation av Karl Gösta Gilstrings folkminnesinsamling," Svenska landsmål och svenskt folkliv, 116, 63-78.

Löfgren, Orvar (1995): "Sakletarna: Om det materiellas betydelse i etnologin," Åke Daun (ed.): Ting, kultur och mening, Stockholm, Nordiska museets förlag, 137-160.

Lundell, Johan August (1939): "Herman Geijer och Landsmålsarkivet i Uppsala," Meddelanden från Landsmålsarkivet i Uppsala, 5-10.

Massey, Doreen (2007/1994): Space, Place and Gender, Cambridge: Polity Press.

Massey, Doreen (2010/2005): For Space, London: Sage.

Nybrokunskap (2018): http://www.nybrokunskap.se/ (accessed 17/9/18).

Nylund Skog, Susanne (2005): "Hisnande historier och talande tystnader: Berättelser i frågelistsvar," Charlotte Hagström \& Lena Marander-Eklund (eds): Frågelistan som källa och metod, Lund: Studentlitteratur, 149-168.

Nylund Skog, Susanne (2012): Livets vägar: Svenska judinnors berättelser om förskingring, förintelse, förtryck och frihet, Uppsala: Institutet för språk och folkminnen.

Nylund Skog, Susanne (2017): "Brev och belägg i jakten på folkminnen: Den vetenskaplige samlaren," Kulturella perspektiv, 26:1, 36-46.

Povrzanović Frykman, Maja (2001): "När våldet tar plats," Kjell Hansen \& Karin Salomonsson (eds): Fönster mot Europa: Platser och identiteter, Lund: Studentlitteratur, $125-165$.

Ryan, Marie-Laure (2004): Narrative across Media: The Languages of Storytelling, London: University of Nebraska Press.

Schechner, Richard (2013/2002): Performance Studies: An Introduction, London: Routledge.

Skott, Fredrik (2008): Folkets minnen: Traditionsinsamling i idé och praktik 1919-1964, Göteborg: Institutet för språk och folkminnen.

Taylor, Stephanie (2012/2010): Narrative of Identity and Place, London: Routledge.

Thompson, Stith (1957): Motif-Index of Folk-Literature, Volume Five, L-Z, Bloomington: Indian University Press.

Young, Katharine (1987): Taleworlds and Storyrealms: The Phenomenology of Narrative, Dordrecht: Martinus Nijhoff Publishers. 


\title{
A Picture is Worth a Thousand Words. On Photographs, Talking Contexts and Visual Silences
}

\author{
By \\ Mattias Frihammar
}

\begin{abstract}
This paper's point of departure is that historic silences are socially constructed and culturally productive, and that photographs in archives participate in the creation of historical silences despite, or maybe thanks to, their convincing depicting qualities. In this essay, photographs from three occasions have been studied in detail in order to elucidate different kinds of visual silences. The occasions are i) a funeral where it is the photographer's own mother that is being buried, ii) a funeral where the coffin is covered in a draping with a swastika, and iii) a royal funeral. Adopting a self-reflexive outlook, the purpose of this essay is to suggest a few possible ways of addressing silences that can occur when the presumptions of a beholder meet the image content of a photograph from the past. The three examples show that the concept of visual silence can be applied in different ways. In the first example, the technical and artistic shortcomings are interpreted as silencing components, which can convey information. In the second example, the (to a contemporary beholder) provocative silence around the historically charged symbol of a swastika becomes an analytical resource in its own right. The last example illustrates how a lot of information can compose such a dominant narrative, that it silences other stories.
\end{abstract}

Keywords: Visual silence, Photographs, Archive, Gunnar Lundh, Funeral, Media event.

Frihammar, Mattias: "A Picture is Worth a Thousand Words. On Photographs, Talking Contexts and Visual Silences", Culture Unbound, Volume 12, Issue 1, 2020: 217-232. Published by Linköping University Electronic Press: http://www.cultureunbound.ep. $\underline{\text { liu.se }}$ 


\section{Introduction}

Photographs have been said to be storytellers and memory mediums so persuasive that next to them, in the words of Allan Sekula, "all other forms of telling and remembering begin to fade" (2003:448). The technique in which an exposition of light leaves a trace on a photographic plate gives the impression that "the pencil of nature" captured the situation (Burke 2006:22). In this essay, I want to reflect on photographs as sources of cultural history knowledge and how they despite, or maybe thanks to, their supposedly unblemished depicting qualities, participate in the creation of historical silences.

Departing from the view that silence is "an integral part of processes of remembering" (Manson \& Sayner 2018:1), I want to test the concept of visual silences. How can the concept be understood? In what contexts does it appear? How can it be interpreted? The choice of concept is intentional. The search for silence will hopefully stress narrative aspects of visual mediums. Focusing on silence instead of, for example "lack" or "absence" implies that photographs, in singular but even more so as collected archives, contribute to the construction of historic narratives.

I understand visual silences as a result of the confrontation between the content of an image and the presumptions of a beholder. This calls for a self-reflexive approach. More specifically, it is the researcher's, meeting with, and interpretation of photographs that are of interest. After all, it is often through the work of researchers, such as myself, that photographs in an archive are found, highlighted, interpreted and explained before they become available to a museum audience.

The point of departure for this essay is my readings of a sample of photographs from the photographic archive of the twentieth century photographer Gunnar Lundh, which today is a part of the Nordic Museum archive in Stockholm. The motifs that the essay focuses on are thus part of a museum's collection. However, before they became museum items, they had travelled through a range of contexts. They first appeared as real-life situations during the first half of the twentieth century that the press photographer Gunnar Lundh found interesting. By pressing the shutter button on his camera, Lundh captured the reflections of the light inside his machine. Considering the camera body as context, the motifs were in an in-between pause; maybe this time the photographer had captured the perfect image, or maybe he failed to adjust the camera settings? The context changed again as the film rolls entered the photographic laboratory where, through the magic process of developing, two-dimensional images were integrated with three-dimensional papers, resulting in the physical presence of photographs. These (and their negative counterparts) were then incorporated into the archive of Lundh's image agency as glimpses of everyday life in twentieth century Sweden. 
In the image agency's commercial context, the images became commodities, ready to tell - and sell-their stories if an editor or journalist found them worth buying.

The context changed in a crucial way in 1961 when the archive was donated to the Nordic Museum in Stockholm. The move through space also meant a change in cultural value: the collection entered the realm of authorised heritage. In other words, the photographs became assets in a museum's production of knowledge about what history we share (Becker 1992). It is worthwhile to reflect on all of the contexts mentioned above when using historic photographs as sources of ethnographic knowledge.

The Lundh collection comprises more than 300000 individual photographs. The corpus covers the period from the early 1920 s to the late 1950s. The national context is Sweden, but there are also photographs from other European countries such as Denmark and Germany. Today, the Lundh collection constitutes approximately one-fifth of the Nordic Museum's total photographic collection. The collection is characterized by heterogeneity in its motifs, reflecting both topics that interested Lundh personally and motifs he thought he could sell within a media context.

One purpose of Images and Stories of Everyday Life, the umbrella project in which this essay is produced, has been to digitise a considerable amount of Lundh's photographs. Therefore, the lion's share of the photographs was initially scanned at low resolution and the seven researchers involved were asked to select motifs based on their respective research interests. The selected pictures were scanned in a higher quality and published online. The idea behind this procedure was that each researcher would produce valid and serviceable metadata guided by his or her own scholarly expertise.

Being an ethnologist who uses qualitative methods, one issue for me was to address such a massive and varied corpus of pictures as presented by the Lundh collection. As I skimmed through all the pictures, I noticed that funerals were, if not frequent, at least a regular feature in the collection. Based on this observation, the choice was made to let my scholarly interest in social and cultural constructions around death govern the selection process. ${ }^{1}$ My answer to the project's call to select photos thus resulted in a selection of pictures of funerals and burial ceremonies, totalling just under 500 pictures from approximately 30 events. It is from this sample that photographs of three funerals were chosen for this essay. The analyses of the three cases will be presented in turn. Each example begins with a description of the sample of photographs and a review of what the images represent, followed by my reflections and lines of thought throughout the analysis. 


\section{Close Reading of Silent Talking Contexts}

Eighteen pictures of a funeral. Five of them in a church environment and nine of a grave covered in flowers. Four depict people in dark clothes. What story can the pictures tell? The objective in this example is to demonstrate how a narrow reading can uncover new, unexpected clues, which in turn may reveal layers of articulations in otherwise apparently silent photographs. Let us start with the photos of the coffin in the church.

One shows flower bouquets and wreaths arranged on top of, and in front of a coffin or placed on either side of it along the walls. White ribbons are hanging from some wreaths, but it is not possible to see what they say. The blurry head of a person standing behind the coffin, and wearing a black top hat is visible in one picture. The focus of the camera has not been adjusted properly.

I saw that the photos depicted a funeral. Yet, they seemed difficult to interpret: who was dead, who was mourning, and what should the observer think about it? There were no crying eyes, no wet handkerchiefs, no bowed heads, and no one to identify with. The man behind the coffin appeared almost like a ghost due to the blurry quality of the photo. Despite the emotive motif, the pictures appeared bland, or visually silent. They did not speak to me. However, a photograph is not only an image but also a material object. A photograph in an archive is more than a singular physical thing; it is an object in a particular context. In this example, the contiguous context was a so-called contact sheet on which the photograph was mounted. On the cardboard sheet there was an ornate handwriting reading "Gunnar Lundh's mother's funeral in Höganäs church".

The note added information; the pictures were shot in a church in Höganäs in the south of Sweden. However, it also said something about the social context: the photographer and the person being buried were mother and son. With this knowledge, the visual elements and the poor technical quality started to speak to each other. Even though the contours and content were the same, I read them in new ways. For example, I saw the blurriness as an expression of an emotionally affected photographer. The unengaged composition made me reflect on the touching aspects of a man taking photographs at his mother's funeral.

Taking a self-reflective perspective, I noticed that my gaze changed when I became acquainted with the social context of the situation. I started to look at the pictures as if they were part of a family album, instead of the museum's archive. Family photo albums are about emotional communication and can reflect individual ways of grasping and handling challenges in life (Sandbye 2014, see also Dahlgren 2013 and Batchen 2008). My new, more personalized gaze allowed me to read between the lines.

This kind of personal reading may seem academically unconventional. However, Lundh's business was rather small. Apart from occasional assistants, he 


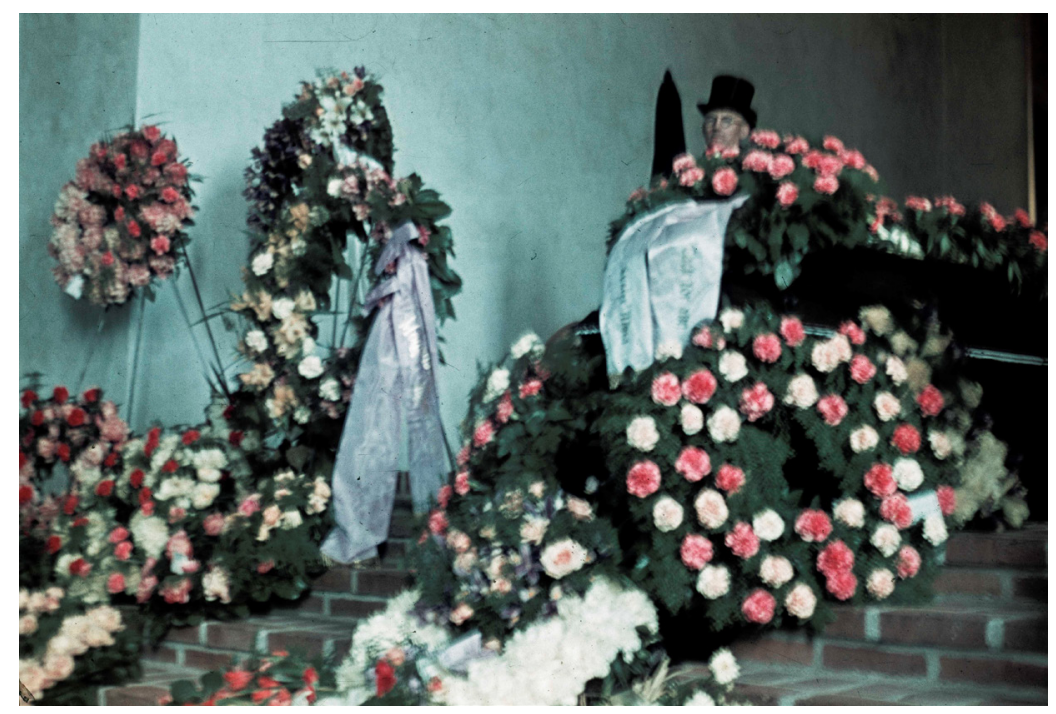

Fig. 1 Photo Gunnar Lundh (NMA.0045731).

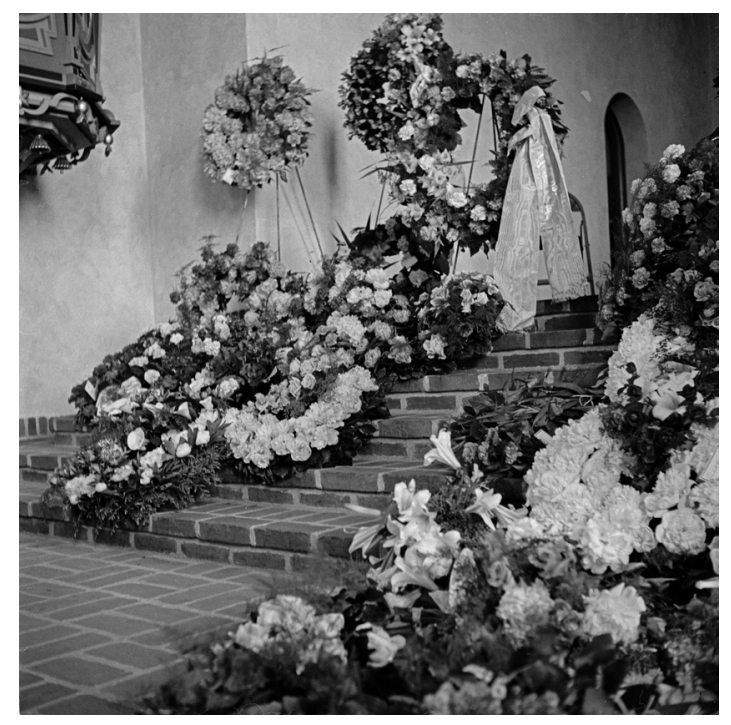

Fig. 2 Photo Gunnar Lundh (NMA.0094381).

took care of the business himself-eventually together with his wife, and stored all copies and negatives at home. The indexical relation between the auteur and his work was utterly robust, and my intimate interpretation seemed to allow for a new understanding of the material. On the other hand, these were not photographs in a private family photo album but, rather, official records in the museum's archive. 


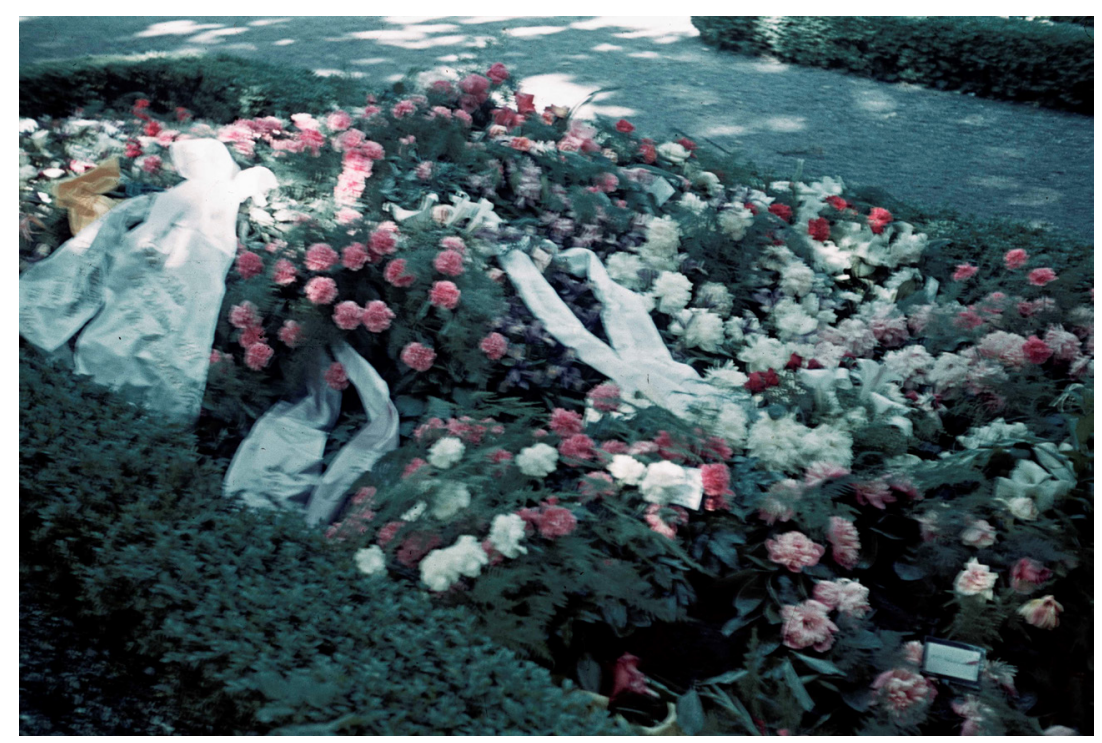

Fig. 3 Photo Gunnar Lundh (NMA.0045742).

As such sources, they reached further than the individual creator, representing not only Lundh but also the official memory of the institution. This called for a distant and critical perspective in the analysis.

The two ways of approaching the photographs may seem incompatible. The answer was to oscillate between the two perspectives and let the knowledge of the personal context highlight the universal side of the situation, and vice versa. By allowing myself to become emotionally engaged, the affective qualities made the photos generally interesting as micro-historic sources. Put differently, allowing a personal relationship between the photographer and the photographed to be included in the analysis made the blurred images tell a story.

As a consequence of including the photographs from Lundh's mother's funeral in this article, they have been published on the internet through the umbrella project. They are now generally accessible, and through the museum's work, information is linked to the pictures to explain the context. However, the detail that made me see the pictures in a new light will not be accessible to online viewers; the expressive handwriting will stay on the contact sheet.

\section{Symbols that Scream Versus Silences that Speak}

What I perceived as a visual silence in this next example was the contrast between a highly politically laden occasion and the evidently modest documentation of it. While the other funerals were often documented in many photos, there was only 
a single picture. The motif is the interior of a church, taken from a bird's-eye-view. The spectator looks down at a hall where a service is taking place. You see the church's quatrefoil choir window, a chandelier, and small birch trees along the walls. Constituting the centre of the photograph is a coffin. On each side are three candlesticks with burning candles. People are sitting on the church benches. Five people are standing up, two on each side of the coffin and one at the end of it, each one holding a banner. However, what made me inspect the picture more thoroughly was the draping of the coffin. A cloth with a large swastika, the Nazi symbol, was covering it.

I found only one shot from this occasion. However, like the other photos, this photo is mounted on a contact sheet. Nine photos show interiors from what might be Lundh's apartment, which also functioned as his office and lab. Five include people performing work-related practices. One photo represents a flower pot in a window, another the exterior of a white house on a snowy street. It is a rather odd collection of motifs. The sheet is marked with the year 1934. There are some handwritten notes: at the top it says "Gunnar Lundh's laboratory", and to the right, "Stockholm". Under two pictures, the initials "G.L." (Gunnar Lundh?) and the names "R. Hallin" and "Flodin" are found. On the one hand, this solitary funeral photo could easily have been overlooked. On the other hand, the symbol on the coffin cried out as a punctum (Barthes 1993). What appeared to me as visual silences, were firstly the fact that there was only one picture of this occasion, and secondly that the picture with the symbol of a swastika was presented without comment.

My initial thought was that the photos on the sheet were shot in chronological order during one day. Following this hypothesis, Lundh would have shot some working scenes in the morning, then documented the funeral, taking a photo of the white house in passing. Back at the office in the afternoon, he would have continued to work with the working scenes and eventually shot the photo of a plant in a pot. I scratched my head, as I tried to find the logic in the photographs.

However, according to a colleague ${ }^{2}$, the photos were probably taken at different times and places. Due to my knowledge that Lundh had accompanied the Women's Section of the Social Democratic Party on a trip to Germany during winter 1934, I tried the hypothesis that the photo was shot in Germany. As a consequence of changing the national context, the Nazi symbol did not appear as piercing as before. In 1933, the flag with the swastika had become the national flag of Germany, and had a double meaning, representing both the Nazi party in Germany and the German nation state.

My initial encounter was with a small photo glued to a contact sheet. When it was scanned at high resolution, it became possible to read Swedish words on the banners, pointing towards a Swedish context after all. My attentive colleague offered a new theory: maybe it was the remains of Carin Göring, the late wife 


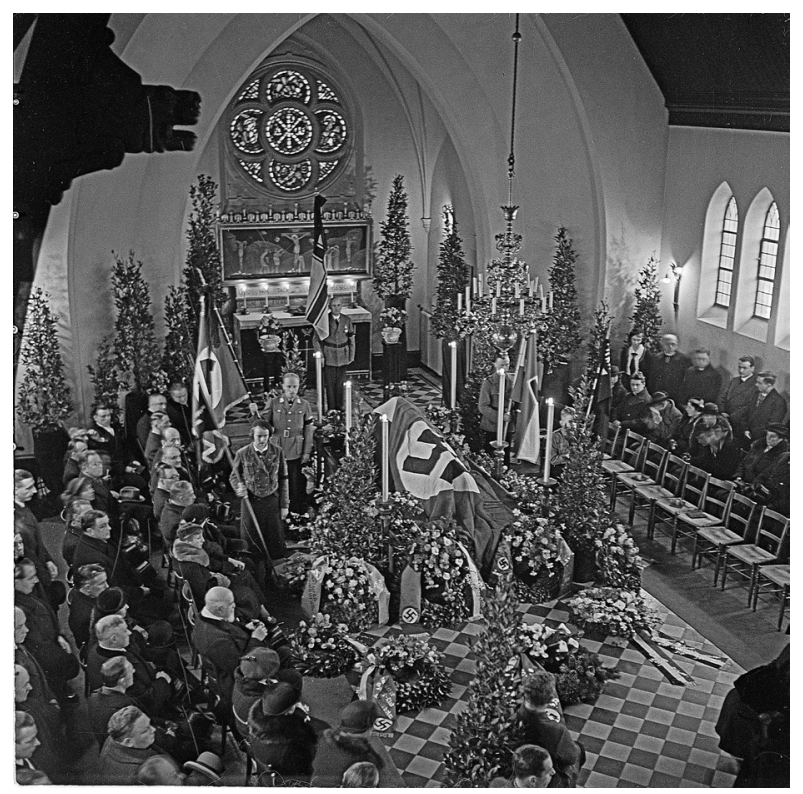

Fig 4. Photo: Gunnar Lundh (NMA.0094380).

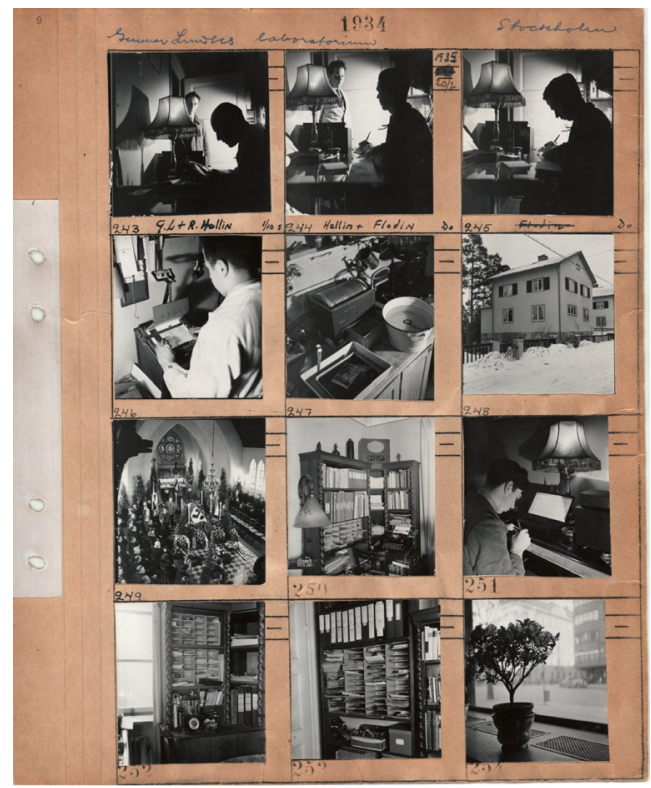

Fig. 5 Photo Gunnar Lundh (NMA.0082523).

of Herman Göring, commander-in-chief of the German air force, the Luftwaffe, inside the coffin. ${ }^{3}$ The theory was supported by the year, the Nazi symbols and the official character of the ceremony, but most of all by the suspicion that the location 
was Oscars Lillkyrka (Oscar's Church) in central Stockholm, located in the same neighbourhood as Carin Göring's family.

If the theory was correct, the photo could alter the historiography of Sweden's Nazi connections before the war. It would perhaps be possible to identify politicians or other high-ranking individuals attending the ceremony. The new circumstances led to an increased eagerness to know more. A first step was to identify the location, and, keen on getting a result, I rapidly consulted colleagues with competence in architecture. After a while, the conclusion was that the photo was shot in Sandsborg Chapel at Sandsborg Cemetery, located a few kilometres south of Stockholm. ${ }^{4}$

This new and solid information did not support the Göring hypothesis. It is unlikely that such a high-profile ceremony would have been conducted outside Stockholm at a place with no connection to the deceased, and I found no other information about any ceremony taking place in Sweden backing the theory. ${ }^{5}$ With this information, my interest in the photo declined. It is worthwhile to linger on my own fluctuating interest in the photo. What I saw at first was a photo of a funeral ceremony (of which I had seen quite a few by Lundh) with a detail that struck me as provocative. The thing that stood out, of course, was the swastika.

When I first placed the photo in a Swedish context, it roused my attention. The assumption that the photo was shot in Germany made the interest fade. When it then seemed as the picture was shot in Sweden after all, it started to tease my mind once more. When the connection to Göring came up, I even engaged several colleagues in the process of identifying the site. My interest faded again when the Göring connection seemed to be too flimsy to be taken seriously. Taking a reflexive stance, I recognize that the presumptive connection to high politics made me a bit too enthusiastic, and I missed the crucial point that Lundh put this photograph side by side with photos of everyday situations such as work in the laboratory, a house in the street and a flower pot.

Lundh did not mark or comment on the photo. This suggests that neither the swastika nor Nazism stood out as remarkable to him. Lundh had been working in Berlin (without expressing any sympathy for the Nazi party or ideology) and had most likely encountered the symbol in various contexts. In Sweden, Nazi sympathies were growing: two years after the date of the photo, the Nazi party was at its height in Sweden and received over one hundred mandates in the municipal elections (Lööw 2004: 244). Nazi ideology was part of political life, at least at a regional level in Sweden at the time (ibid: 9). As a whole, Lundh's archive reflects this: visual representations of Nazism are regular features in the collection.

However, the analytical potential of photos representing Nazi symbols is not that they prove the presence of Nazi ideology in Sweden at the time, but rather 
that the expression of Nazism was a banal element to the auteur. Therefore, it is crucial to comprehend the silence surrounding the photo of the Nazi funeral as a historic source in its own right. This kind of visual silence reflects a society in which Nazi ideology was taken as an ordinary component. This interpretation was lost in the enthusiasm over a chance to place an unknown piece into the historic puzzle.

The swastika was not an innocent symbol at the time; the Nazi ideology was available to be read, even if the symbol had not yet been charged with the crimes committed by the Nazi regime in the subsequent decade. A lesson to be learned from this example is that destructive or totalitarian regimes do not advertise in advance. Once again, the potential is in the contexts: it is in relation to other photos that the silence can be identified, and this can only happen if the contact sheet is kept intact. This will be a challenge in the process of digitalization, where each photo is scanned as an individual image; a person who comes across the photo online will not see it side by side with a flower pot and an average house in the street.

\section{Contemporary Silence of Historic Media Noise}

The photos of the third funeral contrast with the two others concerning milieu and number. There are also many other sources for the same event, which makes it interesting to reflect upon what silences that are re-produced. There are more than 60 photos shot in a couple of sequences. I will briefly account for them in the chronological order in which I presume they were shot.

Three photos show a parade of more than 50 people in black coats and top hats. The next few shots capture black cars sequentially parking outside a massive entrance of what appears to be a church. Even if none of the pictures capture the whole building, the church in question appears to be impressive. One picture shows a row of flagpoles with flags at half-mast. The weather is cloudy, and there are patches of snow on the ground.

Another suite of photos shows a coffin being carried out from the entrance. The bearers are men in military uniforms. Men wearing dark overcoats and top hats appear to assist them. Spruce branches cover the ground next to a small wooden staircase placed in front of a catafalque. A number of uniformed mensoldiers-wearing tall fur caps are standing in rows, at attention, rifles with bayonets pointing straight up. The camera's eye is directed towards the coffin, and when the catafalque eventually leaves, the viewer can follow it as it disappears between impressive façades that a Stockholm native would recognize as the Royal Castle in Stockholm. Behind the uniformed guards, several attendees carry still or movie cameras. More photos show people emerging from the entrance and getting 


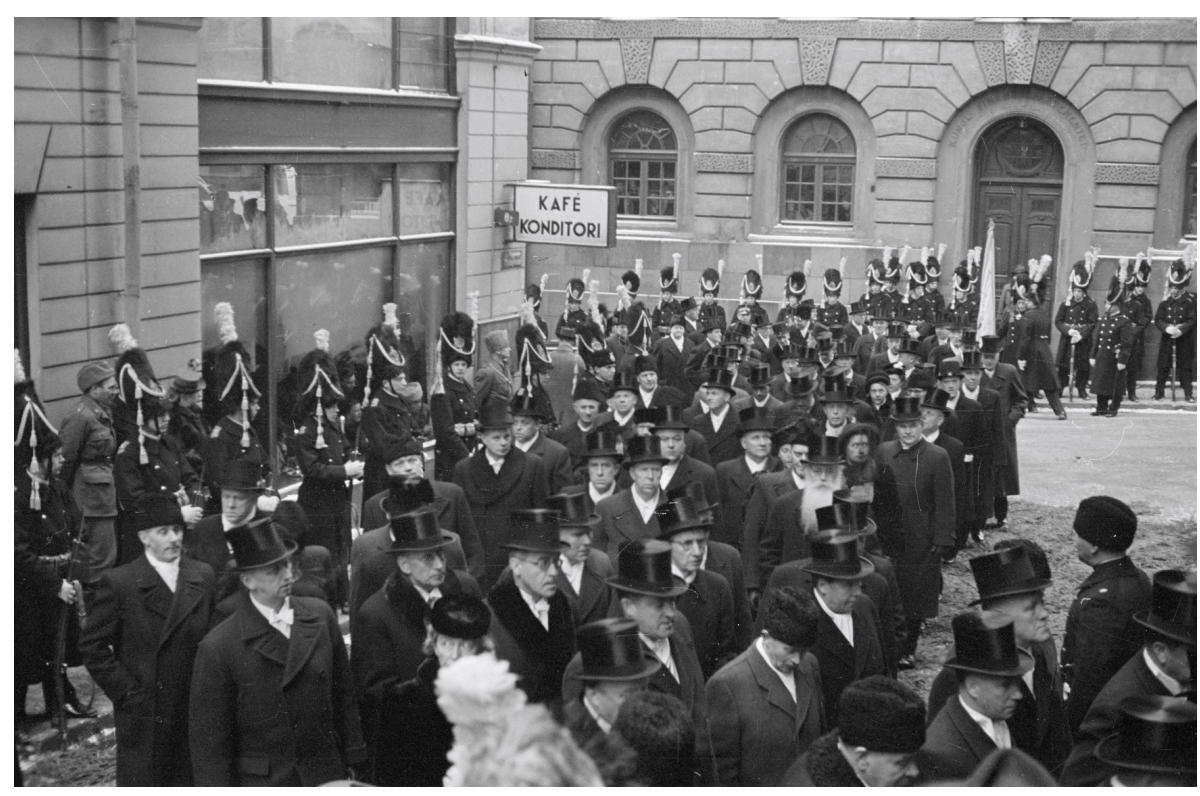

Fig. 6 Photo: Gunnar Lundh (NMA.0094382).

into a black car. Those familiar with the Swedish royal family will recognize Gustaf Adolf, who was the crown prince of Sweden at the time (eventually king Gustav VI Adolf). The woman by his side is harder to recognize; a mourning veil covers her face. Given the situation, it is most likely the crown prince's wife Louise. Another picture captures three young girls walking down the stairs, followed by an older woman. These are three of the four princesses with their, at the time well known, nursemaid Ingrid "Nenne" Björnberg. The fourth sister and their little brother, Carl Gustaf, are absent.

Another sequence depicts six horses pulling the catafalque through a street lined with people. In the same series, a long cortège of black motor cars is eventually visible. People have gathered in the streets. However, despite the crowded pavement, the impression is that all is quiet and disciplined. In contrast to the other two funerals, this one is easily put into its historical context. It is the funeral of an official person in Sweden, Prince Gustav Adolf (not to be mistaken for his father and namesake, Prince Gustav Adolf, mentioned above), the father of the present King Carl XVI Gustaf (who is the princesses' little brother, also mentioned above). The death of the prince was unexpected; he was killed in an airplane crash on January 26 in Copenhagen. He had a state funeral. The church in the photo is Storkyrkan, the Great Church, in Stockholm. The year was 1947.

The royal funeral was an official occasion and of great public interest. It thus constituted what Dayan and Katz call a media event (1992). A media event is organized with a high degree of consideration for the needs of the media. First, journalists and photographers (still, film and broadcast) are guaranteed good 


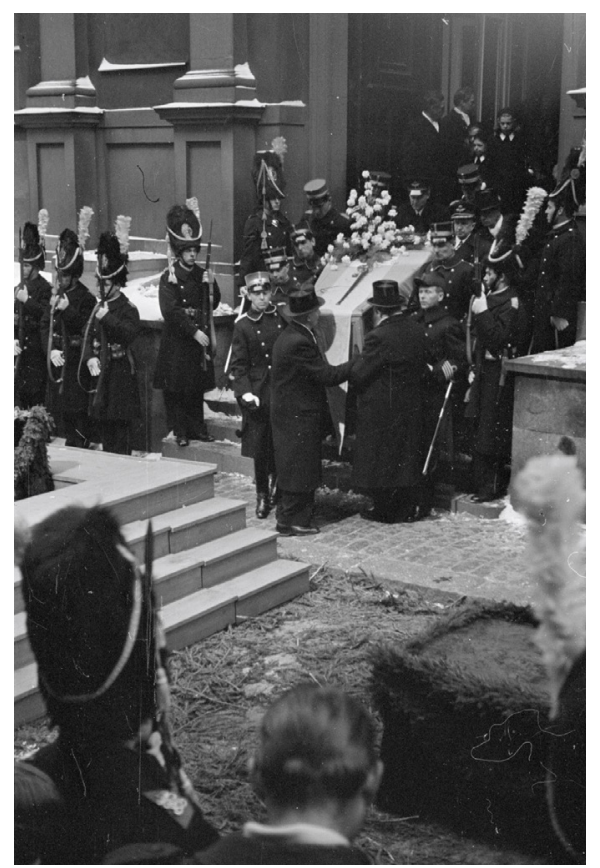

Fig 7. Photo: Gunnar Lundh (NMA.0094382).

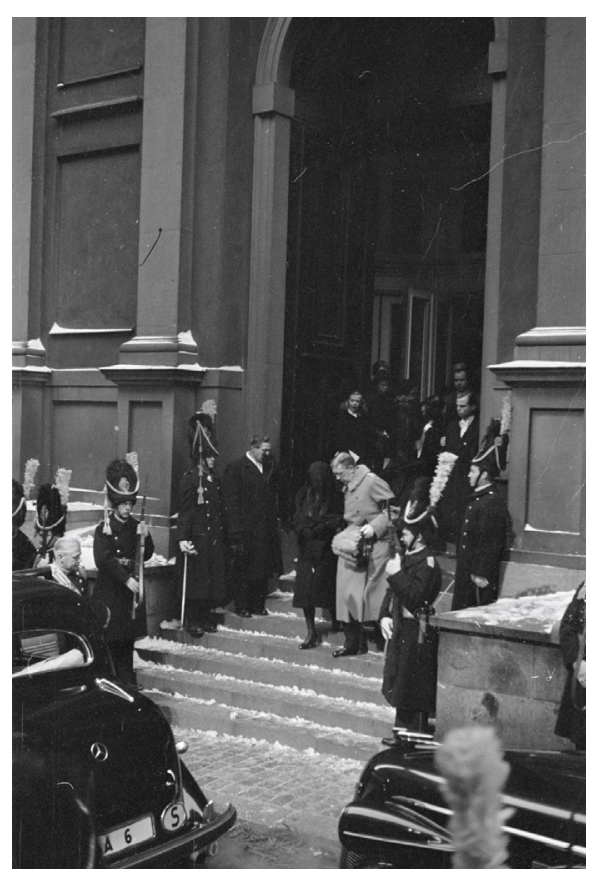

Fig. 8 Photo: Gunnar Lundh (NMA.0094382).

views. Second, media events are designed to be as photogenic as possible. Third, the activities are organized at a time for the best possible medial dramaturgy. One of Dayan and Katz's arguments is that the recognizable script creates a sense of redundancy, and the audience identifies the event as something important.

Scrutinizing the photos from the prince's funeral, the contours of the media event are recognized. The photos are shot from a close and elevated location, giving full visual access to the entrance of the church (my guess is that other press photographers are standing in the same spot as Lundh). The stairs to the church serve as a stage where various prominent people are put on display for the best photogenic scene. Every viewer familiar with societal hierarchies and the repertoire of funerals will understand that this is a funeral of a significant person. The short, predetermined path frames the event as important and sorts the participants by rank; some are watching, while others are being watched. The social ranking is documented and reproduced in Lundh's photographs.

It has been argued that one of Lundh's qualities as a press photographer was in capturing unspoiled extracts from ordinary people's everyday lives giving otherwise unheard voices an opportunity to speak (see, for example, the contributions of Steinrud, Bäckman, Hörnfeldt and Larsson to this issue of Cultural Unbound). Lundh's interest in the everyday offers insight into ordinary 


\section{Culture Unbound}

Journal of Current Cultural Research

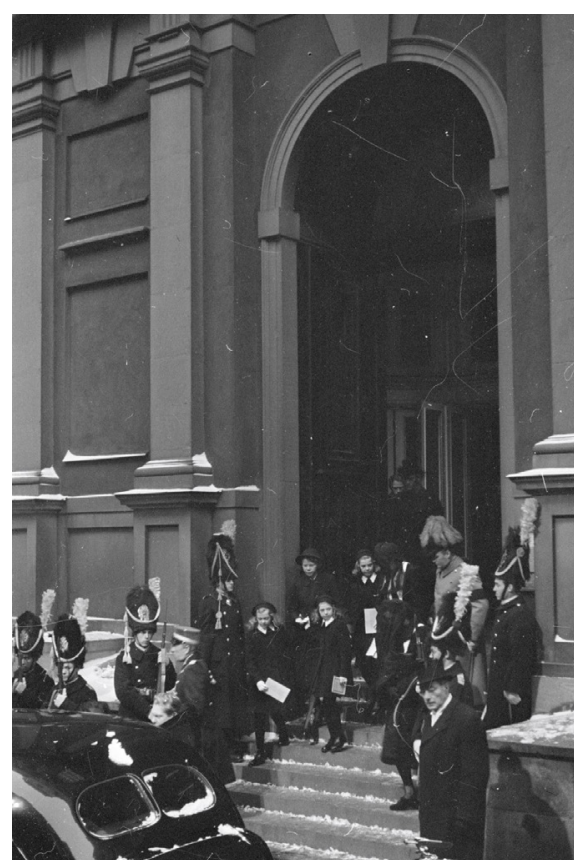

Fig. 9 Photo: Gunnar Lundh (NMA.0094382).

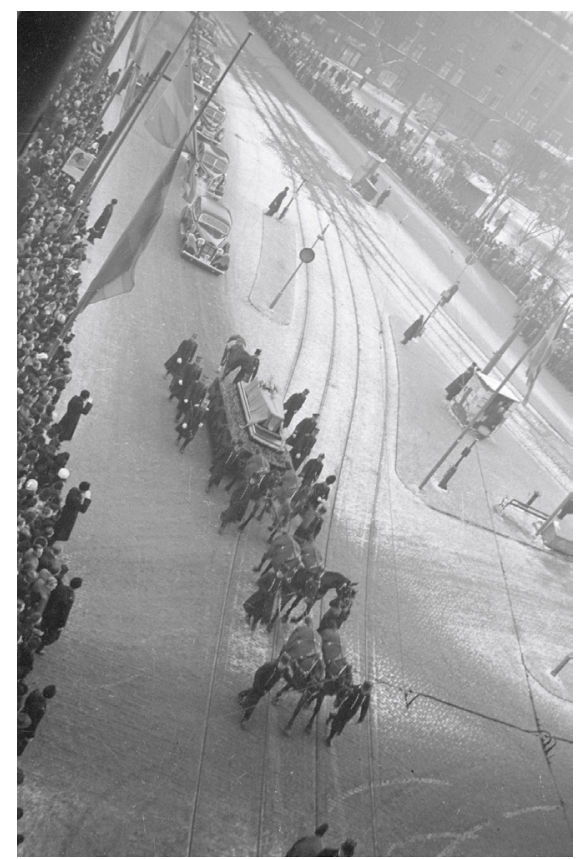

Fig. 10 Photo: Gunnar Lundh (NMA.0094382).

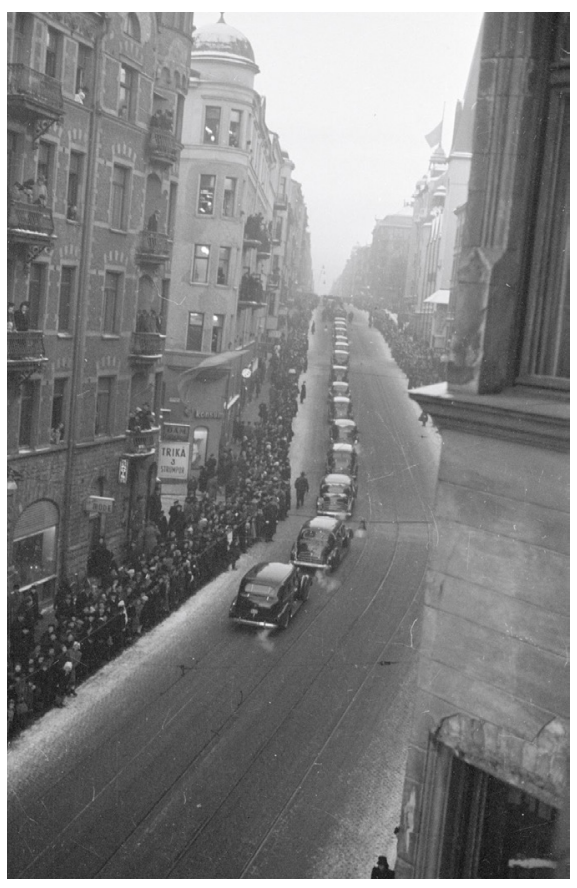

Fig. 11 Photo: Gunnar Lundh (NMA.0094382). 
people's lives, otherwise absent from historical records. This documentation, on the other hand, echoes official historiography more than it contributes to a new understanding of the past. Documenting the royal funeral, Lund is captured by the logic of the media event. The pictures join in a symphony that is orchestrated by the those in power and thus silences other narratives.

In the archive, this photographic suite belongs to the same genre as the photos of the funerals of other prominent individuals, such as Archbishop Nathan Söderblom in 1931; the former Prime Minister and Marshal of the Realm, Oscar von Sydow, in 1931; Prince Eugene in 1947; and two famous actors, Gösta Ekman in 1938 and Anders de Wahl in 1956. The effect of the digitalization of photographs representing well-known historic events is hard to evaluate. In the case of the funeral of Prince Gustav Adolf, as with the other funerals of prominent persons, a qualified guess is that these will reach an interested audience and, as a kind of resonance, strengthen an already established historical narrative.

\section{Concluding Reflections}

In examining Gunnar Lundh's archive, I have treated photographs not as nouns but as verbs, as entities that do something. One conclusion is that visual silence is neither absolute nor predictable. The blurry photos in the first example were silent until the intimate context became clear to me, then the technical and artistic shortcomings started to convey information. The silence of the lonely photo of the Nazi funeral in the second example turned out to be an important resource in its own right. The last example illustrated how a massive amount of information can compose a dominant narrative that silences other narratives.

A final meta-reflection can be included. The large amount of digitized images published online through this project will generate new stories about the period when Gunnar Lundh was active. There has been considerable discussion about the consequences of digitalization in relation to the responsibility of heritage institutions. One side points to a democratic aspect of digitalization with the photos becoming available to an infinite number of people. The more sceptic side points out ethical issues and copyright issues, among other things.

Nonetheless, there seems to be an agreement that when something is digitized and published online, the original institution loses control. However, losing control does not necessarily mean that knowledge production decreases. Cecila Strandroth has shown how unnoticed photos in the archive suddenly gained a great amount of interest when published online. Previously anonymous photos began to be downloaded and discussed, adding both knowledge and context to the photos (2012: 109ff). 
Digitization can open up new ways of understanding historic photographs. However, reflecting on the examples in the article, it may also underpin representational biases instead of challenging them (see for example Taylor \& Gibson 2017). Pictures from a royal funeral might find a wide audience, since the narrative is already part of a collective memory. Photos representing an anonymous funeral may fade away into a collective amnesia.

A picture is worth a thousand words. By offering a multitude of pictures of everyday life as seen through the eyes of Gunnar Lundh, hopefully the project Images and stories of everyday life will contribute to a nuanced conception of the past. However, what narratives and whose memories that may fade away in the process is impossible to say in advance. There is the oft-quoted saying by Søren Kierkegaard, that life can only be understood backwards, but it has to be lived forwards (Kierkegaard 1843). The same principle goes for a research project: first you have to do it, then you can evaluate it. If nothing else, the variety and number of motifs remind us that the past is neither a single nor a coherent story but rather a whirlwind of different destinies with individual joys and sorrows.

Mattias Frihammar is an ethnologist at the Department of Ethnology, History of Religion and Gender Studies (ERG) at Stockholm University. He is initiator of the Critical Heritage Studies Network at Stockholm University and coordinator of the Bachelors Program in Museum and Heritage Studies at Stockholm University. He is currently involved in the research project Making a Military Heritage: Gender and Nation in Sweden's Cold War History. This article is part of the project Images and Stories of Everyday Life (Vardagens bilder och berättelser), financed by The Royal Swedish Academy of Letters, History and Antiquities, and The Swedish Foundation for Humanities and Social Sciences. Email: mattias.frihammar@ etnologi.su.se

\section{Notes}

1The choice of motifs can be said to be analytically motivated, as the practices around death mirror a society's cultural structure (Durkheim 1915). However, the main point is the universality of death. Death concerns, affects and strikes everyone. Everybody will eventually die, regardless of gender, class or race. A sample of funeral photos therefore opens up a discussion about what identities will become part of a collective memory. Everybody dies, but whose deaths are remembered? Whose deaths are left in silence?

2 An important person for my research process in this project, and for the research project as a whole, is the photographer Per J. Larsson. Larsson has been in charge of scanning the photographs of Gunnar Lundh. Larsson has become very familiar 


\section{Culture Unbound}

Journal of Current Cultural Research

with the collection and has a comprehensive view of Lundh's work, which has been of great value to the researchers. Larsson has also contributed reflections and forward-looking proposals on how to understand the collection throughout the project. Among other things, it was Larsson who informed me of the fact that Lundh sometimes collected motifs from different occasions on the same contact sheet and identified the funeral with the Swastika as having taken place in Sweden. 3 Carin Göring died on October 17, 1931 and was buried outside Stockholm at Lovön. After her death, Göring built a hunting lodge in Germany called Carinhall in honour of his late wife, and in the beginning of summer 1934, Carin's remains were moved from Lovön in Sweden to Carinhall in Germany.

4 Thank to Fredrik Krohn Andersson and Peter Gillgren for helping me identify the chapel.

5 In Germany, on the other hand, the funeral of Carin Göring was arranged in a statesmanlike manner and broadly broadcasted by the Nazi propaganda, with prominent Nazi leaders, including Hitler, participating in the parades and ceremonies.

\section{References}

Barthes, Roland (1993): Camera Lucida: reflections on photography. London: Vintage.

Batchen, Geoffrey, (2008): “Snapshots”, Photographies 1, 2: 124, 121-142.

Becker, Karin (1992): "Picturing our past. An Archive Constructs a National Culture", The Journal of American Folklore, 105: 415, pp. 3-18.

Burke, Peter (2001): Eyewitnessing: the uses of images as historical evidence. Ithaca, N.Y.: Cornell University Press.

Dahlgren, Anna (2013): Ett medium för visuell bildning: kulturhistoriska perspektiv på fotoalbum 1850-1950. Göteborg: Makadam.

Durkheim, Émile (1952): Suicide. London: Routledge and Kegan Paul.

Dayan, Daniel \& Katz, Elihu (1992): Media events: the live broadcasting of history. Cambridge, Mass.: Harvard University Press.

Kirkegaard, Søren (1848): Journals IV 164

Lööw, Heléne (2004). Nazismen i Sverige 1924-1979: pionjärerna, partierna, propagandan. Stockholm: Ordfront.

Manson, Rhiannon \& Sayner, Joanne (2018): Bringing museal silences into focus: eight ways of thinking, International Journal of Heritage Studies. 10: 1, 1-16.

Sandbye, Mette (2014): "Looking at the family album: a resumed theoretical discussion of why and how", Journal of Aesthetics \& Culture, 6: 1, 1-16.

Sekula, Allan (2003): "Reading an archive. Photography between labour and capital", Liz Wells (ed.) The photography reader, London: Routledge, 443-452.

Strandroth, Cecilia (2009): "Pà resande fot i det digitala bildarkivet: ett brukarperspektiv," Pelle Snickars \& Anna Dahlgren (eds), I bildarkivet: om fotografi och digitaliseringens effekter, Stockholm: Kungl. Biblioteket, 91-120.

Taylor, Joel, and Laura Kate Gibson (2017): "Digitization, Digital Interaction and Social Media: Embedded Barriers to Democratic Heritage." International Journal of Heritage Studies 23: 5, 1-13. 